\title{
CHLOROFLUOROCARBONS, SULFUR HEXAFLUORIDE, AND DISSOLVED PERMANENT GASES IN GROUND WATER FROM SELECTED SITES IN AND NEAR THE IDAHO NATIONAL ENGINEERING AND ENVIRONMENTAL LABORATORY, IDAHO, 1994-97
}

U.S. GEOLOGICAL SURVEY OPEN-FILE REPORT 98-274 


\section{CHLOROFLUOROCARBONS, SULFUR HEXAFLUORIDE, AND DISSOLVED PERMANENT GASES IN GROUND WATER FROM SELECTED SITES IN AND NEAR THE IDAHO NATIONAL ENGINEERING AND ENVIRONMENTAL LABORATORY, IDAHO, 1994-97}

By: Eurybiades Busenberg, L. Niel Plummer, Roy C. Bartholomay, and Julian E. Wayland

U. S. Geological Survey

Open-File Report 98-274

Prepared in cooperation with the

U.S. DEPARTMENT OF ENERGY 


\section{DEPARTMENT OF THE INTERIOR \\ BRUCE BABBITT, Secretary}

\section{U.S. GEOLOGICAL SURVEY}

Thomas J. Casadevall, Acting Director

Any use of trade, product, or firm names is for descriptive purposes

only and does not imply endorsement by the U.S. Government.

For additional information write to:

U.S. Geological Survey

INEEL, MS 1160

P.O. Box 2230

Idaho Falls, ID 83403-2230
Copies of this report can be purchased from:

U.S. Geological Survey

Information Services

Box 25286, Federal Center

Denver, CO 80225 


\section{CONTENTS}

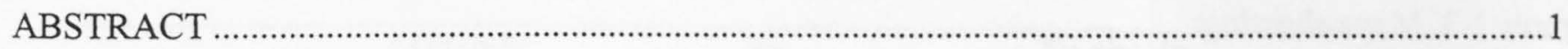

INTRODUCTION

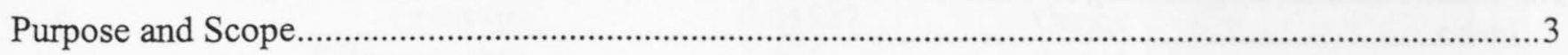

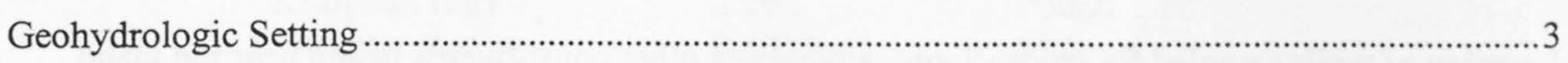

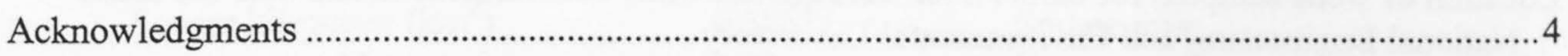

METHODS OF STUDY …………………………………………………………………………

METHODS FOR THE COLLECTION AND ANALYSIS OF GROUND WATER FOR CHLOROFLUOROCARBONS AND OTHER VOLATILE ORGANIC COMPOUNDS AND

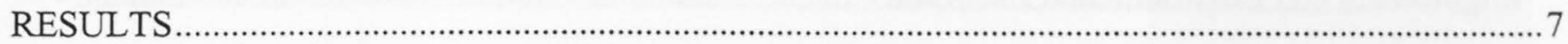

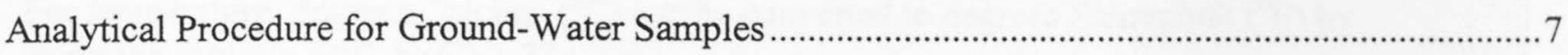

Calibration of the Chlorofluorocarbon Analytical System ............................................................... 8

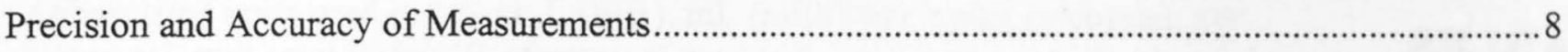

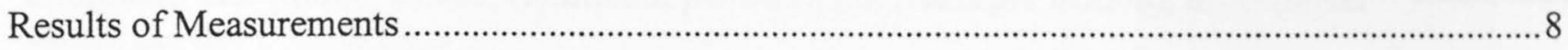

METHODS FOR THE COLLECTION AND ANALYSIS OF GROUND WATER FOR SULFUR

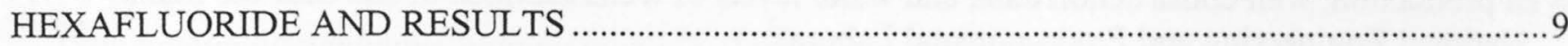

Vacuum Extraction of Sulfur Hexafluoride from Ground Water ........................................................ 9

Headspace Gas Extraction of Sulfur Hexafluoride from Water ........................................................ 10

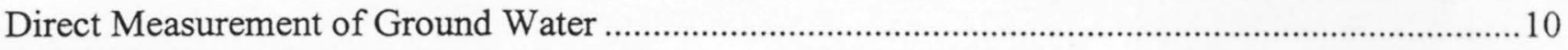

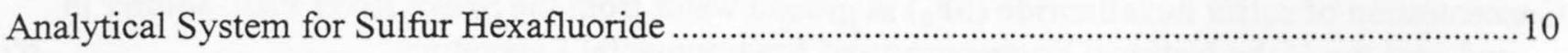

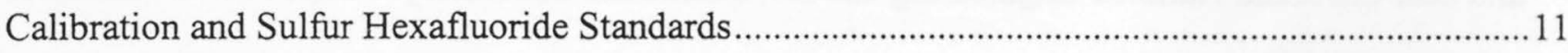

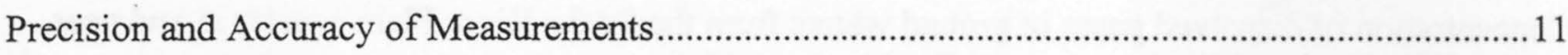

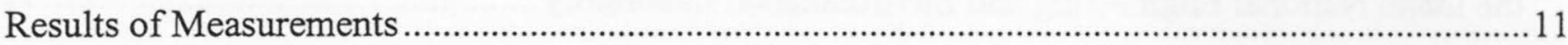

METHODS FOR THE COLLECTION AND ANALYSIS OF GROUND WATER FOR NITROGEN, OXYGEN, ARGON, CARBON DIOXIDE, METHANE, AND RESULTS ………...........................12

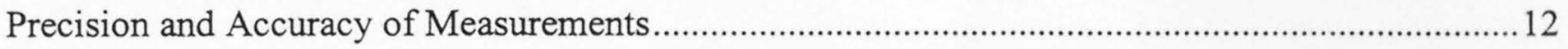

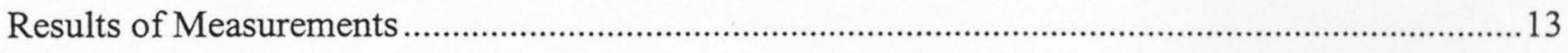

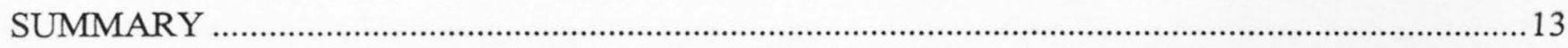

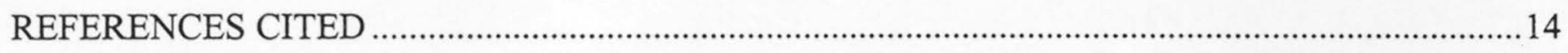

APPENDIX A

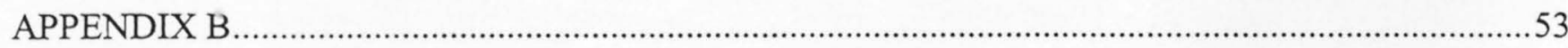

APPENDIX C 


\section{FIGURES}

Figures 1-3. Maps showing:

1. The Idaho National Engineering and Environmental Laboratory, and selected facilities, southeastern

Idaho.

2. Location of wells sampled for chlorofluorocarbons and other constitiuents in and near the Idaho National Engineering and Environmental Laboratory

3. Location of wells sampled for chlorofluorocarbons and other constituents, Test Reactor Area, Idaho

Chemical Processing Pant, and Radioactive Waste Management Complex in the Idaho National

Engineering and Environmental Laboratory.....

\section{TABLES}

1. Well production, well construction data, and water levels of wells sampled in and near the Idaho National Engineering and Environmental Laboratory.

2. Concentration of chlorofluorocarbons in ground water in and near the Idaho National Engineering and Environmental Laboratory

3. Concentration of sulfur hexafluoride $\left(\mathrm{SF}_{6}\right)$ in ground water from the Snake River Plain aquifer in and near the Idaho National Engineering and Environmental Laboratory

4. Concentration of dissolved gases in ground waters from the Snake River Plain aquifer in and near the Idaho National Engineering and Environmental Laboratory 


\section{CONVERSION FACTORS AND ABBREVIATED UNITS}

\begin{tabular}{rll}
\hline Multiply & By & To obtain \\
\hline Cubic centimeters $\left(\mathrm{cm}^{3}\right)$ & 0.06102 & Cubic inch \\
Gram $(\mathrm{g})$ & 0.03527 & Ounce \\
Kilogram $(\mathrm{kg})$ & 2.205 & Pound \\
Kilometer $(\mathrm{km})$ & 0.6215 & Mile \\
Meter $(\mathrm{m})$ & 0.3861 & Square mile \\
Square kilometer $\left(\mathrm{km}^{2}\right)$ & 3.281 & Foot \\
Millimeter $(\mathrm{mm})$ & 0.03937 & Inch \\
Becquerel per liter $(\mathrm{Bq} / \mathrm{L})$ & 0.027 & Picocuries per liter \\
Terrabecquerel $(\mathrm{TBq})$ & 27 & Curries \\
\hline
\end{tabular}

For temperature, degrees Celcius $\left({ }^{\circ} \mathrm{C}\right)$ can be converted to degrees Fahrenheit $\left({ }^{\circ} \mathrm{F}\right)$ by using the formula $\mathrm{F}=(1.8)(\mathrm{C})+32$.

Abbreviated units used in report: $\mathrm{L}$ (liter), $\mathrm{mL}$ (milliliter), $\mathrm{pg} / \mathrm{kg}$ (picogram per kilogram), mol (mole), fmol/L (femtomol per liter), ppt (parts per trillion), $\mathrm{m}^{2} / \mathrm{d}$ (meter square per day). 



\title{
Chlorofluorocarbons, sulfur hexafluoride, and dissolved permanent gases in ground water from selected sites in and near the Idaho National Engineering and Environmental Laboratory, Idaho, 1994-97
}

\author{
By Eurybiades Busenberg, L. N. Plummer, Roy C. Bartholomay, and Julian E. Wayland
}

\begin{abstract}
From July 1994 through May 1997, the U.S. Geological Survey in cooperation with the Department of Energy, sampled 86 wells completed in the Snake River Plain aquifer at and near the Idaho National Engineering and Environmental Laboratory (INEEL). The wells were sampled for a variety of constituents including one- and two-carbon halocarbons. Concentrations of dichlorodifluoromethane (CFC-12), trichlorofluoromethane (CFC-11), and trichlorotrifluororoethane (CFC-113) were determined. The samples for halocarbon analysis were collected in 62-milliliter flame sealed borosilicate glass ampoules in the field. The data will be used to evaluate the ages of ground waters at INEEL. The ages of the ground water will be used to determine recharge rates, residence time, and travel time of water in the Snake River Plain aquifer in and near INEEL. The chromatograms of 139 ground waters are presented showing a large number of halomethanes, haloethanes, and haloethenes present in the ground waters underlying the INEEL. The chromatograms can be used to qualitatively evaluate a large number of contaminants at parts per trillion to parts per billion concentrations. The data can be used to study temporal and spatial distribution of contaminants in the Snake River Plain aquifer. Representative compressed chromatograms for all ground waters sampled in this study are available on two 3.5 -inch high density computer disks. The data and the program required to decompress the data can be obtained from the U.S. Geological Survey office at Idaho Falls, Idaho. Sulfur hexafluoride $\left(\mathrm{SF}_{6}\right)$ concentrations were measured in selected wells to determine the feasibility of using this environmental tracer as an age dating tool of ground water. Concentrations of dissolved nitrogen, argon, carbon dioxide, oxygen, and methane were measured in 79 ground waters. Concentrations of dissolved permanent gases are tabulated and will be used to evaluate the temperature of recharge of ground water in and near the INEEL.
\end{abstract}

\section{INTRODUCTION}

The Idaho National Engineering and Environmental Laboratory (INEEL), encompassing about $2,300 \mathrm{~km}^{2}$ of the eastern Snake River Plain in southeastern Idaho (fig. 1), was established in 1949 and is operated by the U.S. Department of Energy (DOE). INEEL facilities are used for the development of peacetime atomic energy applications such as nuclear safety research, defense programs, advanced energy programs, and advanced energy concepts. In the past, liquid radiochemical and chemical wastes generated at these facilities have been discharged to on site infiltration ponds, and disposal wells (Orr and Cecil, 1991; Bartholomay and others, 1997). Liquid-waste disposal has resulted in detectable concentrations of several waste 


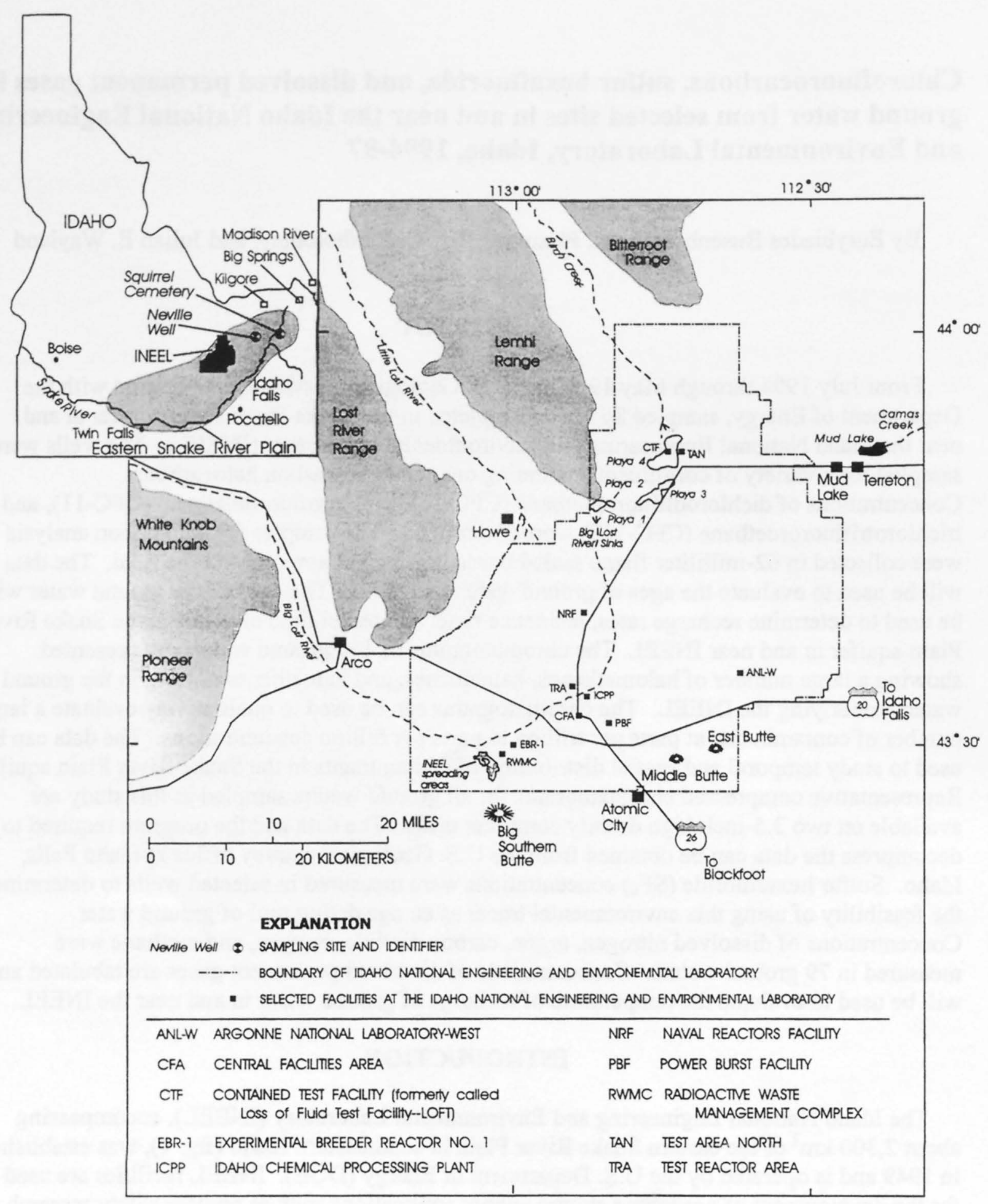

Figure 1. The Idaho National Engineering and Environmental Laboratory and selected facilities, southeastern Idaho. 
constituents in the Snake River Plain aquifer underlying the INEEL facility (Robertson and others, 1974; Orr and Cecil, 1991; Bartholomay and others, 1997).

The U.S. DOE requires information about the mobility of dilute radiochemical- and chemical-waste constituents in the Snake River Plain aquifer. Waste-constituents mobility is, in part, determined by (1) the rate and direction of ground-water flow; (2) the locations, qualities and methods of waste disposal; (3) waste-constituent chemistry, and (4) the geochemical processes in the aquifer (Robertson, 1974; Robertson and others, 1974). The data presented in this report will be used to study temporal and spatial distribution of contaminants in the Snake River Plane aquifer, and age date the ground water. The study was conducted by the U.S. Geological Survey in cooperation with the U.S. DOE's Idaho Operations Office.

\section{Purpose and Scope}

This report presents the concentrations of chlorofluorocarbons, sulfur hexafluoride and dissolved gases in and near the INEEL facility. The results of the analyses from 139 samples collected from 79 wells collected from 1994 through 1997 are presented along with a brief summary of field and laboratory procedures used for collection and analyses.

\section{Geohydrologic Setting}

The eastern Snake River Plain is a northeast-trending structural basin about $320 \mathrm{~km}$ long and 80 to $110 \mathrm{~km}$ wide. The plain is underlain by a layered sequence of basaltic lava flows and cinder beds interbedded with eolian, fluvial, and lacustrine sedimentary deposits. The thickness of specific flows generally ranges from 3 to $15 \mathrm{~m}$, and the average thickness may be from 6 to $7.5 \mathrm{~m}$ (Mundorff and others, 1964, p.143). The sedimentary deposits consist mainly of beds of sand, silt, clay, and lesser amounts of gravel. Locally, rhyolitic lava flows and tuffs are exposed at land surface or are present at depth. The basaltic lava flows and interbedded sedimentary deposits combine to form the Snake River Plain aquifer, which is the main source of water on the plain.

Ground-water movement in the Eastern Snake River Plain aquifer is from the northeast to the southwest. Recharge to the Snake River Plain aquifer is principally from ground-water inflow from the alluvium of adjoining mountain drainage basins, from infiltration of applied irrigation water, and infiltration of stream flow (Garabedian, 1992; Goodell, 1988; Lindholm, 1996). Some recharge may be from direct precipitation, although the small annual precipitation on the plain ( $20 \mathrm{~cm}$ at INEEL), evapotranspiration, and the great depth to water (in places, exceeding $275 \mathrm{~m}$ ) probably minimize this source of recharge (Rightmire and Lewis, 1987; Bartholomay and others, 1997, p.18).

The Big Lost River drains more than $3,600 \mathrm{~km}^{2}$ of mountainous area that includes parts of the Lost River Range and the Pioneer Range west of INEEL (fig. 1). Flow in the Big Lost River infiltrates to the Snake River Plain aquifer along its channel and at sinks and playas. Since 1958, excess runoff has been diverted to spreading areas in the southwestern part of the INEEL, where much of the water rapidly infiltrates to the aquifer. Other surface drainages that 
provide recharge to the Snake River Plain aquifer at INEEL includes Birch Creek, the Little Lost River, and Camas Creek (fig.1) (Brennan and others, 1996; Harenberg and others,1993).

Water in the Snake River Plain aquifer moves principally through fractures and interflow zones in the basalt. An appreciable proportion of the ground water moves through the upper 60 to $245 \mathrm{~m}$ of basaltic rocks (Mann, 1986, p. 21). Ackerman (1991, p. 30) reported a range of transmissivity of basalt in the upper part of aquifer from about 0.3 to $70,000 \mathrm{~m}^{2} / \mathrm{d}$. The hydraulic conductivity of underlying rocks is several orders of magnitude smaller (Mann, 1986, p. 21). The effective base of the Snake River Plain aquifer at INEEL probably ranges from about 250 to $535 \mathrm{~m}$ below land surface (Anderson and other, 1996, p. 23).

At INEEL, depth to water in wells completed in the Snake River Plain aquifer ranges from $60 \mathrm{~m}$ at the northern part near the boundary of the Snake River Plain aquifer to more than 275 $\mathrm{m}$ in the southern part. The direction of ground-water flow within the aquifer is mainly southward and southwestward at an average hydraulic gradient of about $0.7 \mathrm{~m} / \mathrm{km}$. Ground water moves southwestward from INEEL and eventually discharges to springs along the Snake River downstream from Twin Falls, about $160 \mathrm{~km}$ southwest of the INEEL (Robertson and others, 1974).

\section{Acknowledgments}

The authors are grateful to Daniel J. Phelan, Michael W. Doughten, and Brennon R. Orr of the U.S. Geological Survey for technical review of the manuscript.

\section{METHODS OF STUDY}

The procedures used to collect ground-water samples and the analytical methods for chlorofluorocarbons and other volatile halocarbons, sulfur hexafluoride, and dissolved permanent gases are complex and therefore each procedure will be discussed separately in this report.

Samples were collected from 95 locations (figs. 2-3); 75 ground-water monitoring wells; 7 domestic or stock wells; 6 production wells; 2 public supply wells; 2 irrigation wells; and 3 springs. The production wells, irrigation wells, and the Arco City Well \#2 were equipped with dedicated turbine pumps. The ground-water monitoring wells, domestic wells, stock wells, and the Atomic City well were equipped with dedicated submersible pumps. Data on the pumping rate, hole diameter, well depth, depth of intake, intake diameter, material of intake, perforation or open hole intervals, and the water level at the date of sampling are given in table 1 .

Samples were collected from a portable sampling apparatus from the monitoring wells and from sampling ports or spigots on other wells. All portable equipment was decontaminated after each sample. Samples were collected at each site after three well-bore volumes of water were purged and measurements of $\mathrm{pH}$, specific conductance, and water temperature were stable. Conditions at the sampling site during sample collection were recorded in a fieldbook. 


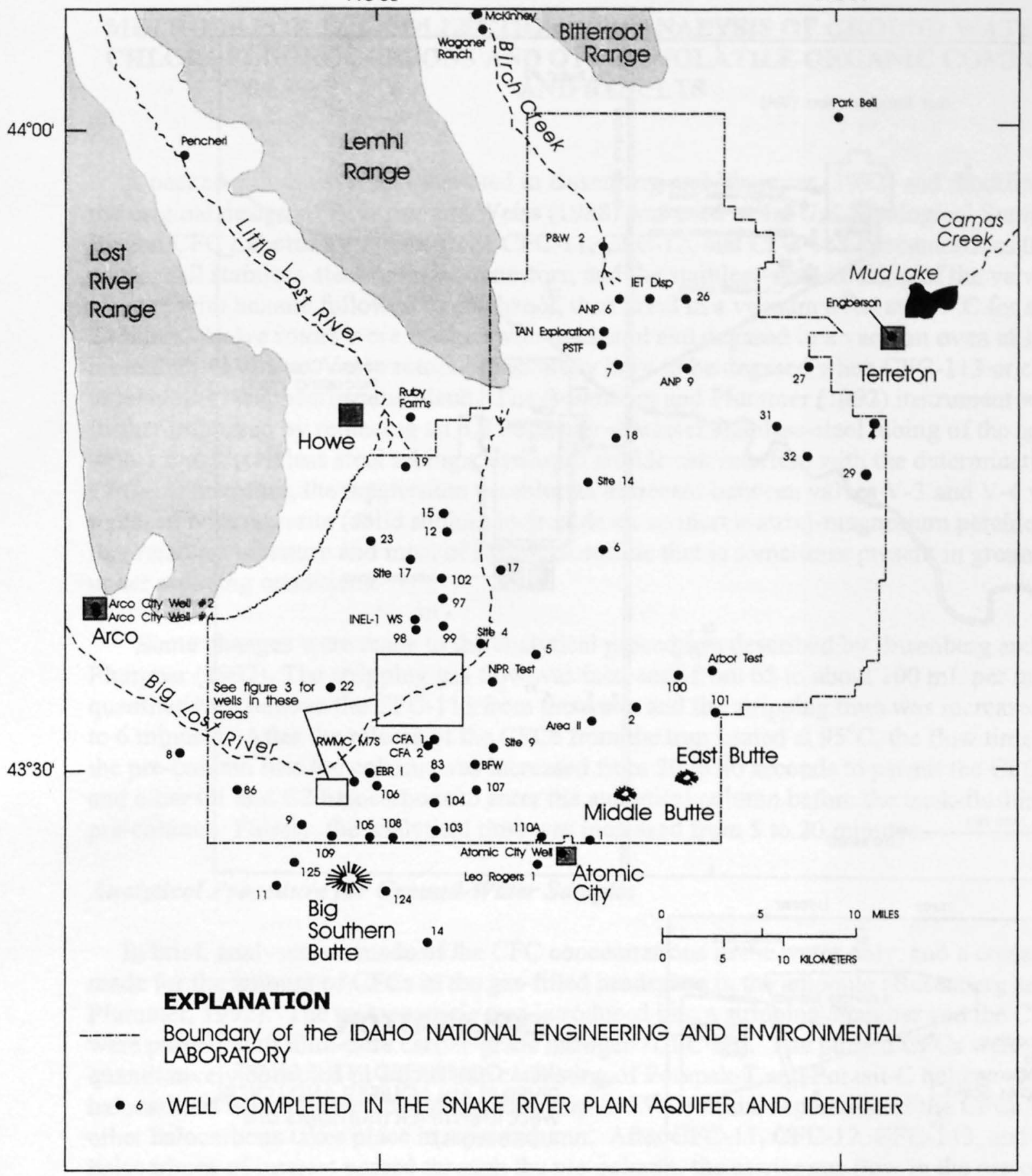

Figure 2. Location of wells sampled for chlorofluorocarbons and other constituents in and near the Idaho National Engineering and Environmental Laboratory. 

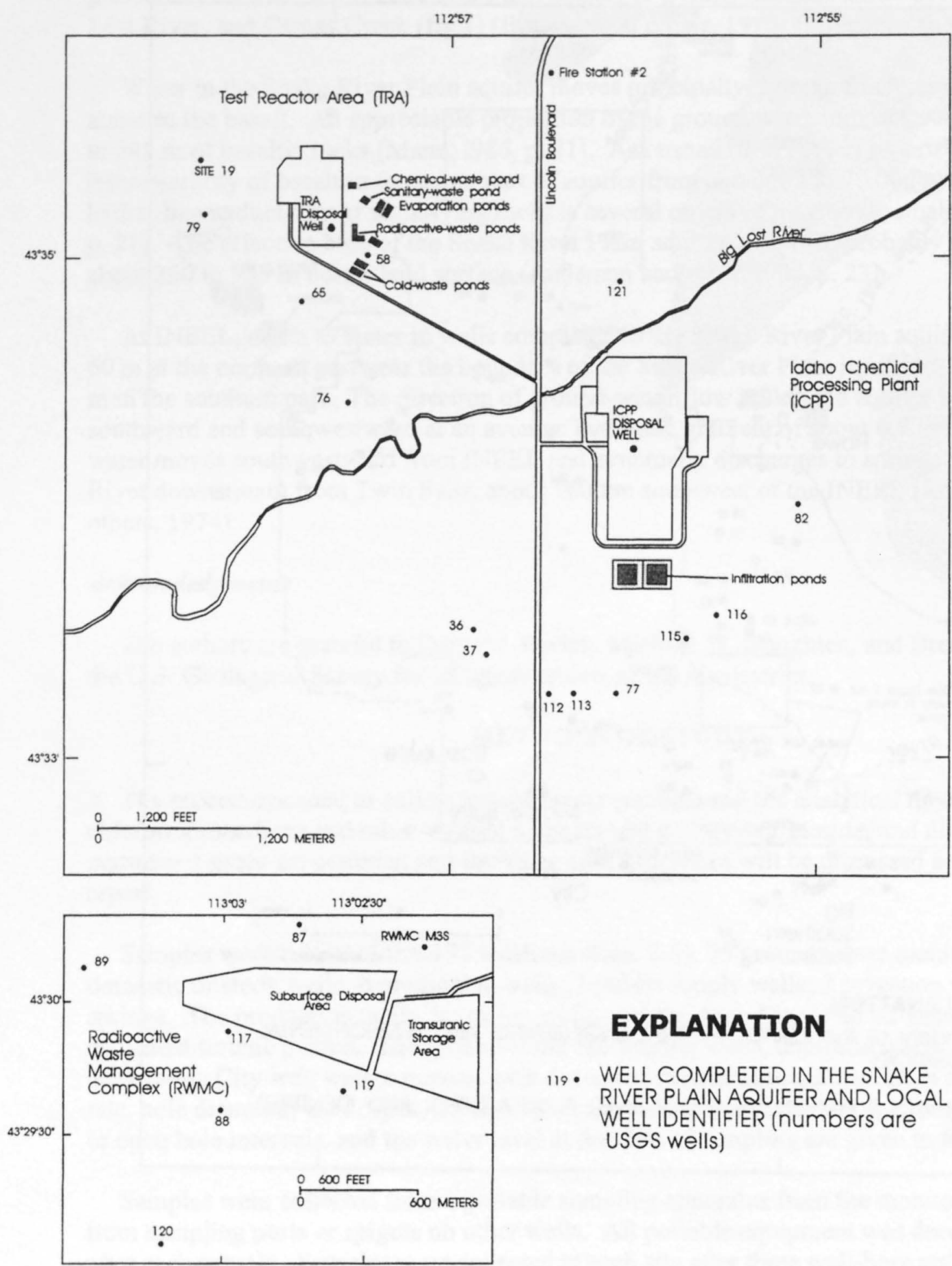

\section{EXPLANATION}

119. WELL COMPLETED IN THE SNAKE RIVER PLAIN AQUIFER AND LOCAL WELL IDENTIFIER (numbers are USGS Wells)

Figure 3. Location of wells sampled for chlorofluorocarbons and other constituents, Test Reactor Area, Idaho Chemical Processing Plant, and Radioactive Waste Management Complex in the Idaho National Engineering and Environmental Laboratory. 


\title{
METHODS FOR THE COLLECTION AND ANALYSIS OF GROUND WATER FOR CHLOROFLUOROCARBONS AND OTHER VOLATILE ORGANIC COMPOUNDS AND RESULTS
}

\begin{abstract}
A packed column system illustrated in Busenberg and Plummer (1992) and modified from the original design of Bullister and Weiss (1988) was used at the U.S. Geological Survey Reston CFC Laboratory to determine CFC-11, CFC-12, and CFC-113 concentrations in ground water. All stainless-steel tubing, connectors, and the stainless-steel housing of the valves were cleaned with hexane followed by methanol, then dried in a vacuum oven at $250^{\circ} \mathrm{C}$ for at least 24 hours. Valve rotors were washed with methanol and degased in a vacuum oven at $170^{\circ} \mathrm{C}$ for more than 48 hours. Valve rotors occasionally have to be degased when CFC-113 or carbon tetrachloride reappears in the blank. The Busenberg and Plummer (1992) instrument was further improved by replacing all $3.2 \mathrm{~mm}$ outer-diameter stainless-steel tubing of the apparatus with $1.6 \mathrm{~mm}$ stainless steel tubing. Hydrogen sulfide can interfere with the determination of CFC-11; therefore, the magnesium perchlorate desiccant between valves V-3 and V-4 was replaced with Ascarite (solid sodium hydroxide on an inert matrix)-magnesium perchlorate trap that removes moisture and most of hydrogen sulfide that is sometimes present in ground water under reducing conditions.
\end{abstract}

Some changes were made to the analytical procedures described by Busenberg and Plummer (1992). The stripping gas flow was increased from 65 to about $100 \mathrm{~mL}$ per minute to quantitatively remove the CFC-113 from the water and the stripping time was increased from 4 to 6 minutes. After the release of the $\mathrm{CFCs}$ from the trap heated at $95^{\circ} \mathrm{C}$, the flow time through the pre-column into the column was increased from 30 to 40 seconds to permit the CFC-113 and other $\mathrm{C} 1$ and $\mathrm{C} 2$ halocarbons to enter the analytical column before the back-flushing of the pre-column. Finally, the analytical time was increased from 5 to 20 minutes.

\section{Analytical Procedure for Ground-Water Samples}

In brief, analyses are made of the CFC concentrations in the water only, and a correction made for the amount of CFCs in the gas-filled headspace in the ampoule (Busenberg and Plummer, 1992). The water sample was introduced into a stripping chamber and the CFCs were purged with ultra-pure carrier-grade nitrogen ( $\mathrm{UPC} \mathrm{N}_{2}$ ). The purged CFCs were quantitatively collected in a cold trap consisting of Porapak-T and Porasil-C held at $-30^{\circ} \mathrm{C}$. The halocarbons were released by heating this trap to $95^{\circ} \mathrm{C}$. Initial separation of the $\mathrm{CFCs}$ from other halocarbons takes place in a pre-column. After CFC-11, CFC-12, CFC-113, and other halocarbons of interest passed through the pre-column, the carrier gas flow in the pre-column was reversed through valves V-6 and V-7. This procedure prevented other CFCs and halocarbons with higher retention times from entering the analytical column, back-flushed the pre-column and, thus, appreciably decreased the analysis time. The concentrations of the CFCs were measured with an electron capture detector (ECD). The concentrations of CFC-11, CFC12 , and CFC-1113 in the aquifer water were calculated from the concentrations in the water sample, the water-sample temperature, the volumes of water, and headspace in the ampoules (Busenberg and Plummer, 1992; Warner and Weiss, 1988; Bu and Warner, 1995). 


\section{Calibration of the Chlorofluorocarbon Analytical System}

Gas and water blanks were used extensively. The gas blanks of carrier or stripping gas were passed through the gas-sampling loops into the cold trap. The purpose of this procedure was to determine the CFC-11, CFC-12 and CFC-113 blanks of the instrument. Usually, no CFC signals were obtained from the gases. If a small concentration of CFC-12 in the blank was observed, it was an indication that the molecular-sieve traps (MS13X), through which the UPC gases were further purified, needed to be regenerated. The trap was re-generated by heating at 200 to $250^{\circ} \mathrm{C}$ for 6 hours as specified by Bullister and Weiss (1988). Water blanks were produced by stripping hot water in a glass flask for 2 hours with UPC $\mathrm{N}_{2}$. This nitrogen was purified by passing through an MS13X molecular-sieve trap. After the water was cooled, the water blank was introduced into the stripping cell of the analytical system and analyzed in the same manner as a regular sample. No CFC signals were normally observed from these water blanks.

The CFC-11, CFC-12 and CFC-113 primary standards are stainless-steel tanks that contain Oregon Standard Air with known concentrations of CFC-11, CFC-12 and CFC-113 (R. A. Rasmussen, Oregon Graduate Institute, written communication, 1988; 1991; 1993), and a tank purchased from National Oceanic and Atmospheric Administration (NOAA). The tanks were calibrated with primary gravimetric standards prepared by Ray Weiss at the Scripps Institute of Oceanography (Ray Weiss, Scripps Institute of Oceanography, written communication, 1995) and by NOAA. The concentrations of the CFCs are known to remain constant for many years in stainless-steel tanks that had their internal surfaces electropolished and passivated (Rasmussen and Khalil, 1983). Calibration curves for the CFCs were prepared by injecting six different volumes of the Oregon Standard Air through the gas-sampling loops into the instrument and then constructing calibration curves for CFC-11, CFC-12 and CFC-113 by the methods described by Bullister and Weiss (1988). Calibration of the gas-chromatograph system was done from standards run at the beginning and end of each day of analysis.

\section{Precision and Accuracy of Measurements}

Standard deviation of repeated measurements for this instrument are less than 2 percent for $\mathrm{CFC}-11, \mathrm{CFC}-12$, and about 3 percent for $\mathrm{CFC}-113$. The detection limits are $1 \mathrm{pg} / \mathrm{kg}$ for CFC113 and less than $1 \mathrm{pg} / \mathrm{kg}$ for CFC-11 and CFC-12. Precision was about 50 percent at the detection limit and about 3 percent above $25 \mathrm{pg} / \mathrm{kg}$. Eight standards and a blank were used for calibration because the ECD response does not vary linearly with concentration. The calibration ranges of the gas chromatograph was 0 to $1200 \mathrm{pg} / \mathrm{kg}$ for CFC-11, $0-2500 \mathrm{pg} / \mathrm{kg}$ for CFC-12, and $0-900 \mathrm{pg} / \mathrm{kg}$ for CFC-113. Reported concentrations beyond the above calibration limits should be considered as estimates of concentrations of the three CFCs.

\section{Results of Measurements}

CFCs were measured in at least three of the 5 to 6 ampoules collected during sampling. In a few cases, only two ampoules were analyzed because all other ampoules were broken during 
shipment. The results for the CFC-11 and CFC-12 concentrations for 1991 sampling at the INEEL are given in Busenberg and others (1993). Concentrations of CFC-11, CFC-12, and CFC-113, as well as the averages of all determinations and population standard deviations for the 1994 to 1996 sampling dates are given in table 2. Concentrations of all three halocarbons in the ground water ranged from $0 \mathrm{pg} / \mathrm{kg}$ to beyond the calibration range of the gas chromatograph ( 0 to $1,200,0$ to 2,500 , and $0-900 \mathrm{pg} / \mathrm{kg}$ for CFC-11, CFC-12 and CFC-113, respectively).

Representative chromatograms are presented in appendix A. Compressed digital chromatograms are available from samples analyzed since 1994. The chromatograms can be decompressed using the DOS program CONVERT that also is included in the package. Each chromatogram consists of approximately 20,000 points. The procedures of converting the compressed files to ASCII files that can be reprocessed or plotted are given in appendix B. The condensed files can be converted to files of more manageable length for plotting by this program.

A procedure is described in appendix $\mathrm{C}$ for normalizing the retention times of the various halocarbons detected by the ECD. Normalized times should be used to attempt to identify other peaks in the chromatograms. Normalized retention times for a number of halocarbons also are given in appendix C. Retention times alone are not sufficient to determine of the presence of a given halocarbon, nevertheless, the data can be used to study temporal and spatial distribution of contaminants in the Snake River Plain aquifer.

\section{METHODS FOR THE COLLECTION AND ANALYSIS OF GROUND WATER FOR SULFUR HEXAFLUORIDE AND RESULTS}

Concentration of sulfur hexafluoride $\left(\mathrm{SF}_{6}\right)$ in the 1998 troposphere is about four parts per trillion by volume or approximately 30 times less than the concentration of CFC-113 and almost 200 times less than the concentration of CFC-12 in the atmosphere. An additional complicating factor in the analysis of $\mathrm{SF}_{6}$ is its exceedingly low solubility in water. These two factors make it necessary to extract the tracer from a large volume of ground water prior to analysis. Three different extraction procedures for $\mathrm{SF}_{6}$ were tested in the laboratory and under field conditions, and are detailed below.

\section{Vacuum Extraction of Sulfur Hexafluoride from Ground Water}

The apparatus for the vacuum extraction of $\mathrm{SF}_{6}$ from ground water was similar to the system described by Law and others (1994) and Wanninkhof and Ledwell (1991). The apparatus consisted of a 1-liter glass vessel and various valves that controled the flow of gases, water, and the vacuum. First, a high vacuum was pulled in the 1-liter gas stripper. The vessel was isolated from the vacuum, then the water intake valve was opened. Water was sprayed through 6 nozzles into the stripping cell. After about $100 \mathrm{~mL}$ of water was added into the vessel, the valve was closed and the stripper was pressurized with $\mathrm{SF}_{6}$-free $\mathrm{N}_{2}$. The $\mathrm{N}_{2}$ pressure expelied the water to waste. The stripper then was re-evacuated. One liter of water was sprayed into the vacuum extracting about 90 percent of the $\mathrm{SF}_{6}$ from the water. $\mathrm{N}_{2}$ was introduced at the bottom of the one-liter stripping chamber through a frit and the $\mathrm{N}_{2}$ bubbled through the water removing the remaining 10 percent of the $\mathrm{SF}_{6}$. The stripping gas and $\mathrm{SF}_{6}$ 
were dried by passing through an Ascarite-magnesium perchlorate drier and the $\mathrm{SF}_{6}$ retained in a Porapak-Q trap, which had been pre-cooled to $-79^{\circ} \mathrm{C}$ with dry ice. After about 6 minute of stripping, the trap was sealed and removed. The SF 6 trap was replaced, the chamber emptied, and the apparatus was prepared for the next sample.

The vacuum stripping procedure was found to work very effectively in the laboratory. The necessary vacuum was produced in about 5 minutes in the laboratory; however, in the field at air temperatures of about $0^{\circ} \mathrm{C}, 30$ to 60 minutes were required to pull the necessary vacuum. This technique was used to collect 8 ground-water samples from INEEL in late October 1994.

\section{Headspace Gas Extraction of Sulfur Hexafluoride from Water}

In oceanography, high concentrations of $\mathrm{SF}_{6}$ are added to seawater and $\mathrm{SF}_{6}$ is used as a tracer of ocean currents. Seawater is sampled with a glass syringe and a nitrogen headspace is added. The syringe is shaken, then the headspace gas injected into a gas chromatograph. The procedure is discussed in detail by Law and others (1994), and Wanninkhof and Ledwell (1991). A variation of this procedure was used in this study.

The natural levels of $\mathrm{SF}_{6}$ are low and the tracer had to be extracted from 4 liters of water. The 4-liter bottle was filled with a tube inserted at the bottom of the container. After the bottle was filled, it was capped and connected up to a 3-way valve (Wanninkhof and Ledwell, 1991). A headspace of known volume was created by the addition of $\mathrm{SF}_{6}$-free nitrogen. The water was shaken and equilibrated with the ground water. The headspace gas then was removed from the bottle and was flame sealed into glass ampoules for $\mathrm{SF}_{6}$ analysis in the laboratory. The concentration of $\mathrm{SF}_{6}$ in the ground water was calculated from the volume of the headspace, the volume of the water, and the temperature of the water in the bottle.

\section{Direct Measurement of Ground Water}

Water samples were collected without headspace in 1-liter bottles and returned to the laboratory for $\mathrm{SF}_{6}$ analysis. The $\mathrm{SF}_{6}$ was vacuum extracted, collected on a trap and then injected into the analytical system.

\section{Analytical System for Sulfur Hexafluoride}

The analytical system initially built to measure $\mathrm{SF}_{6}$ was very similar to the instrument used by Law and others (1994), which is ideally suited for high concentration measurements onboard oceanographic vessels (Maiss and others, 1994; Wanninkhof and Ledwell, 1991). The analytical system consists of 1) a gas distribution system, 2) a sample introduction system, 3) gas loops and injection system, 4) a SF 6 trapping system, and 5) a chromatogaphic system. Each of these parts of the analytical system will be briefly discussed. It soon became obvious that the system was inadequate for the measurement of very low concentrations of $\mathrm{SF}_{6}$ normally found in ground waters. The instrument was modified to allow the stripping of much larger volumes of water. The design of the gas distribution system was critical for obtaining good chromatograms from very small signals that are obtained from natural levels of $\mathrm{SF}_{6}$. UPC $\mathrm{N}_{2}$ was used through out the system. The carrier gas was purified with a charcoal and an oxygen 
trap. The pressure of the gas was controlled with four ultra-clean pressure regulators and the flow adjusted by three needle valves. Additional pressure and flow regulation was provided by three dummy columns and a post-column. A flow controller was placed after the ECD to maintain constant carrier flow through the detector. All these measures prevented flow and pressure fluctuation during the switching of valves, which could have caused background drift and noise, a serious problem in other instruments (see fig. 4 in Watson and others, 1987). The sample introduction system consisted of a 4-position valve. This valve selected between two gas standards, air, and gas in glass ampoules for introduction into the sampling loops at ambient, sub-ambient, or greater than atmospheric pressures. All volumes in the gasintroduction system have been precisely measured and the pressures measured with a pressure transducer. The gas injection system consisted of three valves. The volumes of the loops ranged from 0.1 to $15 \mathrm{~mL}$. The loops could be directly injected into the analytical column or the $\mathrm{SF}_{6}$ could be trapped at $-75^{\circ} \mathrm{C}$ on the Porapak-Q trap. A valve was used to isolate the trap. After the $\mathrm{SF}_{6}$ was trapped, the trap was isolated and heated to $95^{\circ} \mathrm{C}$, the valve was switched from the back-flush position to the run position, and the trap was opened. The $\mathrm{SF}_{6}$ entered the analytical column and the chromatogaphy began. After the $\mathrm{SF}_{6}$ was determined, the valve was switched to the back-flush position preventing the $\mathrm{O}_{2}$ from entering the ECD.

\section{Calibration and Sulfur Hexafluoride Standards}

The instrument was calibrated using a blank, and $0.1,0.3,0.5,0.6 \mathrm{cc}$ of a $100 \mathrm{ppt}$ Scott gas standard. The gas was directly injected into the analytical columns or was trapped on the Porapak-Q trap and then injected onto the column. Both procedures yielded identical results indicating 100-percent efficiency in the trapping of $\mathrm{SF}_{6}$. The system also was calibrated by using a blank, and $5,10,15,30$, and $45 \mathrm{~mL}$ of a NOAA air standard. $\mathrm{SF}_{6}$ in air standards was trapped prior to injection into the analytical column.

\section{Precision and Accuracy of Measurements}

Standard deviations of about 3 percent were routinely obtained for repeated measurements of standards. The calibration was linear through the entire measuring range. Standards were prepared by gravimetric procedures, accuracy was better than 5 percent. For water samples, precision was about 50 percent at the detection limit of $0.02 \mathrm{fmol} / \mathrm{L}$ and about 5 percent for concentrations greater than $0.1 \mathrm{fmol} / \mathrm{L}$.

\section{Results of Measurements}

The concentration of $\mathrm{SF}_{6}$ in ground water from INEEL and vicinity are given in table 3 . The name of the wells, date of sampling, concentration of $\mathrm{SF}_{6}$ in $\mathrm{fmol} / \mathrm{L}$, population standard deviations, number of replicate samples, volume of water from which the $\mathrm{SF}_{6}$ was extracted, the extraction procedure used, and location where the extraction of $\mathrm{SF}_{6}$ was performed are presented in table 3. Concentrations of $\mathrm{SF}_{6}$ range from 0.00 to about $18 \mathrm{fmol} / \mathrm{L}$. Most groundwater sampled in and near the INEEL contained less than $1 \mathrm{fmol} / \mathrm{L}$. 
The sampling apparatus for dissolved gases was illustrated and described in detail elsewhere (Hobba and others, 1977; Pearson and others, 1978). Briefly, the apparatus consisted of a water chamber and a sidearm that was evacuated before sampling. The $500-\mathrm{mL}$ water chamber was connected to the well with flexible Tygon tubing. The upward flow of water from the well completely filled the water chamber and removed all the air. After the chamber was thoroughly flushed, it was sealed from the atmosphere. The water chamber was then opened to the evacuated $50-\mathrm{mL}$ sidearm. The sampling apparatus was allowed to equilibrate for about 3 days at room temperature. The post-1995 samples for dissolved gases were collected in 150-mL bottles that were filled without headspace in the field. A $10-\mathrm{mL}$ headspace was created in the laboratory by removing some of the water using a syringe-needle and a vacuum pump. The water was allowed to equilibrate with this headspace for about 3 days at room temperature before analysis.

The sampler then was connected to a gas-chromatographic system. The pressure within the headspace was measured with a pressure transducer. Some headspace gas then was injected into two different columns in the gas chromatograph. The CTR-III column (Altech) was used to separate the $\mathrm{Ar}, \mathrm{N}_{2}$, and $\mathrm{O}_{2}$, and the CTR-I column to separate the $\mathrm{CH}_{4}$ from the $\mathrm{CO}_{2}$. The concentrations $\mathrm{Ar}, \mathrm{N}_{2}$, and $\mathrm{O}_{2}$ were measured with a thermal conductivity detector (TCD). After the separation of $\mathrm{CH}_{4}$, and $\mathrm{CO}_{2}$ by the second column, the gas was passed through a methanizer to convert the $\mathrm{CO}_{2}$ to $\mathrm{CH}_{4}$, then the gas was passed through a flame ionization detector (FID). Concentrations of $\mathrm{Ar}, \mathrm{N}_{2}, \mathrm{O}_{2}, \mathrm{CO}_{2}$, and $\mathrm{CH}_{4}$ in the ground water were calculated from the temperature, the headspace pressure, the volumes of water and headspace, and the gas law. The partial pressures of the gases in the ground water were calculated from the temperature using Henry's law (Wilhem and others, 1977; Weiss, 1970).

A blank, a NOAA air standard, and 4 certified gas mixtures obtained from Air Products were used to calibrate the dissolved-gas system. These gravimetric gas mixtures were standardized by gas chromatography and mass spectroscopy.

\section{Precision and Accuracy of Measurements}

Standard deviations of better than 3 percent were routinely obtained for repeated measurements of standards. The calibration was linear through the entire measuring range. Precision of about 3 percent can be obtained for the five gases if the samples are sterilized by the addition of mercuric chloride. Because the addition of mercuric chloride creates a disposal problem, mercury was not added to the INEEL samples and, thus, the concentrations of $\mathrm{O}_{2}$ and $\mathrm{CO}_{2}$ were not stabilized. Bacterial activity in the samples was reduced by placing the samples on ice in a cooler in the field. The samples were stored at $4^{\circ} \mathrm{C}$ prior to analysis. In spite of these measures, results indicate that $\mathrm{O}_{2}$ concentrations decreased and $\mathrm{CO}_{2}$ concentrations increased during storage at $4^{\circ} \mathrm{C} . \mathrm{CO}_{2}$ concentrations can easily and accurately be calculated from $\mathrm{pH}$ and alkalinity. Dissolved $\mathrm{O}_{2}$ concentrations can be measured in the field with a 
dissolved $\mathrm{O}_{2}$ meter. The main reason for collecting the samples was to determine the concentrations of $\mathrm{N}_{2}$ and $\mathrm{Ar}$ that can be used to calculate recharge temperature of the ground water (Busenberg and others, 1993). The concentration of $\mathrm{Ar}$ and $\mathrm{N}_{2}$ gases remained unchanged during storage at $4^{\circ} \mathrm{C}$.

In addition to the gas standards used to calibrate the dissolved gas system, three water standards equilibrated with air at temperatures of $8.9,16.0$ and $24.3^{\circ} \mathrm{C}$ were run daily. The concentrations of all gases were calculated using Henry's law (Wilhem and others, 1977; Weiss, 1970), the measured temperature, the measured barometric pressure, and the known composition of air. The average of the absolute difference between the observed and the calculated temperatures was $0.33^{\circ} \mathrm{C}$. The standard deviation of the absolute difference was $0.27^{\circ} \mathrm{C}$. Only 1.9 percent of the samples had temperature differences more than $1^{\circ} \mathrm{C}$. The temperature difference never exceeded $2^{\circ} \mathrm{C}$ in the water standards.

\section{Results of Measurements}

The dissolved gas results for the 1991 samples are given in Busenberg and others (1993). The results of the more recent sampling are given in table 4. Included in the table are the well names, date of sampling, concentrations of $\mathrm{CH}_{4}, \mathrm{CO}_{2}, \mathrm{~N}_{2}, \mathrm{O}_{2}$ and $\mathrm{Ar}$, as well as the number of replicates analyzed. The $\mathrm{O}_{2}$ and $\mathrm{CO}_{2}$ concentrations in the ground water (in parenthesis to the nearest $0.5 \mathrm{mg} / \mathrm{L}$ ) were estimated from the number of days of storage and the rates of change as a function of time. Rates of $\mathrm{O}_{2}$ consumption and $\mathrm{CO}_{2}$ production were calculated from changes in concentration of replicate ground water from INEEL stored for different periods of time. The rates obtained were applied to all ground water from INEEL. Because concentrations of $\mathrm{O}_{2}$ decreased and $\mathrm{CO}_{2}$ increased with storage time, the measured concentrations reported in table 4 are for the sample with the shortest storage time rather than the average concentration of replicates. Concentrations of $\mathrm{CH}_{4}, \mathrm{~N}_{2}$, and $\mathrm{Ar}$ do not change with storage time; thus, averages of replicates are reported in table 4.

The concentrations ranged from 3.1 to 17 , from 13.74 to more than 49 , from 0 to 10 , and from 0.526 to $1.17 \mathrm{mg} / \mathrm{L}$ for $\mathrm{CO}_{2}, \mathrm{~N}_{2}, \mathrm{O}_{2}$, and $\mathrm{Ar}$, respectively. The highest concentrations of $\mathrm{N}_{2}$ and Ar were observed in USGS 104 (table 4), a well with a hole in the intake tube. This hole allows some air to mix with the ground water. Concentrations of methane were below the detection limit of $0.0002 \mathrm{mg} / \mathrm{L}$ for most samples.

\section{SUMMARY}

This report presents concentrations of three chlorofluorocarbons, (CFC-11, CFC-12, and CFC-113), sulfur hexafluoride, and dissolved permanent gases in ground water at INEEL and vicinity. A total of 139 ground waters from 79 wells were sampled for CFCs. Concentrations for CFC-11, CFC-12 and CFC-113 are presented in table 2. Concentrations of all three halocarbons in the ground water ranged from $0 \mathrm{pg} / \mathrm{kg}$ to beyond the calibration range of the gas chromatograph (0 to $1,200,0$ to 2,500 , and $0-900 \mathrm{pg} / \mathrm{kg}$ for CFC-11, CFC-12 and CFC-113, respectively). Chromatograms from 139 ground water samples are given in an appendix. 
Sulfur hexafluoride concentrations were measured in 72 samples representing 51 wells completed in the Snake River Plain aquifer. Concentrations of $\mathrm{SF}_{6}$ range from 0.00 to about 18 $\mathrm{fmol} / \mathrm{L}$, but most of the ground waters in and near the INEEL contained less than $1 \mathrm{fmol} / \mathrm{L}$.

Dissolved permanent gases were measured in 89 ground waters from 75 wells in and near the INEEL, and 3 springs. The concentrations ranged from 3.1 to 17 , from 13.7 to more than 49 , from 0 to 10 , and from 0.526 to $1.17 \mathrm{mg} / \mathrm{L}$ for $\mathrm{CO}_{2}, \mathrm{~N}_{2}, \mathrm{O}_{2}$, and $\mathrm{Ar}$, respectively.

Compressed digital chromatograms are available for all samples analyzed since 1994. Representative compressed chromatograms for all 139 ground waters sampled in this study are available on two 3.5 -inch high density computer disks. The data and the program required to decompress the data can be obtained from the U.S. Geological Survey office at Idaho Falls, Idaho.

\section{REFERENCES CITED}

Ackerman, D.J., 1991, Transmissivity of the Snake River Plain aquifer at the Idaho Nation Engineering Laboratory, Idaho: U.S. Geological Survey Water-Resources Investigations Report 91-4058 (DOE/ID-22097), 35 p.

Anderson, S.R., Ackerman, D.J., Liszewski, M.J., and Freiburger, R.M., 1996, Statigraphic data for wells at and near the Idaho National Engineering Laboratory, Idaho: U.S. Geological Survey Open-Rile Report 96- 248 (DOE/ID-22127), 27 p.

Bartholomay, R.C., Tucker, B.J., Ackerman, D.J., and Liszewski, M.J., 1997, Hydrologic conditions and distribution of selected radiochemical and chemical constituents in water, Snake River Plain aquifer, Idaho National Engineering Laboratory, Idaho 1992 through 1995: U.S. Geological Survey Water-Resources Investigations Report 97-4086 (DOE/ID-22137), 57 p.

Brennan, T. S., O'Dell, I., and Tungate, A. M., 1996, Water resources data, Idaho water year 1995-volume 1. Great Basin and Snake River Basin above King Hill: U.S. Geological Survey Water-Data Report ID 95-1, 452 p.

Bu, X., and Warner, M. J., 1995, Solubility of chlorofluorocarbon 113 in water and seawater: Deep-Sea Research, v. 42, p. 1151-1161.

Bullister, J. L., and Weiss, R. F., 1988, Determination of $\mathrm{CCl}_{3} \mathrm{~F}$ and $\mathrm{CCl}_{2} \mathrm{~F}_{2}$ in seawater and air: Deep-Sea Research, v. 35, p. 839-854.

Busenberg, E., and L.N. Plummer, 1992, Use of chlorofluoromethanes $\left(\mathrm{CCl}_{3} \mathrm{~F}\right.$ and $\left.\mathrm{CCl}_{2} \mathrm{~F}_{2}\right)$ as hydrologic tracers and age-dating tools: Example-the alluvium and terrace system of Central Oklahoma, Water Resources Research: v. 28, p. 2257-2283. 
Busenberg, E., Weeks, E. P., Plummer, L. N., and Bartholomay, R. C., 1993, Age dating ground water by use of chlorofluorocarbons $\left(\mathrm{CCl}_{3} \mathrm{~F}\right.$ and $\left.\mathrm{CCl}_{2} \mathrm{~F}_{2}\right)$, and distribution of chlorofluorocarbons in the unsaturated zone, Snake River Plain aquifer, Idaho National Engineering Laboratory, Idaho: U.S. Geological Survey Water-Resources Investigations Report 93-4054, (DOE/ID-22107), 47 p.

Garabedian, S. P., 1992, Hydrology and digital simulation of the regional aquifer system, Eastern Snake River Plain, Idaho: U.S. Geological Survey Professional Paper 1408-F, 101 p.

Goodell, S. A., 1988, Water use on the Snake River Plain, Idaho and Eastern Oregon: U.S. Geological Survey Professional Paper 1408-E, 51 p.

Harrenberg, W. A., Jones, M. L., O’Dell, I., Brennan, T. S., Lehmann, A. K., and Tungate, A. M., 1993, Water resources data, Idaho, water year 1992 - volume 1. Great Basin and Snake River Basin above King Hill: U.S. Geological Survey Water-Data Report ID-92-1, 377 p.

Hobba, W. A., Chemreys, J. C., Fisher, D. W., and Pearson, F. J., 1977, Geochemical and hydrologic data for wells and springs in thermal-spring areas of the Appalachians: U.S. Geological Survey Water-Resources Investigations Report 77-25, 36 p.

Law, C. S., Watson, A. J., and Liddicoat, M. I., 1994, Automated vacuum analysis of sulfur hexafluoride in seawater: Derivation of the atmospheric trend (1979-1993) and potential as a transient tracer: Marine Chemistry, v. 48, p. 57-69.

Lindholm, G. F., 1996, Summary of the Snake River Plain regional aquifer-system analysis in Idaho and Eastern Oregon: U.S. Geological Survey Professional Paper 1408-A, 59 p.

Maiss, M., Ilmberger, J., Zenger, A., and Munich, K. O., 1994, A SF 6 tracer study of horizontal mixing in Lake Constance: Aquatic Science, v. 56, p. 307-328.

Mann, L.J., 1986, Hydraulic properties of rock units and chemical quality of water at INEL-1 A 10,365-foot deep test hole drilled at the Idaho National Engineering Laboratory, Idaho: U.S. Geological Survey Water-Resources Investigations Report 86-4020 (DOE/ID-22070), 23 p.

Mundorff, M.J., Crosthwaite, E.G., and Kilburn, C., 1964, Ground water for irrigation in the Snake River Basin in Idaho: U.S. Geological Survey Water-Supply Paper 1654, 224 p.

Orr, B. R., Cecil, L. D., 1991, Hydrologic conditions and distribution of selected chemical constituents in water, Snake River Plain aquifer, Idaho National Engineering Laboratory, Idaho, 1986 to 1988: U.S. Geological Survey Water-Resources Investigations Report 91-4047, 56 p.

Pearson, F. J., Jr., Fisher, D. W., and Plummer, L. N., 1978, Correction of ground-water chemistry and carbon isotopic composition for effects of $\mathrm{CO}_{2}$ degasing: Geochimica et Cosmochimica Acta, v. 42, p. 1799-1807. 
Rasmussen, R. A. and M. A. K. Khalil, 1983, Interlaboratory comparison, preparation, and stability of dichlorofluoromethane samples and standards: Analytical Chemistry, v.55, p. 18341836.

Robertson, J. B., 1974, Digital modeling of radioactive and chemical waste transport in the Snake River Plain aquifer at the National Reactor Testing Station, Idaho: U.S. Geological Survey Open-File Report IDO-22054, 41 p

Robertson, J. B., Schoen, R., and Barraclough, J. T., 1974, The influence of liquid waste disposal on the geochemistry of water at the National Reactor Testing Station, Idaho: 19521970: U.S. Open-File Report IDO-22053, 231 p.

Rightmire C. T., and Lewis, B. D., 1987, Hydrology and geochemistry of the unsaturated zone, Radioactive Waste Management Complex, Idaho National Engineering Laboratory, Idaho: U.S. Geological Survey Water-Resources Investigations Reort 87-4198.

Wannninkhof, R., and Ledwell, T. R., 1991, Analysis of sulfur hexafluoride in seawater: Journal of Geophysical Research, v. 98C, p. 8733-8740.

Warner and Weiss, R. F., 1988, Solubilities of chlorofluocarbon-11 and chloroflurocarbon-12 in water and seawater: Deep-Sea Research, v. 32, p. 1485-1495.

Watson, A. J., Ledwell, J. R., and Southerland, S. C., 1987, The Santa Monica Basin tracer experiment-Comparison of release methods and performance of perfluorodecalin and sulfur hexafluoride: Journal of Geophysical Reseach, v. 96C, p. 8719-8725.

Weiss, R. F., 1970, The solubility of nitrogen, oxygen, and argon in water and seawater: DeepSea Reasearch, v. 17, p. 721-735.

Wilhelm, E., Battino, R., and Wilcox, R. J., 1977, Low-pressure solubility of gases in liquid water: Chemical Reviews, v. 77, p. 219-262. 


\begin{abstract}
APPENDIX A
Chromatograms of 139 ground waters collected in or near the Idaho National Engineering and Environmental Laboratory, and the instrument blank. The name of the well, date of sampling, the name of the digital file of the chromatogram, and the chromatogram number for each ground water is given below the integrator output. The chromatograms show relative concentrations of halomethanes, haloethanes, and haloethenes. The detection limits are at parts per trillion to low parts per billion for the various compounds. Numbers next to the peaks represent retention times in minutes for the various compounds present. Retention times should be normalized by the procedure described in appendix $\mathrm{C}$. The integrator was started at time 0.0 , however the sample was injected from the trap through the pre-column into the analytical column at 0.50 minutes. At 1.30 minutes the trap and pre-column were removed from the carrier flow path. The broad peak between 0.5 and 1.3 minutes is the response of the electron capture detector to a small change in the carrier-gas flow. Note the scale changes at 5.00 minutes on the chromatograms. The integrator attenuation was set at 64 between 0 and 5.0 minutes and at 16 between 5.0 and 19.0 minutes. In this appendix, the vertical scale from 0 to 5.00 minutes is 1 centimeter equals 7 millivolts and the vertical scale from 5.00 to 19.00 minutes is 1 centimeter equals 1.66 millivolts. Exact peak hights can be obtained from the digitally reprocessed chromatograms as described in appendix B.
\end{abstract}




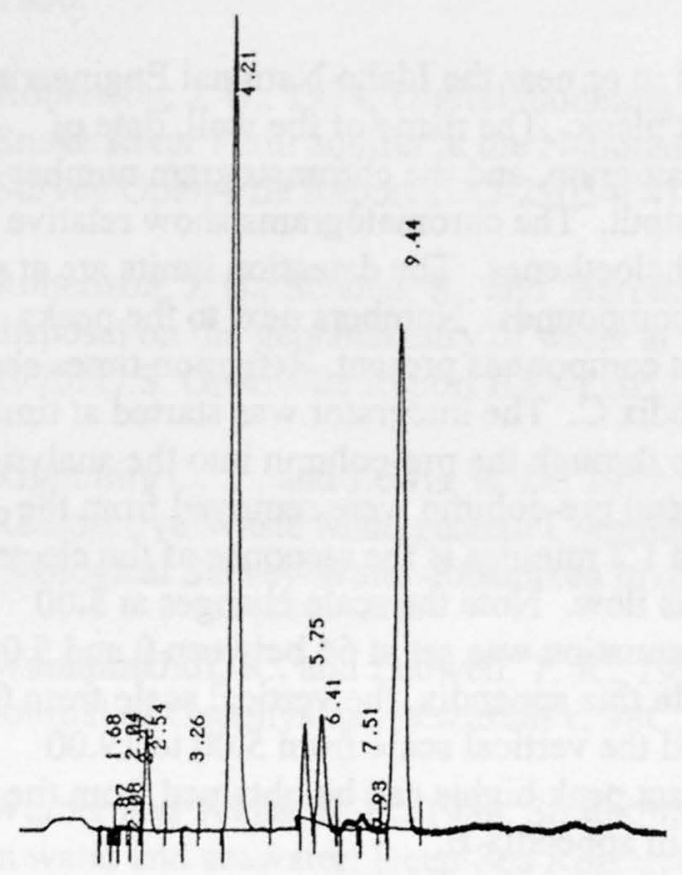

ANP 6, 10/14/94, ID50015.RAW, No. 1

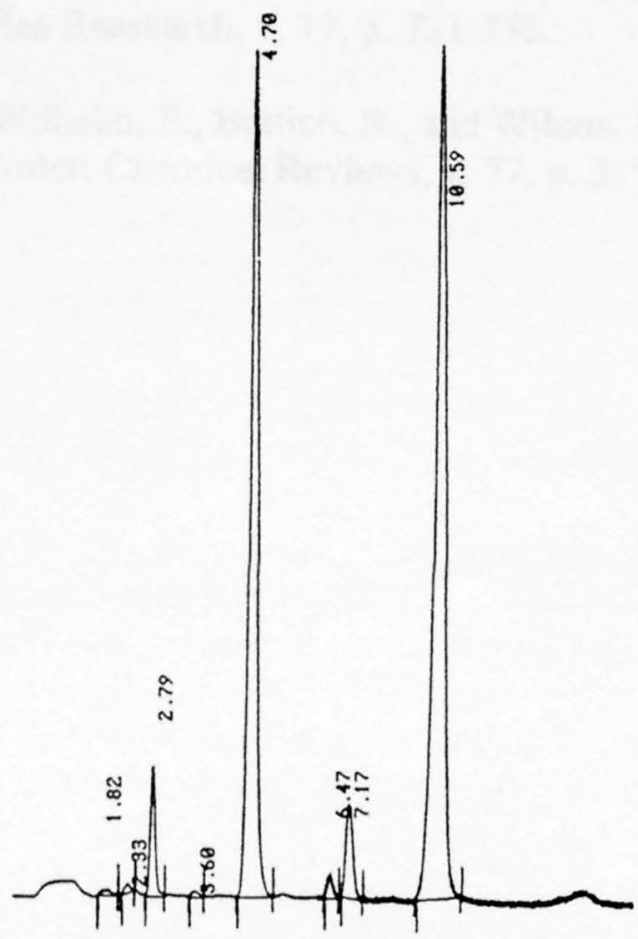

ANP 6, 7/19/96, ID41019.RAW, No. 3

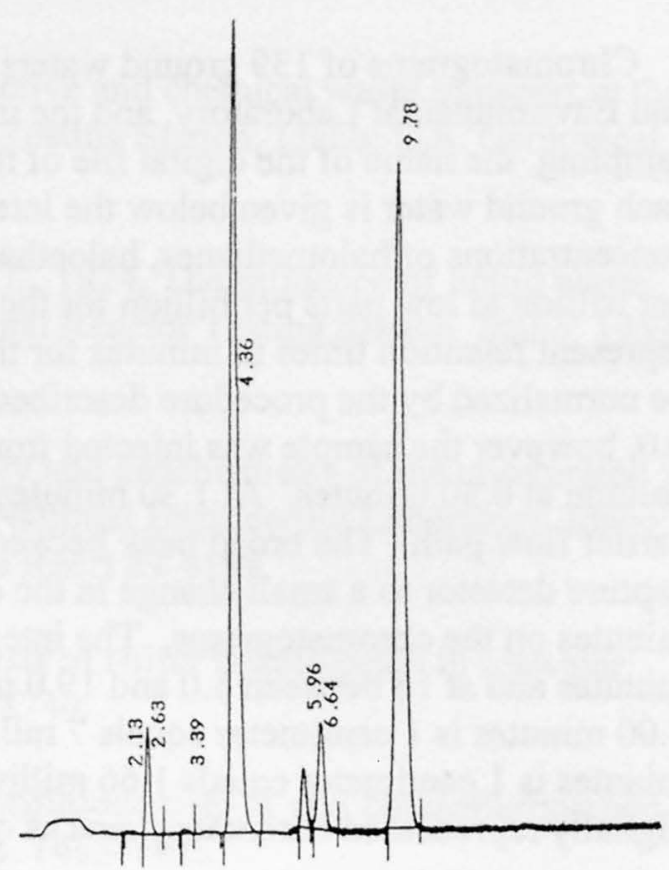

ANP 6, 6/15/95, ID46017.RAW, No. 2

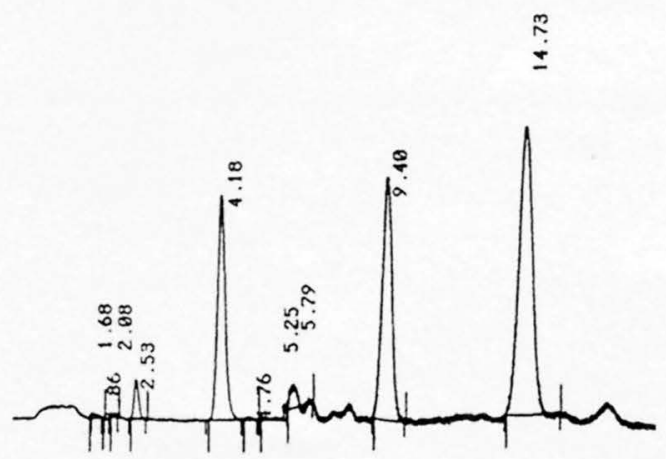

ANP 9, 10/14/94, ID50016.RAW, No. 4 


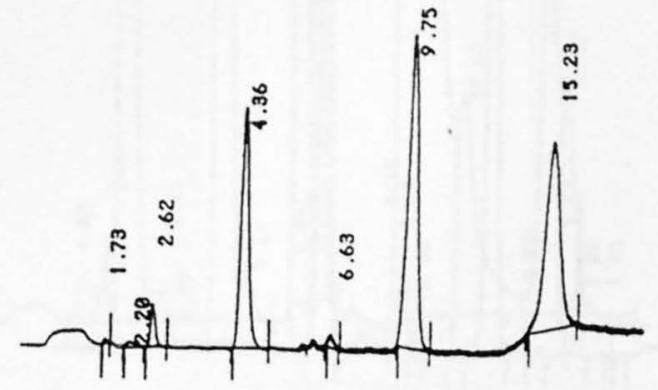

ANP 9, 10/14/96, ID48020.RAW, No. 5

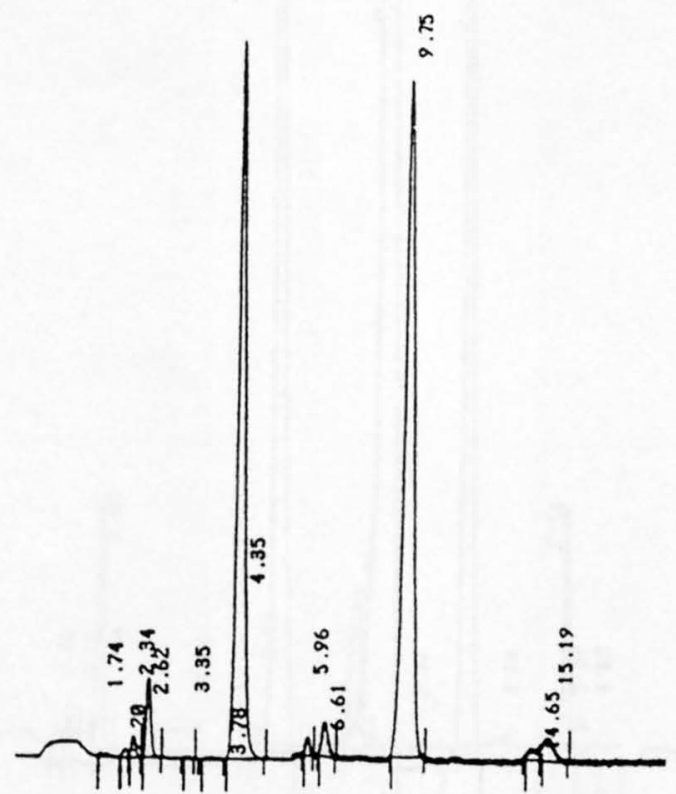

Arbor Test, 10/10/96, ID47019.RAW, No. 7

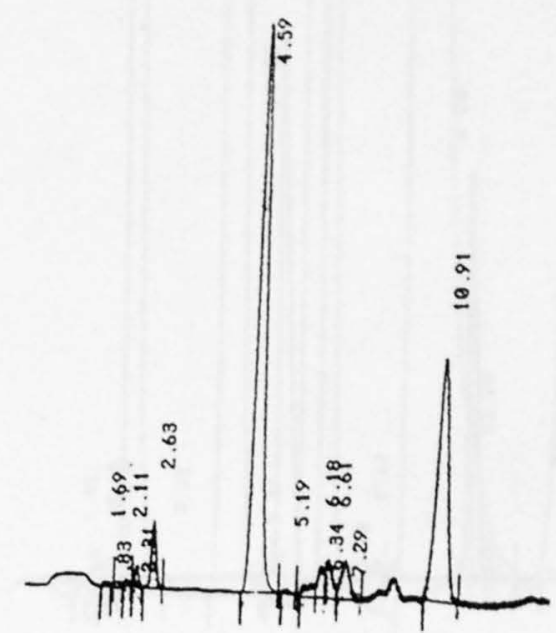

Arbor Test, 4/21/95, SC03018.RAW, No. 6

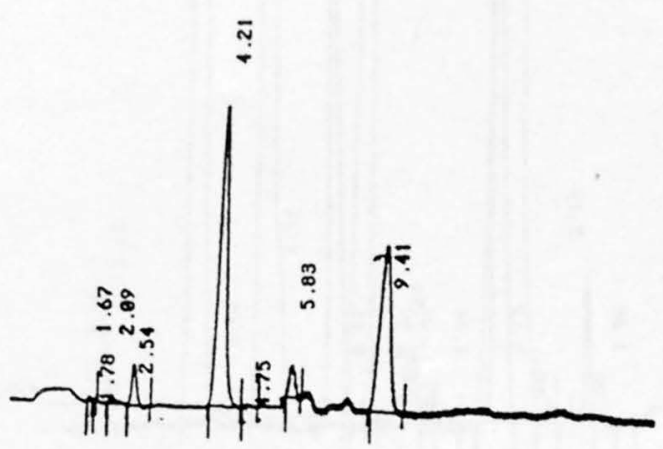

Area II, 7/19/94, ID49012.RAW, No. 8 


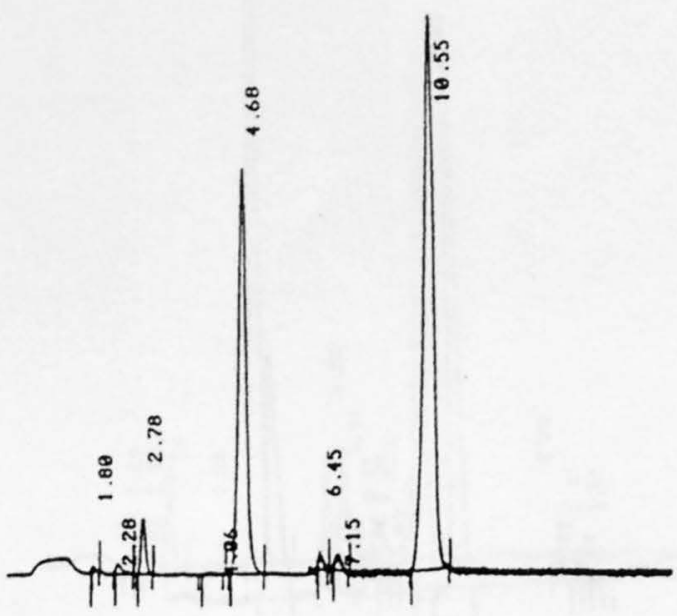

Area II, 7/18/96, ID37019.RAW, No. 9

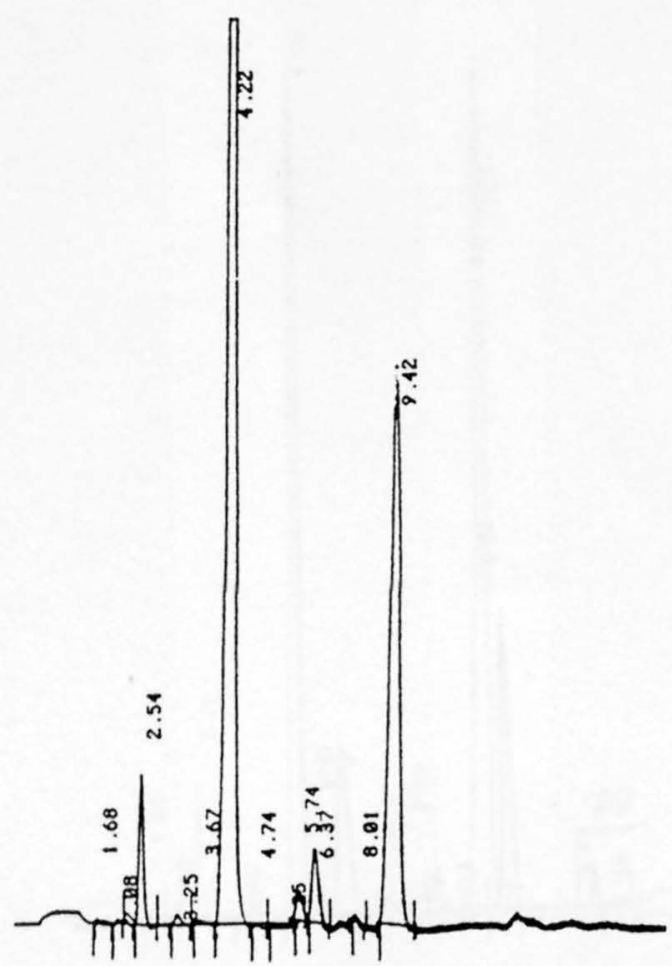

Atomic City, 10/9/96, ID50009.RAW, No. 11

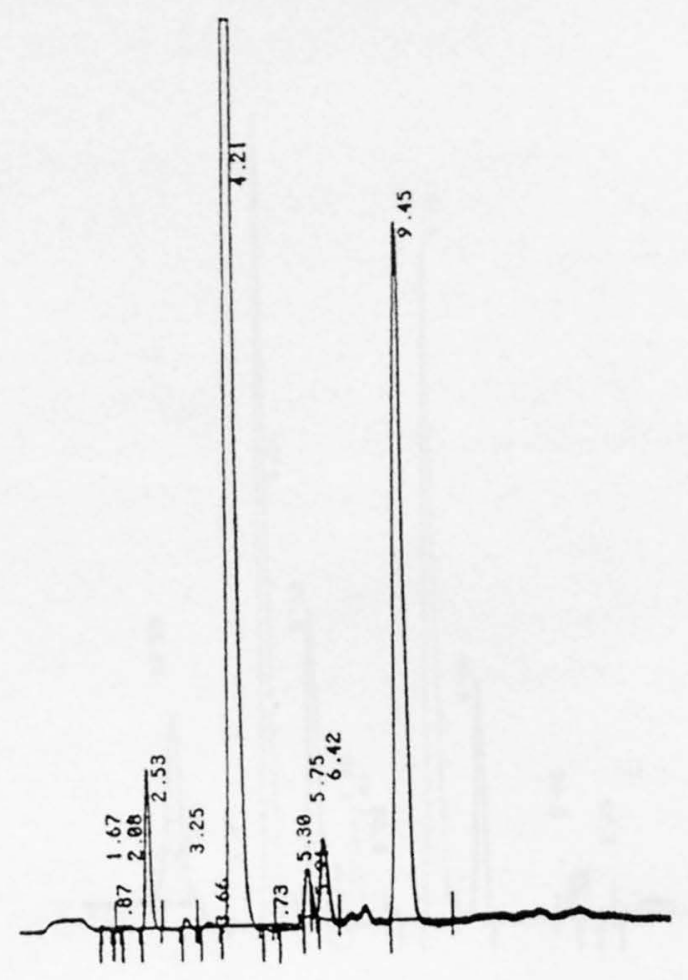

Atomic City, 10/3/94, ID50017.RAW, No. 10

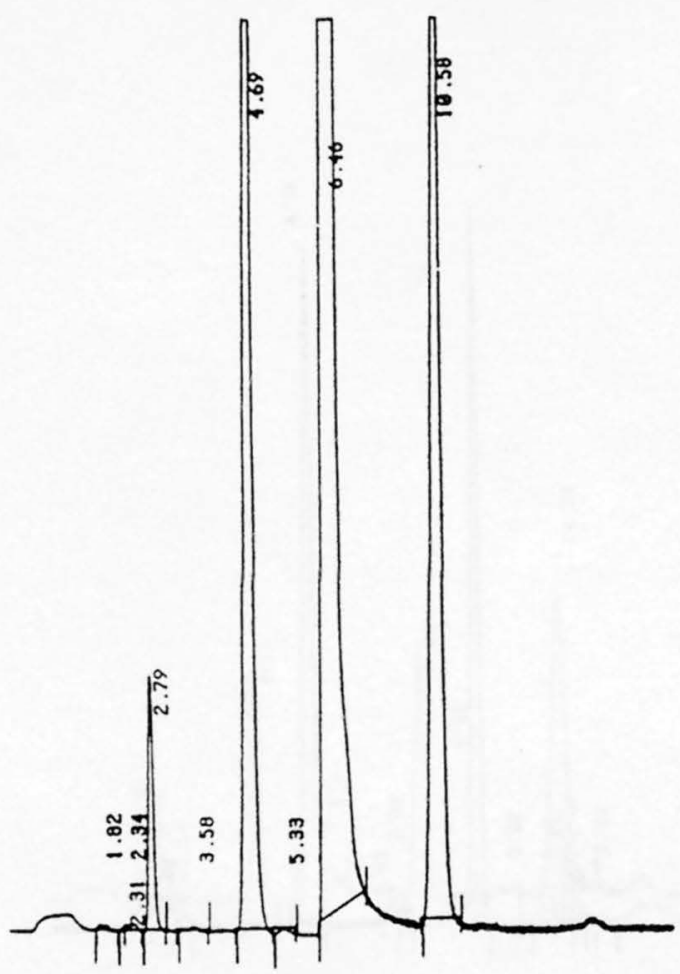

BFW, 7/16/96, ID40016.RAW, No. 12

20 


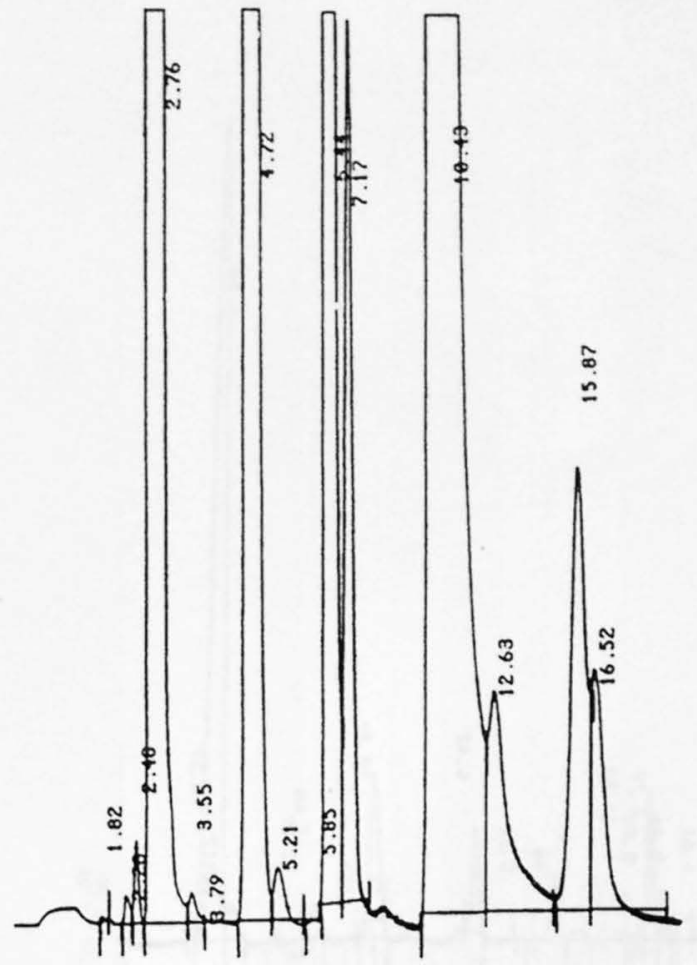

CFA 1, 7/16/96, ID40018.RAW, No. 13

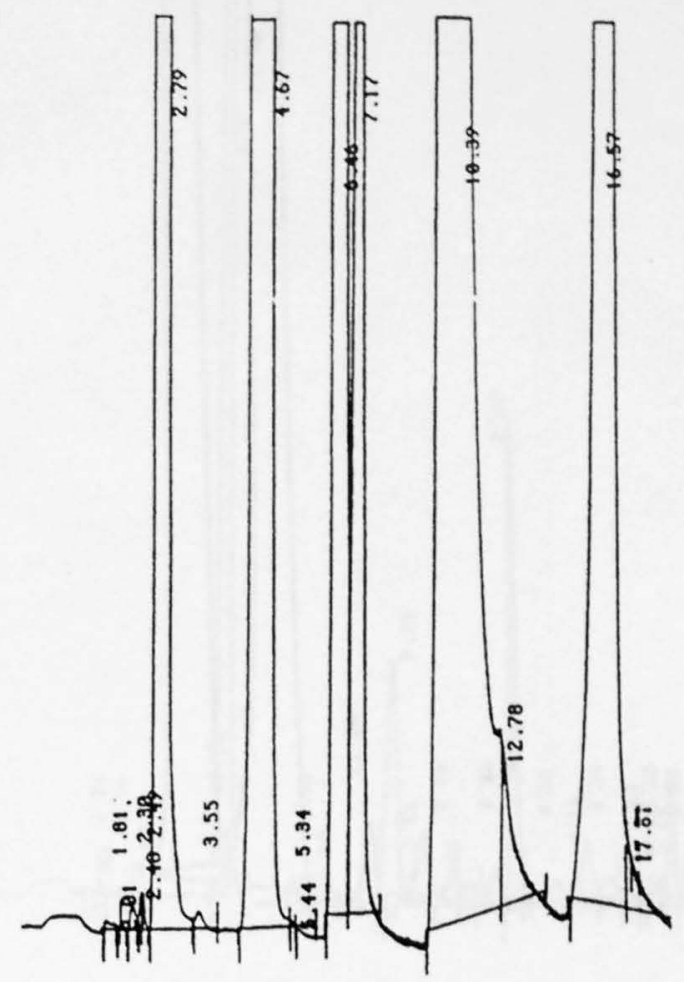

CFA 2, 7/16/96, ID40020.RAW, No. 14

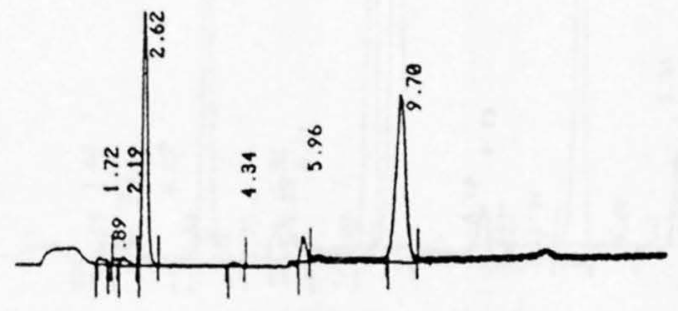

EBR 1, 10/16/96, ID43019.RAW, No. 15

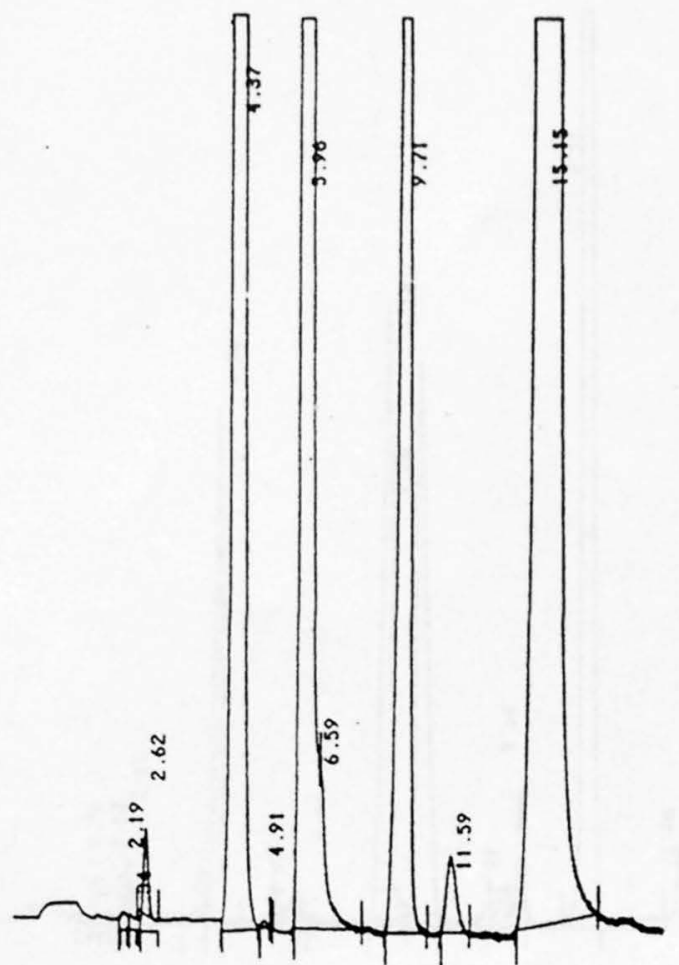

Fire Station 2, 10/16/96, ID43018.RAW, No. 16 


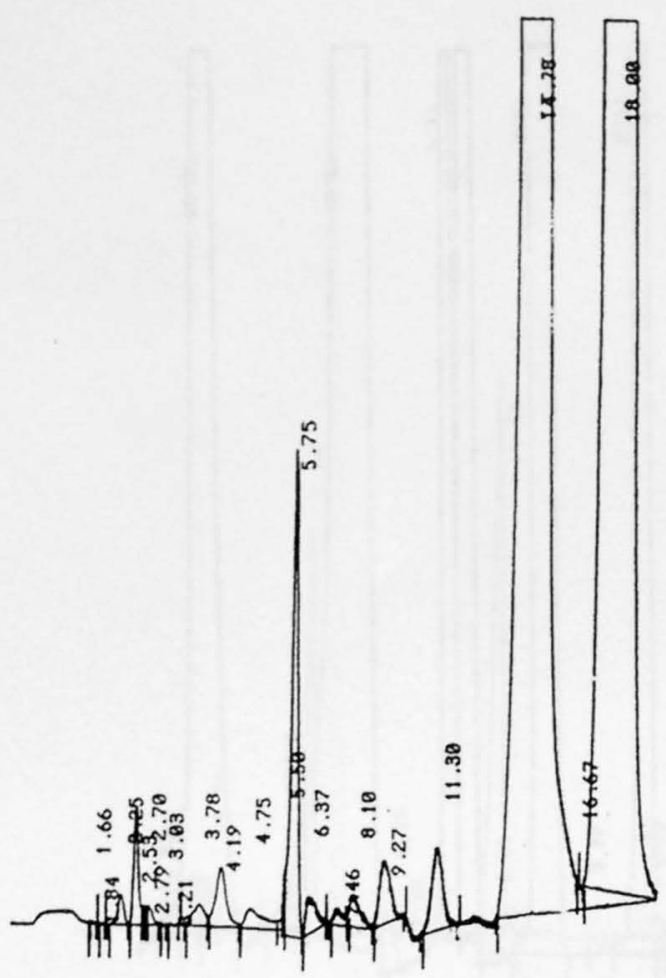

IET Disposal, 7/18/94, ID49021.RAW, No. 17

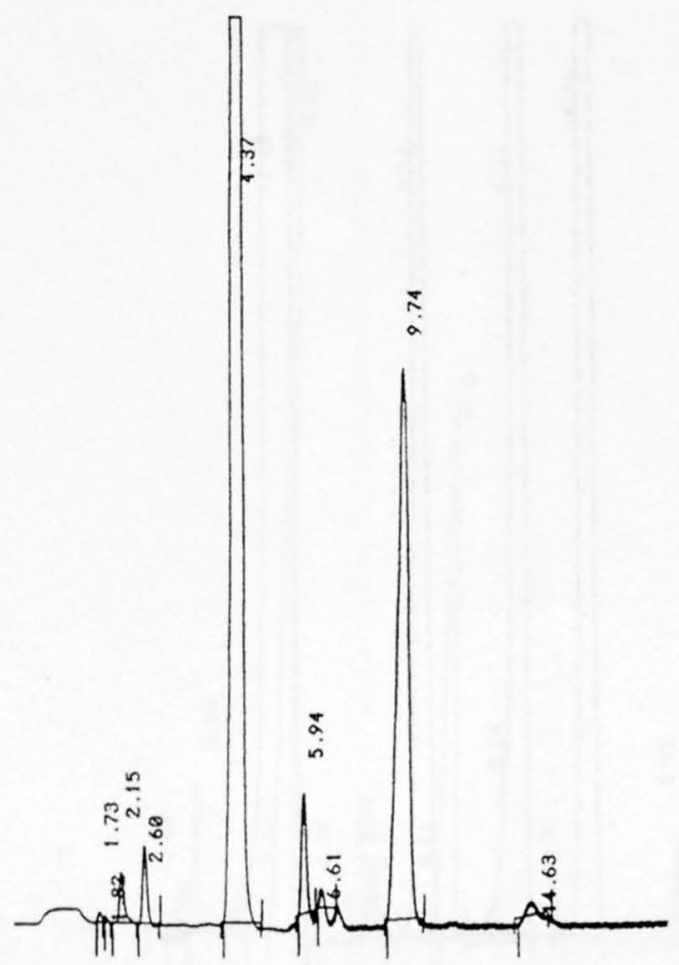

INEL 1 WS, 6/12/95, ID44014.RAW, No. 19

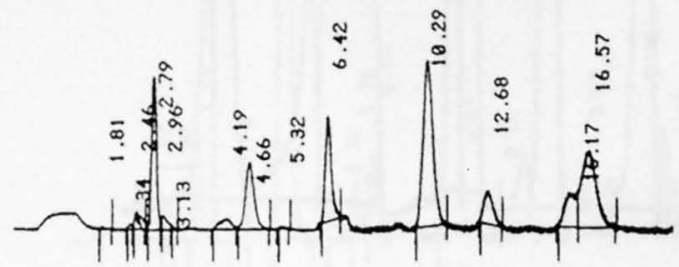

IET Disposal, 7/18/96, ID39010.RAW, No. 18

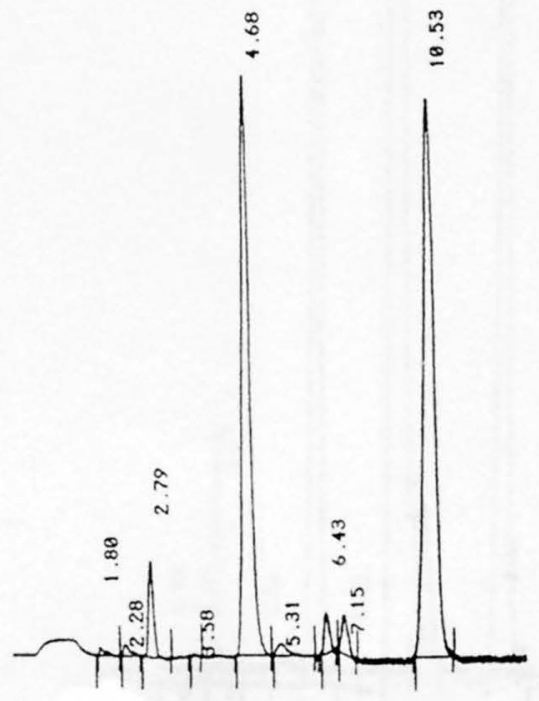

Leo Rogers 1, 7/17/96, ID37015.RAW, No. 20 


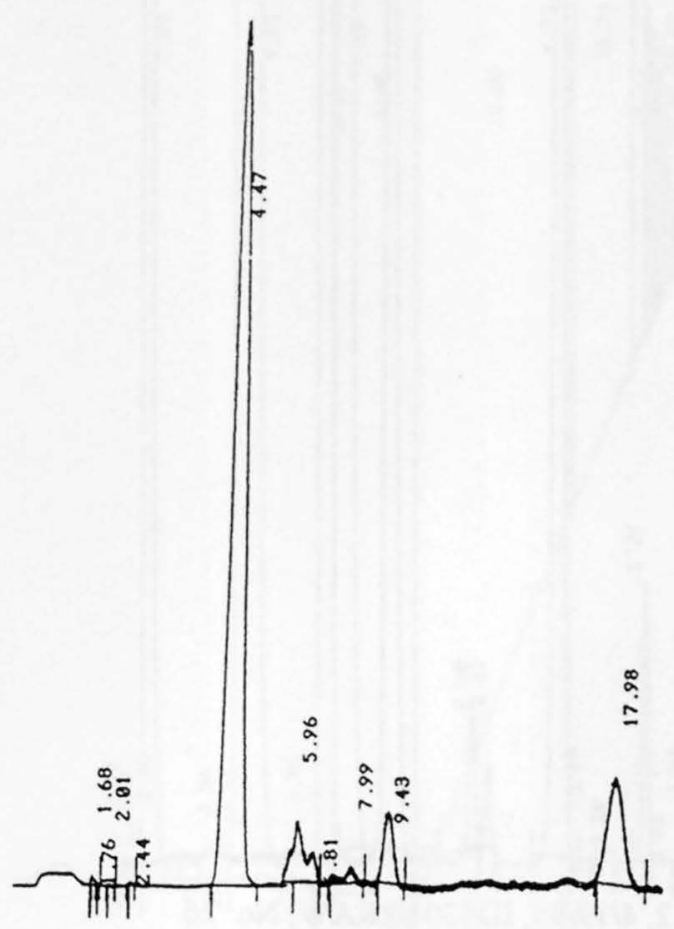

NPR Test, 4/17/95, ID53009.RAW, No. 21

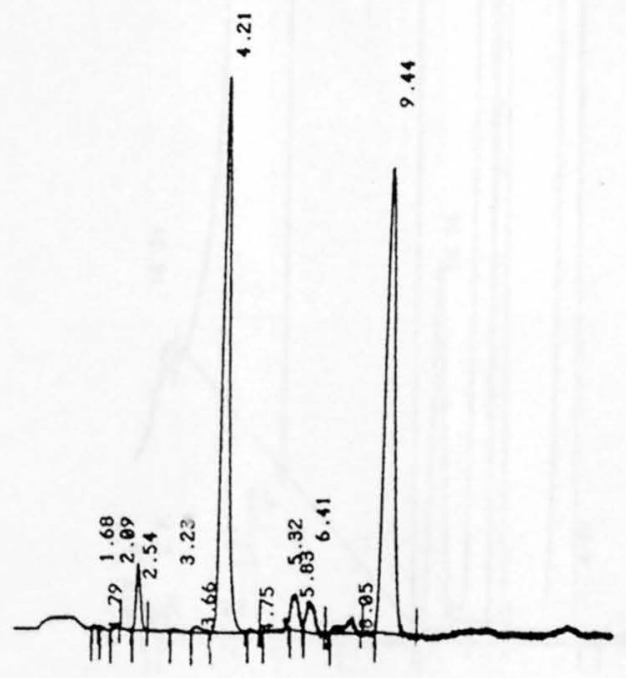

PSTF Test, 10/13/94, ID51015.RAW, No. 23

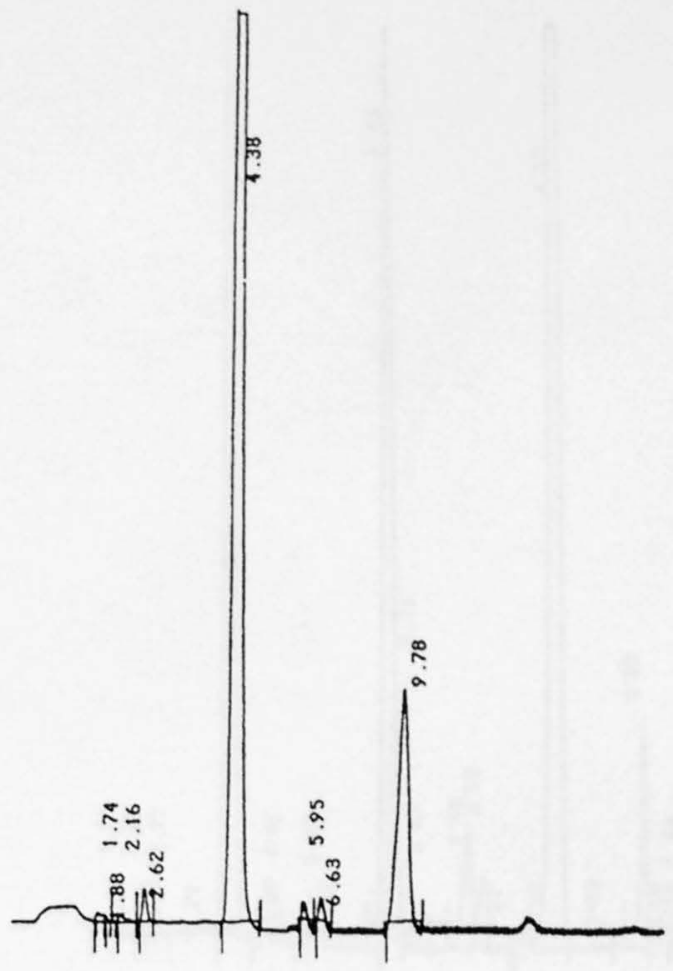

NPR Test, 10/10/96, ID46010.RAW, No. 22

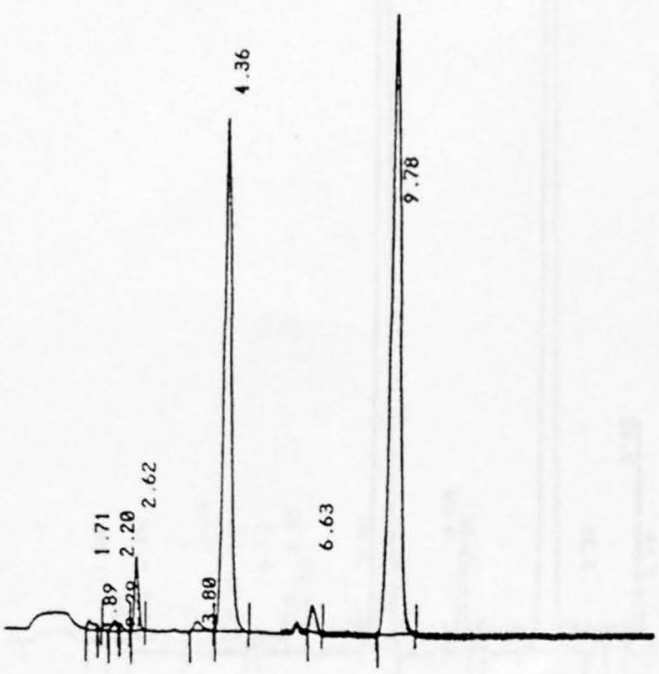

PSTF Test, 10/14/96, ID42015.RAW, No. 24 


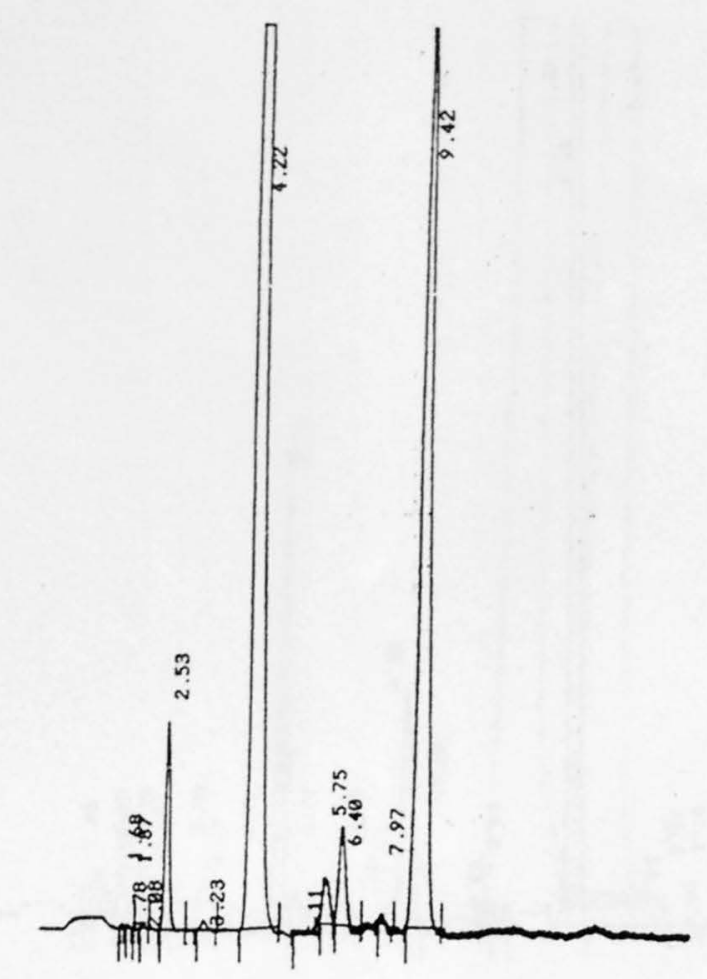

P\&W 2, 10/25/94, ID51017.RAW, No. 25

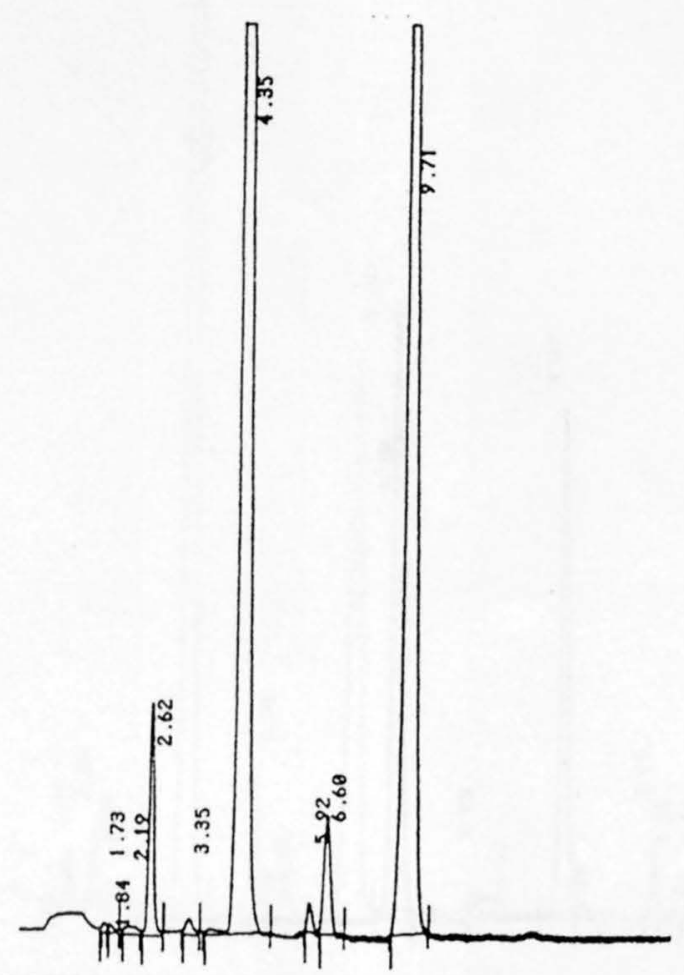

P\&W 2, 10/15/96, ID43010.RAW, No. 27

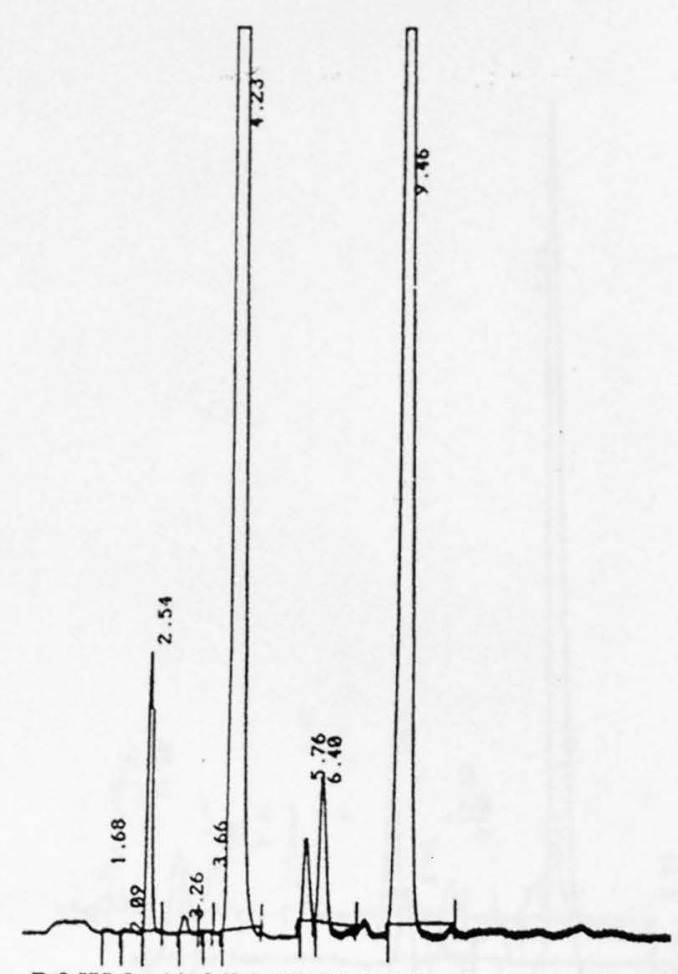

P\&W 2, 4/19/95, ID53010.RAW, No. 26

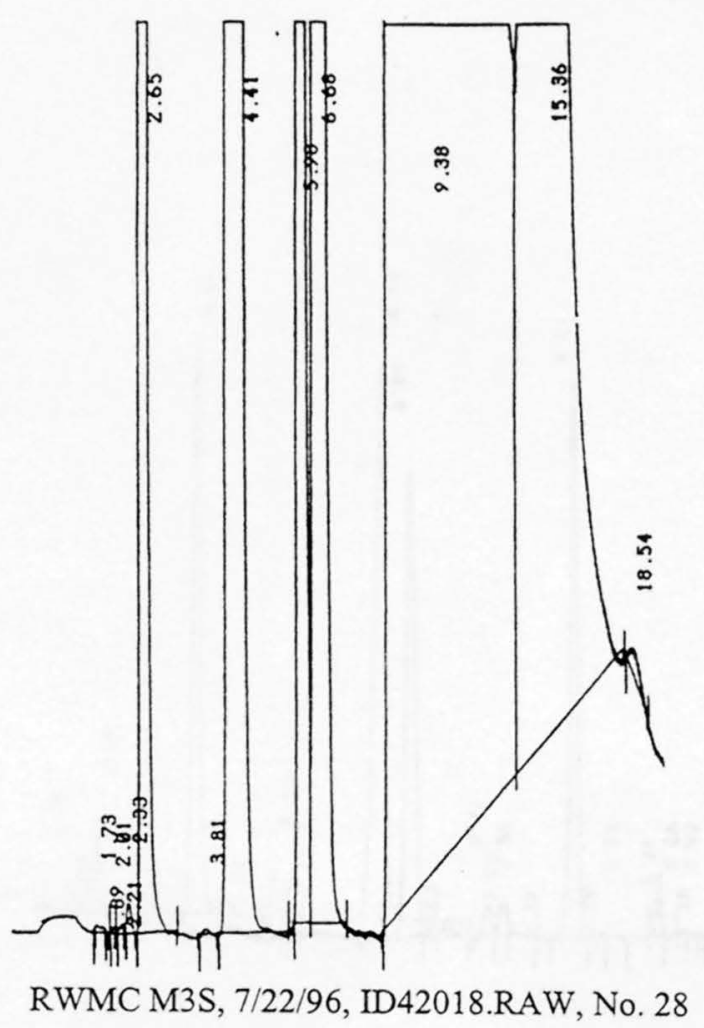




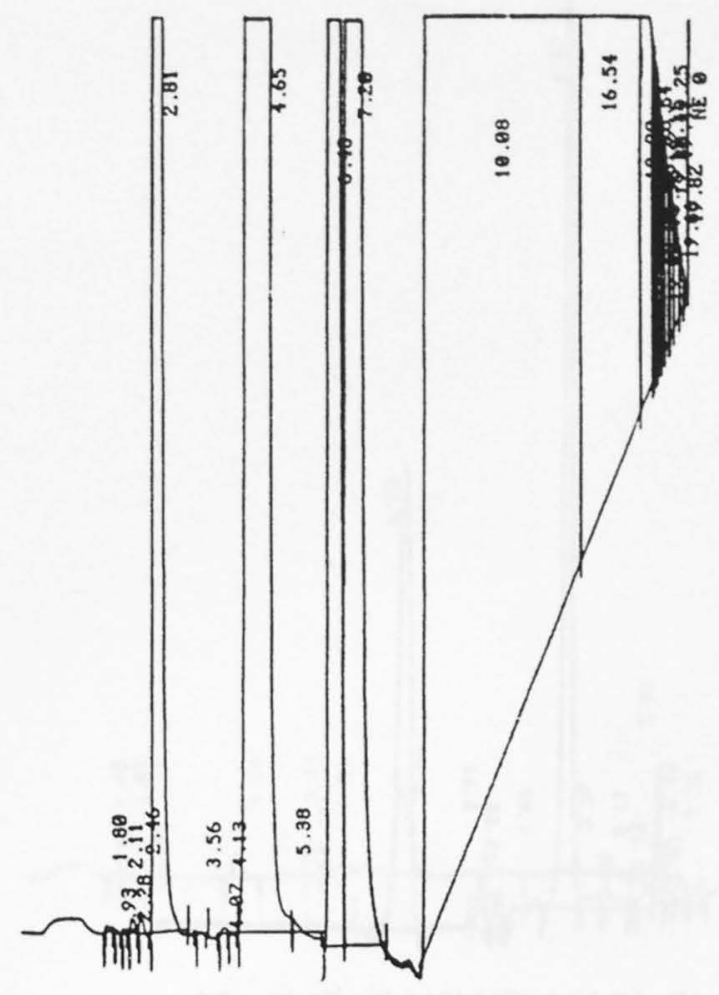

RWMC M7S, 7/22/96, ID39015.RAW, No. 29

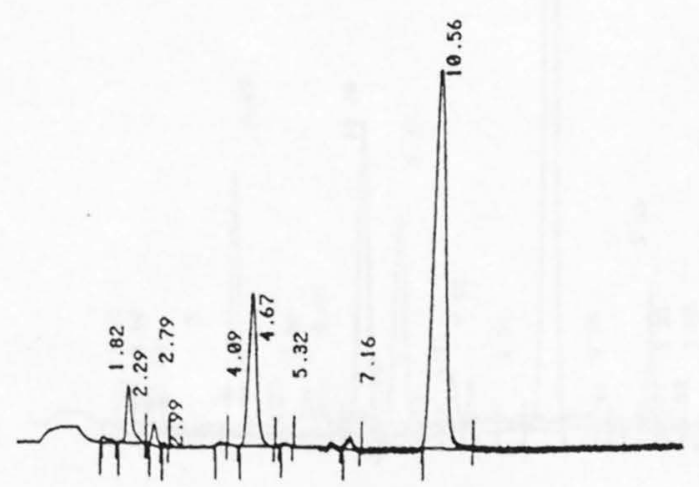

Site 9, 7/22/96, ID41015.RAW, No. 31

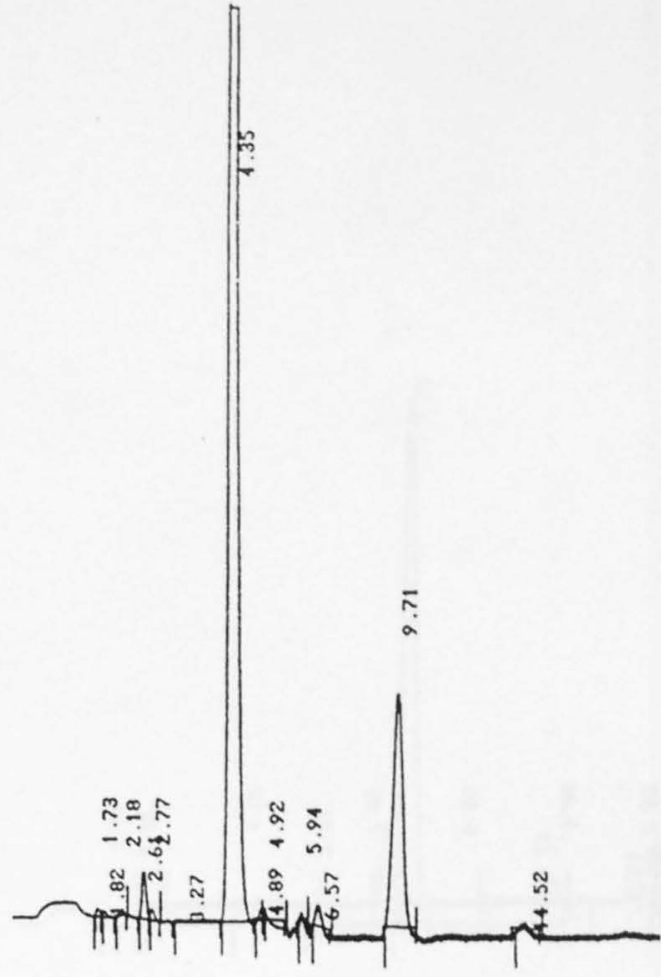

Site 4, 10/6/96, ID44010.RAW, No. 30

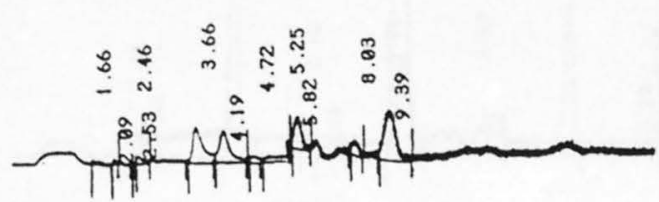

Site 14, 11/13/94, ID51014.RAW, No. 32 


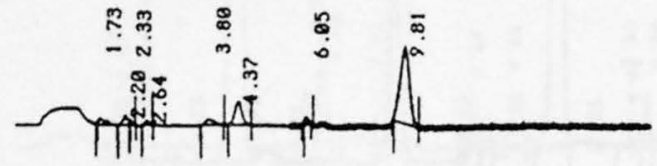

Site 14, 10/14/96, ID42010.RAW, No. 33

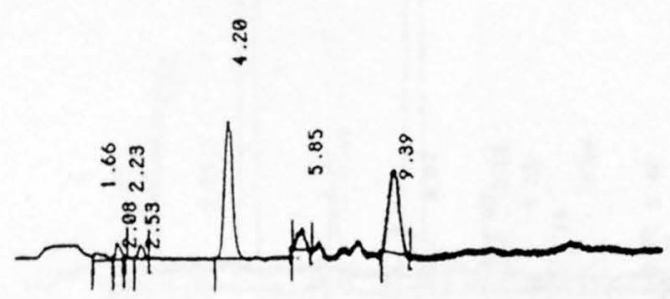

Site 19, 7/21/94, ID50018.RAW, No. 35

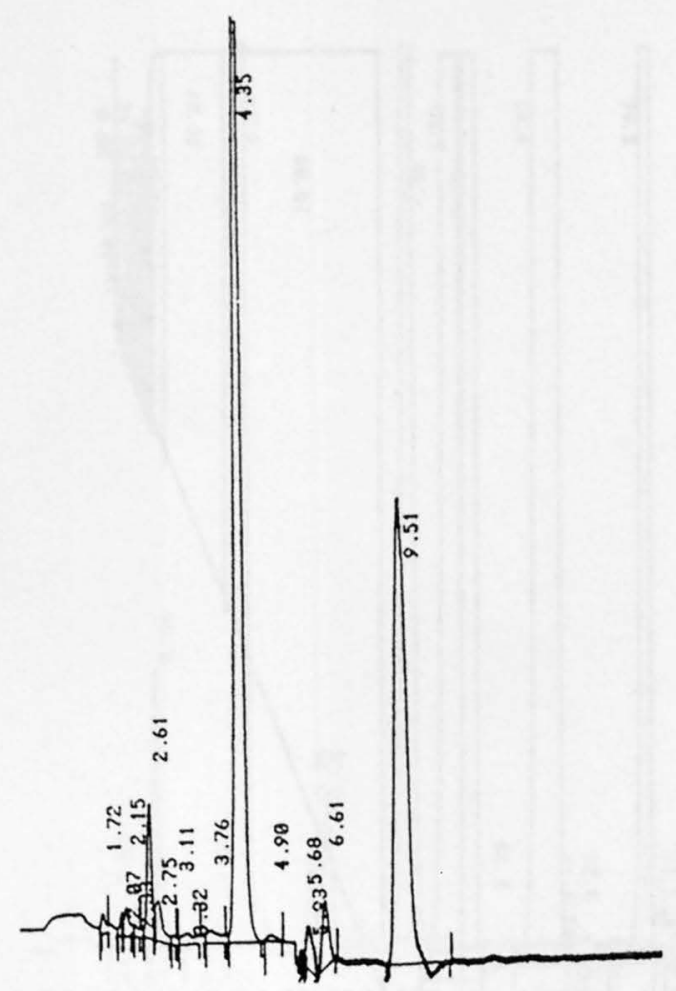

Site 17, 6/16/95, ID44011.RAW, No. 34

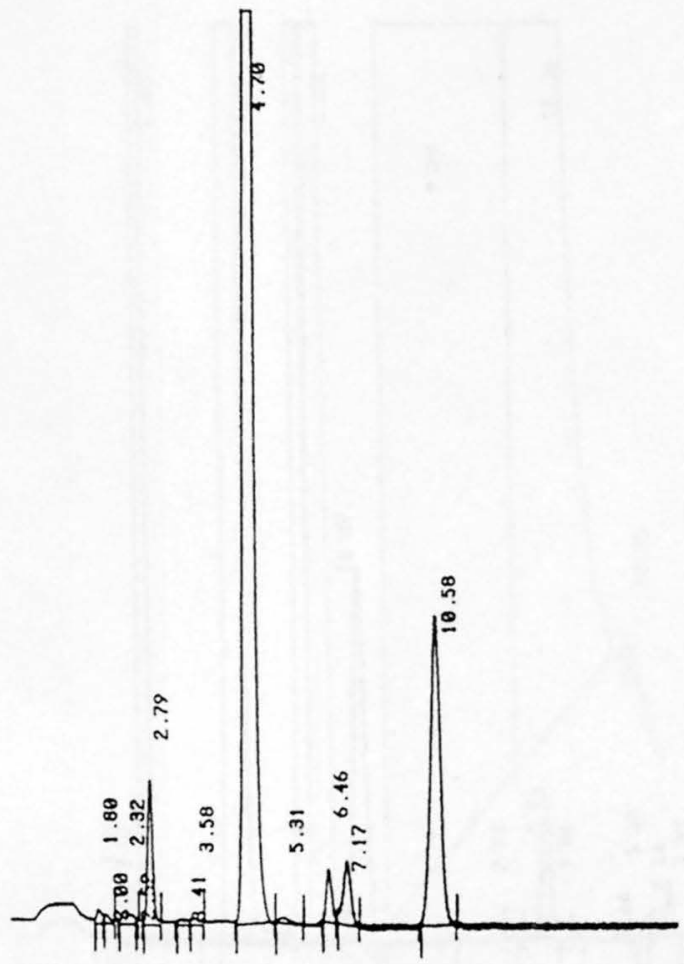

Site 19, 7/16/96, ID40014.RAW, No. 36 


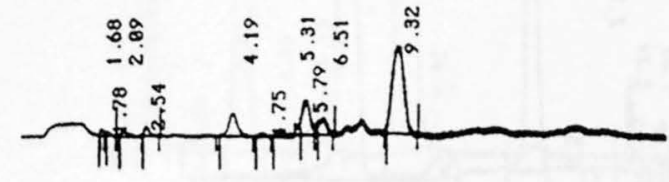

TAN Exploration, 10/13/94, ID49013.RAW, No. 37

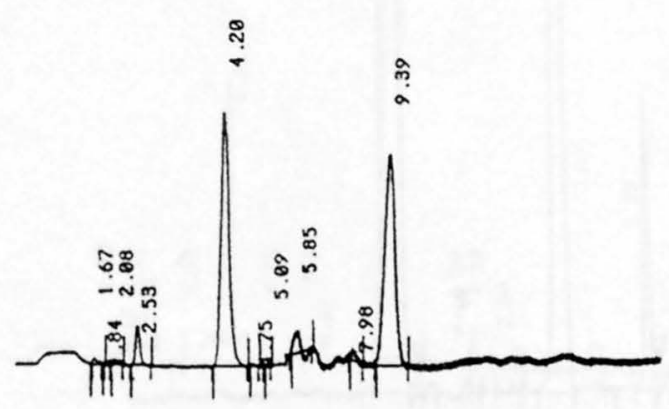

USGS 1, 10/3/94, ID50019.RAW, No. 39

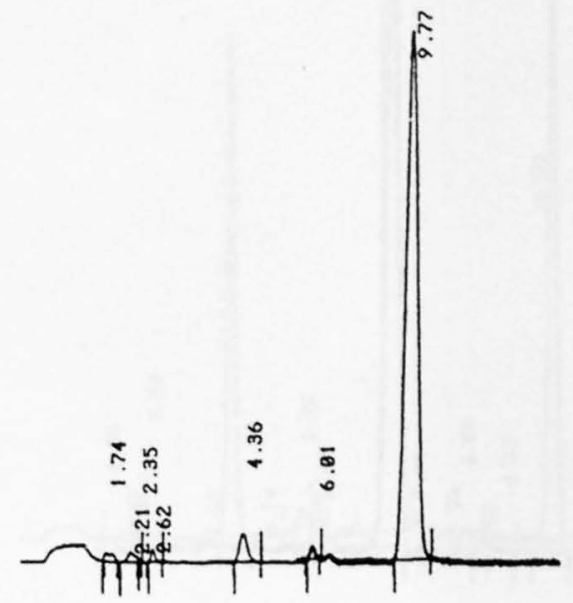

TAN Exploration, 10/14/96, ID42013.RAW, No. 38

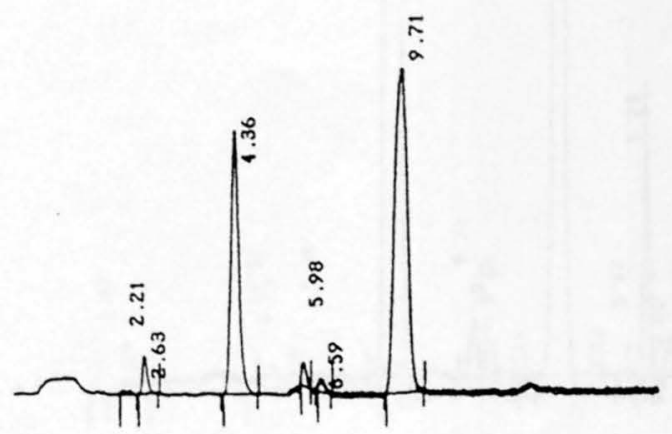

USGS 1, 10/9/96, ID47015.RAW, No. 40 


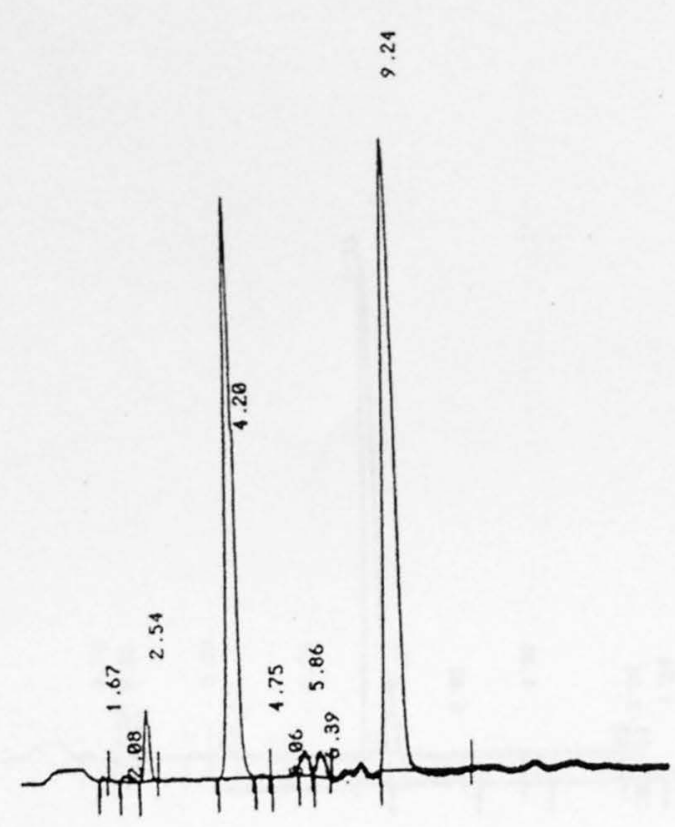

USGS 2, 10/19/94, ID49011.RAW, No. 41

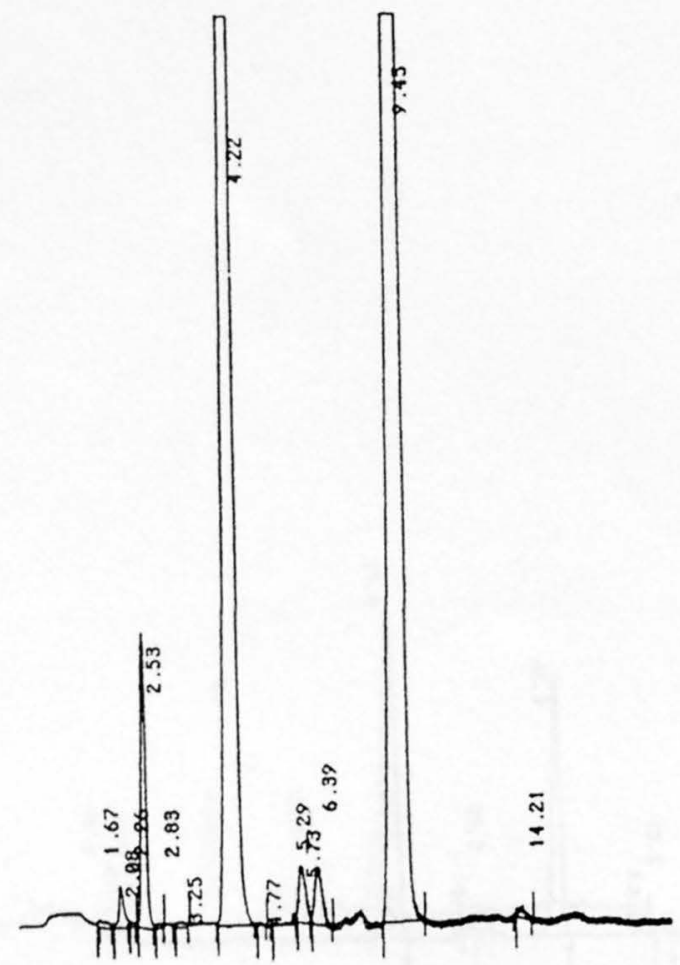

USGS 4, 10/24/94, ID50020.RAW, No. 43

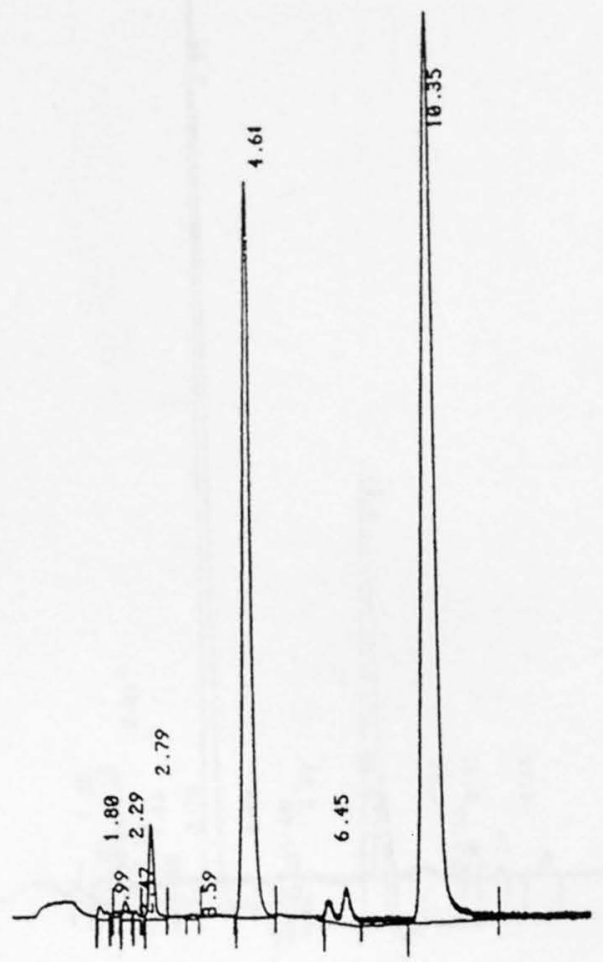

USGS 2, 7/17/96, ID37017.RAW, No. 42

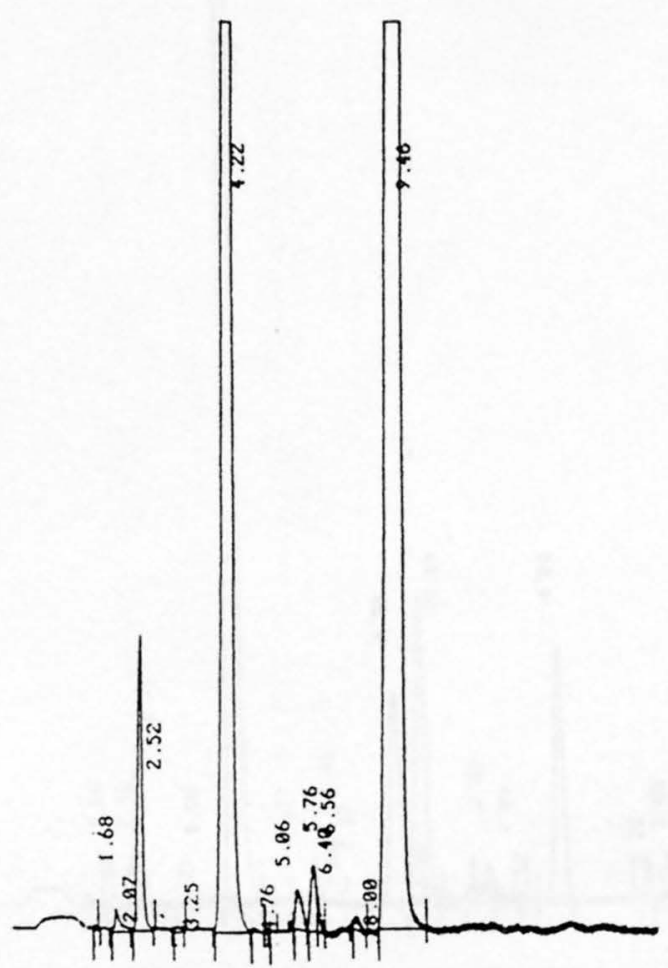

USGS 4, 4/19/95, ID53011.RAW, No. 44 


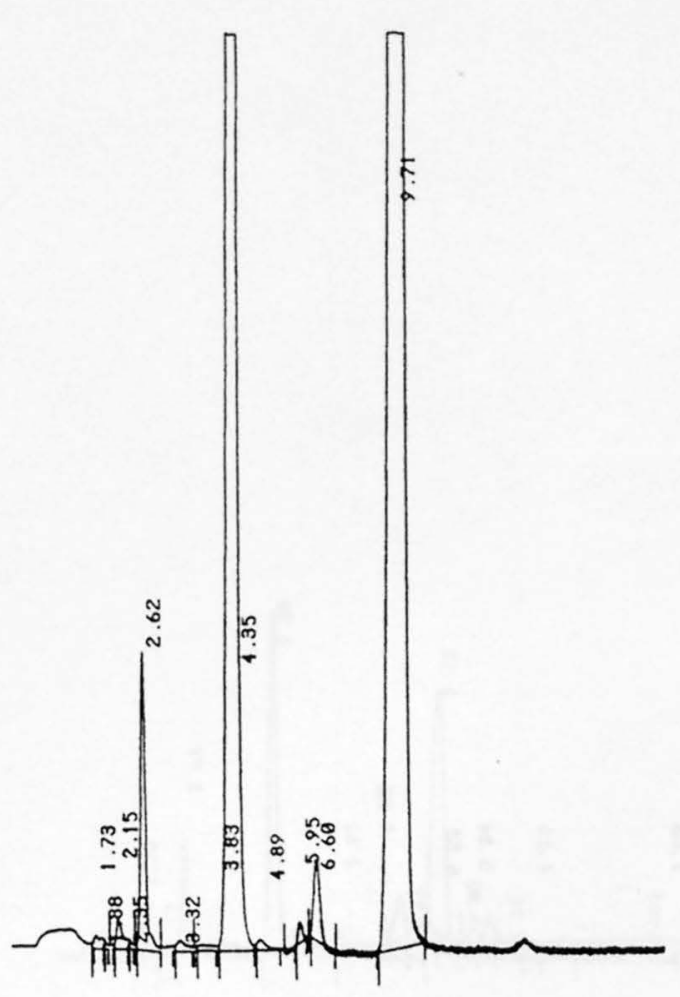

USGS 4, 10/15/96, ID43016.RAW, No. 45

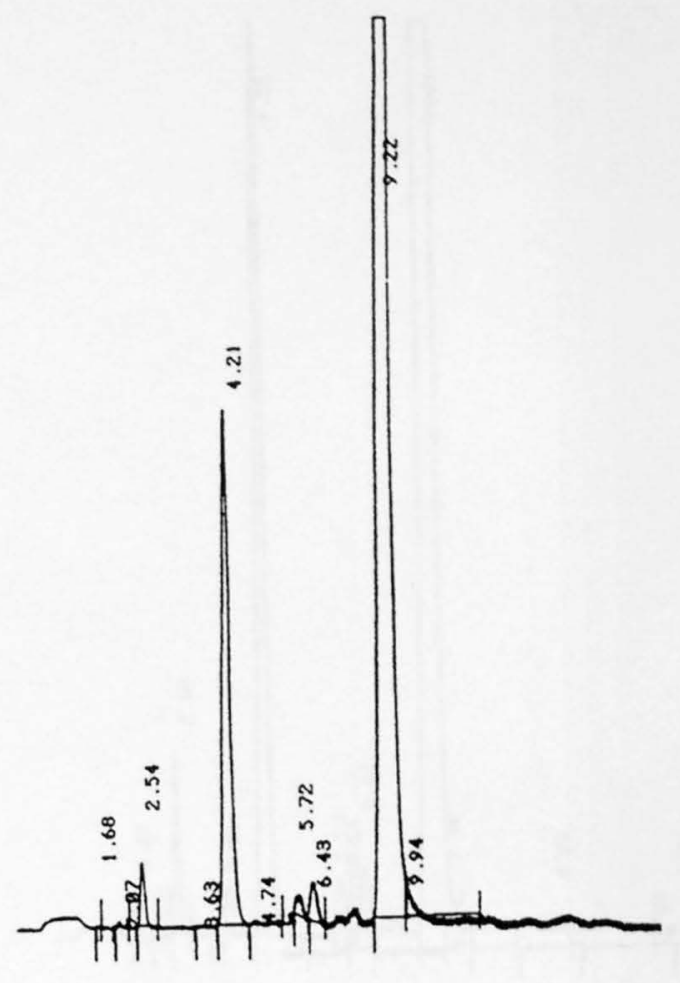

USGS 5, 10/12/94, ID51009.RAW, No. 46

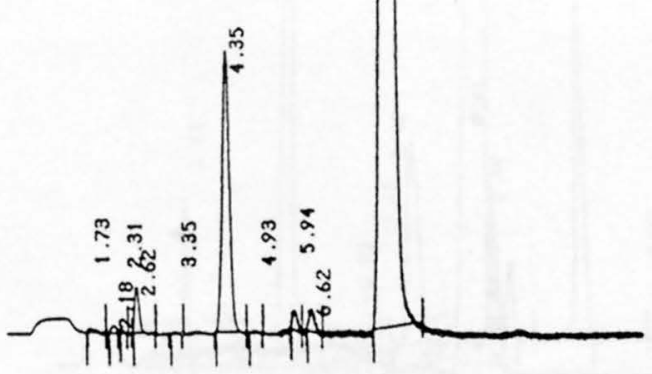

USGS 5, 10/10/96, ID48014.RAW, No. 47

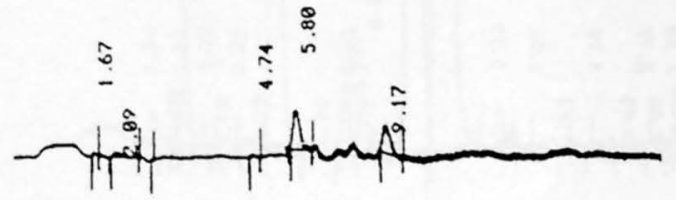

USGS 5, 7/19/94, ID49015.RAW, No. 48

29 


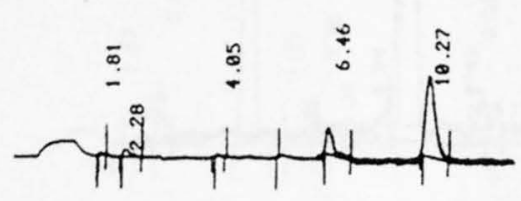

USGS 6, 7/18/96, ID37023.RAW, No. 49

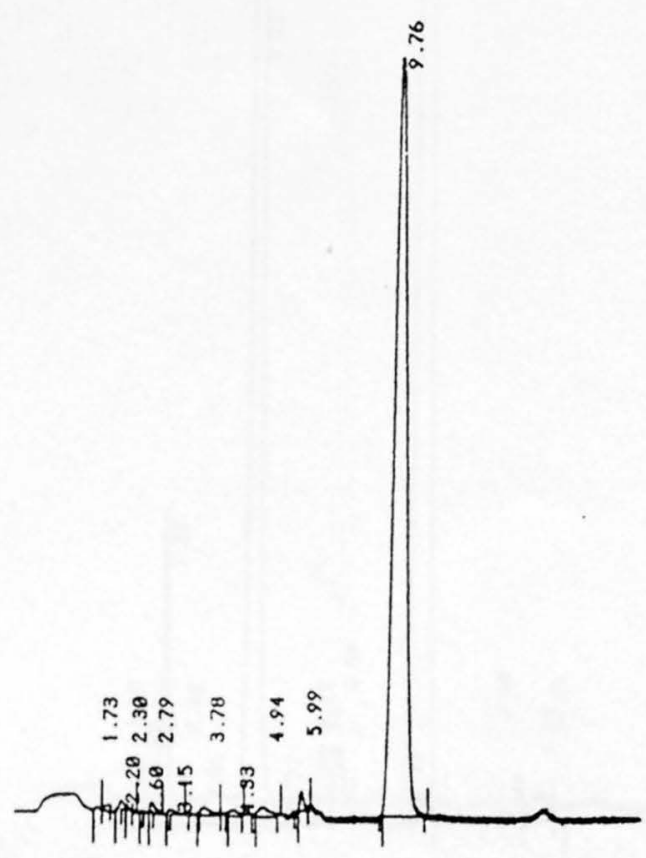

USGS 7, 10/14/96, ID42020.RAW, No. 51

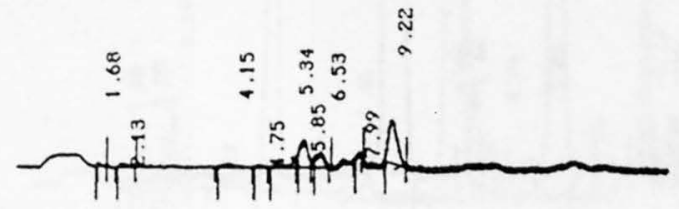

USGS 7, 10/14/94, ID49014.RAW, No. 50

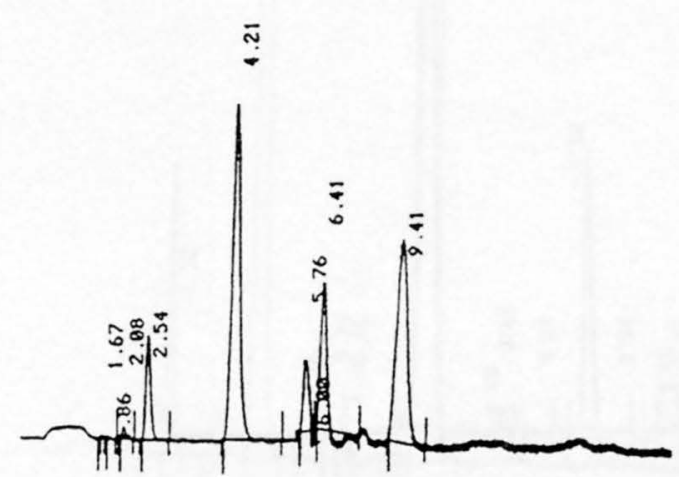

USGS 8, 10/4/94, ID51010.RAW, No. 52 


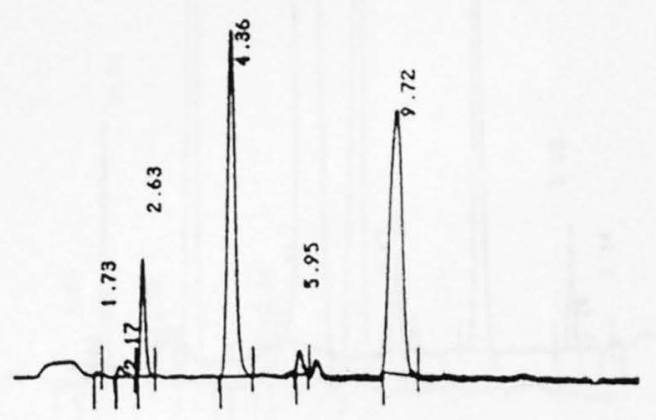

USGS 8, 10/8/96, ID48012.RAW, No. 53

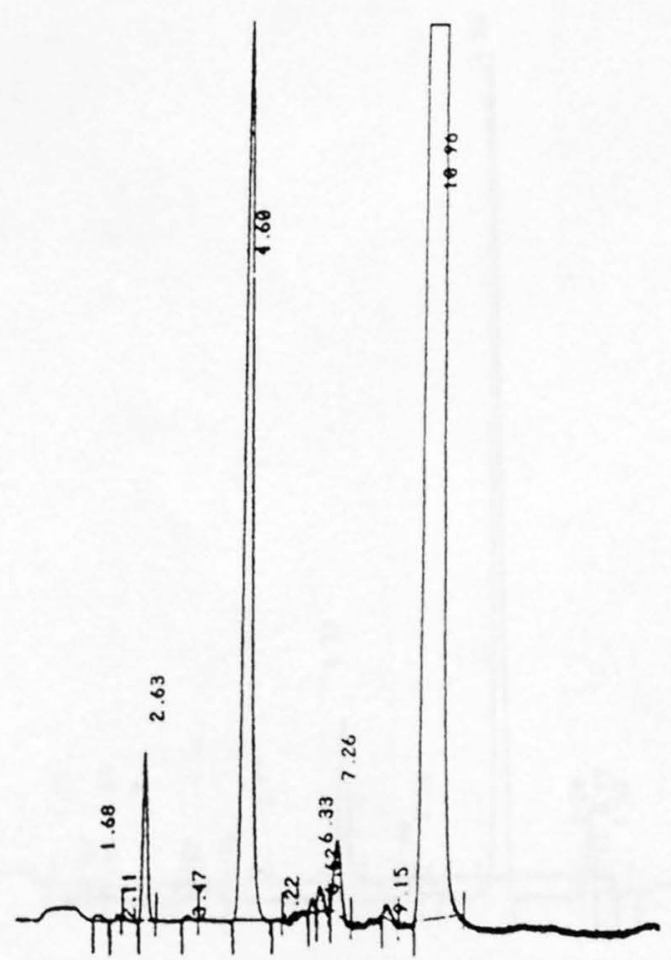

USGS 9, 4/20/95, SC03019.RAW, No. 55

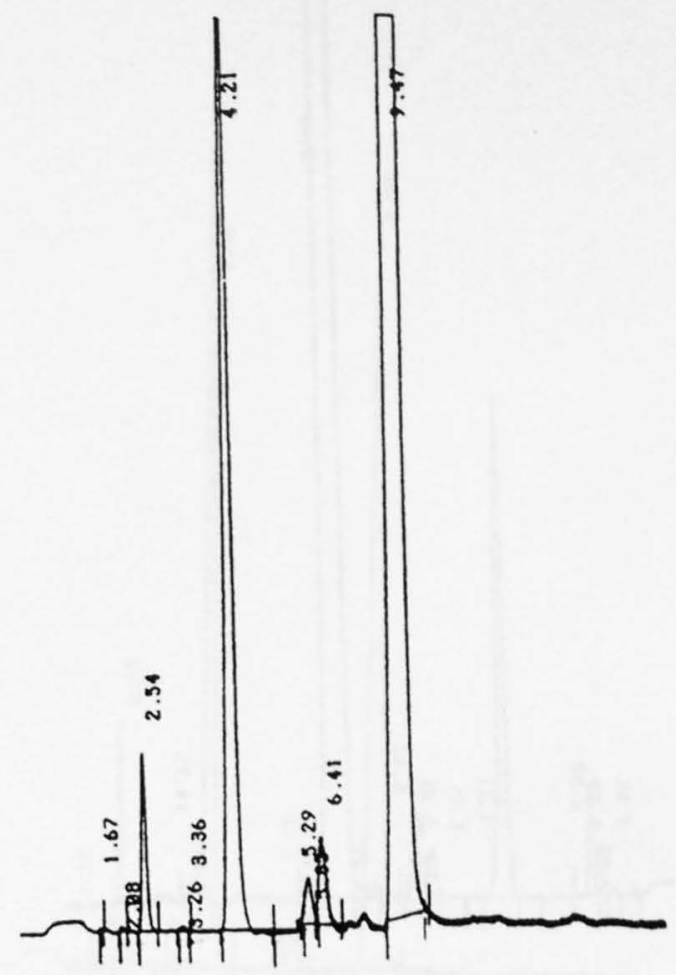

USGS 9, 10/4/94, ID52012.RAW, No. 54

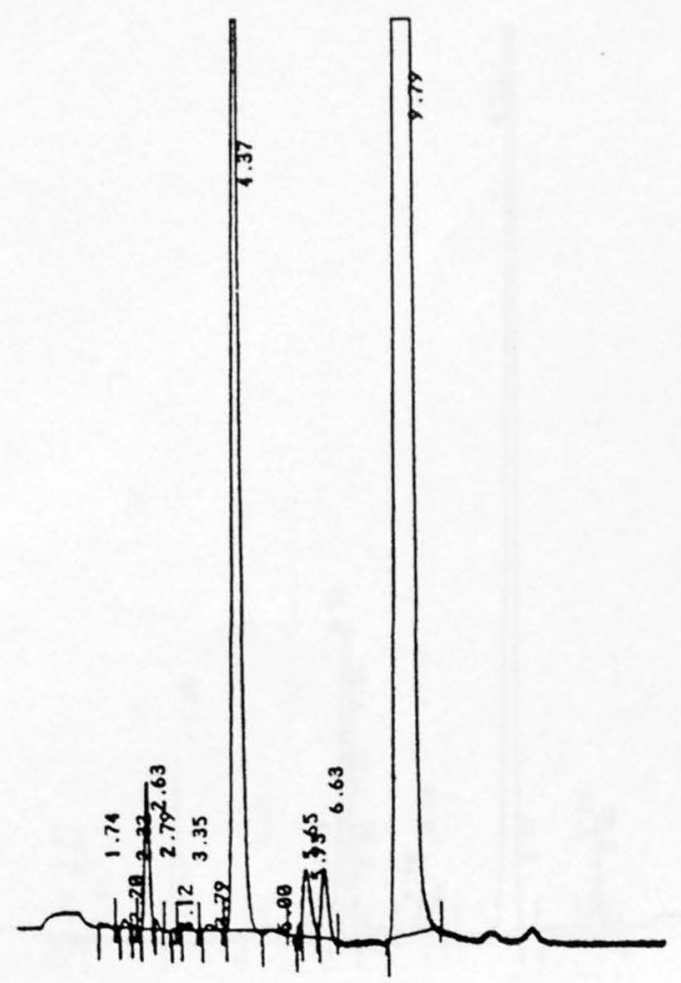

USGS 9, 10/11/96, ID47021.RAW, No. 56 


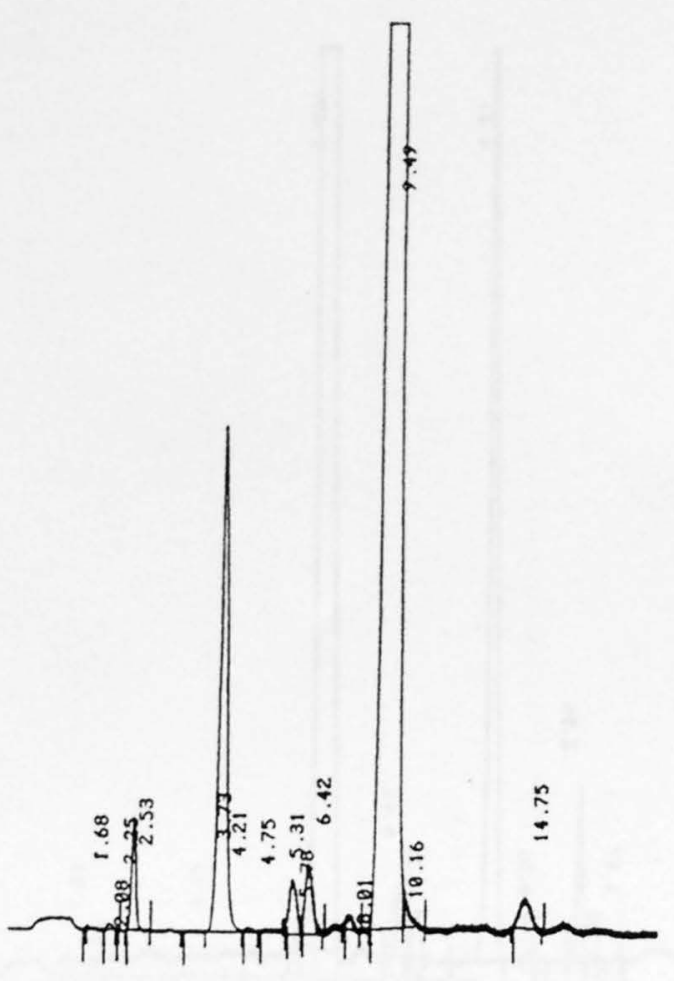

USGS 11, 4/20/95, ID53012.RAW, No. 57

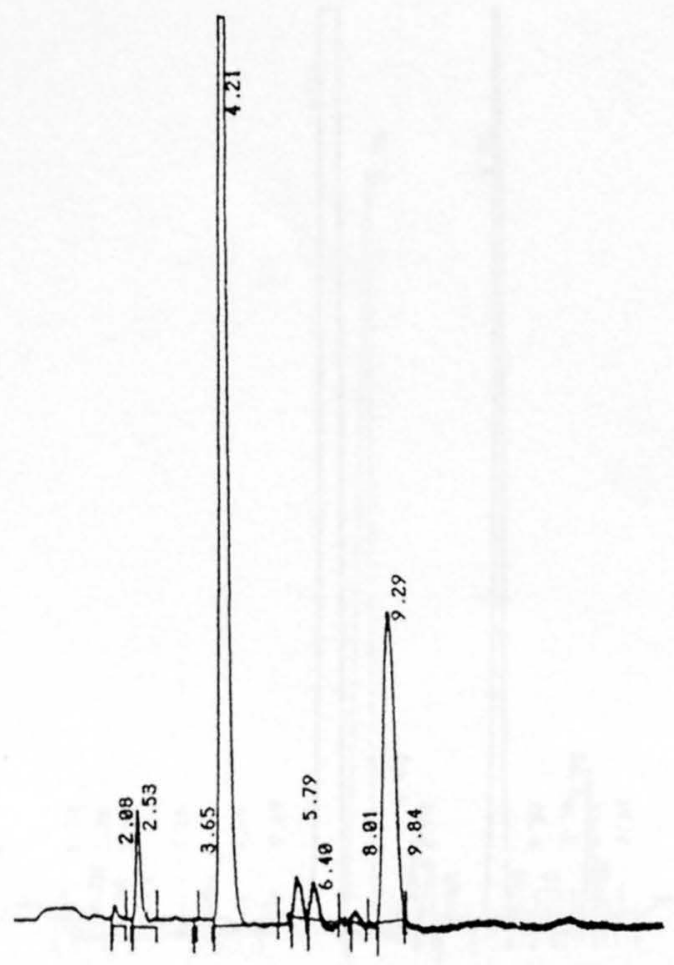

USGS 12, 10/27/94, ID51011.RAW, No. 59

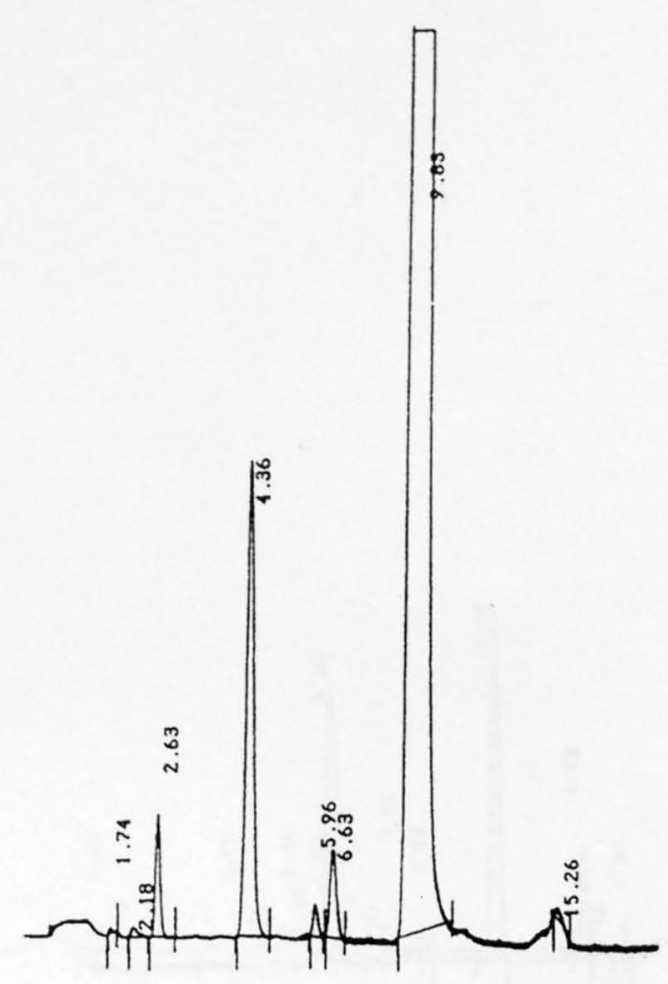

USGS 11, 10/9/96, ID47011.RAW, No. 58

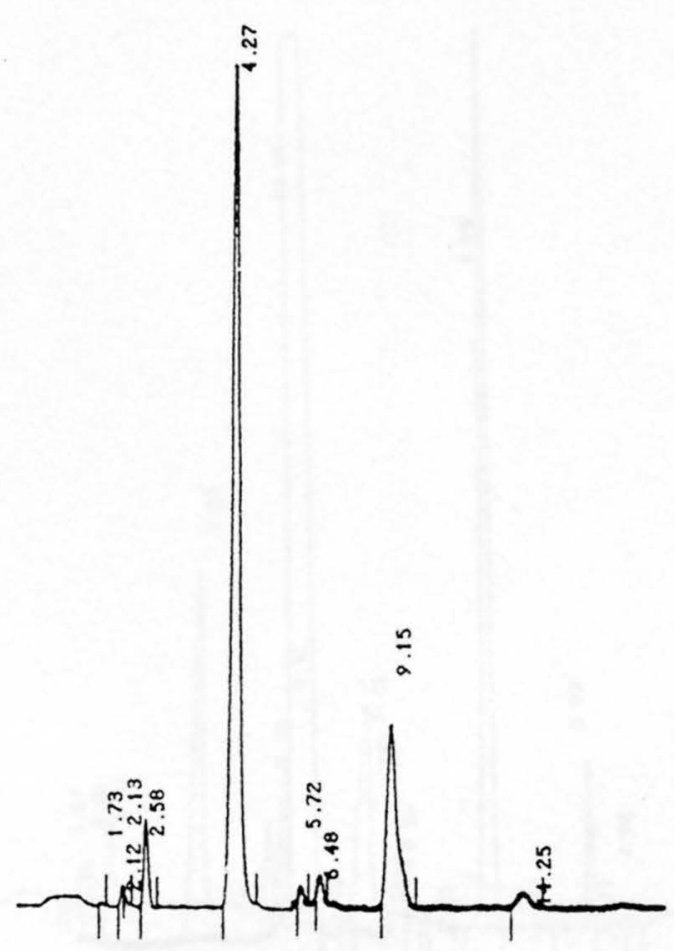

USGS 12, 6/14/95, ID23013.RAW, No. 60

32 


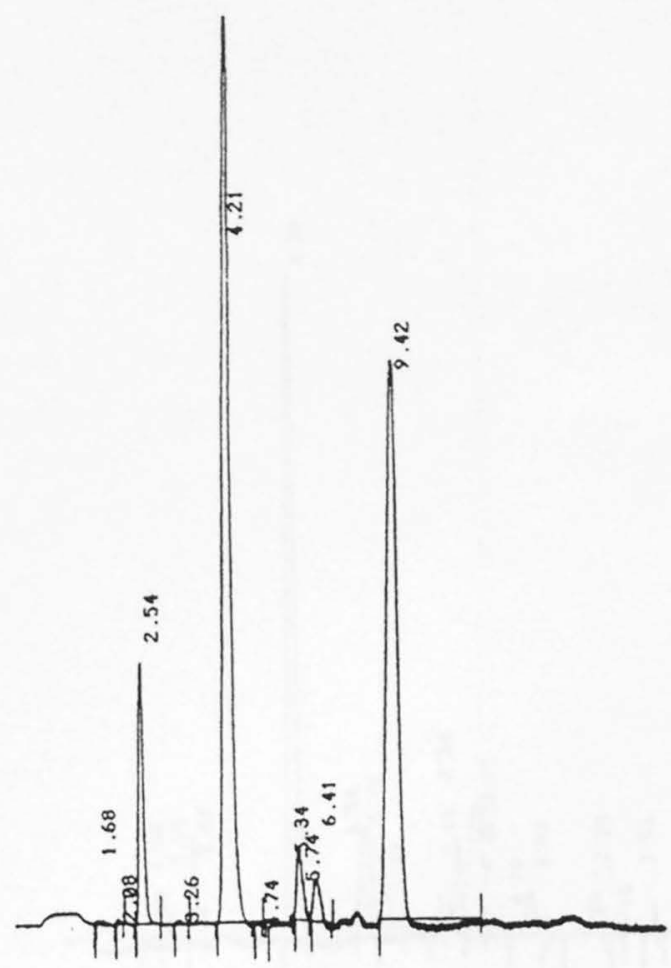

USGS 14, 10/26/94, ID51012.RAW, No. 61

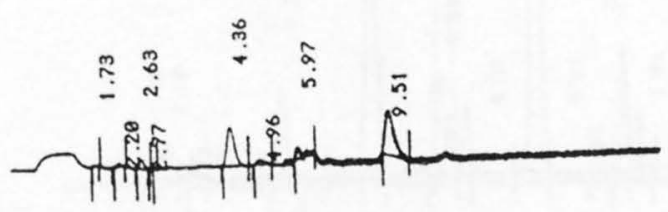

USGS 15, 6/14/95, ID45011.RAW, No. 63

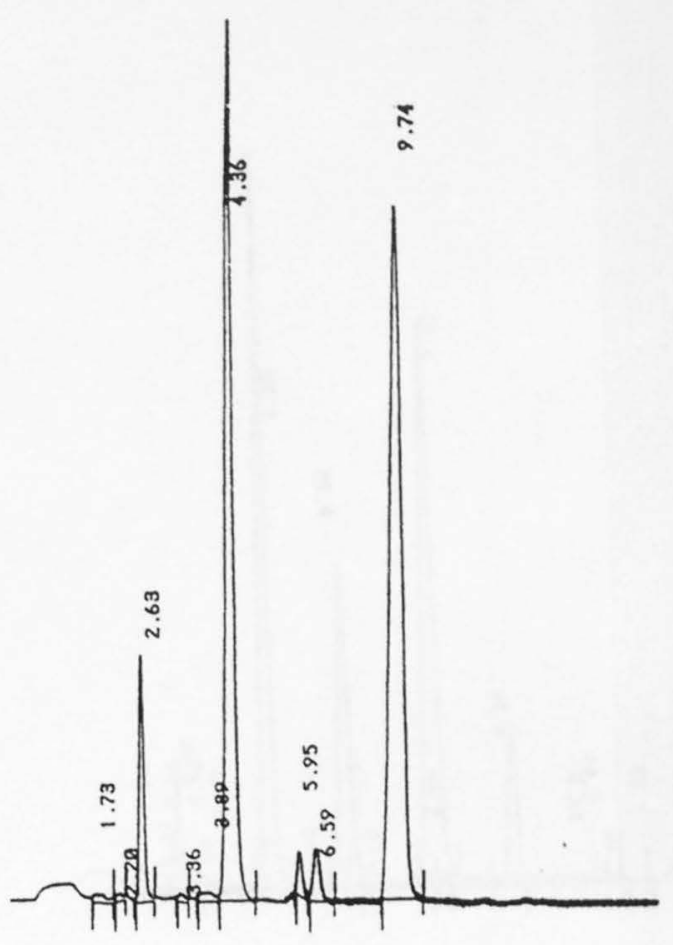

USGS 14, 10/9/96, ID47009.RAW, No. 62

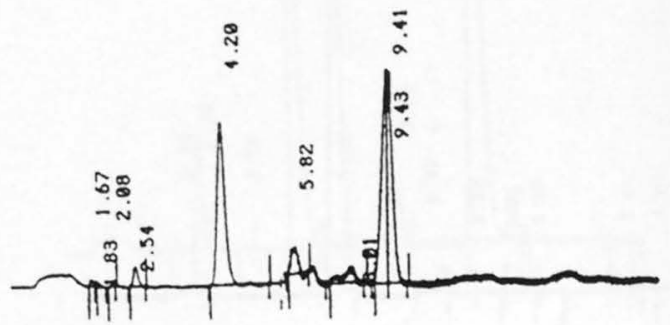

USGS 17, 10/27/94, ID52011.RAW, No. 64 


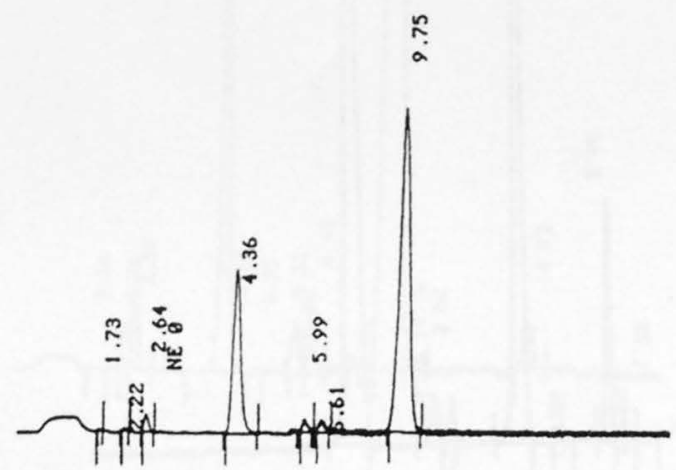

USGS 17, 6/13/95, ID45010.RAW, No. 65

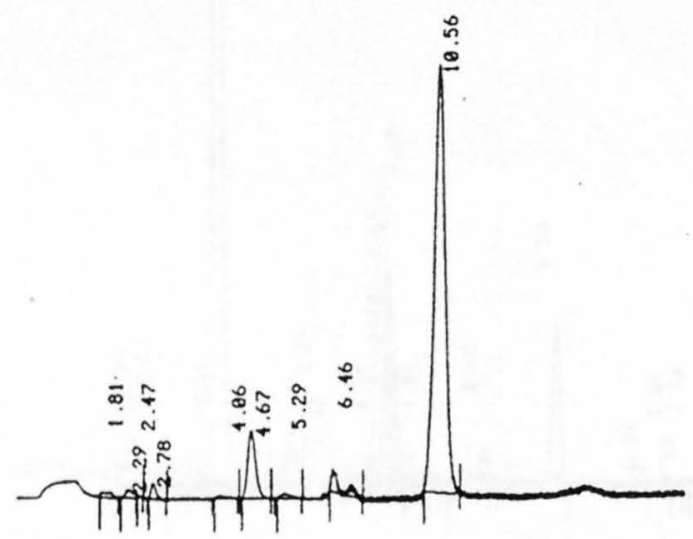

USGS 18, 7/19/96, ID39018.RAW, No. 67

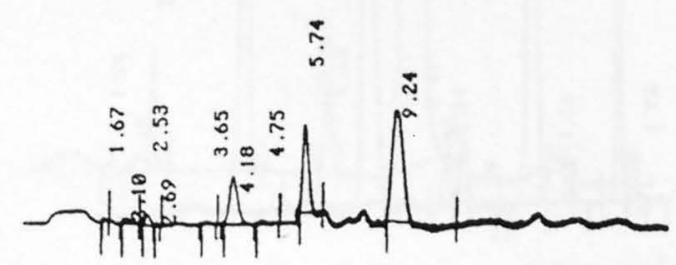

USGS 18, 4/18/94, ID49016.RAW, No. 66

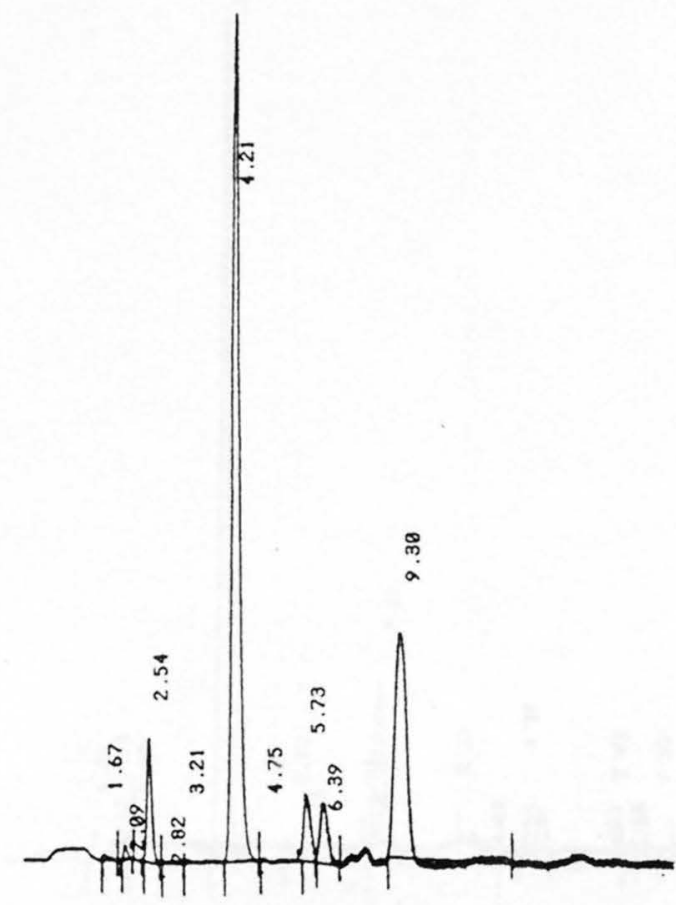

USGS 19, 10/25/94, ID51016.RAW, No. 68 


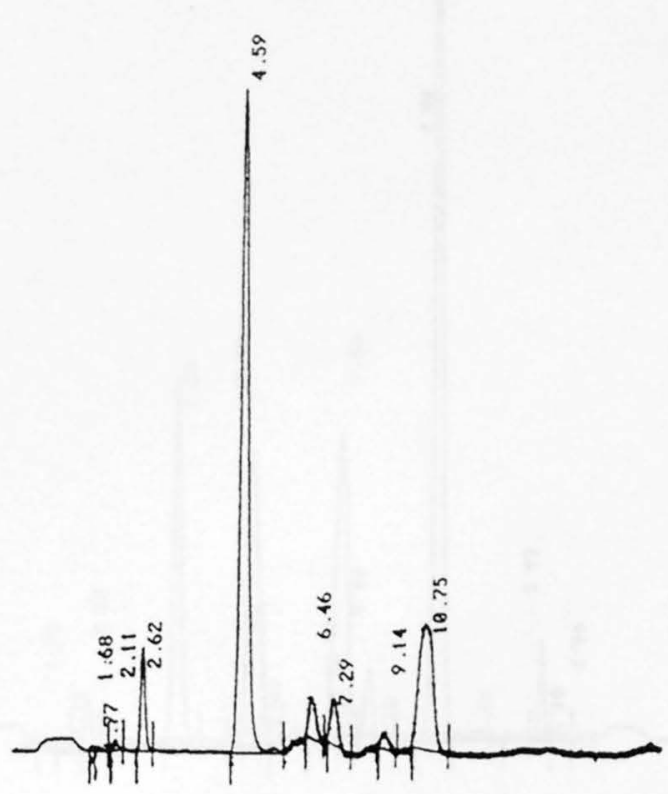

USGS 19, 4/19/95, SC03017.RAW, No. 69

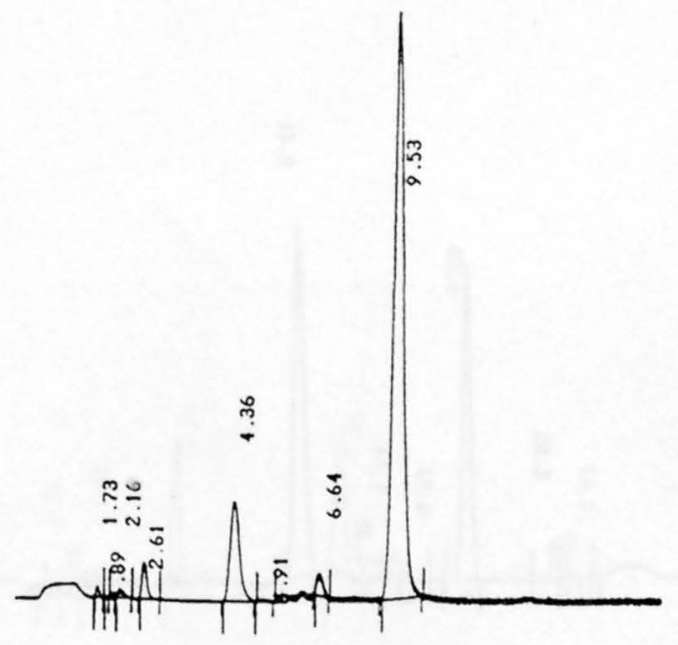

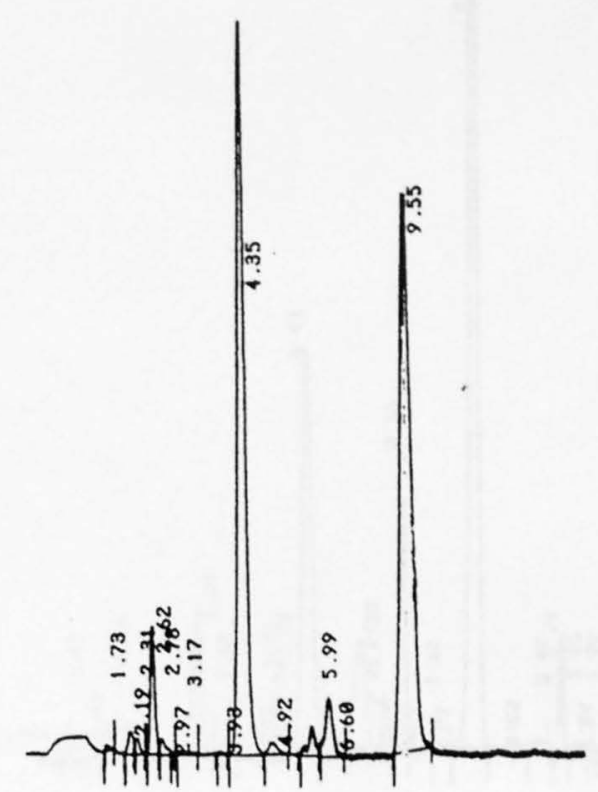

USGS 19, 10/15/96, ID42025.RAW, No. 70

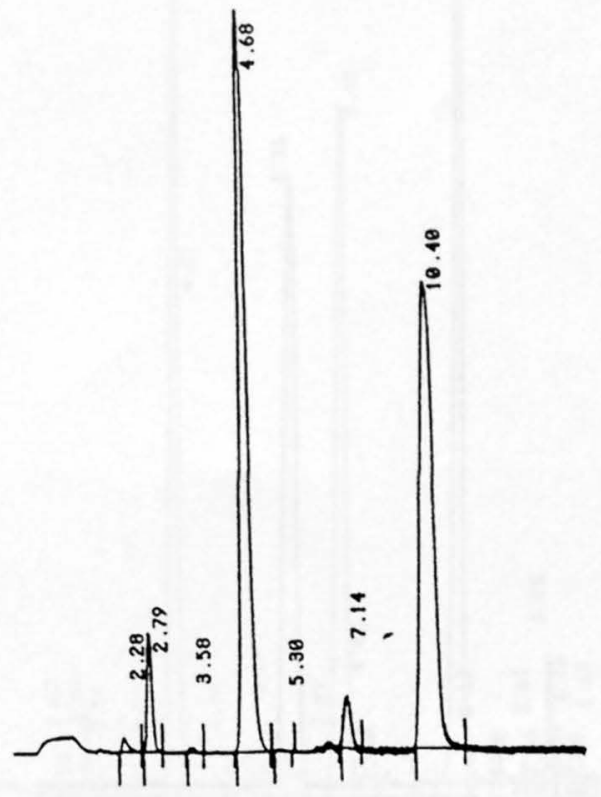

USGS 22, 7/18/96, ID37021.RAW, No. 72 


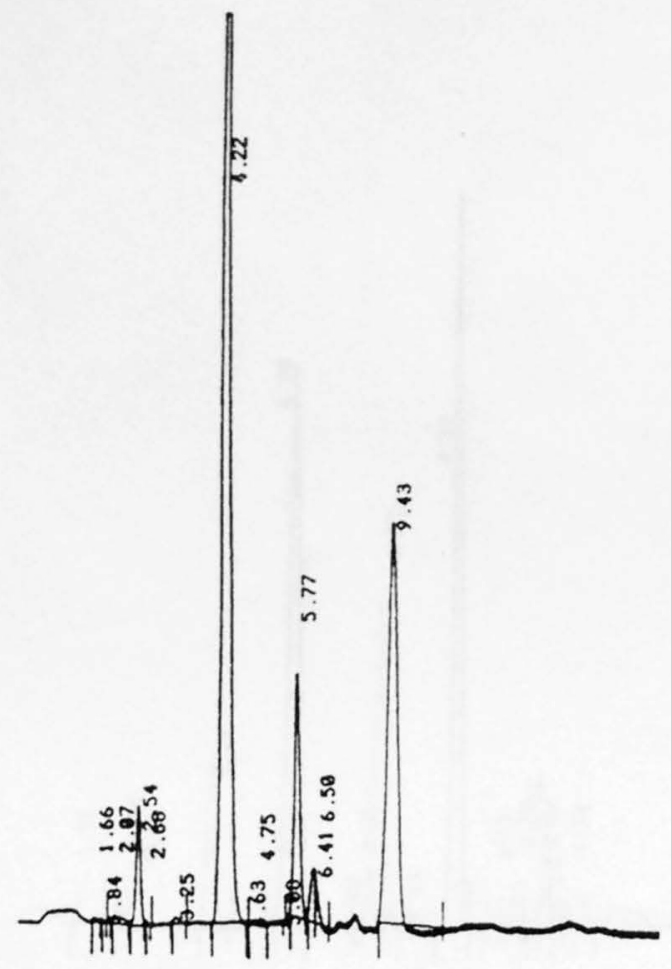

USGS 23, 10/25/94, ID51013.RAW, No. 73

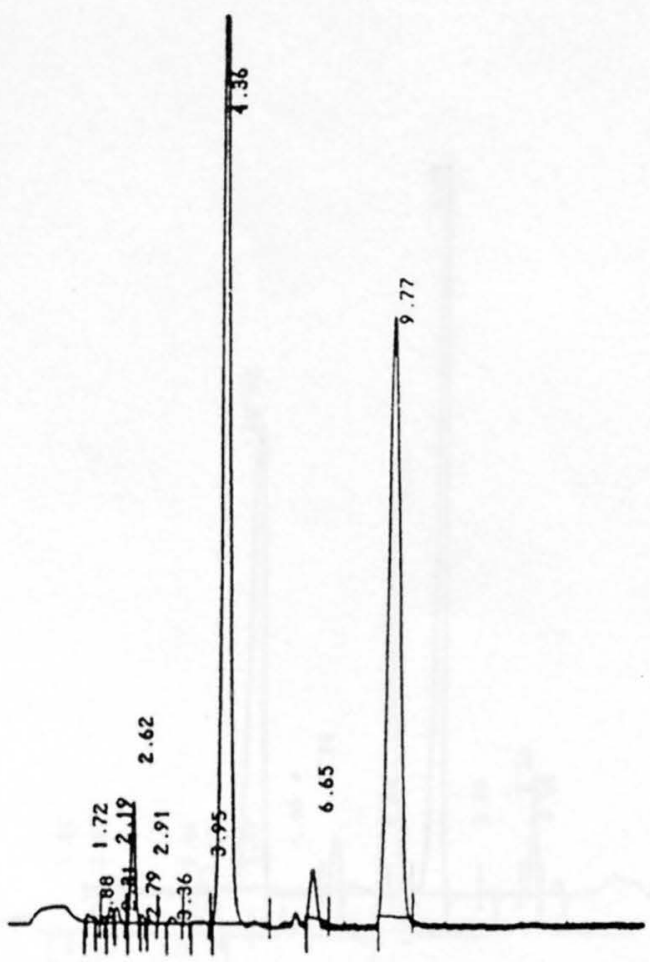

USGS 23, 10/15/96, ID42023.RAW, No. 75

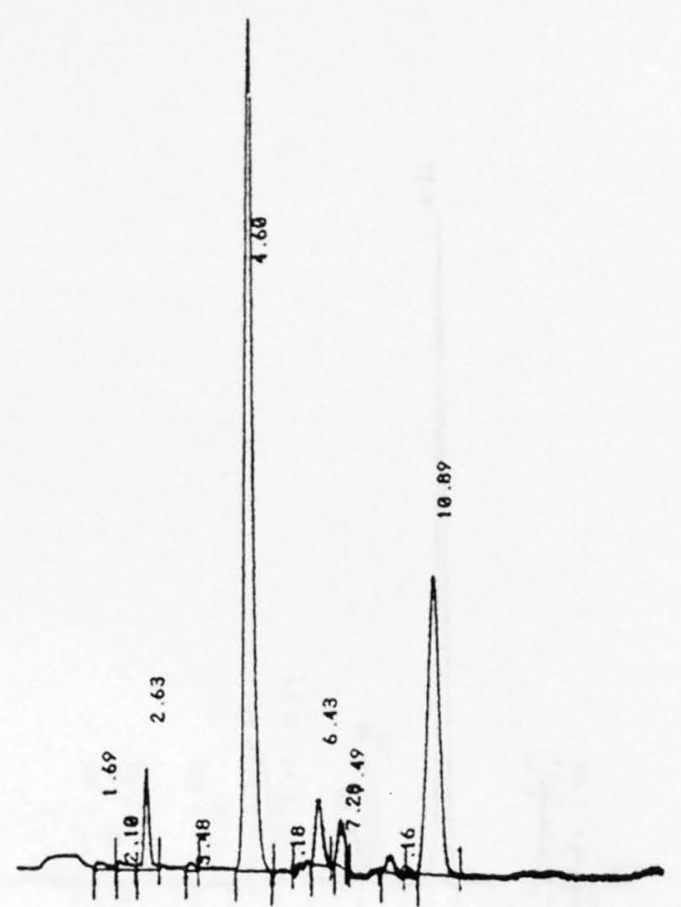

USGS 23, 4/19/95, SC03015.RAW, No. 74

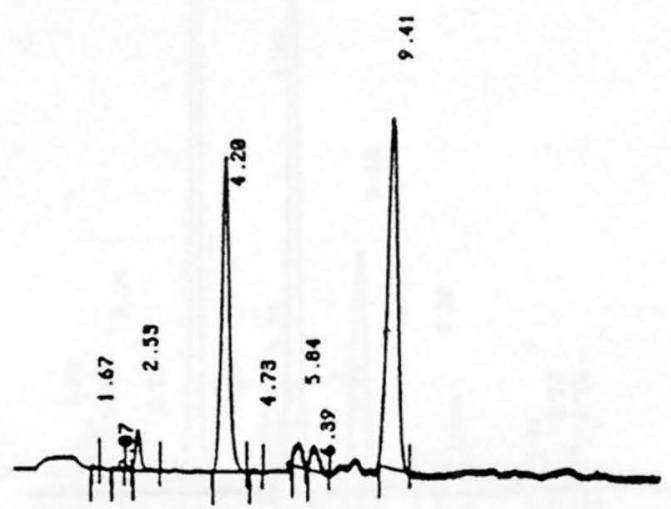

USGS 26, 10/14/94, ID50013.RAW, No. 76 


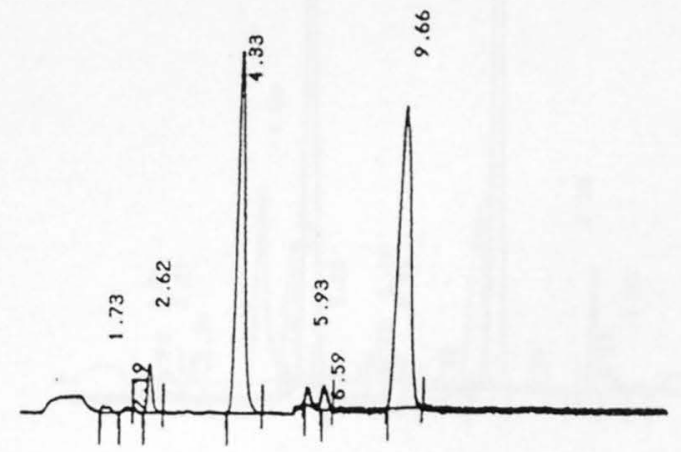

USGS 26, 10/15/96, ID43012.RAW, No. 77

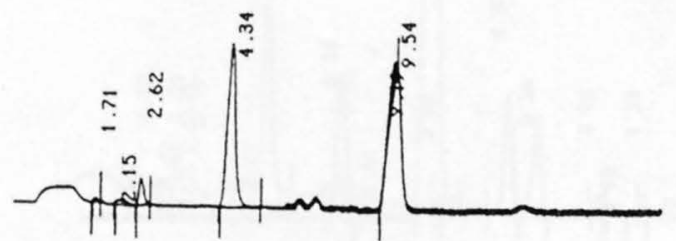

USGS 27, 10/15/96, ID43014.RAW, No. 79

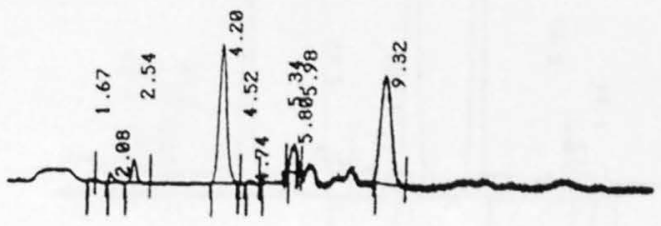

USGS 27, 10/11/94, ID51019.RAW, No. 78

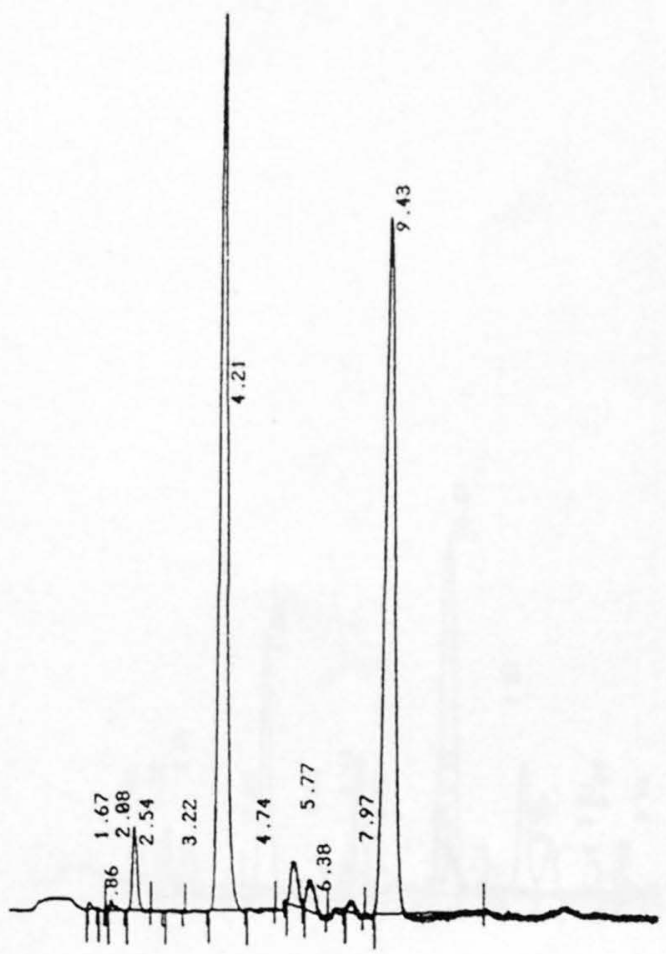

USGS 29, 10/11/94, ID51021.RAW, No. 80 


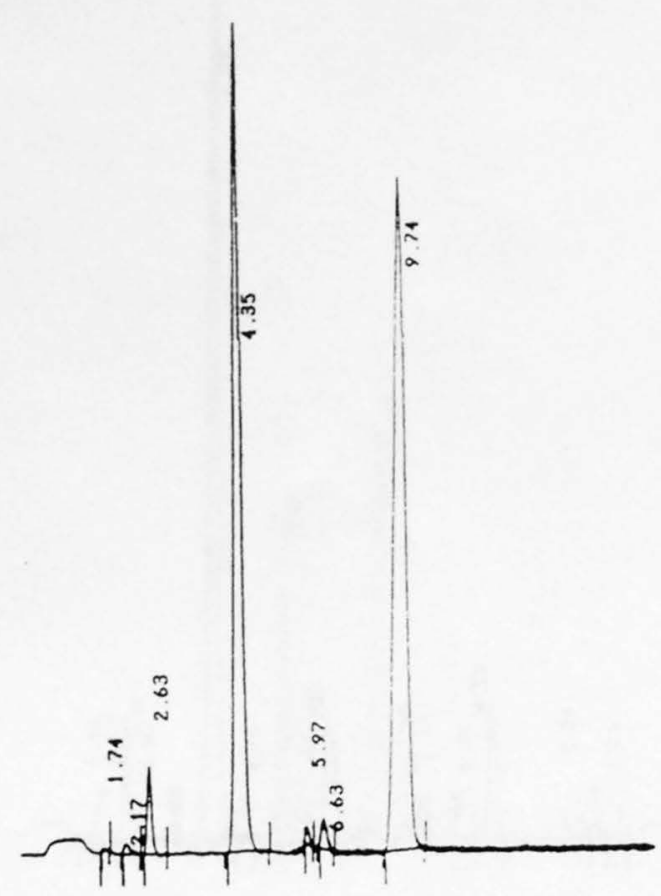

USGS 29, 6/15/95, ID45019.RAW, No. 81

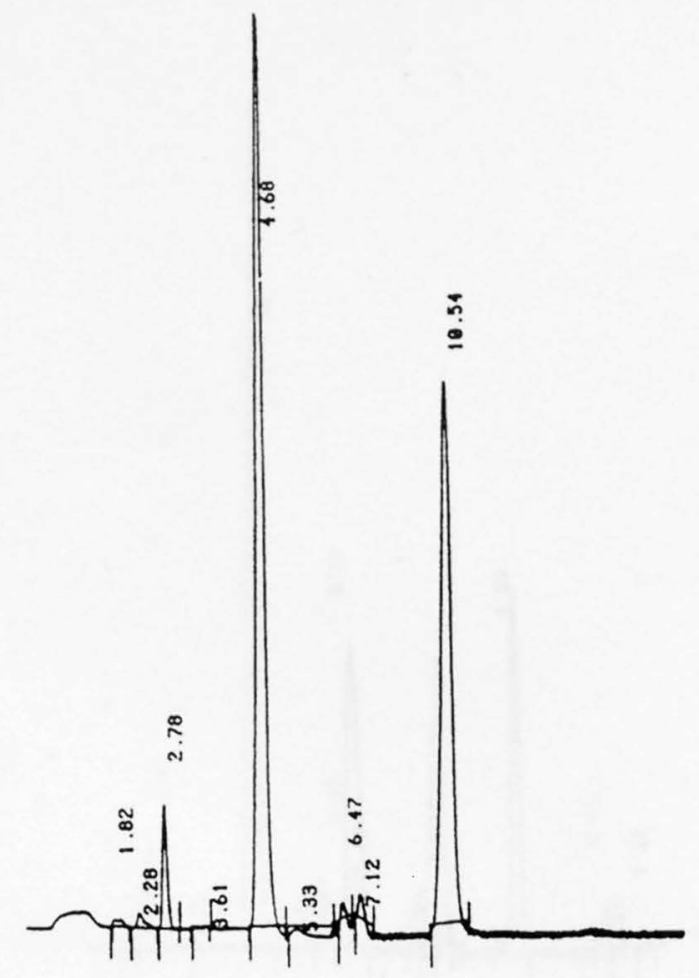

USGS 29, 7/19/96, ID39020.RAW, No. 82

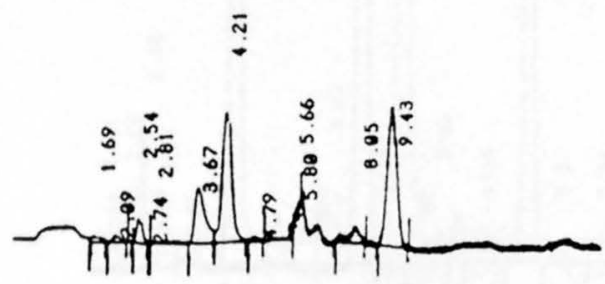

USGS 31, 10/11/94, ID51020.RAW, No. 83

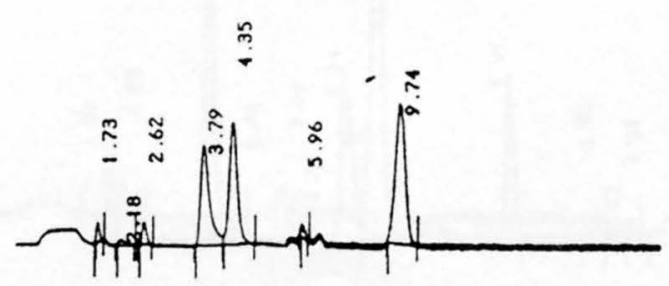

USGS 31, 6/15/95, ID45016.RAW, No. 84 


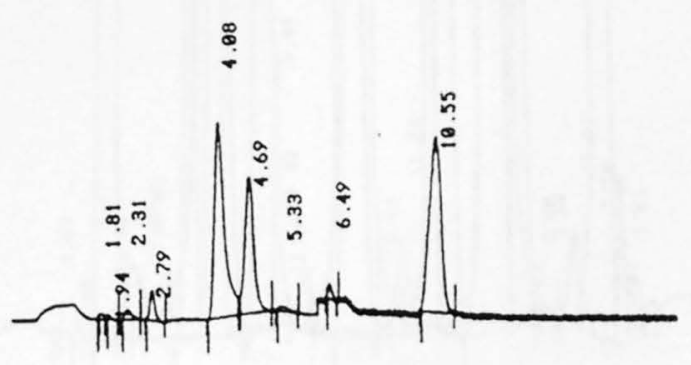

USGS 31, 7/19/96, ID41016.RAW, No. 85

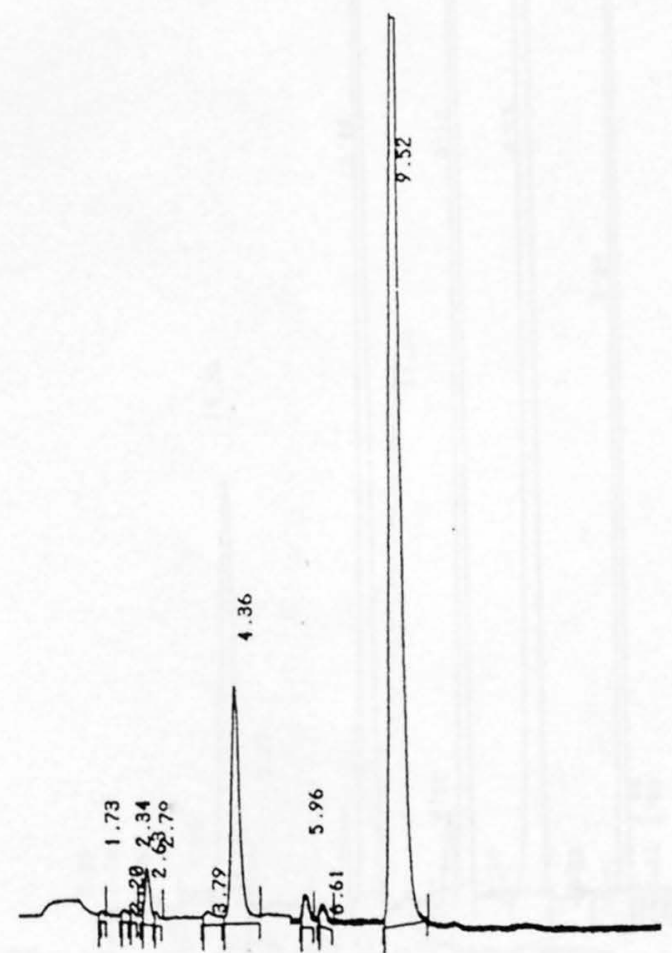

USGS 32, 6/15/95, ID45018.RAW, No. 87

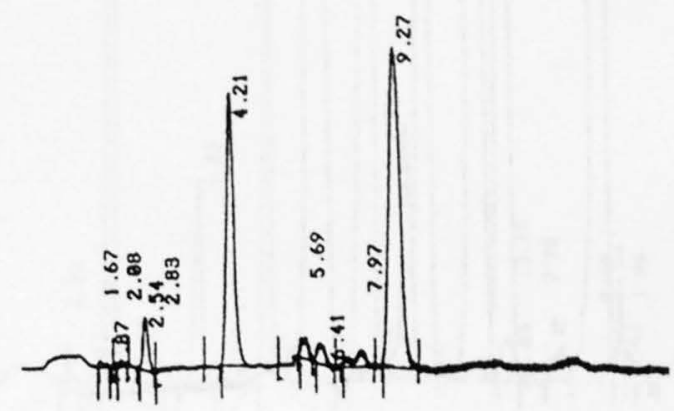

USGS 32, 10/11/94, ID51018.RAW, No. 86

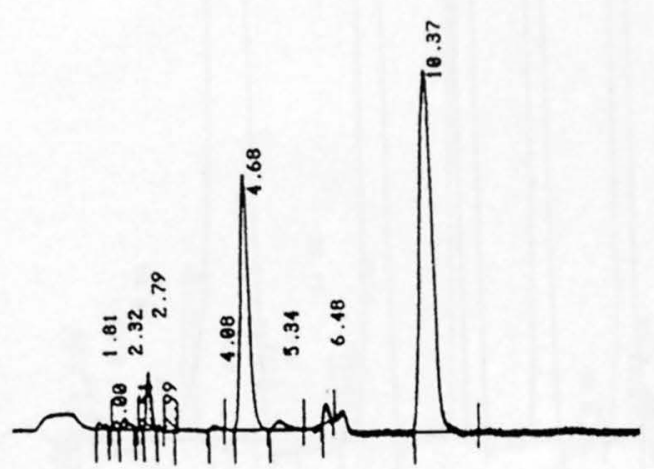

USGS 32, 7/19/96, ID41022.RAW, No. 88 


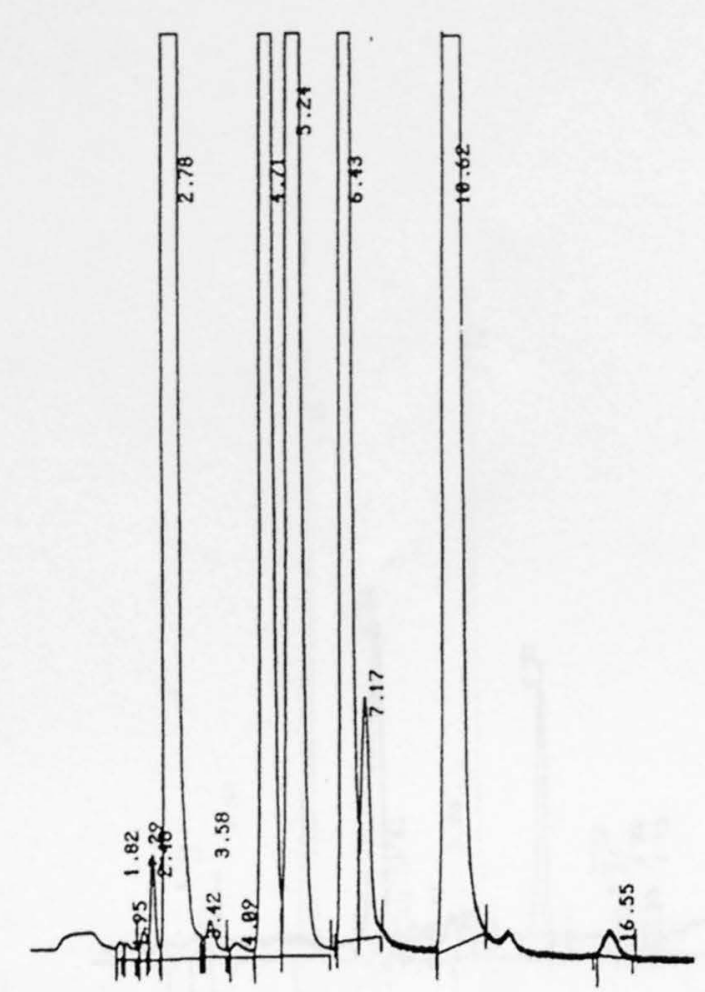

USGS 36, 7/16/96, ID40009.RAW, No. 89

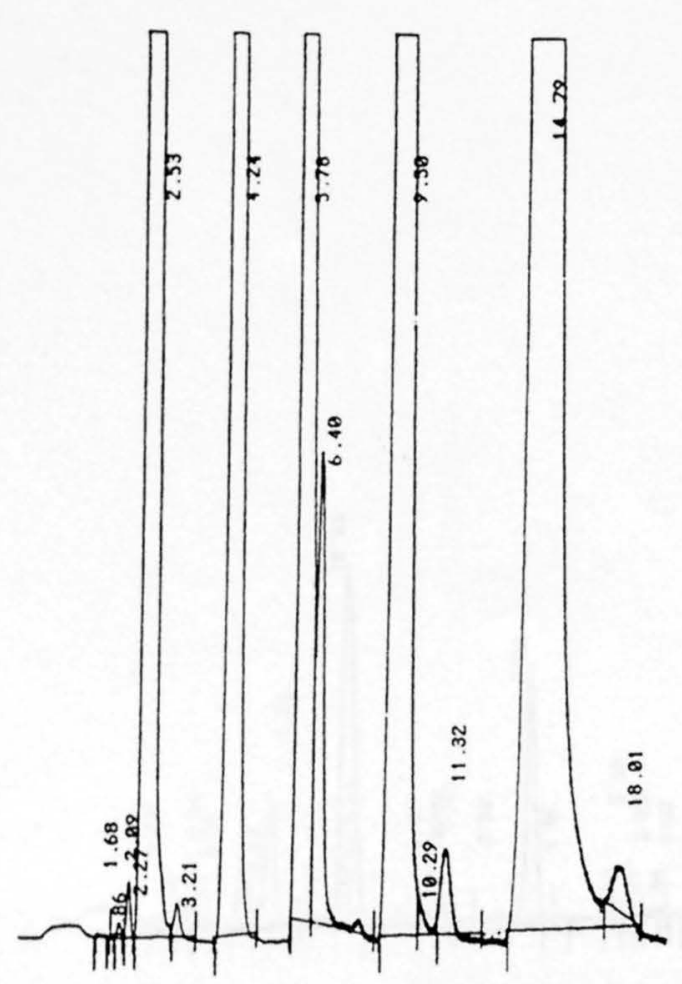

USGS 65, 10/12/94, ID52021.RAW, No. 91

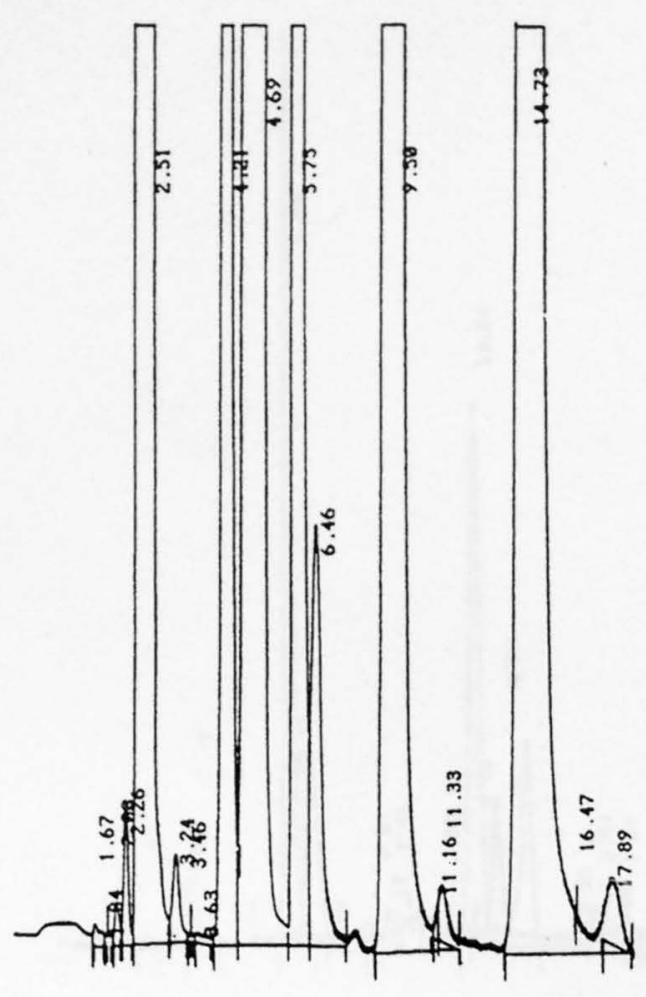

USGS 37, 10/7/94, ID53024.RAW, No. 90

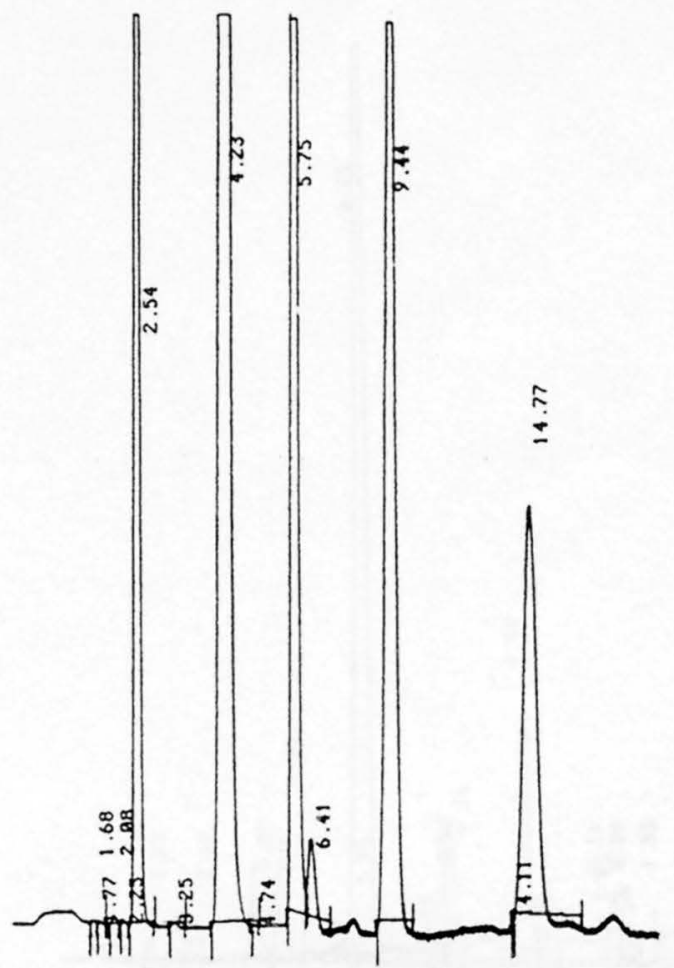

USGS 76, 10/12/94, ID52015.RAW, No. 92 


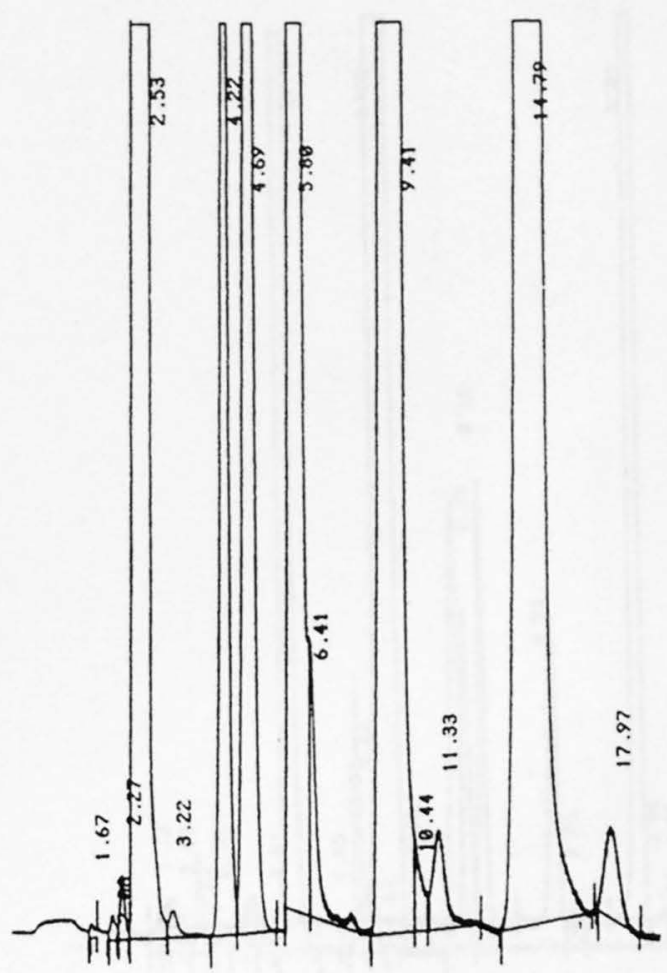

USGS 77, 10/7/94, ID52020.RAW, No. 93

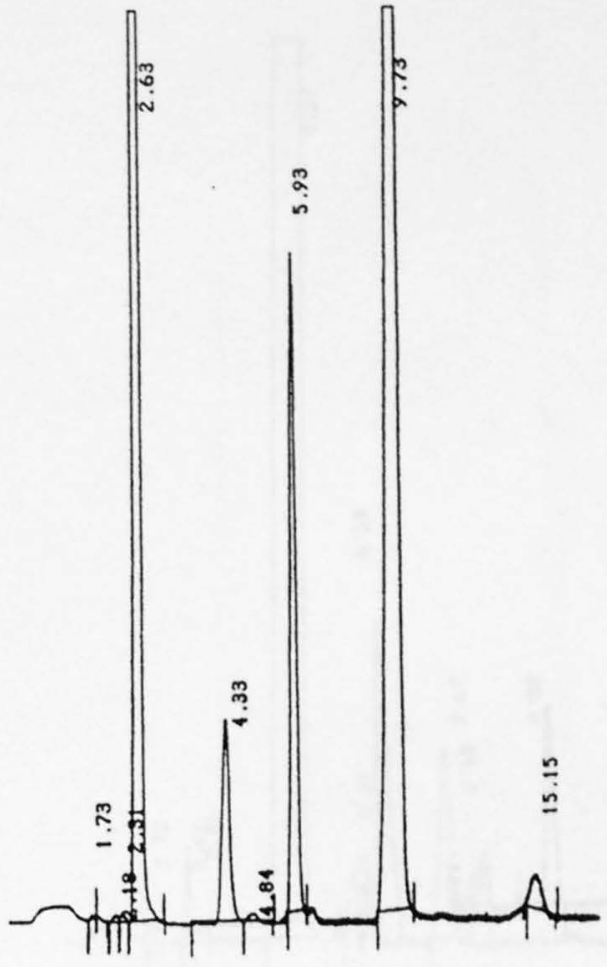

USGS 82, 7/16/96, ID48022.RAW, No. 94

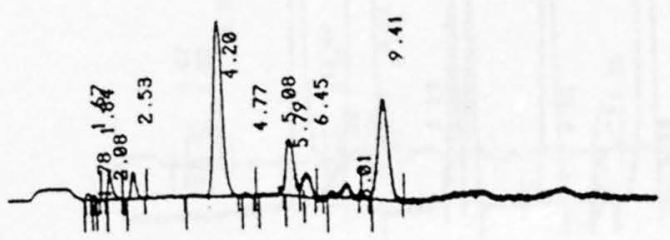

USGS 86, 10/4/94, ID52010.RAW, No. 96 


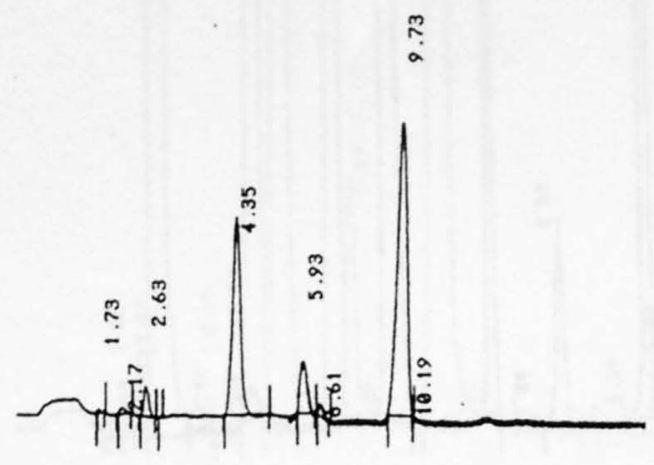

USGS 86, 10/11/96, ID48016.RAW, No. 97

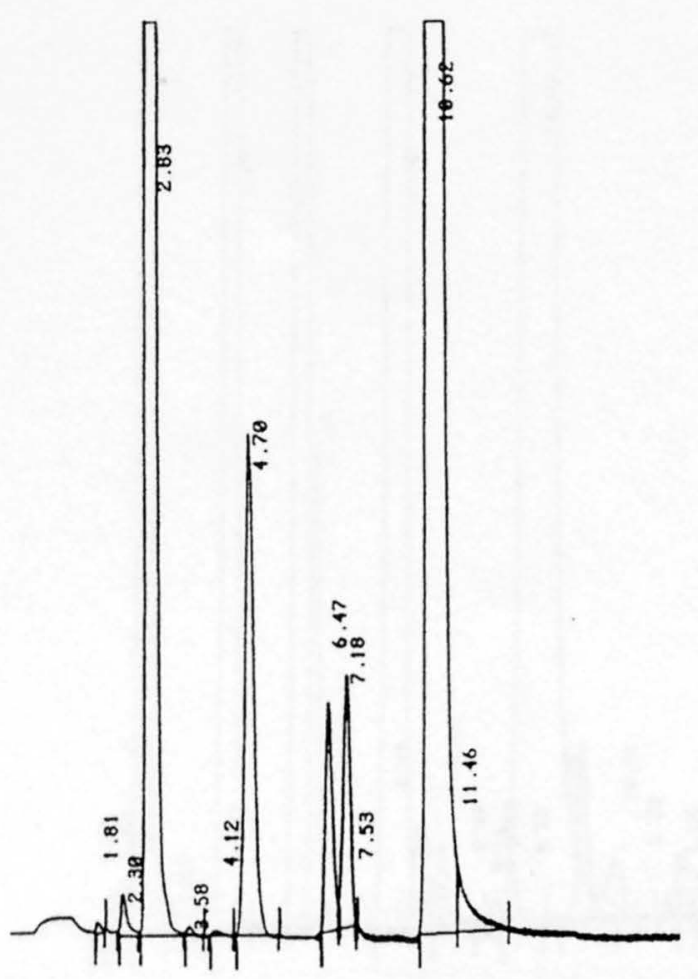

USGS 89, 7/17/96, ID37011.RAW, No. 99

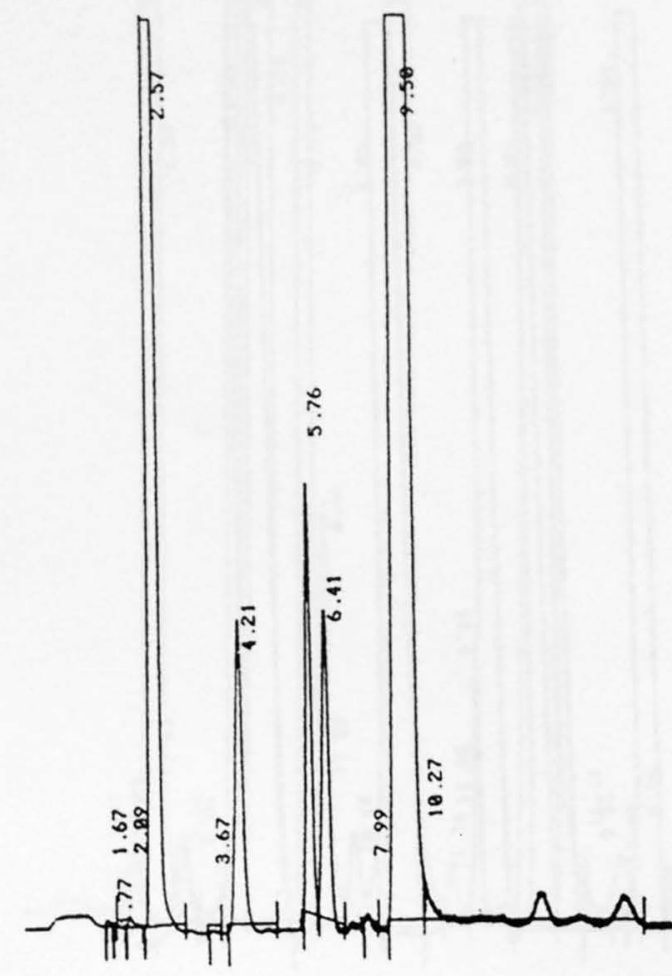

USGS 89, 10/7/94, ID52016.RAW, No. 98

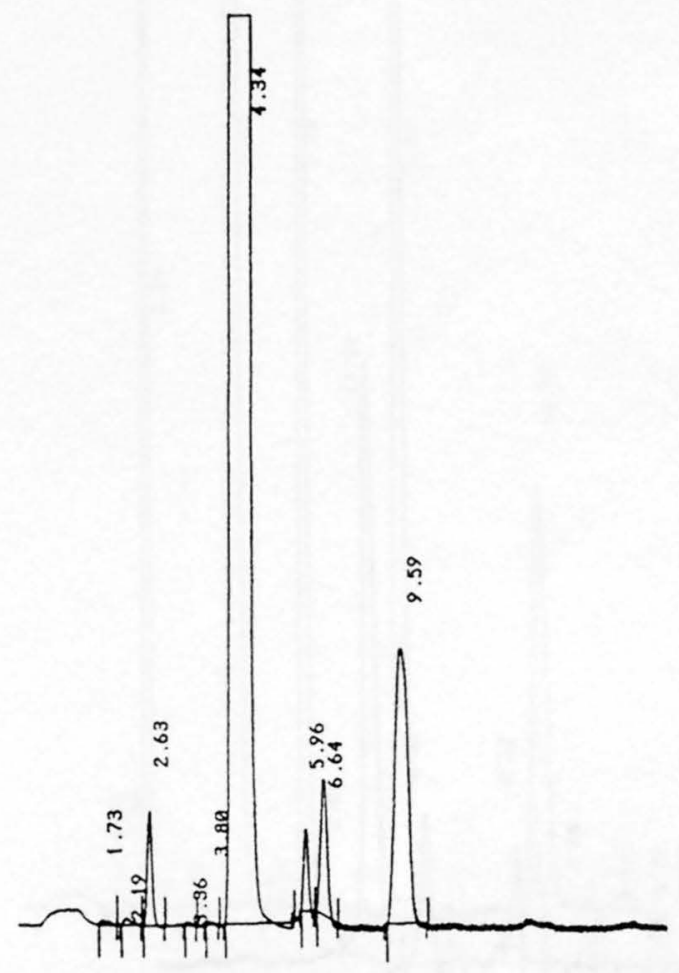

USGS 97, 6/13/95, ID45006.RAW, No. 100 


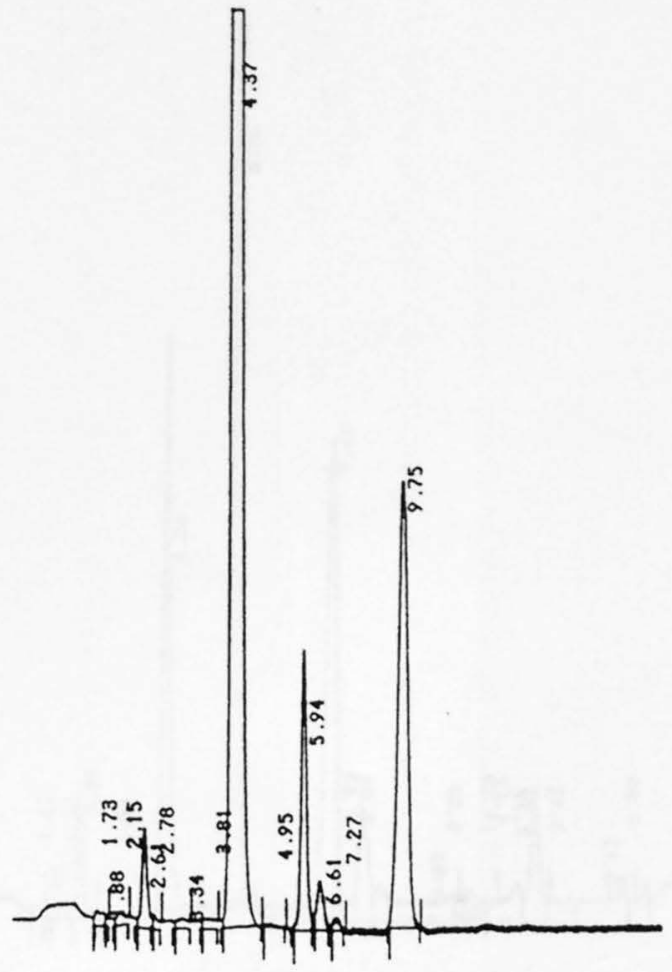

USGS 98, 6/12/95, ID44016.RAW, No. 101

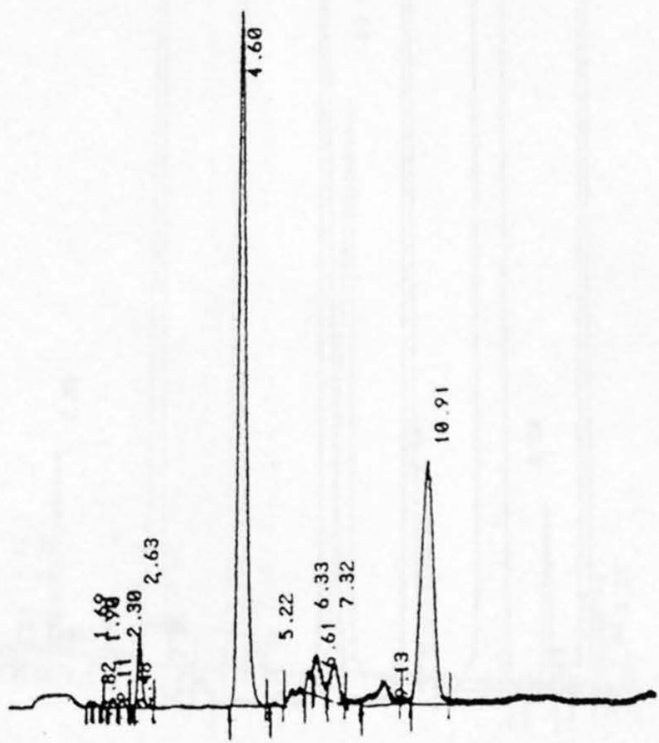

USGS 100, 4/21/95, SC03016.RAW, No. 103

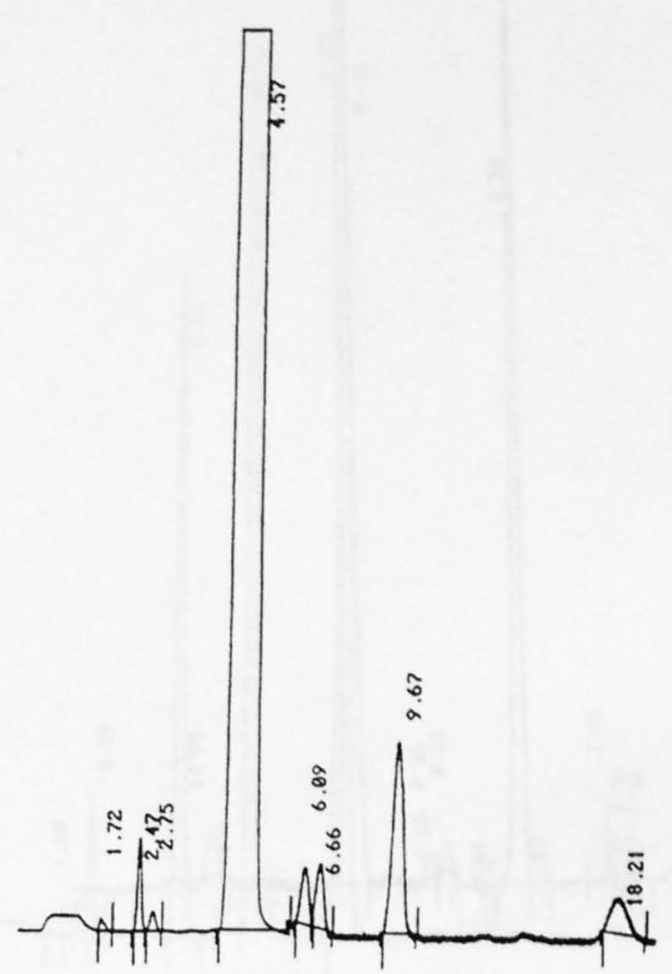

USGS 99, 6/12/95, ID44018.RAW, No. 102

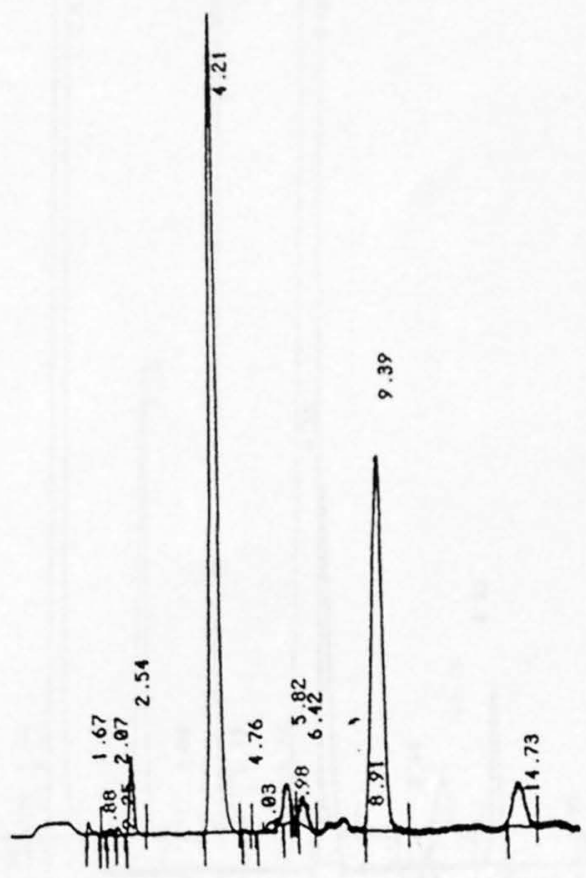

USGS 100, 10/10/96, ID49009.RAW, No. 104 


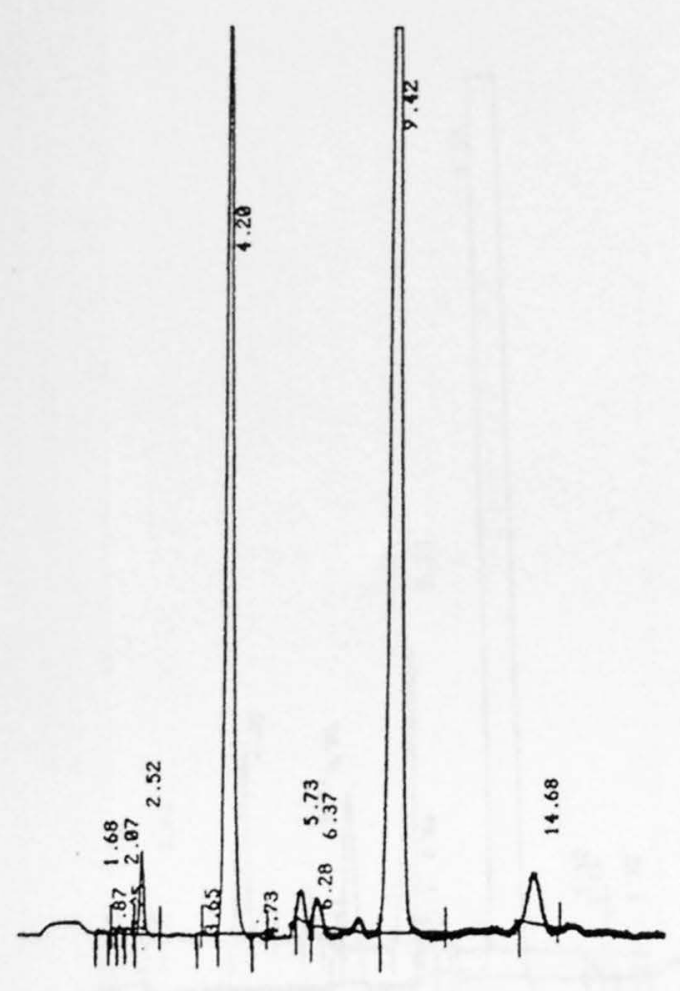

USGS 100, 10/10/96, ID53018.RAW, No. 105

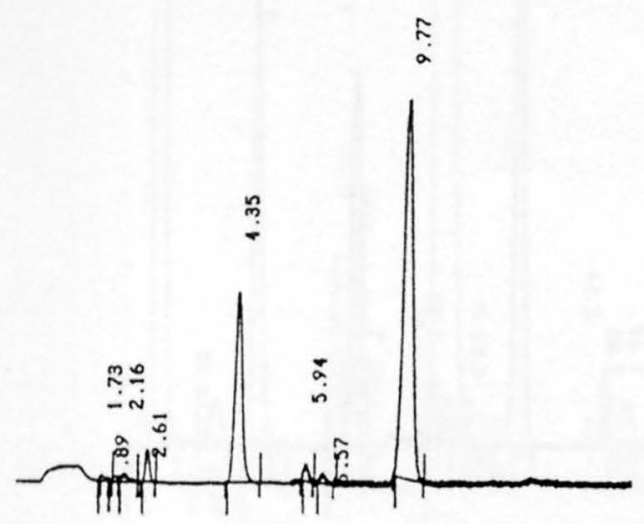

USGS 101, 10/10/96, ID46013.RAW, No. 107

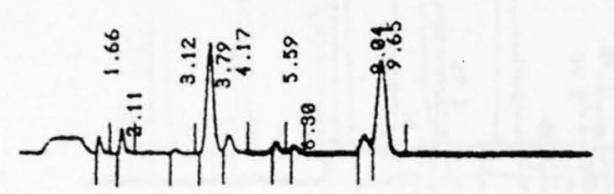

USGS 101, 4/21/95, ID22020.RAW, No. 106

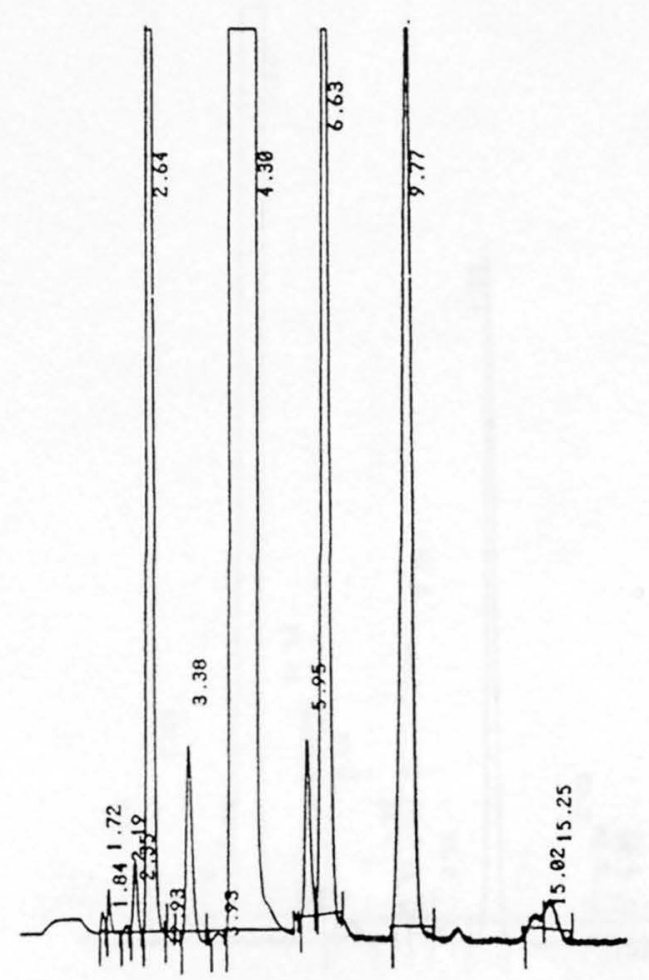

USGS 102, 6/13/95, ID45008.RAW, No. 108 


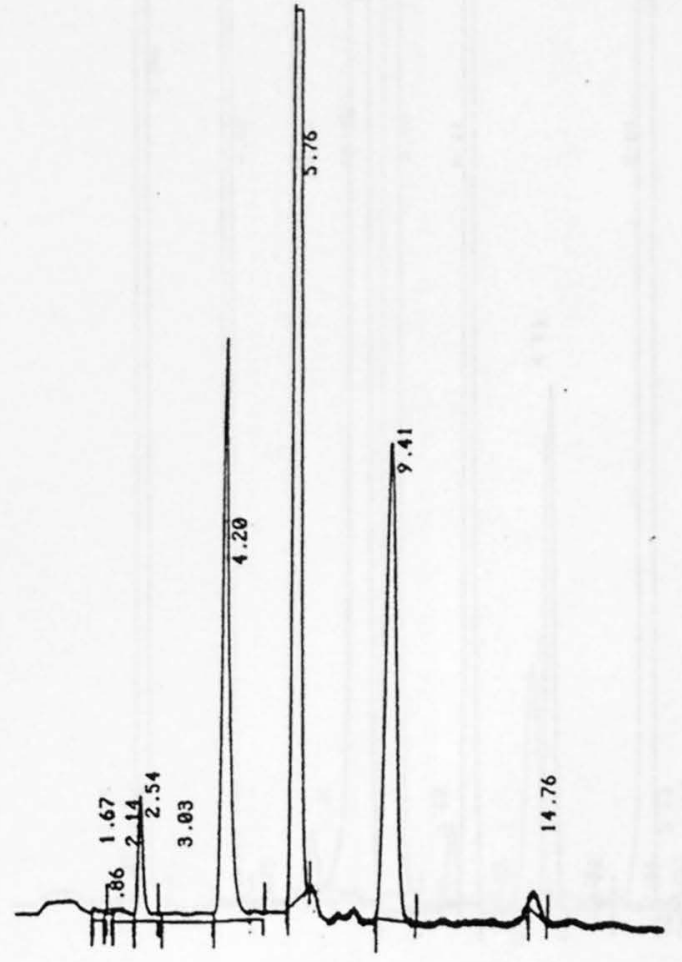

USGS 103, 7/20/94, ID49018.RAW, No. 109

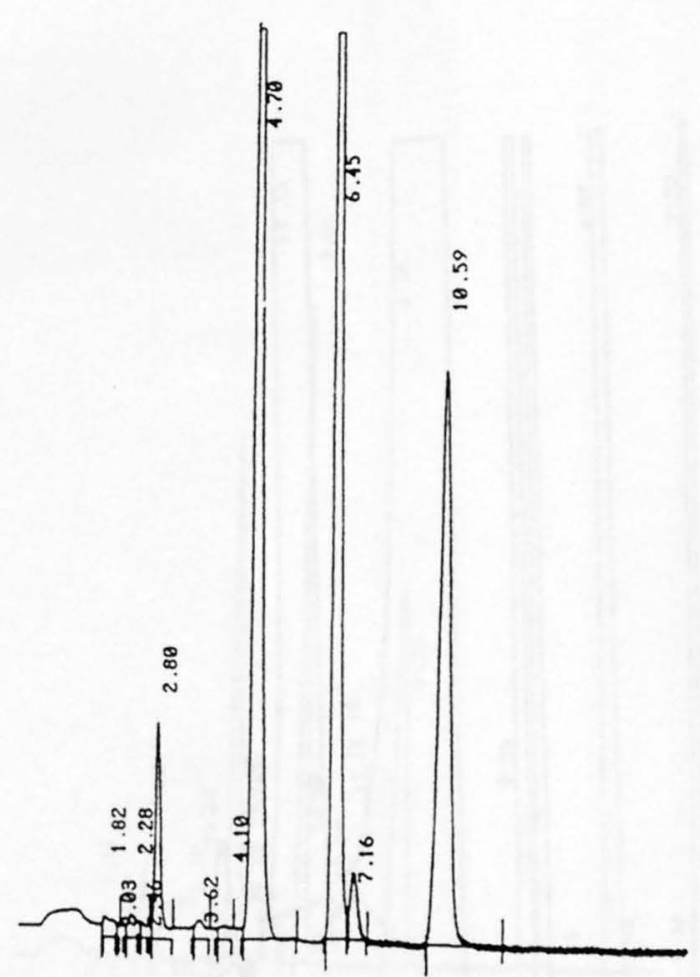

USGS 103, 7/15/96, ID41013.RAW, No. 111

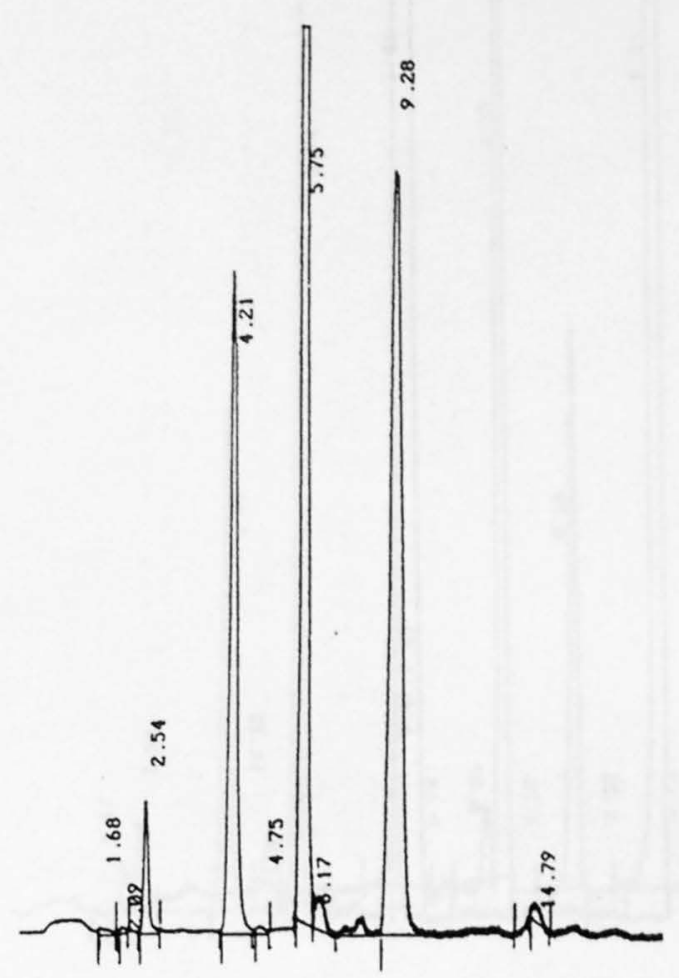

USGS 103, 4/18/95, ID53014.RAW, No. 110

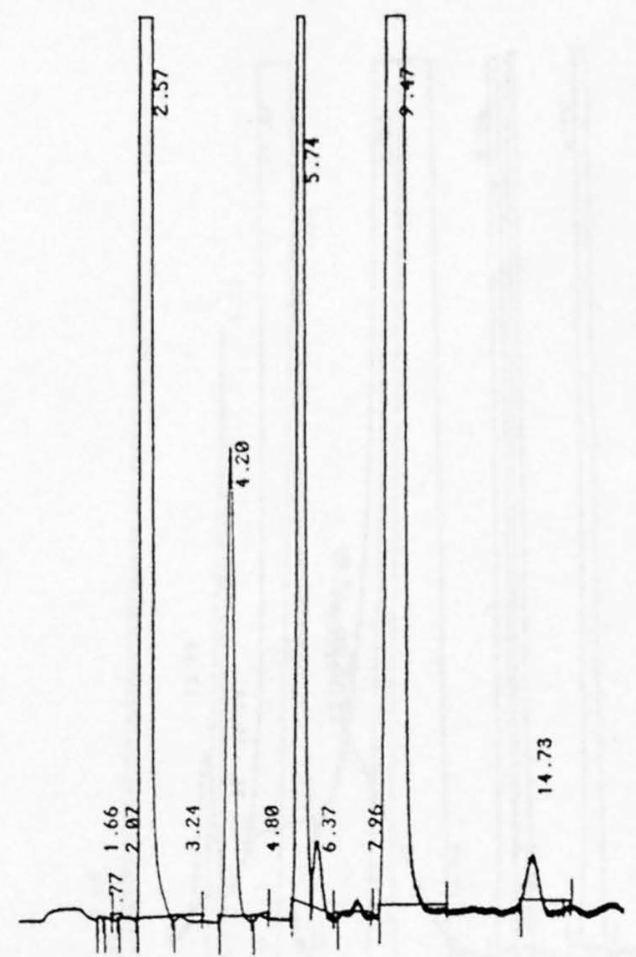

USGS 104, 7/20/94, ID49019.RAW, No. 112 


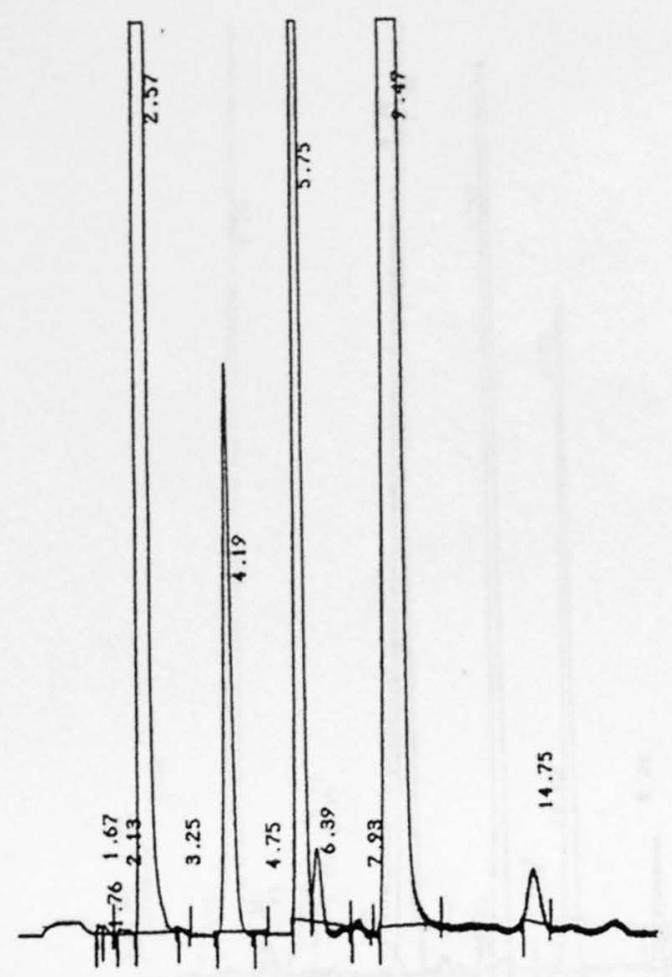

USGS 104, 4/18/95, ID53015.RAW, No. 113

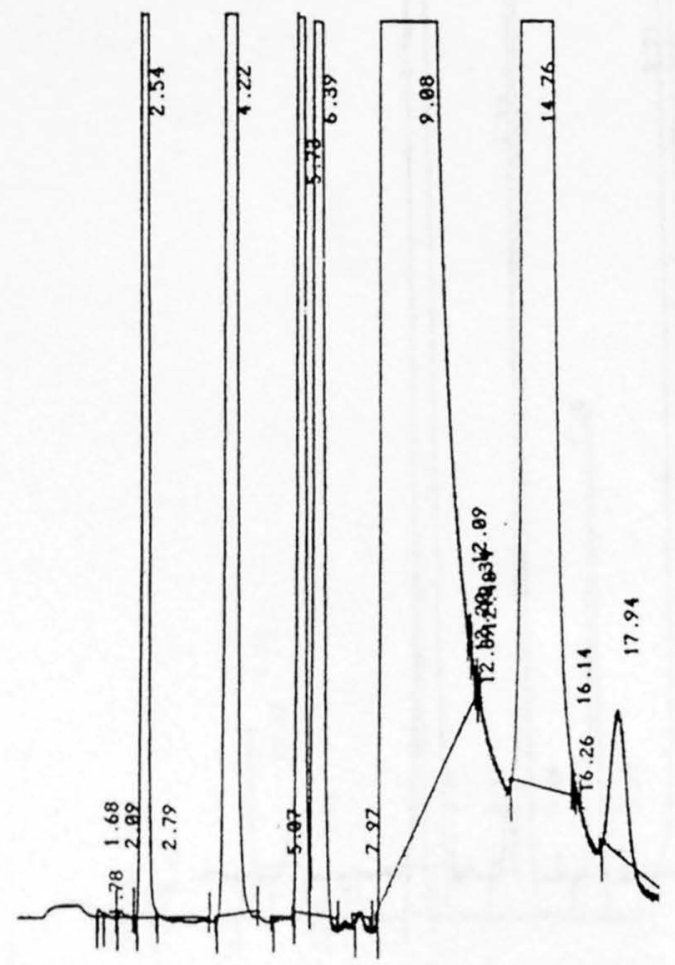

USGS 105, 10/3/94, ID53025.RAW, No. 115

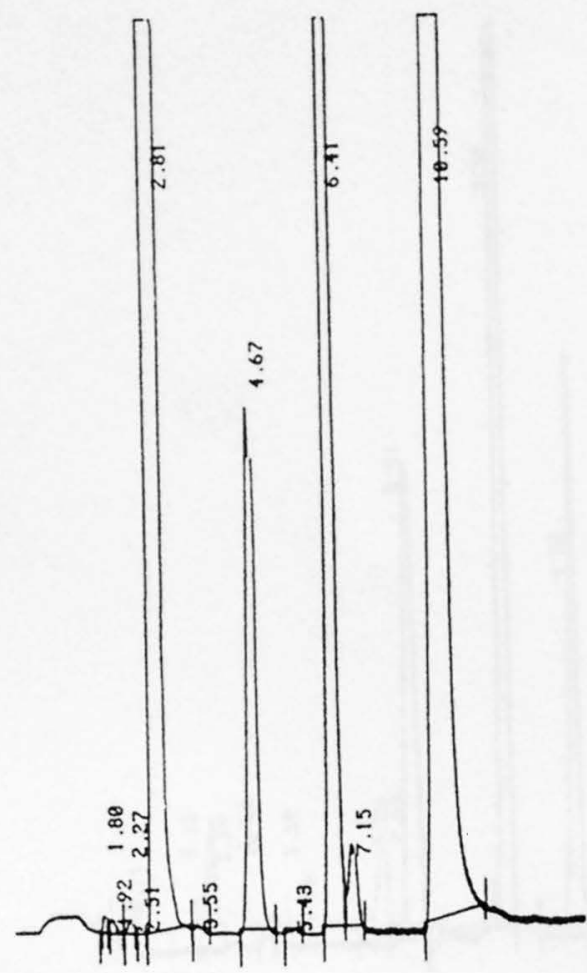

USGS 104, 7/15/96, ID39022.RAW, No. 114

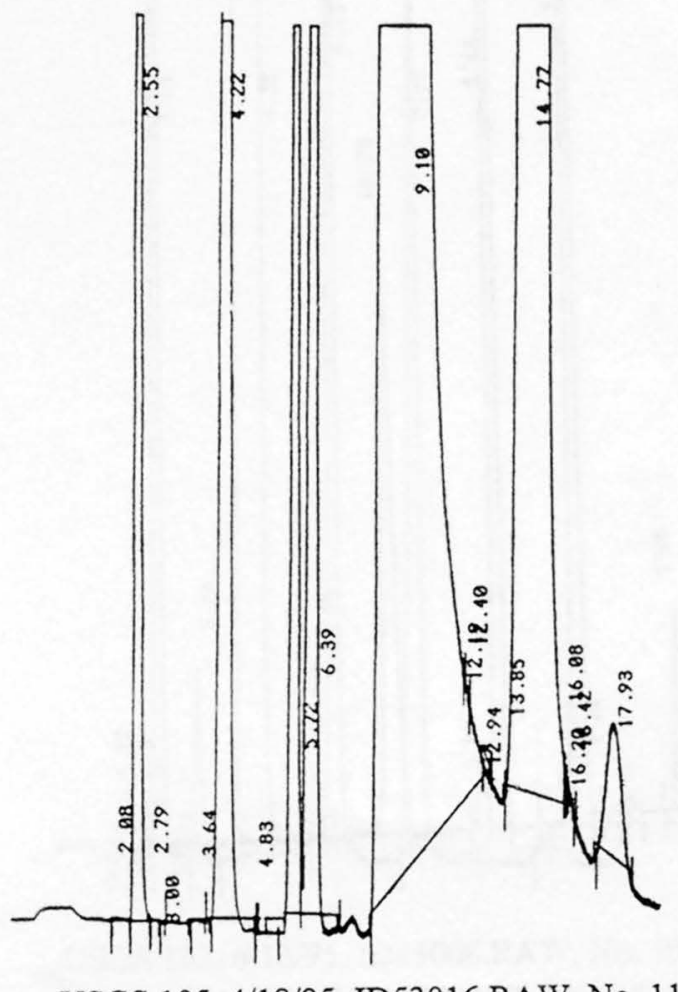

USGS 105, 4/18/95, ID53016.RAW, No. 116 


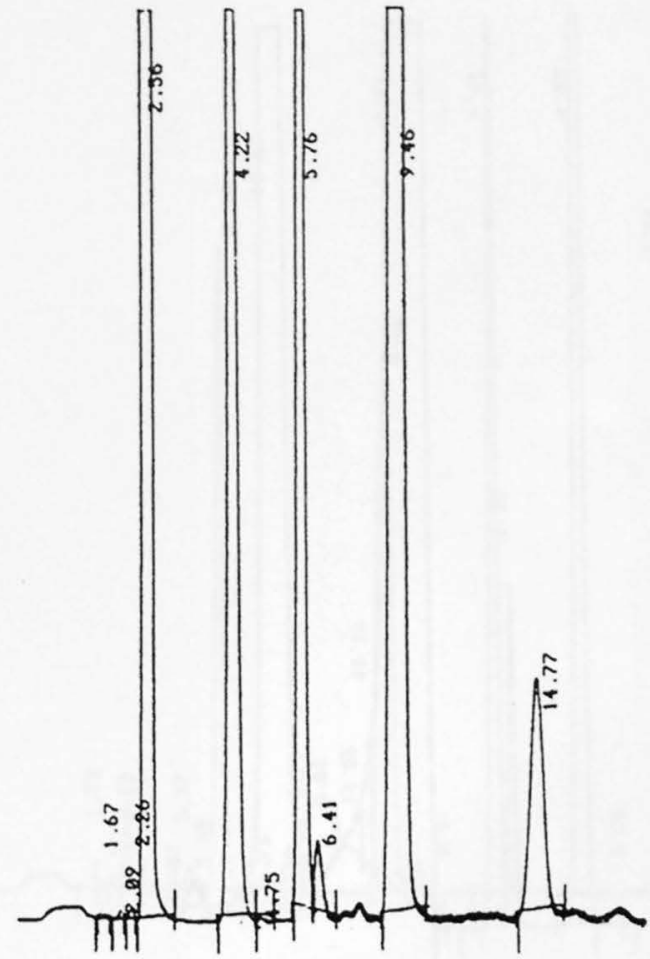

USGS 106, 10/5/94, ID52017.RAW, No. 117

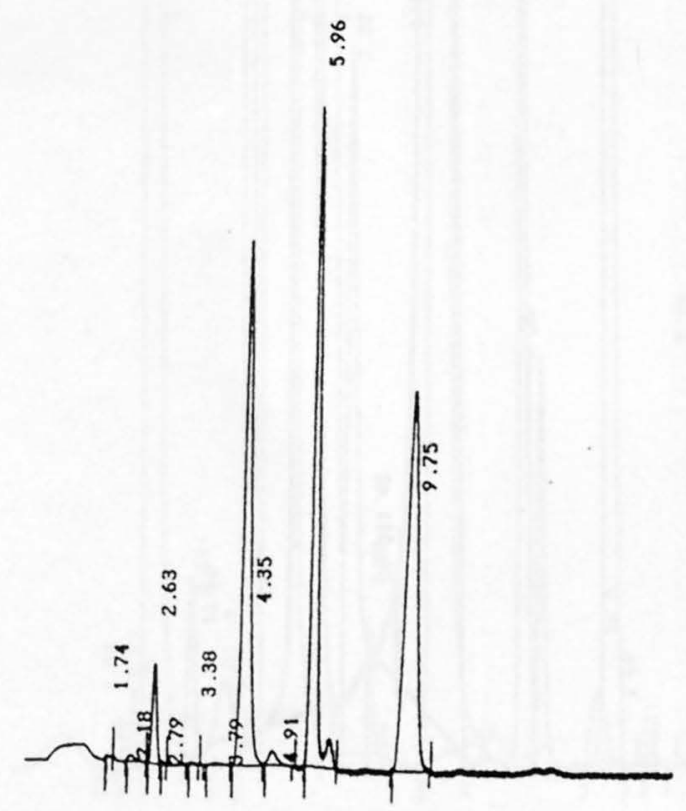

USGS 107, 10/9/96, ID47017.RAW, No. 119

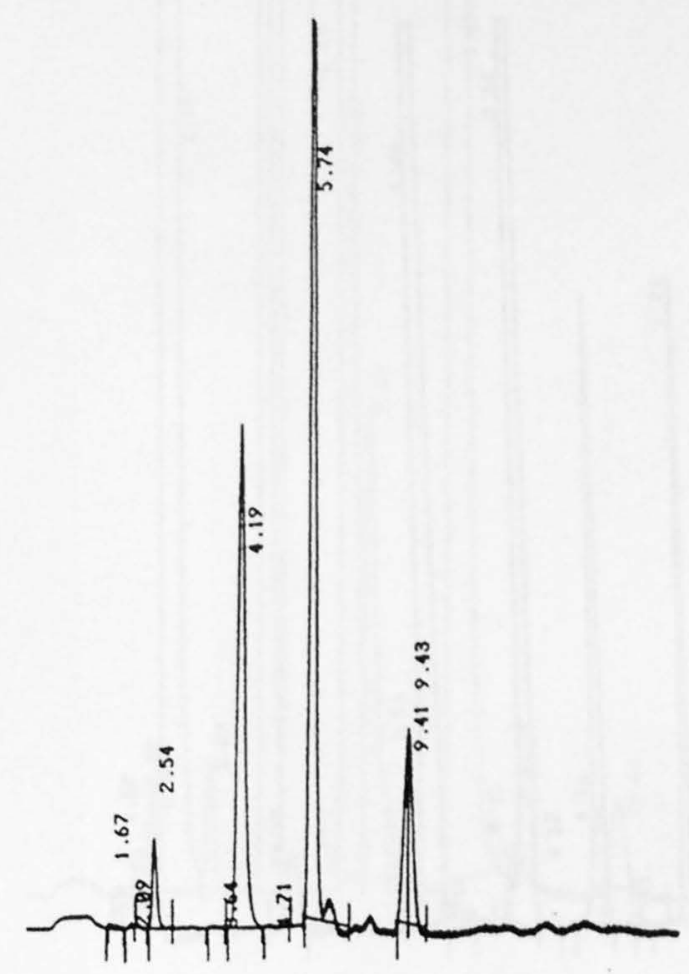

USGS 107, 10/5/95, ID52014.RAW, No. 118

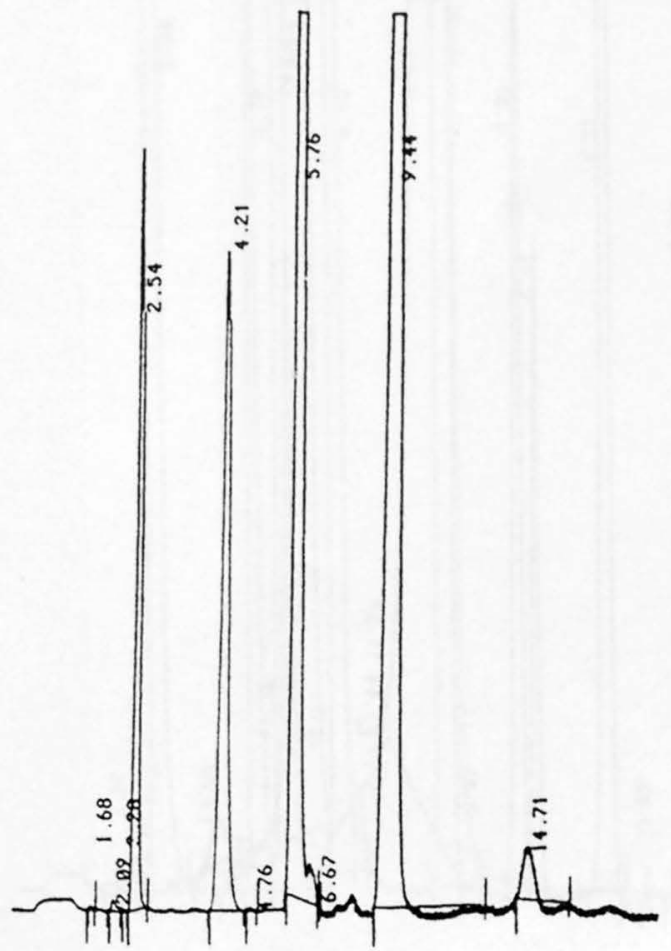

USGS 108, 10/3/94, ID53021.RAW, No. 120 


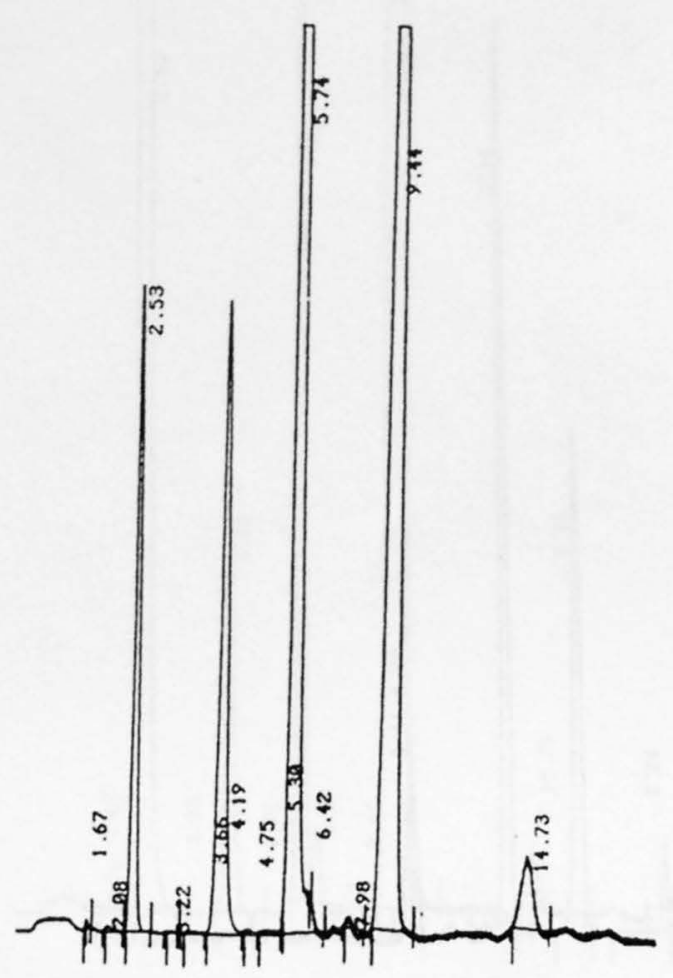

USGS 108, 4/18/95, ID53020.RAW, No. 121

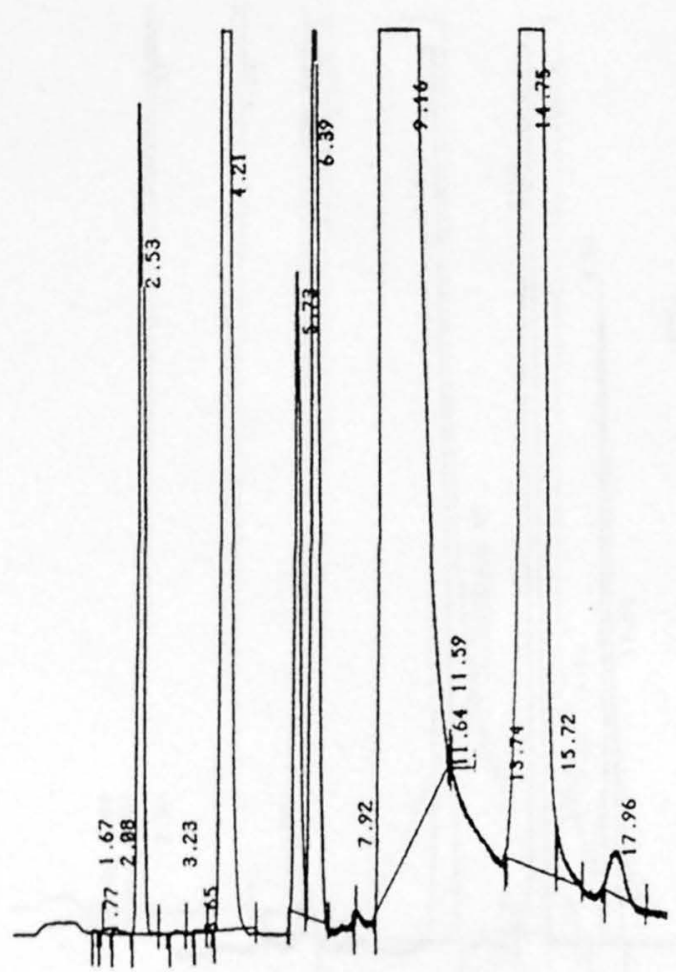

USGS 109, 4/20/95, ID53017.RAW, No. 123

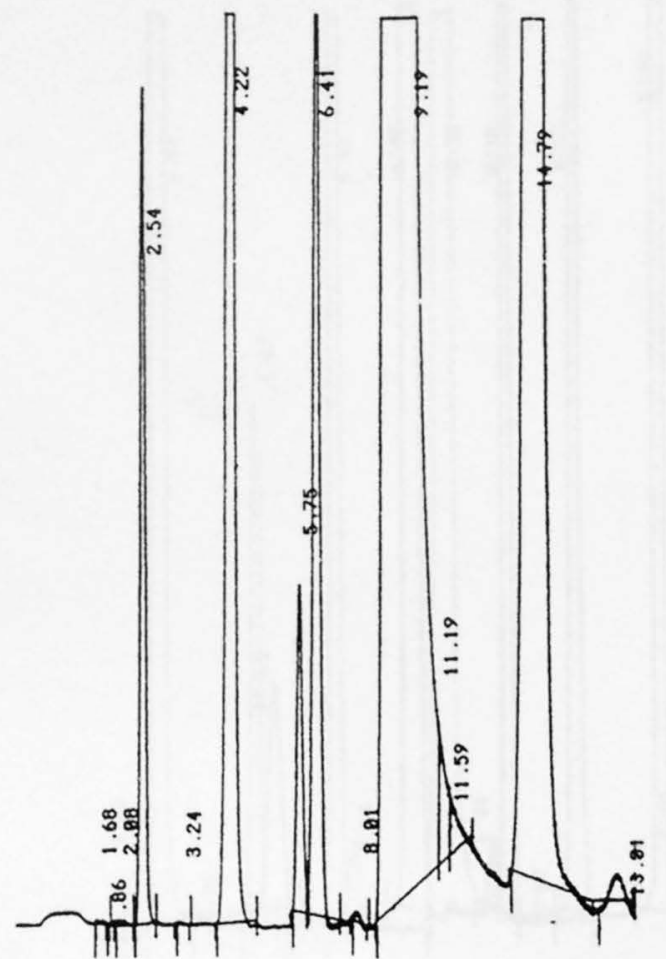

USGS 109, 10/4/94, ID52019.RAW, No. 122

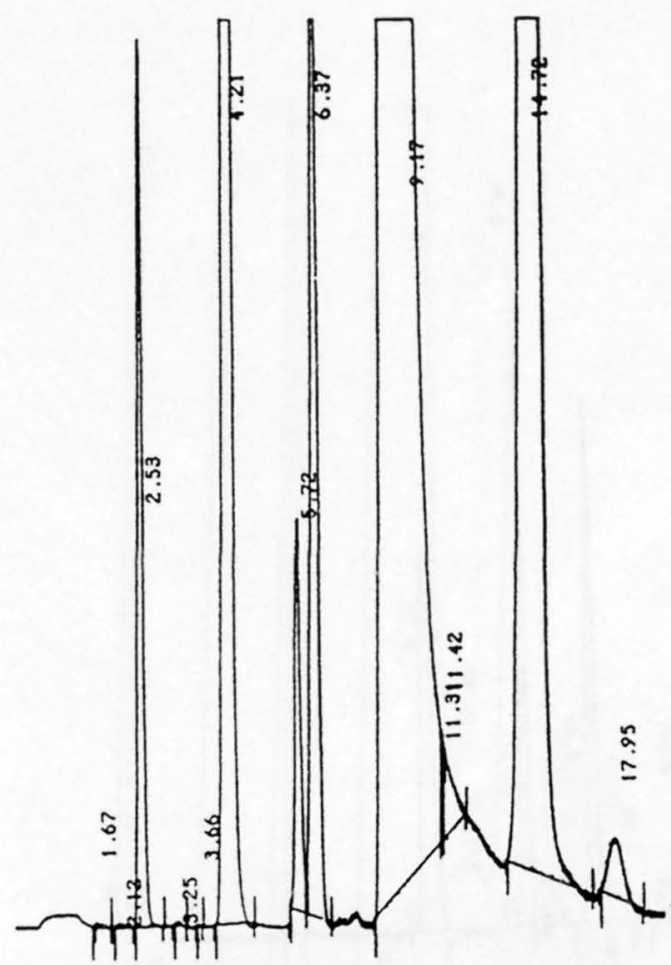

USGS 109, 10/11/96, ID49017.RAW, No. 124 


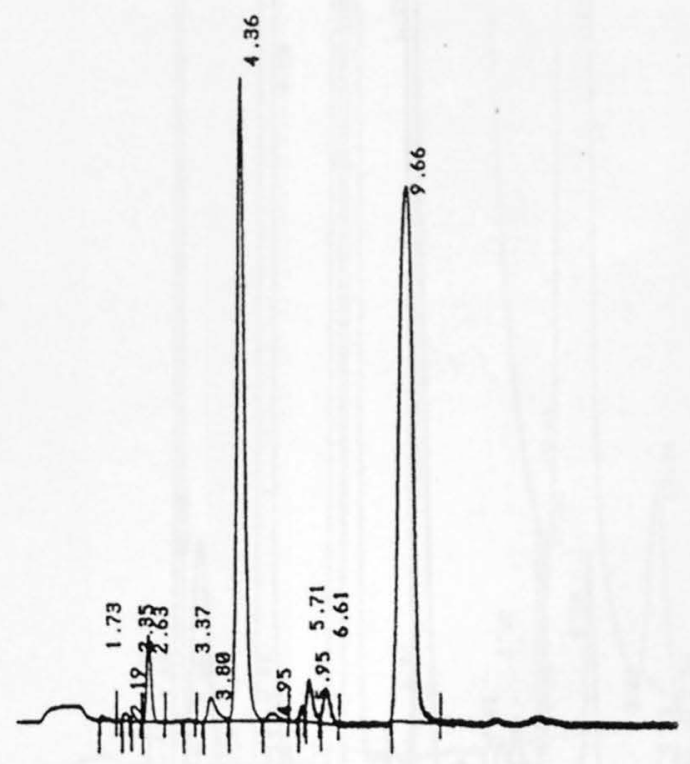

USGS 110A, 10/9/96, ID47013.RAW, No. 125

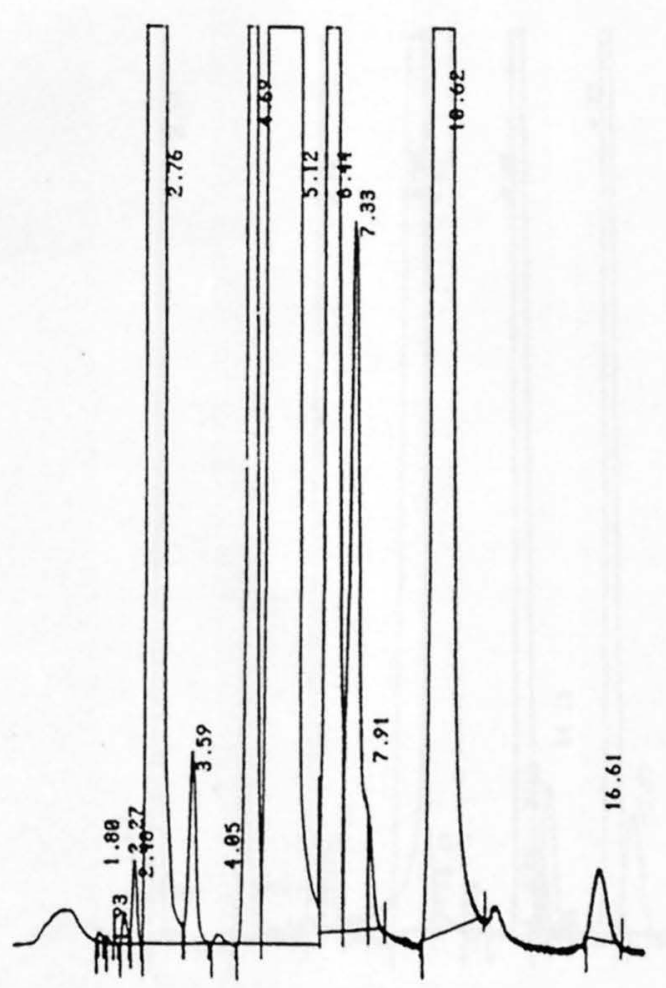

USGS 113, 7/16/96, ID39024.RAW, No. 127

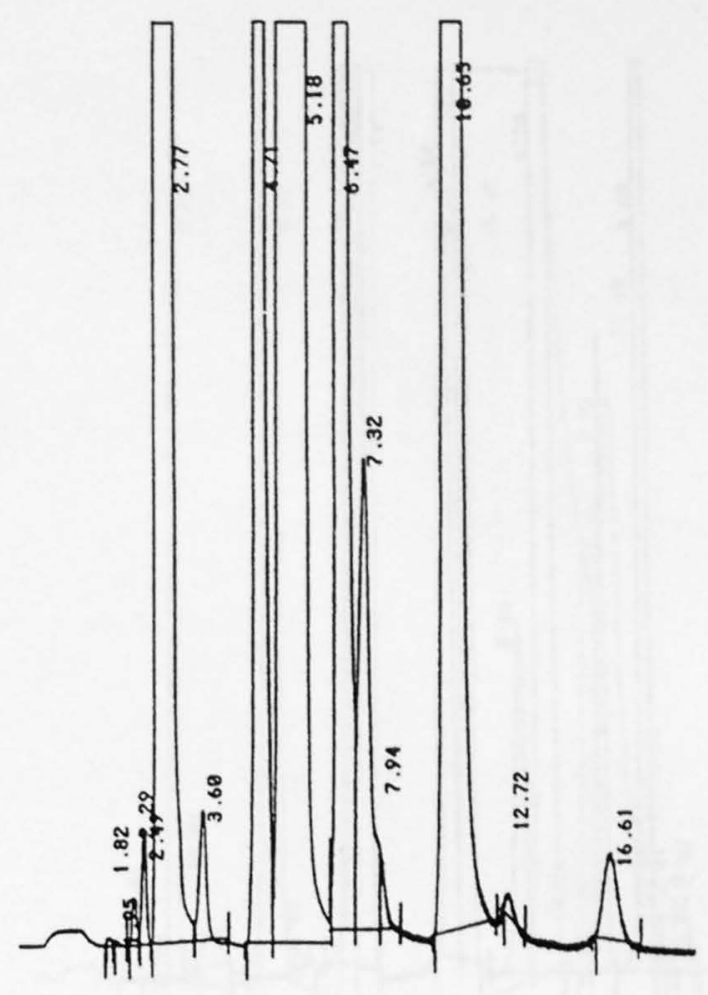

USGS 112, 7/15/96, ID41011.RAW, No. 126

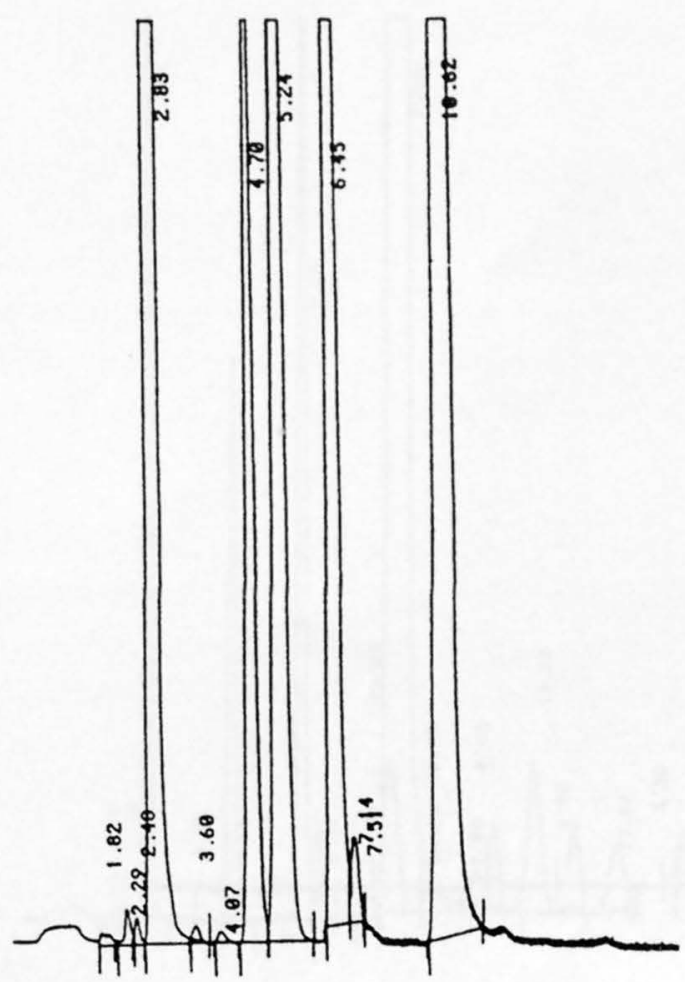

USGS 115, 7/15/96, ID41009.RAW, No. 128 


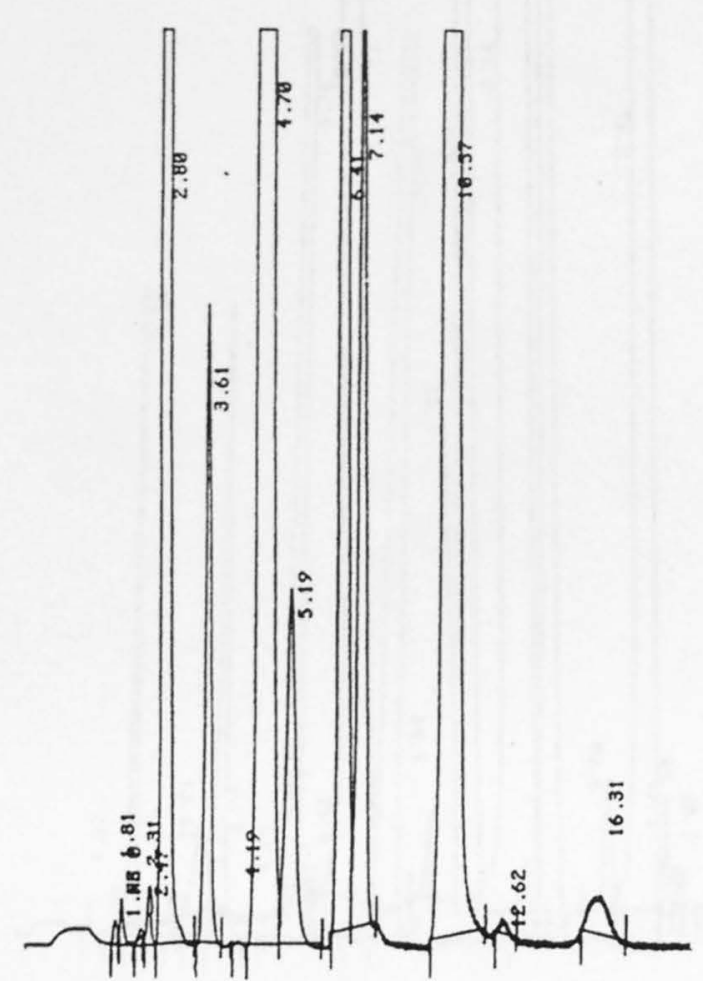

USGS 116, 7/15/96, ID40021.RAW, No. 129

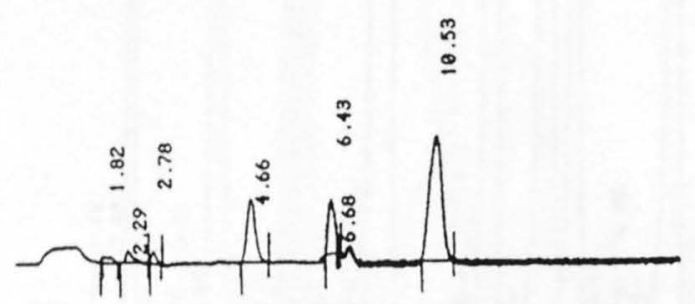

USGS 117, 7/17/96, ID39013.RAW, No. 131

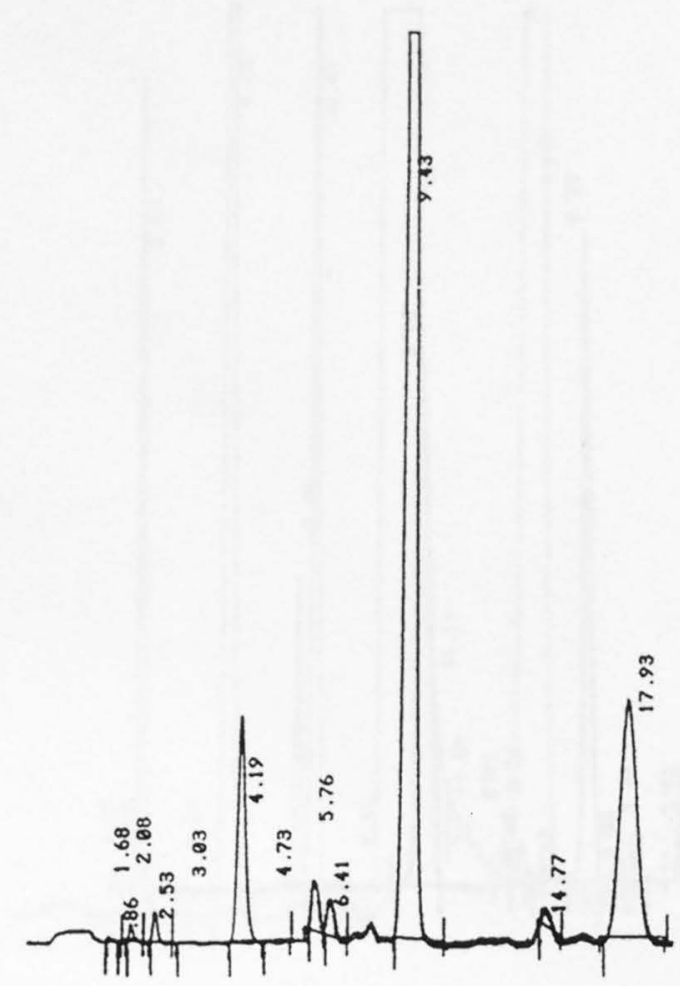

USGS 117, 10/5/94, ID52013.RAW, No. 130

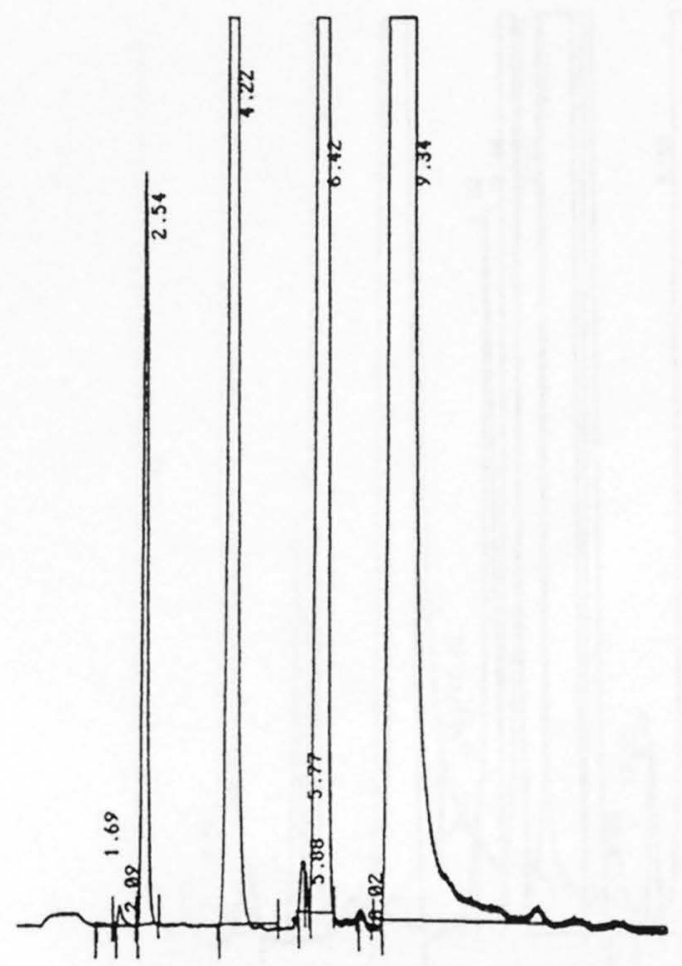

USGS 119, 10/6/94, ID52018.RAW, No. 132 


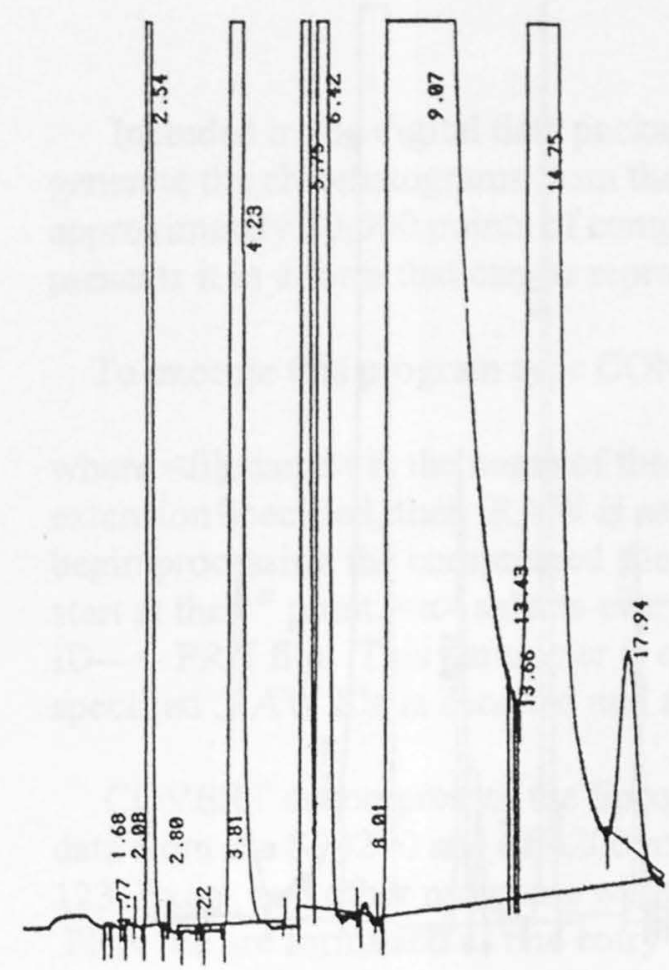

USGS 120, 10/6/94, ID53023.RAW, No.133

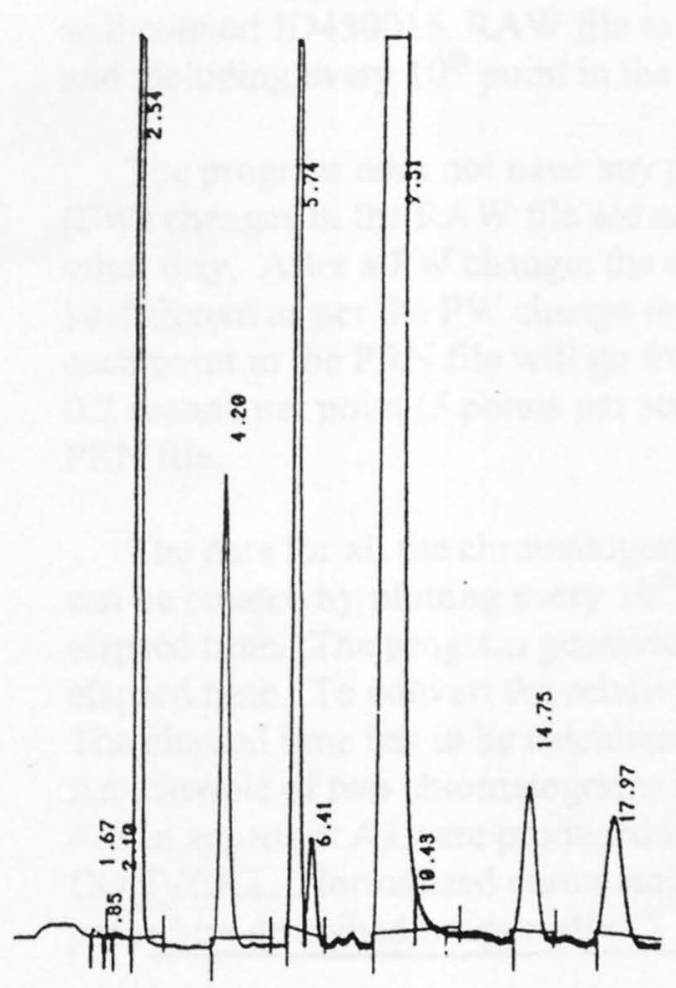

USGS 124, 7/20/94, ID49020.RAW, No. 135

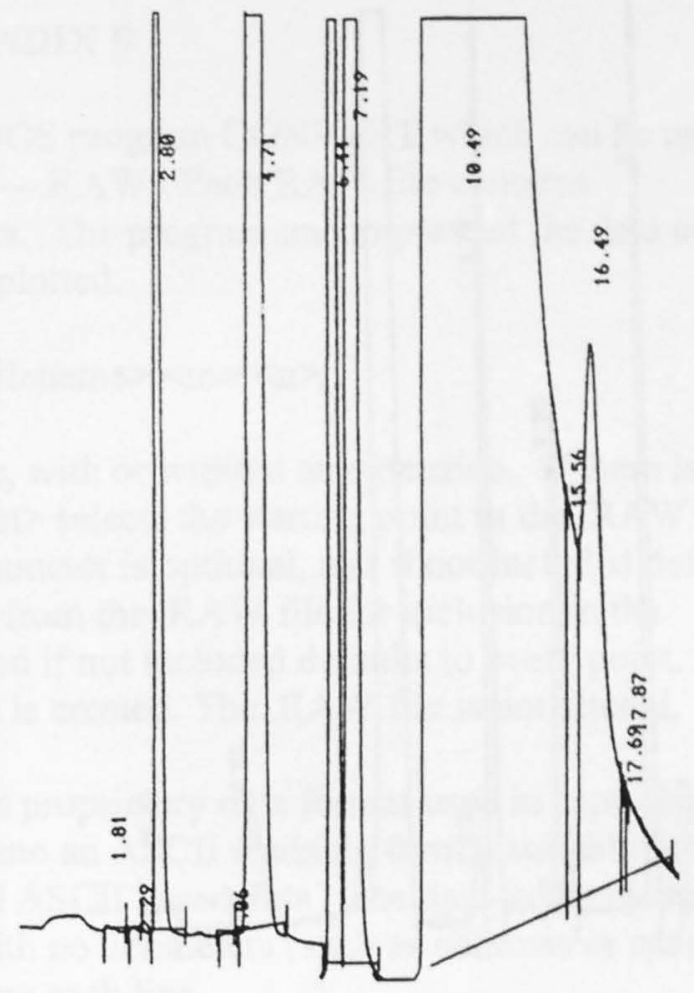

USGS 120, 7/17/96, ID37013.RAW, No. 134

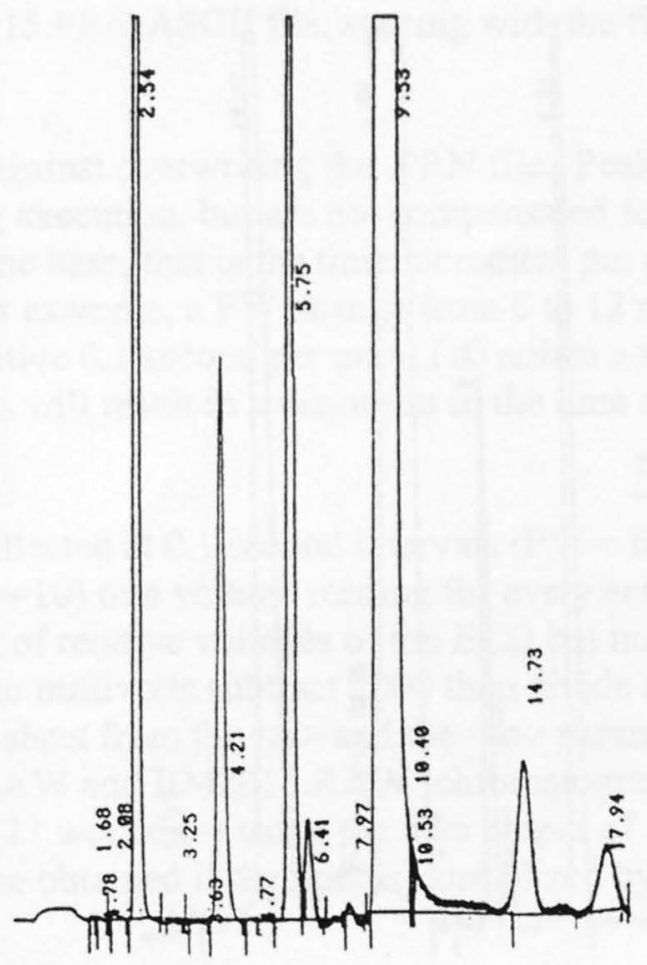

USGS 124, 4/20/95, ID53022.RAW, No. 136 


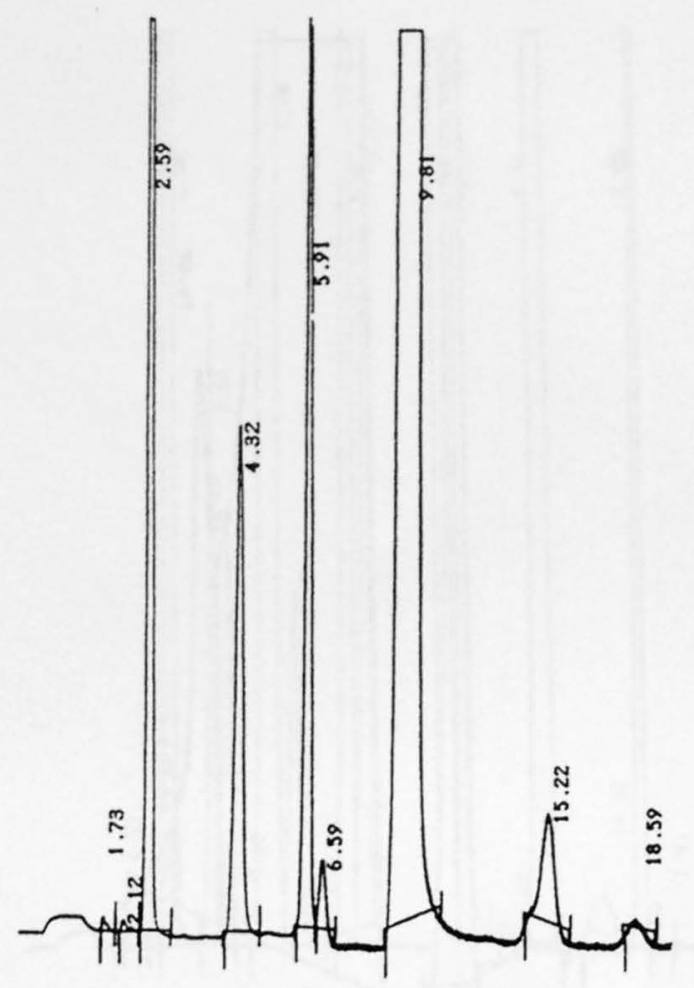

USGS 124, 10/9/96, ID46020.RAW, No.137

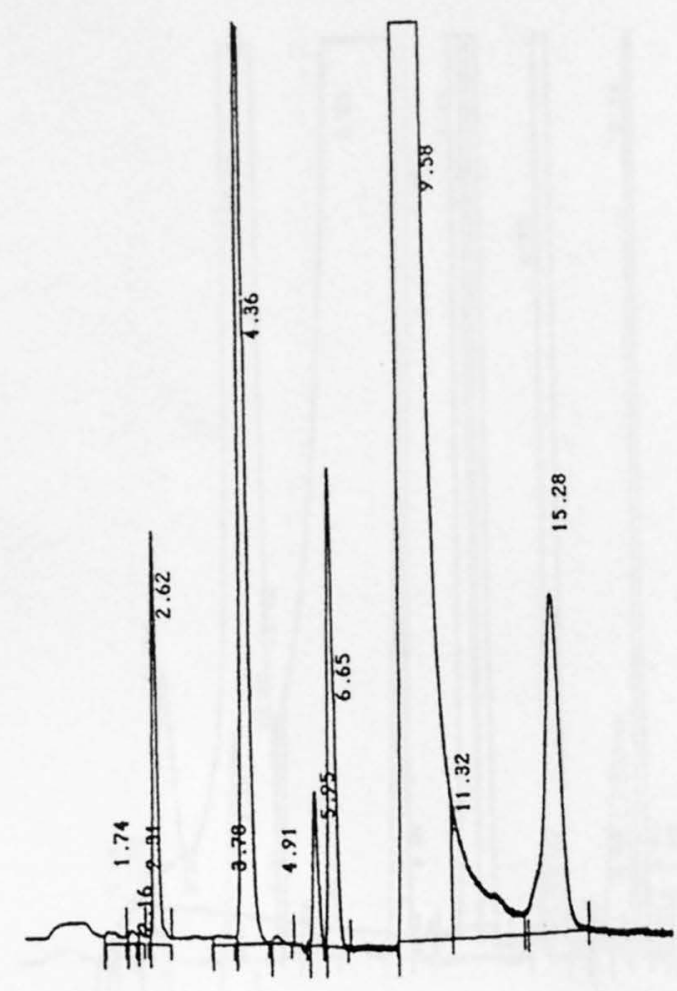

USGS 125, 6/6/95, ID46015.RAW, No. 138

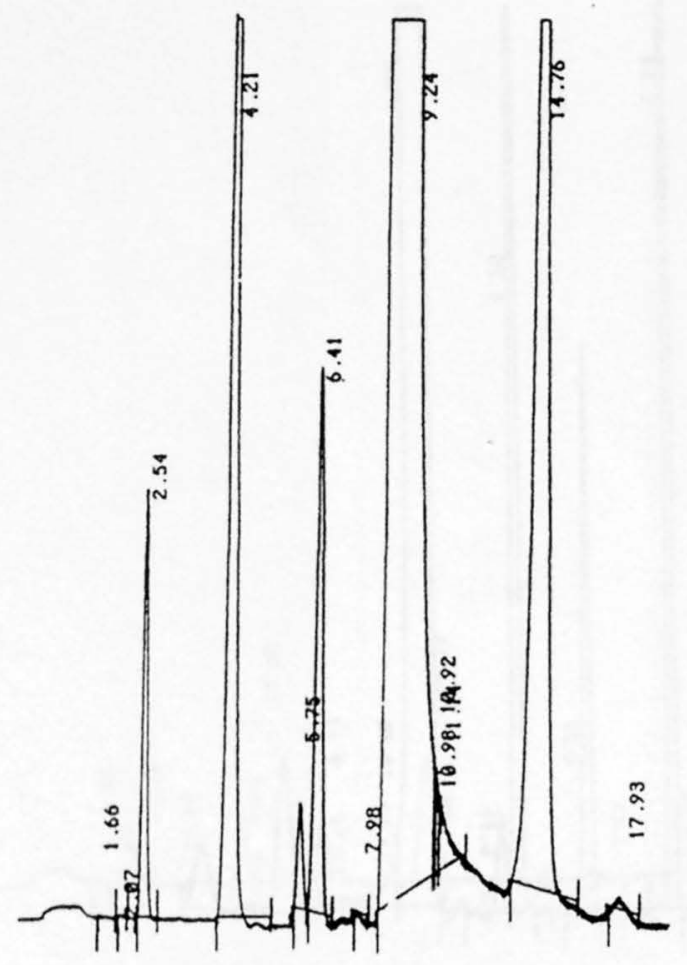

USGS 125, 10/11/96, ID50012.RAW, No. 139
Blank, 6/6/95, ID45004.RAW, No. 140 


\section{APPENDIX B}

Included in the digital data package is the DOS program CONVERT which can be used to generate the chromatograms from the files ID----RAW. Each RAW file contains approximately 20,000 points of compressed data. The program uncompressed the data and presents it in a form that can be reprocessed or plotted.

To execute this program type CONVERT $<$ filename $><$ m $><$ n $>$,

where $<$ filename $>$ is the name of the .RAW file, with or without an extension. If there is no extension specified, then .RAW is assumed. $<\mathrm{m}>$ selects the starting point in the .RAW file to begin processing the compressed file. This parameter is optional, and if not included defaults to start at the $1^{\text {st }}$ point. $<\mathrm{n}>$ selects every $\mathrm{n}^{\text {th }}$ point from the. RAW file for inclusion in the ID----.PRN file. This parameter is optional, and if not included defaults to every point. The specified .RAW file is decoded and a .PRN file is created. The .RAW file is not altered.

COVERT decompresses the Spectra-Physics proprietary data format used in capturing raw data from the SP4270 and SP4200 integrators into an ASCII readable format suitable for Lotus 123, Excel, and other programs which will read ASCII based data. The data in the created .PRN file are formatted as one entry per line with no delimeters (such as commas or spaces) other than the carriage return/line feed separating each line.

For example:

\section{CONVERT ID450015.RAW 110}

will convert ID450015. RAW file to an ID450015.PRN ASCII file, starting with the first point and including every $10^{\text {th }}$ point in the PRN file.

The program does not have any protection against overwriting the .PRN file. Peak width (PW) changes in the RAW file are noted during execution, but are not compensated for in any other way. After a PW change, the effective time base, that is the time increment per point, will be different as per the PW change multiple. For example, a PW change from 6 to 12 means that each point in the PRN file will go from an effective 0.1 second per point ( 10 points a second) to 0.2 second per point ( 5 points per second). This will result in a distortion in the time axis of the PRN file.

The data for all the chromatograms were collected at 0.1 second intervals $(\mathrm{PW}=6)$. Graphs can be created by plotting every $10^{\text {th }}$ point $(<n>=10)$ or a voltage reading for every second of elapsed time. The program generates a column of relative voltages of the ECD but not the elapsed time. To convert the relative voltages to millivolts subtract 2000 then divide by 200 . The elapsed time has to be calculated in a worksheet from the $<\mathrm{n}>$ and the $<\mathrm{m}>$ parameters. An example of two chromatograms ID50015.RAW and ID42018.RAW (chromatogram \#1 and \#28 in appendix A) were produced in a Lotus 123 worksheet using the data output of CONVERT. Normalized chromatograms can be obtained if the time is normalized by the procedure described in appendix $\mathrm{C}$. 


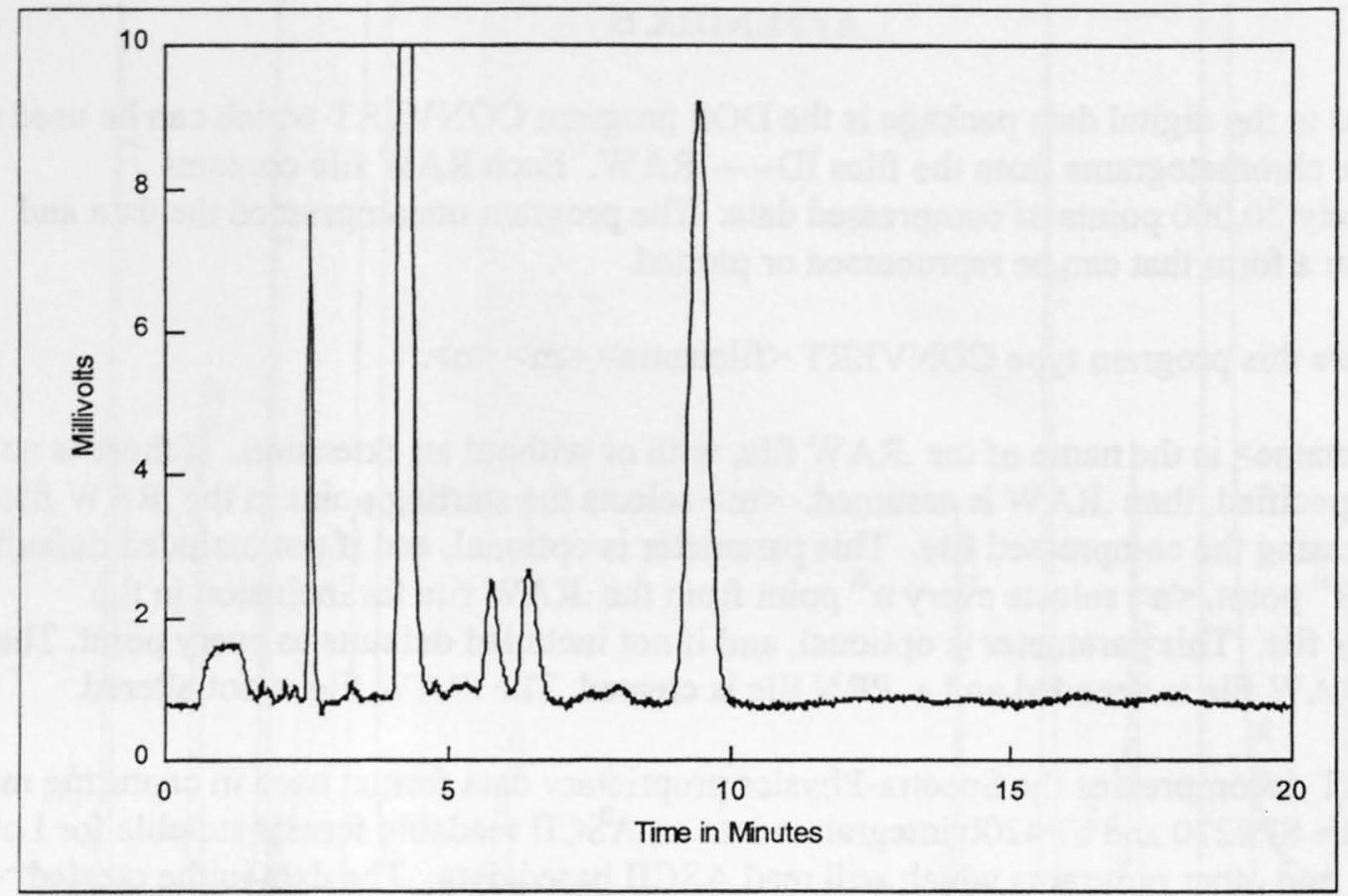

Well ANP 6, 10/14/94, Chromatogram No. 1

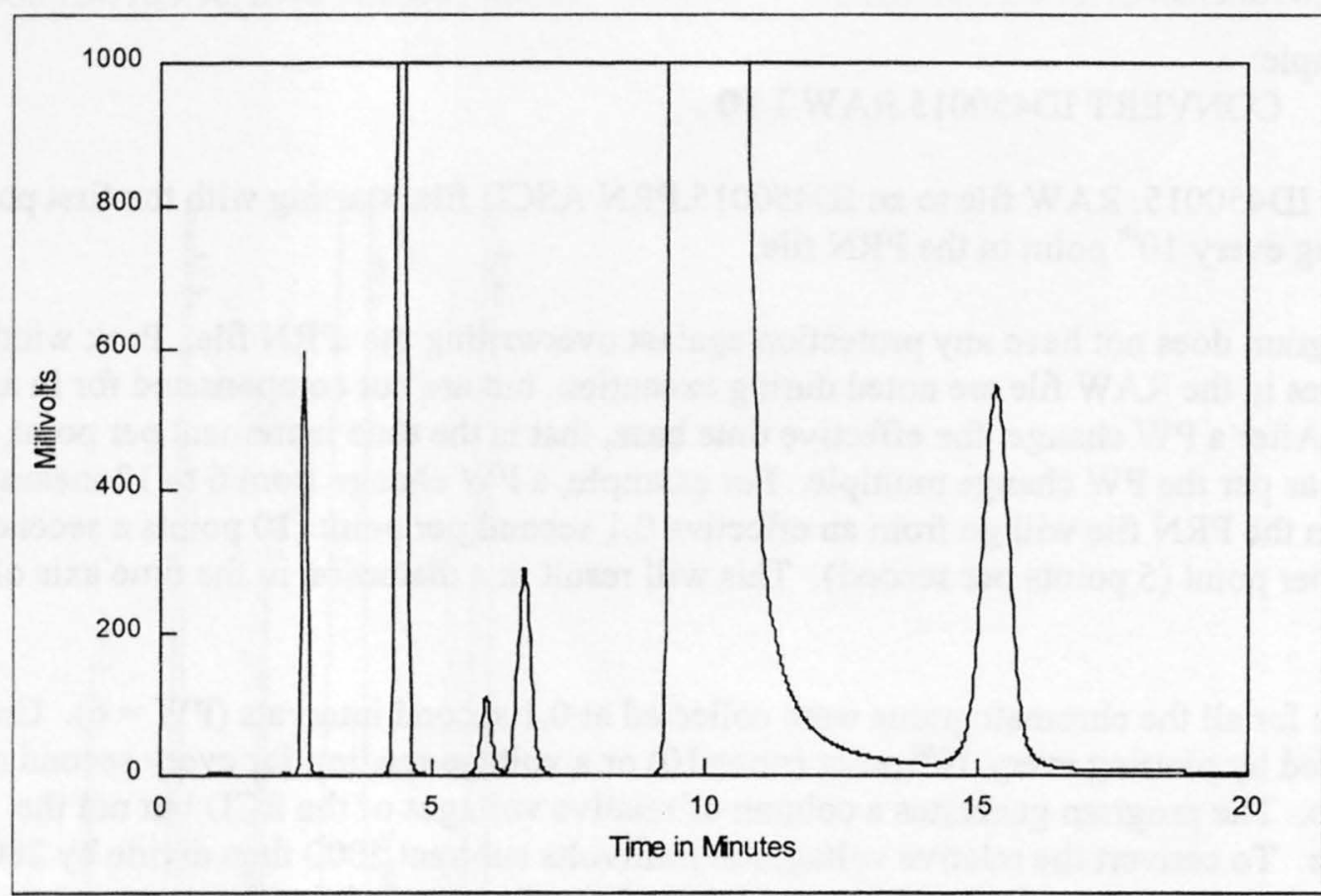

Well RWMC M3S, 7/22/96, Chromatogram No. 28

Example of chromatographs produced from the compressed digitized data. The integrator outputs for these two ground waters are given in appendix A. 


\section{APPENDIX C}

A procedure is described below that can be used to normalize the retention times of peaks in the chromatograms given in appendix A. The normalized retention times can be used to identify some of the halocarbons present in these chromatograms. Identification of halocabons based on retention times alone should be used with caution because different halocarbons can have very similar retention times. The observed retention times vary as a function of the GC oven temperature, the carrier flow rate, and other variables. Normalized retention times are corrected for all these variables. To normalize the retention time:

$$
n=[(r-0.50) f+0.50]
$$

where $n$ is the normalized retention time, $r$ is the observed retention time from appendix A, and $f$ is a conversion factor. The above equation can reproduce the normalized retention time of halocarbons with the accuracy given in the table below.

\begin{tabular}{lcc}
\hline $\begin{array}{l}\text { Name of } \\
\text { chromatograms }\end{array}$ & $\begin{array}{c}\text { Factor } \\
\boldsymbol{f}\end{array}$ & $\begin{array}{c}\text { Accuracy } \\
\text { (minutes) }\end{array}$ \\
\hline ID23---.RAW & 0.987859 & 0.03 \\
ID37--..RAW & .884387 & .03 \\
ID39--..RAW & .889662 & .03 \\
ID40--..RAW & .888779 & .03 \\
ID41--..RAW & .887017 & .03 \\
ID42---.RAW & .959271 & .03 \\
ID43--..RAW & .966523 & .03 \\
ID44--..RAW & .966523 & .03 \\
ID45--.RAW & .966523 & .03 \\
ID46--..RAW & .963402 & .03 \\
ID47---.RAW & .965480 & .03 \\
ID48---.RAW & .964440 & .03 \\
ID49--..RAW & 1.000000 & .03 \\
ID50--..RAW & 1.001119 & .03 \\
ID51---.RAW & 1.001119 & .03 \\
ID52---.RAW & 1.000000 & .03 \\
ID53--..RAW & 1.000000 & .03 \\
SC03--..RAW & .877451 & .20 \\
\hline
\end{tabular}


The normalized retention time for selected halocarbons present is some INEEL ground waters are presented in the table below. Halocarbons identification should be confirmed by gas chromatography-mass spectroscopy because numerous other halocarbons have retention times between 4 and 20 minutes.

\begin{tabular}{lc}
\hline Halocarbon & $\begin{array}{c}\text { Normalized } \\
\text { retention time } \\
\text { (minutes) }\end{array}$ \\
\hline $\mathrm{CFC}-12$ & 2.24 \\
$\mathrm{CFC}-11$ & 4.23 \\
$\mathrm{CH}{ }_{3} \mathrm{Cl}$ & 4.34 \\
$\mathrm{CFC}-113$ & 6.42 \\
$\mathrm{CCl}_{3} \mathrm{CH}_{3}$ & 6.6 \\
$\mathrm{CH}_{3} \mathrm{Br}$ & 6.8 \\
$\mathrm{CCl}_{4}$ & 9.5 \\
$\mathrm{CH}_{2} \mathrm{Cl}_{2}$ & 11.9 \\
$\mathrm{CHCl}_{3}$ & 14.8 \\
$\mathrm{C}_{2} \mathrm{HCl}_{3}$ & 15.4 \\
$\mathrm{C}_{2} \mathrm{Cl}_{4}$ & 18.9 \\
\hline
\end{tabular}


Table 1. Well production, well-construction data, and water levels of wells sampled in and near the Idaho National Engineering and Environmental Laboratory.

[All depths are below land surface; diam., diameter; galv., galvanized steel; ss, stainless steel; min, minutes; in, inches; ft, feet. Symbols: ---, not known or not applicable; , approximate]

\begin{tabular}{|c|c|c|c|c|c|c|c|c|c|c|c|c|}
\hline \multirow[b]{2}{*}{ Well name } & \multirow{2}{*}{$\begin{array}{l}\text { Pumping } \\
\text { rate } \\
\text { (gallons } \\
\text { per min) }\end{array}$} & \multirow{2}{*}{$\begin{array}{c}\text { Hole } \\
\text { diam. } \\
\text { (in) }\end{array}$} & \multirow{2}{*}{$\begin{array}{c}\text { Well } \\
\text { depth } \\
\text { (ft) }\end{array}$} & \multirow{2}{*}{$\begin{array}{l}\text { Depth of } \\
\text { intake } \\
\text { (ft) }\end{array}$} & \multirow{2}{*}{$\begin{array}{l}\text { Intake } \\
\text { diam. } \\
\text { (in) }\end{array}$} & \multirow{2}{*}{$\begin{array}{c}\text { Intake } \\
\text { material }\end{array}$} & \multicolumn{2}{|c|}{$\begin{array}{l}\text { Perforations } \\
\text { or open hole }\end{array}$} & \multicolumn{2}{|c|}{$\begin{array}{l}\text { Perforations } \\
\text { or open hole }\end{array}$} & \multirow{2}{*}{$\begin{array}{l}\text { Depth } \\
\text { of water } \\
\text { level } \\
\text { (ft) }\end{array}$} & \multirow{2}{*}{$\begin{array}{c}\text { Date } \\
\text { month/ } \\
\text { year }\end{array}$} \\
\hline & & & & & & & $\begin{array}{l}\text { top } \\
\text { (ft) }\end{array}$ & $\begin{array}{l}\text { length } \\
\text { (ft) }\end{array}$ & $\begin{array}{l}\text { top } \\
\text { (ft) }\end{array}$ & $\begin{array}{l}\text { length } \\
\text { (ft) }\end{array}$ & & \\
\hline$\overline{\text { ANP } 6}$ & 40 & 12 & 305 & 237 & 1.5 & galv. & 211 & 45 & 266 & 30 & 220 & $10 / 94$ \\
\hline ANP 9 & 20 & 12 & 322 & 270 & --- &.- & 237 & 77 & -- & -.- & 227 & $10 / 94$ \\
\hline Arbor Test & 20 & 16 & 790 & 720 & 1.5 & galv. & 680 & 50 & 737 & 50 & 682 & $4 / 95$ \\
\hline Arco City 2 & -- & -- & -- & 138 & -- & -- & -- & --- & -- & --- & $\sim 1622$ & -- \\
\hline Arco City 4 & 1,500 & 20 & 250 & 160 & --- & galv. & 209 & 8 & 225 & 17 & $\sim 132$ & $\ldots$ \\
\hline Area II * & 14 & 10 & 877 & 703 & 1.5 & ss & 676 & 47 & 752 & 62 & 673 & $7 / 94$ \\
\hline Atomic City & --- & 8 & 639 & 615 & --- & -- & 35 & 604 & -- & --- & 587 & $8 / 78$ \\
\hline BFW & 35 & 6 & 644 & -- & --- & -- & 533 & --- & -- & $\ldots$ & -491 & -.. \\
\hline CFA 1 & 1,000 & 16 & 685 & --- & --- &.- & 440 & 245 & - & $\cdots$ & 479 & $\ldots$ \\
\hline CFA 2 & 1,400 & 20 & 681 & -- & --- & -- & 521 & 130 & 661 & 20 & 471 & $12 / 48$ \\
\hline EBR I & 1,000 & 10 & 1,075 & --- & --- & -- & 675 & 75 & 750 & 325 & 586 & $\cdots$ \\
\hline Engberson & -- & 6 & 281 & 275 & --- & galv. & 109 & 172 & -- & -- & -- & --- \\
\hline Fire Station 2 & 400 & 16 & 518 & --- & --. & --. & 427 & 40 & 501 & 10 & 420 & $9 / 57$ \\
\hline IET 1 Disposal & 40 & 20 & 324 & 233 & 1.5 & galv. & 219 & 100 & -- & $\cdots$ & 214 & $7 / 94$ \\
\hline INEL-1 WS & 30 & 8 & 595 & 423 & 1.5 & galv. & 340 & 167 & 507 & 88 & 401 & $6 / 95$ \\
\hline Leo Rogers 1 & 20 & 20 & 702 & -- & -- & -- & 14 & 688 & -- & -- & 613 & $4 / 70$ \\
\hline Neville & -- & 6 & 85 & --- & --- & -- & -- & -- &.-- & $\cdots$ & -43 & $\cdots$ \\
\hline McKinney & -- & --- & 43 & -- & --- & -- & -- & --- & -- & $-\cdots$ & 8.8 & $7 / 91$ \\
\hline NPR Test & 26 & 6 & 599 & 486 & 1.5 & galv. & 500 & 35 & -- &.- & 467 & $4 / 95$ \\
\hline Park Bell & -- & -- & 48 & --- & -- & -- & -- & -- & -- & -- & $\sim 29$ & -.. \\
\hline PST & 44 & 16 & 322 & 242 & 1.5 & ss & 190 & 126 & -- & -- & 214 & $10 / 94$ \\
\hline P\&W2 & 35 & 10 & 386 & 342 & 1.5 & galv. & 313 & 70 & $\ldots$ & $\ldots$ & 317 & $10 / 94$ \\
\hline Pencheri 6 & $\cdots$ & 16 & 87 & -- &.- & -- & 37 & 40 & -- & -- & $\sim 25$ & -.. \\
\hline Ruby Farms & -- & --- & 650 & --- & --- & --- & 558 & 92 & -- & -- & $\sim 259$ & - \\
\hline RWMC M3S & 5 & 6 & 633 & 625 & --- & -- & 603 & 30 & -- & -- & 590 & $1 / 93$ \\
\hline RWMC M7S & 5 & 6 & 638 & 621 & --- & -- & 598 & 30 & -- & $\ldots$ & 576 & $7 / 96$ \\
\hline Squirrel & -- & -- & 232 & -- & -- & -- & -- & --- & -- & -- & $\sim 120$ & --- \\
\hline Site 04 & 500 & 15 & 496 & --- & -- & -- & 422 & 75 & -- & -- & 401 & -- \\
\hline Site 09 & 25 & 10 & 1,057 & 523 & 1.5 & ss & 681 & 376 & -- & -- & 475 & $7 / 94$ \\
\hline Site 14 & 40 & $8-10-12$ & 717 & 326 & 1.5 & ss & 535 & 181 & -- & -- & 276 & $10 / 94$ \\
\hline Site 17 & 25 & 20 & 600 & 442 & 1.5 & ss & 15 & 585 & -- & -- & 403 & $6 / 95$ \\
\hline Site $19^{*}$ & 25 & $18-10$ & 865 & 486 & 1.5 & galv. & 472 & 40 & 532 & 40 & 471 & $7 / 96$ \\
\hline TAN Exploration & 42 & 12 & 550 & 242 & 1.5 & ss & 267 & 283 & - & -- & 212 & $10 / 94$ \\
\hline USGS 001 & 16 & 6 & 636 & 612 & 1.5 & ss & 600 & 30 & -- & --- & 590 & $7 / 95$ \\
\hline USGS 002 & 16 & 5 & 704 & 683 & 1.5 & ss & 675 & 20 & -- & -- & 662 & $7 / 95$ \\
\hline USGS 004 & 40 & 6 & 553 & 303 & 1.5 & ss & 285 & 30 & 322 & 231 & 263 & $4 / 95$ \\
\hline USGS 005 & 5 & 6 & 500 & 488 & 1.5 & ss & 475 & 22 & -- & --- & 471 & $10 / 94$ \\
\hline USGS 006 & 25 & 6 & 620 & 461 & 1.3 & ss & 532 & 88 & -- & --- & 417 & $7 / 94$ \\
\hline USGS 007 & 45 & $4-6$ & 1,200 & 242 & 1.5 & ss & 239 & 20 & 760 & 440 & 217 & $10 / 94$ \\
\hline USGS 008 & 16 & 6 & 812 & 801 & 1.5 & ss & 782 & 30 & -- & -- & 770 & $10 / 94$ \\
\hline USGS 009 & 19 & 8 & 655 & 635 & 1.5 & galv. & 618 & 30 & 652 & 2 & 610 & $10 / 94$ \\
\hline USGS 011 & 22 & 12 & 704 & 687 & 1.5 & galv. & 673 & 31 & -- & --- & 655 & $4 / 95$ \\
\hline
\end{tabular}

* Area II has additional perforations at 854 feet with a length of 22 feet.

** Site 19 has additional perforations or open hole at 596 and 760 feet with lengths of 16 and 82 feet, respectively. 
Table 1. Well production, well-construction data, and water levels of wells sampled in and near the Idaho National Engineering and Environmental Laboratory - continued

\begin{tabular}{|c|c|c|c|c|c|c|c|c|c|c|c|c|}
\hline \multirow[b]{2}{*}{ Well name } & \multirow{2}{*}{$\begin{array}{l}\text { Pumping } \\
\text { rate } \\
\text { (gallons } \\
\text { per min) }\end{array}$} & \multirow{2}{*}{$\begin{array}{l}\text { Hole } \\
\text { diam. } \\
\text { (in) }\end{array}$} & \multirow{2}{*}{$\begin{array}{l}\text { Well } \\
\text { depth } \\
\text { (ft) }\end{array}$} & \multirow{2}{*}{$\begin{array}{l}\text { Depth of } \\
\text { intake } \\
\text { (ft) }\end{array}$} & \multirow{2}{*}{$\begin{array}{l}\text { Intake } \\
\text { diam. } \\
\text { (in) }\end{array}$} & \multirow{2}{*}{$\begin{array}{c}\text { Intake } \\
\text { material }\end{array}$} & \multicolumn{2}{|c|}{$\begin{array}{l}\text { Perforations } \\
\text { or open hole }\end{array}$} & \multicolumn{2}{|c|}{$\begin{array}{l}\text { Perforations } \\
\text { or open hole }\end{array}$} & \multirow{2}{*}{$\begin{array}{l}\text { Depth } \\
\text { of water } \\
\text { level } \\
\text { (ft) }\end{array}$} & \multirow{2}{*}{$\begin{array}{c}\text { Date } \\
\text { month } \\
\text { year }\end{array}$} \\
\hline & & & & & & & $\begin{array}{l}\text { top } \\
\text { (ft) }\end{array}$ & $\begin{array}{l}\text { length } \\
\text { (ft) }\end{array}$ & $\begin{array}{l}\text { top } \\
\text { (ft) }\end{array}$ & $\begin{array}{l}\text { length } \\
\text { (ft) }\end{array}$ & & \\
\hline$\overline{\text { USGS } 012}$ & 32 & $10-12$ & 563 & 358 & 1.5 & SS & $\cdots$ & -- & -- & - & 335 & $10 / 94$ \\
\hline USGS 014 & 16 & 6 & 751 & 739 & 1.5 & galv. & 720 & 3 & --- & -- & 717 & $10 / 94$ \\
\hline USGS 015 & 30 & $10-16$ & 610 & 358 & 1.5 & ss & 540 & 70 & --- & -- & 326 & $6 / 95$ \\
\hline USGS 017 & 32 & $6-8$ & 498 & 403 & 1.5 & ss & 438 & 7 & 496 & 2 & 359 & $10 / 94$ \\
\hline USGS 018 & 25 & 4 & 329 & 302 & 1.5 & ss & 298 & 24 & --- & -- & 275 & $7 / 94$ \\
\hline USGS 019 & 33 & 6 & 405 & 322 & 1.5 & ss & 285 & 21 & --- & -- & 279 & $10 / 94$ \\
\hline USGS 022 & 3 & 6 & 657 & 643 & 1.5 & ss & 644 & 13 & 619 & 15 & 614 & $6 / 95$ \\
\hline USGS 023 & 25 & 6 & 467 & 442 & 1.5 & ss & 410 & 20 & --. & -- & 405 & $10 / 94$ \\
\hline USGS 026 & 40 & 8 & 266 & 255 & 1.5 & ss & 232 & 35 & -- & $\ldots$ & 214 & $10 / 94$ \\
\hline USGS 027 & 20 & 8 & 312 & 262 & 1.5 & ss & 250 & 10 & 298 & 10 & 229 & $10 / 94$ \\
\hline USGS 029 & 32 & 6 & 426 & 402 & 1.5 & ss & 363 & 35 & 398 & 27 & 359 & $10 / 94$ \\
\hline USGS 031 & 40 & $8-10$ & 428 & 284 & 1.5 & ss & 285 & 20 & 306 & 122 & 259 & $10 / 94$ \\
\hline USGS 032 & 28 & $6-10$ & 392 & 322 & 1.5 & ss & 306 & 18 & 324 & 68 & 294 & $10 / 94$ \\
\hline USGS 036 & 25 & 6 & 567 & 521 & 1.5 & ss & 430 & 137 & -- & -- & 475 & $7 / 96$ \\
\hline USGS 037 & 25 & 8 & 573 & 506 & 1.5 & ss & 507 & 65 & --- & -- & 475 & $10 / 94$ \\
\hline USGS 058 & 26 & 6 & 503 & 476 & 1.5 & galv. & 218 & 285 & -- & -- & 460 & $7 / 91$ \\
\hline USGS 065 & 7 & 6 & 498 & 490 & 1.0 & galv. & 456 & 42 & --- & -- & 469 & $10 / 94$ \\
\hline USGS 076 & 25 & 6 & 718 & 502 & 1.5 & galv. & 487 & 261 & --- & -- & 477 & $10 / 94$ \\
\hline USGS 077 & 25 & 6 & 610 & 502 & 1.5 & ss & 470 & 140 & --- & -- & 467 & $10 / 94$ \\
\hline USGS 079 & 25 & 6 & 702 & 522 & 1.5 & ss & 470 & 140 & -- & -- & 475 & $7 / 91$ \\
\hline USGS 082 & 25 & 8 & 700 & 508 & 1.5 & galv. & 470 & 50 & 593 & 107 & 452 & $7 / 96$ \\
\hline USGS 083 & 6 & 6 & 752 & 606 & 1.0 & galv. & 516 & 236 & --- & --- & 501 & $4 / 95$ \\
\hline USGS 086 & 19 & 8 & 691 & 678 & 1.5 & galv. & 48 & 643 & --- & -- & 652 & $4 / 94$ \\
\hline USGS 089 & 5 & 6 & 646 & 620 & 1.0 & ss & 576 & 70 & --- & --- & 604 & $10 / 94$ \\
\hline USGS 097 & 27 & 4 & 510 & 402 & 1.5 & galv. & 388 & 122 & --- & -- & 386 & $6 / 95$ \\
\hline USGS 098 & 18 & 6 & 505 & 423 & 1.5 & galv. & 400 & 20 & 465 & 35 & 415 & $6 / 95$ \\
\hline USGS 099 & 25 & 6 & 450 & 427 & 1.5 & galv. & 303 & 146 & 449 & 1 & 400 & $6 / 95$ \\
\hline USGS 100 & 10 & 6 & 750 & 696 & 1.5 & galv. & 662 & 88 & -- & -- & 678 & $4 / 95$ \\
\hline USGS 101 & 13 & 6 & 865 & 790 & 1.5 & galv. & 750 & 115 & --- & --- & 773 & $4 / 95$ \\
\hline USGS 102 & 29 & 6 & 445 & 421 & 1.5 & ss & 359 & 86 & --- & --- & 378 & $6 / 95$ \\
\hline USGS 103 & 21 & 8 & 760 & 700 & 1.5 & galv. & 575 & 185 & --- & -- & 586 & $7 / 94$ \\
\hline USGS 104 & 21 & 8 & 700 & 592 & 1.5 & galv. & 550 & 150 & --- & - & 558 & $7 / 94$ \\
\hline USGS 105 & 19 & 8 & 800 & 700 & 1.5 & galv. & 400 & 400 & -- & -- & 672 & $10 / 94$ \\
\hline USGS 106 & 22 & 8 & 760 & 609 & 1.5 & galv. & 400 & 205 & 605 & 155 & 590 & $10 / 94$ \\
\hline USGS 107 & 25 & 8 & 690 & 531 & 1.5 & ss & 270 & 420 & -- & -- & 482 & $10 / 94$ \\
\hline USGS 108 & 20 & 8 & 760 & 637 & 1.5 & galv. & 400 & 360 & --- & --- & 611 & $10 / 94$ \\
\hline USGS 109 & 16 & 6 & 800 & 656 & 1.5 & galv. & 600 & 200 & --- & --- & 623 & $10 / 94$ \\
\hline USGS $110 \mathrm{~A}$ & 24 & 10 & 644 & 612 & 1.5 & ss & 240 & 417 & --- & -- & 566 & $10 / 96$ \\
\hline USGS 112 & 25 & 8 & 563 & 508 & 1.5 & galv. & 432 & 12 & 444 & 119 & 476 & $7 / 96$ \\
\hline USGS 113 & 25 & 6 & 564 & 508 & 1.5 & galv. & 445 & 59 & -- & --- & 477 & $7 / 96$ \\
\hline USGS 115 & 5 & 6 & 581 & 507 & 1.0 & galv. & 440 & 141 & --- & -- & 467 & $7 / 96$ \\
\hline USGS 116 & 20 & 6 & 580 & 508 & 1.5 & galv. & 438 & 142 &.-- & -- & 461 & $7 / 96$ \\
\hline USGS 117 & 2 & 8 & 655 & 625 & 1.0 & ss & 550 & 105 & --- & -- & 588 & $10 / 94$ \\
\hline USGS 119 & 3 & 8 & 705 & 685 & 1.5 & ss & 639 & 66 & --- & -- & 608 & $10 / 94$ \\
\hline USGS 120 & 21 & 8 & 705 & 665 & 1.0 & ss & 638 & 67 & --- & -- & 617 & $10 / 94$ \\
\hline USGS 121 & 8 & 8 & 475 & 460 & 1.0 & ss & 449 & 26 & --- & - & 458 & $10 / 94$ \\
\hline USGS 124 & 18 & 4 & 800 & 737 & 1.25 & ss & 750 & 50 & --- &.- & 686 & $7 / 94$ \\
\hline USGS 125 & 20 & 10 & 774 & 700 & 1.5 & ss & 620 & 154 & --- & -- & 630 & $6 / 95$ \\
\hline Wagoner Ranch & $-\cdots$ & -- & --- & --- & -- & --- & -- & -- & --- & -- & $\sim 11$ & -- \\
\hline
\end{tabular}


Table 2. Concentration of chlorofluorocarbons in ground water in and near the Idaho National Engineering and Environmental Laboratory.

[The calibration range of the gas chromatograph was 0 to $1,200,0$ to 2,500 , and $0-900 \mathrm{pg} / \mathrm{kg}$ for CFC-11, CFC-12 and CFC-113, respectively. Reported concentrations beyond the above calibration limits should be considered as qualitative estimates of concentrations. Location of wells is shown in figures 1,2 and 3. CFC-11, trichlorofluoromethane; CFC-12, dichlorodifluoromethane; CFC-113, trichlorotrifluoroethane; STD, standard deviation; $\mathrm{pg} / \mathrm{kg}$, picograms per kilogram of water; time 1310, 1:10 PM; ERR, concentration could not be determined]

\begin{tabular}{|c|c|c|c|c|c|c|c|c|c|c|c|}
\hline \multirow[b]{2}{*}{$\begin{array}{l}\text { Well } \\
\text { name }\end{array}$} & \multirow[b]{2}{*}{$\begin{array}{l}\text { Sampling } \\
\text { date }\end{array}$} & \multirow[b]{2}{*}{$\begin{array}{c}\text { Sampling } \\
\text { time }\end{array}$} & \multicolumn{3}{|c|}{ Concentration in water } & \multicolumn{3}{|c|}{ Average concentration } & \multicolumn{3}{|c|}{ Population STD } \\
\hline & & & $\begin{array}{l}\text { CFC-11 } \\
(\mathrm{pg} / \mathrm{kg})\end{array}$ & $\begin{array}{l}\text { CFC-12 } \\
(\mathrm{pg} / \mathrm{kg})\end{array}$ & $\begin{array}{c}\text { CFC-113 } \\
(\mathrm{pg} / \mathrm{kg})\end{array}$ & $\begin{array}{l}\text { CFC-11 } \\
(\mathrm{pg} / \mathrm{kg})\end{array}$ & $\begin{array}{c}\text { CFC-12 } \\
(\mathrm{pg} / \mathrm{kg})\end{array}$ & $\begin{array}{c}\text { CFC-113 } \\
(\mathrm{pg} / \mathrm{kg})\end{array}$ & $\begin{array}{l}\text { CFC-11 } \\
(\mathrm{pg} / \mathrm{kg})\end{array}$ & $\begin{array}{l}\text { CFC-12 } \\
(\mathrm{pg} / \mathrm{kg})\end{array}$ & $\begin{array}{c}\text { CFC-113 } \\
(\mathrm{pg} / \mathrm{kg})\end{array}$ \\
\hline ANP 6 & $10 / 14 / 94$ & 1130 & 161.2 & 96.0 & 44.0 & 162.6 & 94.1 & 45.9 & 1.0 & 2.9 & 2.0 \\
\hline ANP 6 & $10 / 14 / 94$ & 1137 & 163.5 & 90.0 & 48.6 & & & & & & \\
\hline ANP 6 & $10 / 14 / 94$ & 1141 & 163.0 & 96.3 & 45.0 & & & & & & \\
\hline$\overline{\text { ANP } 6}$ & $06 / 15 / 95$ & 1500 & 178.9 & 102.7 & 50.3 & 179.0 & 105.1 & 48.2 & 1.6 & 4.1 & 3.0 \\
\hline ANP 6 & $06 / 15 / 95$ & 1510 & 181.1 & 110.9 & 50.3 & & & & & & \\
\hline ANP 6 & $06 / 15 / 95$ & 1515 & 177.1 & 101.7 & 44.0 & & & & & & \\
\hline ANP 6 & $07 / 19 / 96$ & 0803 & 182.0 & 95.6 & 38.1 & 191.4 & 103.0 & 42.3 & 18.7 & 7.2 & 5.3 \\
\hline ANP 6 & $07 / 19 / 96$ & 0809 & 183.9 & 97.6 & 39.1 & & & & & & \\
\hline ANP 6 & $07 / 19 / 96$ & 0814 & 176.2 & 104.8 & ERR & & & & & & \\
\hline ANP 6 & $07 / 19 / 96$ & 0817 & 223.4 & 113.9 & 49.7 & & & & & & \\
\hline ANP 9 & $10 / 14 / 94$ & 1545 & 61.3 & 38.8 & 5.0 & 59.6 & 39.0 & 5.0 & 1.9 & 0.3 & 0.6 \\
\hline ANP 9 & $10 / 14 / 94$ & 1549 & 57.0 & 39.4 & 5.8 & & & & & & \\
\hline ANP 9 & $10 / 14 / 94$ & 1600 & 60.5 & 38.9 & 4.2 & & & & & & \\
\hline ANP 9 & $10 / 14 / 96$ & 1615 & 65.6 & 40.8 & 0.0 & 65.4 & 41.9 & 2.9 & 0.2 & 1.8 & 2.0 \\
\hline ANP 9 & $10 / 14 / 96$ & 1611 & 65.6 & 44.4 & 4.5 & & & & & & \\
\hline ANP 9 & $10 / 14 / 96$ & 1619 & 65.2 & 40.4 & 4.1 & & & & & & \\
\hline Arbor Test & $04 / 21 / 95$ & 1100 & 162.8 & 71.0 & 7.2 & 149.1 & 71.1 & 7.0 & 8.8 & 2.2 & 7.2 \\
\hline Arbor Test & $04 / 21 / 95$ & 1110 & 138.2 & 67.6 & 18.7 & & & & & & \\
\hline Arbor Test & $04 / 21 / 95$ & 1115 & 147.9 & 72.4 & 1.0 & & & & & & \\
\hline Arbor Test & $04 / 21 / 95$ & 1125 & 147.5 & 73.4 & 1.2 & & & & & & \\
\hline Arbor Test & $10 / 10 / 96$ & 1039 & 155.0 & 72.2 & 10.8 & 154.7 & 72.7 & 12.2 & 3.8 & 1.8 & 1.0 \\
\hline Arbor Test & $10 / 10 / 96$ & 1047 & 159.2 & 75.2 & 13.2 & & & & & & \\
\hline Arbor Test & $10 / 10 / 96$ & 1051 & 150.0 & 70.7 & 12.6 & & & & & & \\
\hline Area II & $07 / 19 / 94$ & 0926 & 83.5 & 38.8 & 6.3 & 81.2 & 40.1 & 3.0 & 2.3 & 1.4 & 2.6 \\
\hline Area II & $07 / 19 / 94$ & 0933 & 82.0 & 39.6 & 2.7 & & & & & & \\
\hline Area II & $07 / 19 / 94$ & 0940 & 78.0 & 42.0 & 0.0 & & & & & & \\
\hline Area II & $07 / 18 / 96$ & 0739 & 99.8 & 44.5 & 3.2 & 98.5 & 43.5 & 4.7 & 2.8 & 0.7 & 1.1 \\
\hline Area II & $07 / 18 / 96$ & 0746 & 101.1 & 43.4 & 5.2 & & & & & & \\
\hline Area II & $07 / 18 / 96$ & 0749 & 94.6 & 42.7 & 5.7 & & & & & & \\
\hline Atomic City & $10 / 03 / 94$ & 1135 & 268.2 & 138.7 & 31.8 & 271.5 & 137.5 & 32.5 & 7.3 & 1.8 & 2.3 \\
\hline Atomic City & $10 / 03 / 94$ & 1155 & 264.6 & 138.8 & 30.1 & & & & & & \\
\hline Atomic City & $10 / 03 / 94$ & 1158 & 281.6 & 135.0 & 35.6 & & & & & & \\
\hline Atomic City & $10 / 09 / 96$ & 1244 & 295.6 & 146.3 & 31.6 & 286.1 & 144.9 & 34.6 & 11.4 & 1.5 & 2.6 \\
\hline Atomic $\mathrm{Ci}$ & 9/96 & 1254 & 270.1 & 142.8 & 34.2 & & & & & & \\
\hline Atomic City & $10 / 09 / 96$ & 1258 & 292.6 & 145.7 & 38.0 & & & & & & \\
\hline
\end{tabular}


Table 2. Concentration of chlorofluorocarbons in ground water in and near the Idaho National Engineering and Environmental Laboratory--continued

\begin{tabular}{|c|c|c|c|c|c|c|c|c|c|c|c|}
\hline \multirow[b]{2}{*}{$\begin{array}{l}\text { Well } \\
\text { name }\end{array}$} & \multirow[b]{2}{*}{$\begin{array}{l}\text { Sampling } \\
\text { date }\end{array}$} & \multirow[b]{2}{*}{$\begin{array}{c}\text { Sampling } \\
\text { time }\end{array}$} & \multicolumn{3}{|c|}{ Concentration in water } & \multicolumn{3}{|c|}{ Average concentration } & \multicolumn{3}{|c|}{ Population STD } \\
\hline & & & $\begin{array}{l}\text { CFC-11 } \\
(\mathrm{pg} / \mathrm{kg})\end{array}$ & $\begin{array}{c}\text { CFC-12 } \\
(\mathrm{pg} / \mathrm{kg})\end{array}$ & $\begin{array}{c}\text { CFC-113 } \\
(\mathrm{pg} / \mathrm{kg})\end{array}$ & $\begin{array}{l}\text { CFC-11 } \\
(\mathrm{pg} / \mathrm{kg})\end{array}$ & $\begin{array}{l}\text { CFC-12 } \\
(\mathrm{pg} / \mathrm{kg})\end{array}$ & $\begin{array}{c}\text { CFC-113 } \\
(\mathrm{pg} / \mathrm{kg})\end{array}$ & $\begin{array}{l}\text { CFC-11 } \\
(\mathrm{pg} / \mathrm{kg})\end{array}$ & $\begin{array}{c}\text { CFC-12 } \\
(\mathrm{pg} / \mathrm{kg})\end{array}$ & $\begin{array}{c}\text { CFC-113 } \\
\text { (pg/kg) }\end{array}$ \\
\hline$\overline{\mathrm{BFW}}$ & $07 / 16 / 96$ & 1034 & 277.3 & 232.8 & ERR & 323.4 & 262.1 & ERR & 66.0 & 43.1 & $\overline{E R R}$ \\
\hline BFW & $07 / 16 / 96$ & 1042 & 276.1 & 230.6 & ERR & & & & & & \\
\hline BFW & $07 / 16 / 96$ & 1045 & 416.7 & 323.0 & 92.4 & & & & & & \\
\hline$\overline{\text { CFA } 1}$ & $07 / 16 / 96$ & 0954 & 1891.0 & 44730.7 & 446.5 & 1856.6 & 42027.3 & 476.6 & 172.9 & 4060.2 & 49.7 \\
\hline CFA 1 & $07 / 16 / 96$ & 1001 & 2049.0 & 45062.6 & 436.7 & & & & & & \\
\hline CFA 1 & $07 / 16 / 96$ & 1005 & 1629.8 & 36288.4 & 546.6 & & & & & & \\
\hline$\overline{\mathrm{CFA} 2}$ & $07 / 16 / 96$ & 0904 & 1646.6 & 192.9 & 336.9 & 2861.7 & 26423.6 & 831.6 & 1027.6 & 15161.6 & 306.7 \\
\hline CFA 2 & $07 / 16 / 96$ & 0907 & 3720.5 & 34804.2 & 844.2 & & & & & & \\
\hline CFA 2 & $07 / 16 / 96$ & 0911 & 4026.3 & 34374.3 & 985.5 & & & & & & \\
\hline CFA 2 & $07 / 16 / 96$ & 0915 & 2053.2 & 36323.1 & 1159.7 & & & & & & \\
\hline$\overline{\text { EBR I }}$ & $10 / 16 / 96$ & 1206 & 1.0 & 234.4 & 0.0 & 0.9 & 226.5 & 0.0 & 0.0 & 7.9 & 0.0 \\
\hline EBR I & $10 / 16 / 96$ & 1214 & 0.9 & 218.6 & 0.0 & & & & & & \\
\hline Fire Station 2 & $10 / 16 / 96$ & 1024 & 957.4 & 86.0 & 75.0 & 899.3 & 80.3 & 79.1 & 65.2 & 6.0 & 10.4 \\
\hline Fire Station 2 & $10 / 16 / 96$ & 1032 & 932.4 & 82.9 & 68.8 & & & & & & \\
\hline Fire Station 2 & $10 / 16 / 96$ & 1036 & 808.2 & 71.9 & 93.4 & & & & & & \\
\hline IET 1 Disposal & $07 / 18 / 94$ & 1236 & 21.3 & 119.4 & 9.3 & 26.7 & 124.2 & 3.1 & 8.0 & $\overline{4.5}$ & 4.4 \\
\hline IET 1 Disposal & $07 / 18 / 94$ & 1242 & 38.1 & 130.2 & 0.0 & & & & & & \\
\hline IET 1 Disposal & $07 / 18 / 94$ & 1300 & 20.8 & 123.0 & 0.0 & & & & & & \\
\hline IET 1 Disposal & $07 / 18 / 96$ & 1547 & 19.1 & 123.5 & 0.0 & 20.6 & 128.6 & 0.0 & 1.0 & 9.8 & 0.0 \\
\hline IET 1 Disposal & $07 / 18 / 96$ & 1549 & 20.0 & 122.3 & 0.0 & & & & & & \\
\hline IET 1 Disposal & $07 / 18 / 96$ & 1554 & 21.8 & 148.2 & 0.0 & & & & & & \\
\hline IET 1 Disposal & $07 / 18 / 96$ & 1622 & 20.9 & 124.2 & 0.0 & & & & & & \\
\hline IET 1 Disposal & $07 / 18 / 96$ & 1640 & 21.4 & 125.0 & 0.0 & & & & & & \\
\hline INEL 1 WS & $06 / 12 / 95$ & 1115 & 563.0 & 88.3 & 39.2 & 576.0 & 77.1 & 16.4 & 9.7 & 7.9 & 16.2 \\
\hline INEL 1 WS & $06 / 12 / 95$ & 1125 & 578.6 & 72.0 & 6.8 & & & & & & \\
\hline INELI WS & $06 / 12 / 95$ & 1130 & 586.4 & 71.0 & 3.3 & & & & & & \\
\hline Leo Rogers 1 & $07 / 17 / 96$ & 1318 & 132.4 & 73.9 & 20.6 & 128.9 & 72.8 & 15.7 & 3.7 & 1.4 & 3.6 \\
\hline Leo Rogers 1 & $07 / 17 / 96$ & 1326 & 130.6 & 73.7 & 14.8 & & & & & & \\
\hline Leo Rogers 1 & $07 / 17 / 96$ & 1329 & 123.8 & 70.8 & 11.8 & & & & & & \\
\hline NPR Test & $04 / 17 / 95$ & 1700 & 507.8 & 27.7 & 9.8 & 508.0 & 32.1 & 8.6 & 0.2 & 4.4 & 1.2 \\
\hline NPR Test & $04 / 17 / 95$ & 1710 & 508.2 & 36.5 & 7.4 & & & & & & \\
\hline NPR Test & $10 / 10 / 96$ & 1454 & 356.3 & 28.3 & 12.9 & 352.0 & 27.8 & 16.7 & 11.7 & 0.4 & 7.0 \\
\hline NPR Test & $10 / 10 / 96$ & 1502 & 363.7 & 27.5 & 10.8 & & & & & & \\
\hline NPR Test & $10 / 10 / 96$ & 1506 & 336.0 & 27.6 & 26.6 & & & & & & \\
\hline PSTF Test & $10 / 13 / 94$ & 1528 & 115.4 & 69.9 & 11.8 & 114.9 & 62.6 & 12.1 & 1.0 & 5.2 & 3.4 \\
\hline PSTF Test & $10 / 13 / 94$ & 1540 & 113.5 & 58.5 & 16.3 & & & & & & \\
\hline PSTF Test & $10 / 13 / 94$ & 1544 & 115.7 & 59.4 & 8.1 & & & & & & \\
\hline PSTF Test & $10 / 14 / 96$ & 1359 & 128.2 & 65.5 & 7.3 & 126.1 & 64.1 & 9.0 & 2.1 & 1.0 & 1.2 \\
\hline PSTF Test & $10 / 14 / 96$ & 1407 & 126.8 & 63.2 & 9.8 & & & & & & \\
\hline PSTF Test & $10 / 14 / 96$ & 1411 & 123.2 & 63.5 & 9.9 & & & & & & \\
\hline$\overline{P \& W} 2$ & $10 / 25 / 94$ & 1011 & 402.0 & 202.4 & 43.1 & 390.2 & 192.6 & 42.8 & 13.2 & 7.2 & 2.5 \\
\hline P\&W 2 & $10 / 25 / 94$ & 1017 & 396.7 & 190.2 & 45.7 & & & & & & \\
\hline P\&W 2 & $10 / 25 / 94$ & 1023 & 371.7 & 185.3 & 39.5 & & & & & & \\
\hline$\overline{P \& W} 2$ & $04 / 19 / 95$ & 1244 & 653.5 & 291.9 & 74.5 & 615.6 & 281.5 & 73.1 & 32.7 & 9.8 & 4.0 \\
\hline P\&W 2 & $04 / 19 / 95$ & 1249 & 619.7 & 268.4 & 67.7 & & & & & & \\
\hline P\&W 2 & $04 / 19 / 95$ & 1253 & 573.8 & 284.0 & 77.2 & & & & & & \\
\hline
\end{tabular}


Table 2. Concentration of chlorofluorocarbons in ground water in and near the Idaho National Engineering and Environmental Laboratory-continued

\begin{tabular}{|c|c|c|c|c|c|c|c|c|c|c|c|}
\hline \multirow[b]{2}{*}{$\begin{array}{l}\text { Well } \\
\text { name }\end{array}$} & \multirow[b]{2}{*}{$\begin{array}{c}\text { Sampling } \\
\text { date }\end{array}$} & \multirow[b]{2}{*}{$\begin{array}{c}\text { Sampling } \\
\text { time }\end{array}$} & \multicolumn{3}{|c|}{ Concentration in water } & \multicolumn{3}{|c|}{ Average concentration } & \multicolumn{3}{|c|}{ Population STD } \\
\hline & & & $\begin{array}{l}\text { CFC-11 } \\
(\mathrm{pg} / \mathrm{kg})\end{array}$ & $\begin{array}{l}\text { CFC-12 } \\
(\mathrm{pg} / \mathrm{kg})\end{array}$ & $\begin{array}{c}\text { CFC-113 } \\
(\mathrm{pg} / \mathrm{kg})\end{array}$ & $\begin{array}{l}\text { CFC-11 } \\
(\mathrm{pg} / \mathrm{kg})\end{array}$ & $\begin{array}{l}\text { CFC-12 } \\
(\mathrm{pg} / \mathrm{kg})\end{array}$ & $\begin{array}{c}\text { CFC-113 } \\
\text { (pg/kg) }\end{array}$ & $\begin{array}{l}\text { CFC-11 } \\
(\mathrm{pg} / \mathrm{kg})\end{array}$ & $\begin{array}{l}\text { CFC-12 } \\
(\mathrm{pg} / \mathrm{kg})\end{array}$ & $\begin{array}{c}\text { CFC-113 } \\
(\mathrm{pg} / \mathrm{kg})\end{array}$ \\
\hline$\overline{\mathrm{P} \& W 2}$ & $10 / 15 / 96$ & 1132 & 466.6 & 222.0 & 55.1 & 451.4 & 213.7 & 54.4 & 16.2 & 8.3 & 0.8 \\
\hline P\&W 2 & $10 / 15 / 96$ & 1140 & 458.7 & 216.8 & 53.3 & & & & & & \\
\hline P\&W 2 & $10 / 15 / 96$ & 1144 & 428.9 & 202.4 & 54.8 & & & & & & \\
\hline RWMC M3S & $07 / 22 / 96$ & 1118 & 3248.2 & 1728.6 & 8192.4 & 2566.3 & 7413.2 & 7783.3 & 715.7 & 4019.7 & 292.6 \\
\hline RWMC M3S & $07 / 22 / 96$ & 1126 & 2873.0 & 10272.9 & 7631.9 & & & & & & \\
\hline RWMC M3S & $07 / 22 / 96$ & 1129 & 1577.6 & 10238.2 & 7525.5 & & & & & & \\
\hline RWMC M7S & $07 / 22 / 96$ & 1023 & 4503.8 & 1609.3 & 13222.0 & 3670.4 & 1664.4 & 12993.5 & 1244.7 & 157.5 & 484.4 \\
\hline RWMC M7S & $07 / 22 / 96$ & 1031 & 4596.4 & 1505.1 & 13438.6 & & & & & & \\
\hline RWMC M7S & $07 / 22 / 96$ & 1034 & 1910.9 & 1878.8 & 12320.0 & & & & & & \\
\hline Site 04 & $10 / 06 / 96$ & 1402 & 347.6 & 43.0 & 13.6 & 336.6 & 41.4 & 18.6 & 11.0 & 1.5 & 5.0 \\
\hline Site 04 & $10 / 06 / 96$ & 1406 & 325.7 & 39.9 & 23.6 & & & & & & \\
\hline Site 09 & $07 / 22 / 96$ & 1223 & 40.4 & 17.3 & 0.0 & 41.7 & 16.5 & 1.0 & 1.4 & 0.7 & 1.4 \\
\hline Site 09 & $07 / 22 / 96$ & 1348 & 41.2 & 15.7 & 0.0 & & & & & & \\
\hline Site 09 & $07 / 22 / 96$ & 1352 & 43.6 & 16.6 & 3.0 & & & & & & \\
\hline Site 14 & $10 / 13 / 94$ & 1000 & 11.2 & 5.4 & 0.0 & 10.7 & 5.2 & 0.0 & 2.0 & 0.2 & 0.0 \\
\hline Site 14 & $10 / 13 / 94$ & 1012 & 8.0 & 5.3 & 0.0 & & & & & & \\
\hline Site 14 & $10 / 13 / 94$ & 1016 & 12.8 & 5.0 & 0.0 & & & & & & \\
\hline Site 14 & $10 / 14 / 96$ & 0849 & 9.7 & 7.8 & 0.0 & 8.0 & 6.5 & 0.0 & 1.2 & 2.0 & 0.0 \\
\hline Site 14 & $10 / 14 / 96$ & 0857 & 7.0 & 3.7 & 0.0 & & & & & & \\
\hline Site 14 & $10 / 14 / 96$ & 0901 & 7.4 & 7.9 & 0.0 & & & & & & \\
\hline Site 17 & $06 / 16 / 95$ & 1405 & 233.4 & 125.3 & 437.6 & 231.1 & 122.0 & 167.6 & 1.8 & 2.3 & 190.9 \\
\hline Site 17 & $06 / 16 / 95$ & 1415 & 229.0 & 120.1 & 35.6 & & & & & & \\
\hline Site 17 & $06 / 16 / 95$ & 1420 & 230.9 & 120.5 & 29.7 & & & & & & \\
\hline Site 19 & $07 / 21 / 94$ & 1458 & 38.8 & 12.0 & 0.0 & 37.0 & 12.0 & 0.9 & 1.5 & 0.6 & 1.5 \\
\hline Site 19 & 07/21/94 & 1506 & 38.2 & 11.5 & 0.0 & & & & & & \\
\hline Site 19 & $07 / 21 / 94$ & 1510 & 35.3 & 11.6 & 0.0 & & & & & & \\
\hline Site 19 & $07 / 21 / 94$ & 1514 & 35.8 & 13.0 & 3.4 & & & & & & \\
\hline$\overline{\text { Site } 19}$ & $07 / 16 / 96$ & 1219 & 429.4 & 118.8 & 24.4 & 422.7 & 116.0 & 28.3 & 7.0 & 2.2 & 3.8 \\
\hline Site 19 & $07 / 16 / 96$ & 1226 & 425.7 & 113.6 & 33.4 & & & & & & \\
\hline Site 19 & $07 / 16 / 96$ & 1230 & 413.1 & 115.5 & 27.2 & & & & & & \\
\hline TAN Expl. & $10 / 13 / 94$ & 1320 & 6.1 & 9.2 & 0.0 & 6.3 & 9.7 & 0.0 & 0.2 & 0.4 & 0.0 \\
\hline TAN Expl. & $10 / 13 / 94$ & 1332 & 6.6 & 10.0 & 0.0 & & & & & & \\
\hline TAN Expl. & $10 / 13 / 94$ & 1536 & 6.3 & 9.9 & 0.0 & & & & & & \\
\hline TAN Expl. & $10 / 14 / 96$ & 1205 & 5.6 & 5.6 & 0.0 & 8.3 & 9.8 & 0.0 & 2.2 & 3.1 & 0.0 \\
\hline TAN Expl. & $10 / 14 / 96$ & 1212 & 8.7 & 10.9 & 0.0 & & & & & & \\
\hline TAN Expl. & $10 / 14 / 96$ & 1216 & 10.8 & 12.9 & 0.0 & & & & & & \\
\hline USGS 001 & $10 / 03 / 94$ & 0948 & 62.5 & 34.1 & 6.1 & 61.8 & 35.4 & 6.0 & 0.6 & 1.0 & 2.6 \\
\hline USGS 001 & $10 / 03 / 94$ & 1020 & 62.0 & 36.5 & 9.2 & & & & & & \\
\hline USGS 001 & $10 / 03 / 94$ & 1025 & 60.9 & 35.5 & 2.7 & & & & & & \\
\hline USGS 001 & $10 / 09 / 96$ & 1518 & 71.2 & 38.2 & 6.5 & 72.3 & 38.7 & 8.0 & 1.0 & 0.5 & 3.8 \\
\hline USGS 001 & $10 / 09 / 96$ & 1526 & 72.0 & 38.5 & 4.3 & & & & & & \\
\hline USGS 001 & $10 / 09 / 96$ & 1529 & 73.7 & 39.3 & 13.2 & & & & & & \\
\hline USGS 002 & $07 / 19 / 94$ & 1124 & 127.8 & 64.0 & 6.7 & 129.6 & 64.9 & 9.6 & 1.3 & 0.8 & 2.6 \\
\hline USGS 002 & $07 / 19 / 94$ & 1133 & 130.9 & 64.9 & 9.1 & & & & & & \\
\hline USGS 002 & $07 / 19 / 94$ & 1142 & 130.1 & 65.9 & 13.0 & & & & & & \\
\hline
\end{tabular}


Table 2. Concentration of chlorofluorocarbons in ground water in and near the Idaho National Engineering and Environmental Laboratory-continued

\begin{tabular}{|c|c|c|c|c|c|c|c|c|c|c|c|}
\hline \multirow[b]{2}{*}{$\begin{array}{l}\text { Well } \\
\text { name }\end{array}$} & \multirow[b]{2}{*}{$\begin{array}{l}\text { Sampling } \\
\text { date }\end{array}$} & \multirow[b]{2}{*}{$\begin{array}{c}\text { Sampling } \\
\text { time }\end{array}$} & \multicolumn{3}{|c|}{ Concentration in water } & \multicolumn{3}{|c|}{ Average concentration } & \multicolumn{3}{|c|}{ Population STD } \\
\hline & & & $\begin{array}{l}\text { CFC-11 } \\
(\mathrm{pg} / \mathrm{kg})\end{array}$ & $\begin{array}{l}\text { CFC-12 } \\
(\mathrm{pg} / \mathrm{kg})\end{array}$ & $\begin{array}{c}\text { CFC-113 } \\
(\mathrm{pg} / \mathrm{kg})\end{array}$ & $\begin{array}{l}\text { CFC-11 } \\
(\mathrm{pg} / \mathrm{kg})\end{array}$ & $\begin{array}{l}\text { CFC-12 } \\
(\mathrm{pg} / \mathrm{kg})\end{array}$ & $\begin{array}{c}\text { CFC-113 } \\
(\mathrm{pg} / \mathrm{kg})\end{array}$ & $\begin{array}{l}\text { CFC-11 } \\
(\mathrm{pg} / \mathrm{kg})\end{array}$ & $\begin{array}{l}\text { CFC-12 } \\
(\mathrm{pg} / \mathrm{kg})\end{array}$ & $\begin{array}{c}\text { CFC-113 } \\
(\mathrm{pg} / \mathrm{kg})\end{array}$ \\
\hline USGS 002 & $07 / 17 / 96$ & 1532 & 160.0 & 76.0 & 10.6 & 156.3 & 73.7 & 10.1 & 4.0 & 1.7 & 1.4 \\
\hline USGS 002 & $07 / 17 / 96$ & 1539 & 158.2 & 73.1 & 11.5 & & & & & & \\
\hline USGS 002 & $07 / 17 / 96$ & 1543 & 150.7 & 72.1 & 8.3 & & & & & & \\
\hline USGS 004 & $10 / 24 / 94$ & 1412 & 440.3 & 265.3 & 13.1 & 447.4 & 259.1 & 18.4 & 12.7 & 4.5 & 7.0 \\
\hline USGS 004 & $10 / 24 / 94$ & 1440 & 465.3 & 257.5 & 28.3 & & & & & & \\
\hline USGS 004 & $10 / 24 / 94$ & 1447 & 436.8 & 254.7 & 13.9 & & & & & & \\
\hline USGS 004 & $04 / 19 / 95$ & 1455 & 447.4 & 284.0 & 24.1 & 444.8 & 281.7 & 25.5 & 2.7 & 1.6 & $\overline{4.2}$ \\
\hline USGS 004 & $04 / 19 / 95$ & 1505 & 441.1 & 281.0 & 21.2 & & & & & & \\
\hline USGS 004 & $04 / 19 / 95$ & 1510 & 445.8 & 280.2 & 31.2 & & & & & & \\
\hline USGS 004 & $10 / 15 / 96$ & 1724 & 456.9 & 228.6 & 19.1 & 467.8 & 250.8 & 25.7 & 26.1 & 25.8 & 5.3 \\
\hline USGS 004 & $10 / 15 / 96$ & 1732 & 503.9 & 287.0 & 32.1 & & & & & & \\
\hline USGS 004 & $10 / 15 / 96$ & 1736 & 442.7 & 236.8 & 25.8 & & & & & & \\
\hline USGS 005 & $10 / 12 / 94$ & 1300 & 111.6 & 69.3 & 16.7 & 109.1 & 65.0 & 15.6 & 1.8 & 3.9 & 3.7 \\
\hline USGS 005 & $10 / 12 / 94$ & 1312 & 107.9 & 59.9 & 19.5 & & & & & & \\
\hline USGS 005 & $10 / 12 / 94$ & 1316 & 107.9 & 65.9 & 10.6 & & & & & & \\
\hline USGS 005 & $10 / 10 / 96$ & 1658 & 72.8 & 43.5 & 9.7 & 75.8 & 44.4 & 9.2 & 4.9 & 2.9 & 1.6 \\
\hline USGS 005 & $10 / 10 / 96$ & 1702 & 72.1 & 41.3 & 7.0 & & & & & & \\
\hline USGS 005 & $10 / 10 / 96$ & 1706 & 82.7 & 48.3 & 10.9 & & & & & & \\
\hline USGS 006 & $07 / 19 / 94$ & 1456 & 0.0 & 0.0 & 0.0 & 0.0 & 0.0 & 0.0 & 0.0 & 0.0 & 0.0 \\
\hline USGS 006 & 07/19/94 & 1505 & 0.0 & 0.0 & 0.0 & & & & & & \\
\hline USGS 006 & $07 / 19 / 94$ & 1514 & 0.0 & 0.0 & 0.0 & & & & & & \\
\hline USGS 006 & $07 / 18 / 96$ & 1301 & 0.0 & 0.0 & 0.0 & 0.0 & 0.0 & 0.0 & 0.0 & 0.0 & $\overline{0.0}$ \\
\hline USGS 006 & $07 / 18 / 96$ & 1304 & 0.0 & 0.0 & 0.0 & & & & & & \\
\hline USGS 006 & $07 / 18 / 96$ & 1308 & 0.0 & 0.0 & 0.0 & & & & & & \\
\hline USGS 007 & $10 / 14 / 94$ & 0930 & 0.0 & 0.0 & 3.3 & 0.0 & 0.0 & 1.6 & 0.0 & 0.0 & 1.6 \\
\hline USGS 007 & $10 / 14 / 94$ & 0945 & 0.0 & 0.0 & 0.0 & & & & & & \\
\hline USGS 007 & $10 / 14 / 96$ & 1804 & 1.0 & 2.0 & 0.0 & 1.1 & 0.7 & 0.0 & 0.3 & 0.9 & $\overline{0.0}$ \\
\hline USGS 007 & $10 / 14 / 96$ & 1812 & 1.5 & 0.0 & 0.0 & & & & & & \\
\hline USGS 007 & $10 / 14 / 96$ & 1817 & 0.8 & 0.0 & 0.0 & & & & & & \\
\hline USGS 008 & $10 / 04 / 94$ & 1010 & 79.9 & 96.6 & 10.0 & 76.0 & 95.7 & 24.7 & 3.1 & 1.2 & 23.6 \\
\hline USGS 008 & $10 / 04 / 94$ & 1022 & 72.4 & 93.9 & 58.0 & & & & & & \\
\hline USGS 008 & $10 / 04 / 94$ & 1026 & 75.6 & 96.5 & 6.1 & & & & & & \\
\hline USGS 008 & $10 / 08 / 96$ & 1315 & 87.8 & 112.8 & 4.7 & 87.5 & 112.4 & 7.9 & 0.3 & 1.1 & 4.3 \\
\hline USGS 008 & $10 / 08 / 96$ & 1322 & 87.5 & 113.4 & 5.0 & & & & & & \\
\hline USGS 008 & $10 / 08 / 96$ & 1325 & 87.1 & 110.9 & 14.0 & & & & & & \\
\hline$\overline{\text { USGS } 009}$ & $10 / 04 / 94$ & 1355 & 288.4 & 201.2 & 47.4 & 226.7 & 180.8 & 42.9 & 35.6 & 12.6 & 3.6 \\
\hline USGS 009 & $10 / 04 / 94$ & 1404 & 205.1 & 166.7 & 45.4 & & & & & & \\
\hline USGS 009 & $10 / 04 / 94$ & 1408 & 205.0 & 176.9 & 40.2 & & & & & & \\
\hline USGS 009 & $10 / 04 / 94$ & 1413 & 208.4 & 178.6 & 38.7 & & & & & & \\
\hline USGS 009 & $04 / 20 / 95$ & 1442 & 205.5 & 197.7 & 40.1 & 200.7 & 180.6 & 38.6 & 3.7 & 12.7 & 3.8 \\
\hline USGS 009 & $04 / 20 / 95$ & 1446 & 203.2 & 187.6 & 42.8 & & & & & & \\
\hline USGS 009 & $04 / 20 / 95$ & 1450 & 196.8 & 165.8 & 32.5 & & & & & & \\
\hline USGS 009 & $04 / 20 / 95$ & 1454 & 197.5 & 171.1 & 38.9 & & & & & & \\
\hline
\end{tabular}


Table 2. Concentration of chlorofluorocarbons in ground water in and near the Idaho National Engineering and Environmental Laboratory-continued

\begin{tabular}{|c|c|c|c|c|c|c|c|c|c|c|c|}
\hline \multirow[b]{2}{*}{$\begin{array}{l}\text { Well } \\
\text { name }\end{array}$} & \multirow[b]{2}{*}{$\begin{array}{c}\text { Sampling } \\
\text { date }\end{array}$} & \multirow[b]{2}{*}{$\begin{array}{c}\text { Sampling } \\
\text { time }\end{array}$} & \multicolumn{3}{|c|}{ Concentration in water } & \multicolumn{3}{|c|}{ Average concentration } & \multicolumn{3}{|c|}{ Population STD } \\
\hline & & & $\begin{array}{l}\text { CFC-11 } \\
(\mathrm{pg} / \mathrm{kg})\end{array}$ & $\begin{array}{l}\text { CFC-12 } \\
\text { (pg/kg) }\end{array}$ & $\begin{array}{c}\text { CFC-113 } \\
(\mathrm{pg} / \mathrm{kg})\end{array}$ & $\begin{array}{l}\text { CFC-11 } \\
(\mathrm{pg} / \mathrm{kg})\end{array}$ & $\begin{array}{l}\text { CFC-12 } \\
(\mathrm{pg} / \mathrm{kg})\end{array}$ & $\begin{array}{c}\text { CFC-113 } \\
(\mathrm{pg} / \mathrm{kg})\end{array}$ & $\begin{array}{l}\text { CFC-11 } \\
(\mathrm{pg} / \mathrm{kg})\end{array}$ & $\begin{array}{l}\text { CFC-12 } \\
(\mathrm{pg} / \mathrm{kg})\end{array}$ & $\begin{array}{c}\text { CFC-113 } \\
\text { (pg/kg) }\end{array}$ \\
\hline USGS 009 & $10 / 11 / 96$ & 1304 & 546.5 & 276.9 & 72.2 & 333.8 & 198.0 & 58.6 & 150.5 & 55.8 & 14.8 \\
\hline USGS 009 & $10 / 11 / 96$ & 1312 & 231.1 & 160.8 & 38.0 & & & & & & \\
\hline USGS 009 & $10 / 11 / 96$ & 1316 & 223.6 & 156.3 & 65.6 & & & & & & \\
\hline USGS 011 & $04 / 20 / 95$ & 1129 & 107.7 & 98.0 & 27.3 & 108.6 & 99.7 & 29.4 & 1.5 & 1.4 & $\overline{4.0}$ \\
\hline USGS 011 & $04 / 20 / 95$ & 1137 & 110.8 & 101.4 & 25.9 & & & & & & \\
\hline USGS 011 & $04 / 20 / 95$ & 1141 & 107.4 & 99.7 & 35.0 & & & & & & \\
\hline USGS 011 & $10 / 09 / 96$ & 0833 & 113.9 & 119.0 & 39.8 & 112.8 & 116.3 & 39.3 & 1.2 & 2.4 & 1.8 \\
\hline USGS 011 & $10 / 09 / 96$ & 0840 & 113.3 & 116.9 & 36.9 & & & & & & \\
\hline USGS 011 & $10 / 09 / 96$ & 0845 & 111.1 & 113.1 & 41.3 & & & 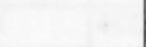 & & & \\
\hline USGS 012 & $10 / 27 / 94$ & 1330 & 218.2 & 95.7 & 11.6 & 222.2 & 95.9 & 15.0 & 3.7 & 3.4 & 2.6 \\
\hline USGS 012 & $10 / 27 / 94$ & 1401 & 221.3 & 100.1 & 15.4 & & & & & & \\
\hline USGS 012 & $10 / 27 / 94$ & 1407 & 227.0 & 91.9 & 17.8 & & & & & & \\
\hline USGS 012 & $06 / 14 / 95$ & 1520 & 228.8 & 101.5 & 10.5 & 229.6 & 98.9 & 10.9 & 0.7 & 2.6 & $\overline{0.4}$ \\
\hline USGS 012 & $06 / 14 / 95$ & 1535 & 230.3 & 96.3 & 11.3 & & & & & & \\
\hline USGS 014 & $10 / 26 / 94$ & 1000 & 169.6 & 236.8 & 17.2 & 170.5 & 240.8 & 18.7 & 0.7 & 6.6 & 2.4 \\
\hline USGS 014 & $10 / 26 / 94$ & 1022 & 170.4 & 235.5 & 22.1 & & & & & & \\
\hline USGS 014 & $10 / 26 / 94$ & 1036 & 171.4 & 250.1 & 16.9 & & & & & & \\
\hline USGS 014 & $10 / 09 / 96$ & 1016 & 188.8 & 236.0 & 24.4 & 184.2 & 231.6 & 23.2 & 5.9 & 3.2 & $\overline{3.6}$ \\
\hline USGS 014 & $10 / 09 / 96$ & 1024 & 188.0 & 228.7 & 18.2 & & & & & & \\
\hline USGS 014 & $10 / 09 / 96$ & 1027 & 175.8 & 230.0 & 26.8 & & & & & & \\
\hline USGS 015 & $06 / 14 / 95$ & 1220 & 12.3 & 8.1 & 2.5 & 12.0 & 8.8 & 0.8 & 0.3 & 1.0 & $\overline{1.2}$ \\
\hline USGS 015 & $06 / 14 / 95$ & 1230 & 12.0 & 10.2 & 0.0 & & & & & & \\
\hline USGS 015 & $06 / 14 / 95$ & 1235 & 11.6 & 8.0 & 0.0 & & & & & & \\
\hline USGS 017 & $10 / 27 / 94$ & 1005 & 45.2 & 18.6 & 3.6 & 44.1 & 19.1 & 2.8 & 1.1 & 0.5 & 0.7 \\
\hline USGS 017 & $10 / 27 / 94$ & 1020 & 43.1 & 19.5 & 2.1 & & & & & & \\
\hline USGS 017 & $06 / 13 / 95$ & 1440 & 48.4 & 25.1 & 1.2 & 48.2 & 21.2 & 1.9 & 0.6 & 3.1 & 2.0 \\
\hline USGS 017 & $06 / 13 / 95$ & 1450 & 48.9 & 20.8 & 0.0 & & & & & & \\
\hline USGS 017 & $06 / 13 / 95$ & 1455 & 47.3 & 17.6 & 4.6 & & & & & & \\
\hline USGS 018 & $07 / 18 / 94$ & 1451 & 16.3 & 8.9 & 0.0 & 15.3 & 11.3 & 0.0 & 0.9 & 2.2 & $\overline{0.0}$ \\
\hline USGS 018 & $07 / 18 / 94$ & 1458 & 15.6 & 14.3 & 0.0 & & & & & & \\
\hline USGS 018 & $07 / 18 / 94$ & 1506 & 14.2 & 10.8 & 0.0 & & & & & & \\
\hline USGS 018 & $07 / 19 / 96$ & 1629 & 19.3 & 16.3 & 0.0 & 21.9 & 14.5 & 1.2 & 4.0 & 2.3 & 1.7 \\
\hline USGS 018 & $07 / 19 / 96$ & 1636 & 18.9 & 11.2 & 3.6 & & & & & & \\
\hline USGS 018 & $07 / 19 / 96$ & 1641 & 27.6 & 15.9 & 0.0 & & & & & & \\
\hline USGS 019 & $10 / 25 / 94$ & 1227 & 153.4 & 101.9 & 47.7 & 232.7 & 133.6 & 38.4 & 108.8 & 42.0 & 10.5 \\
\hline USGS 019 & $10 / 25 / 94$ & 1052 & 158.2 & 106.0 & 23.8 & & & & & & \\
\hline USGS 019 & $10 / 25 / 94$ & 1259 & 386.5 & 193.0 & 43.7 & & & & & & \\
\hline USGS 019 & $04 / 19 / 95$ & 1055 & 155.2 & 102.7 & 23.6 & 160.4 & 105.4 & 14.5 & 5.7 & 2.7 & 8.4 \\
\hline USGS 019 & $04 / 19 / 95$ & 1058 & 166.8 & 108.7 & 8.7 & & & & & & \\
\hline USGS 019 & $04 / 19 / 95$ & 1102 & 154.4 & 102.6 & 21.9 & & & & & & \\
\hline USGS 019 & $04 / 19 / 95$ & 1106 & 165.3 & 107.6 & 3.8 & & & & & & \\
\hline
\end{tabular}


Table 2. Concentration of chlorofluorocarbons in ground water in and near the Idaho National Engineering and Environmental Laborator -continued

\begin{tabular}{|c|c|c|c|c|c|c|c|c|c|c|c|}
\hline \multirow[b]{2}{*}{$\begin{array}{l}\text { Well } \\
\text { name }\end{array}$} & \multirow[b]{2}{*}{$\begin{array}{l}\text { Sampling } \\
\text { date }\end{array}$} & \multirow[b]{2}{*}{$\begin{array}{c}\text { Sampling } \\
\text { time }\end{array}$} & \multicolumn{3}{|c|}{ Concentration in water } & \multicolumn{3}{|c|}{ Average concentration } & \multicolumn{3}{|c|}{ Population STD } \\
\hline & & & $\begin{array}{l}\text { CFC-11 } \\
(\mathrm{pg} / \mathrm{kg})\end{array}$ & $\begin{array}{l}\text { CFC-12 } \\
(\mathrm{pg} / \mathrm{kg})\end{array}$ & $\begin{array}{c}\text { CFC-113 } \\
(\mathrm{pg} / \mathrm{kg})\end{array}$ & $\begin{array}{l}\text { CFC-11 } \\
(\mathrm{pg} / \mathrm{kg})\end{array}$ & $\begin{array}{l}\text { CFC-12 } \\
(\mathrm{pg} / \mathrm{kg})\end{array}$ & $\begin{array}{c}\text { CFC-113 } \\
(\mathrm{pg} / \mathrm{kg})\end{array}$ & $\begin{array}{l}\text { CFC-11 } \\
(\mathrm{pg} / \mathrm{kg})\end{array}$ & $\begin{array}{l}\text { CFC-12 } \\
(\mathrm{pg} / \mathrm{kg})\end{array}$ & $\begin{array}{c}\text { CFC-113 } \\
(\mathrm{pg} / \mathrm{kg})\end{array}$ \\
\hline USGS 019 & $10 / 15 / 96$ & 0953 & 164.3 & 110.8 & 22.3 & 162.1 & 105.3 & 25.6 & 4.0 & 8.4 & 3.0 \\
\hline USGS 019 & $10 / 15 / 96$ & 0957 & 165.6 & 111.7 & 29.6 & & & & & & \\
\hline USGS 019 & $10 / 15 / 96$ & 1001 & 156.4 & 93.5 & 24.9 & & & & & & \\
\hline USGS 022 & $06 / 13 / 95$ & 0940 & 31.0 & 36.0 & 15.5 & 34.9 & 34.7 & 12.0 & 3.6 & 0.9 & 2.7 \\
\hline USGS 022 & $06 / 13 / 95$ & 0950 & 34.0 & 34.2 & 9.1 & & & & & & \\
\hline USGS 022 & $06 / 13 / 95$ & 0955 & 39.8 & 34.0 & 11.2 & & & & & & \\
\hline USGS 022 & $07 / 18 / 96$ & 1031 & 161.0 & 99.1 & 20.0 & 157.3 & 97.7 & 20.6 & 7.3 & 2.1 & $\overline{0.6}$ \\
\hline USGS 022 & $07 / 18 / 96$ & 1038 & 163.9 & 99.3 & 21.4 & & & & & & \\
\hline USGS 022 & $07 / 18 / 96$ & 1042 & 147.2 & 94.7 & 20.3 & & & & & & \\
\hline USGS 023 & $10 / 25 / 94$ & 1515 & 193.7 & 105.4 & 23.7 & 193.2 & 104.1 & 23.5 & 3.6 & 1.6 & 0.7 \\
\hline USGS 023 & $10 / 25 / 94$ & 1533 & 197.4 & 105.1 & 24.1 & & & & & & \\
\hline USGS 023 & $10 / 25 / 94$ & 1538 & 188.5 & 101.8 & 22.5 & & & & & & \\
\hline USGS 023 & $04 / 19 / 95$ & 0855 & 198.3 & 108.1 & 19.9 & 97.6 & 109.4 & 21.2 & 72.7 & 2.2 & $\overline{0.9}$ \\
\hline USGS 023 & $04 / 19 / 95$ & 0900 & 29.3 & 107.7 & 21.6 & & & & & & \\
\hline USGS 023 & $04 / 19 / 95$ & 0905 & 65.1 & 112.4 & 22.1 & & & & & & \\
\hline USGS 023 & $10 / 15 / 96$ & 0824 & 220.2 & 114.1 & 27.1 & 216.5 & 111.7 & 24.4 & 4.9 & 3.0 & 2.1 \\
\hline USGS 023 & $10 / 15 / 96$ & 0832 & 219.8 & 113.5 & 21.8 & & & & & & \\
\hline USGS 023 & $10 / 15 / 96$ & 0836 & 209.5 & 107.5 & 24.4 & & & & & & \\
\hline USGS 026 & $10 / 14 / 94$ & 1310 & 82.7 & 40.6 & 8.4 & 56.0 & 37.5 & 9.2 & 39.3 & 5.4 & $\overline{2.3}$ \\
\hline USGS 026 & $10 / 14 / 94$ & 1322 & 0.4 & 30.0 & 12.4 & & & & & & \\
\hline USGS 026 & $10 / 14 / 94$ & 1326 & 84.9 & 42.0 & 6.9 & & & & & & \\
\hline USGS 026 & $10 / 15 / 96$ & 1313 & 81.8 & 46.0 & 8.4 & 85.2 & 44.3 & 12.4 & 2.5 & 1.3 & 5.5 \\
\hline USGS 026 & $10 / 15 / 96$ & 1317 & 87.9 & 44.0 & 8.5 & & & & & & \\
\hline USGS 026 & $10 / 15 / 96$ & 1321 & 85.9 & 42.9 & 20.2 & & & & & & \\
\hline$\overline{\text { USGS } 027}$ & $10 / 11 / 94$ & 0938 & 38.9 & 22.1 & 3.8 & 37.1 & 22.3 & 3.0 & 2.8 & 0.4 & $\overline{2.2}$ \\
\hline USGS 027 & $10 / 11 / 94$ & 0950 & 33.1 & 22.8 & 5.4 & & & & & & \\
\hline USGS 027 & $10 / 11 / 94$ & 0954 & 39.3 & 22.1 & 0.0 & & & & & & \\
\hline USGS 027 & $10 / 15 / 96$ & 1454 & 41.5 & 24.7 & 2.2 & 41.4 & 22.5 & 0.7 & 0.4 & 2.6 & 1.1 \\
\hline USGS 027 & $10 / 15 / 96$ & 1458 & 41.8 & 23.8 & 0.0 & & & & & & \\
\hline USGS 027 & $10 / 15 / 96$ & 1502 & 40.8 & 18.8 & 0.0 & & & & & & \\
\hline$\overline{\text { USGS } 029}$ & $10 / 11 / 94$ & 1449 & 173.0 & 79.2 & 14.2 & 170.5 & 77.1 & 13.4 & 2.1 & 2.1 & $\overline{2.3}$ \\
\hline USGS 029 & $10 / 11 / 94$ & 1502 & 167.7 & 74.3 & 15.7 & & & & & & \\
\hline USGS 029 & $10 / 11 / 94$ & 1506 & 170.9 & 78.0 & 10.2 & & & & & & \\
\hline USGS 029 & $06 / 15 / 95$ & 1220 & 185.8 & 81.9 & 8.6 & 185.9 & 83.0 & 10.8 & 0.2 & 2.5 & $\overline{1.6}$ \\
\hline USGS 029 & $06 / 15 / 95$ & 1230 & 185.8 & 80.6 & 11.7 & & & & & & \\
\hline USGS 029 & $06 / 15 / 95$ & 1235 & 186.2 & 86.5 & 12.1 & & & & & & \\
\hline USGS 029 & $07 / 19 / 96$ & 1439 & 199.3 & 97.3 & 17.1 & 224.6 & 106.6 & 17.1 & 36.2 & 11.7 & $\overline{3.5}$ \\
\hline USGS 029 & $07 / 19 / 96$ & 1446 & 198.7 & 99.4 & 12.9 & & & & & & \\
\hline USGS 029 & $07 / 19 / 96$ & 1450 & 275.8 & 123.1 & 21.4 & & & & & & \\
\hline USGS 031 & $10 / 11 / 94$ & 1130 & 33.8 & 19.9 & 0.0 & 34.9 & 20.0 & 0.0 & 1.1 & 0.2 & $\overline{0.0}$ \\
\hline USGS 031 & $10 / 11 / 94$ & 1142 & 34.6 & 20.2 & 0.0 & & & & & & \\
\hline USGS 031 & $10 / 11 / 94$ & 1146 & 36.3 & 19.8 & 0.0 & & & & & & \\
\hline
\end{tabular}


Table 2. Concentration of chlorofluorocarbons in ground water in and near the Idaho National Engineering and Environmental Laboratory--continued

\begin{tabular}{|c|c|c|c|c|c|c|c|c|c|c|c|}
\hline \multirow[b]{2}{*}{$\begin{array}{l}\text { Well } \\
\text { name }\end{array}$} & \multirow[b]{2}{*}{$\begin{array}{c}\text { Sampling } \\
\text { date }\end{array}$} & \multirow[b]{2}{*}{$\begin{array}{c}\text { Sampling } \\
\text { time }\end{array}$} & \multicolumn{3}{|c|}{ Concentration in water } & \multicolumn{3}{|c|}{ Average concentration } & \multicolumn{3}{|c|}{ Population STD } \\
\hline & & & $\begin{array}{l}\text { CFC-11 } \\
(\mathrm{pg} / \mathrm{kg})\end{array}$ & $\begin{array}{l}\text { CFC-12 } \\
(\mathrm{pg} / \mathrm{kg})\end{array}$ & $\begin{array}{c}\text { CFC-113 } \\
(\mathrm{pg} / \mathrm{kg})\end{array}$ & $\begin{array}{l}\text { CFC-11 } \\
(\mathrm{pg} / \mathrm{kg})\end{array}$ & $\begin{array}{c}\text { CFC-12 } \\
(\mathrm{pg} / \mathrm{kg})\end{array}$ & $\begin{array}{c}\text { CFC-113 } \\
(\mathrm{pg} / \mathrm{kg})\end{array}$ & $\begin{array}{l}\text { CFC-11 } \\
(\mathrm{pg} / \mathrm{kg})\end{array}$ & $\begin{array}{l}\text { CFC-12 } \\
(\mathrm{pg} / \mathrm{kg})\end{array}$ & $\begin{array}{c}\text { CFC-113 } \\
(\mathrm{pg} / \mathrm{kg})\end{array}$ \\
\hline USGS 031 & $06 / 15 / 95$ & 0900 & 38.8 & 22.3 & 2.2 & 37.9 & 20.8 & 2.7 & 0.7 & 1.1 & 0.5 \\
\hline USGS 031 & $06 / 15 / 95$ & 0910 & 37.6 & 20.6 & 2.6 & & & & & & \\
\hline USGS 031 & $06 / 15 / 95$ & 0915 & 37.3 & 19.6 & 3.3 & & & & & & \\
\hline$\overline{\text { USGS } 031}$ & $07 / 19 / 96$ & 1150 & 42.9 & 23.2 & 0.0 & 43.0 & 23.3 & 3.7 & 1.9 & 0.5 & $\overline{5.2}$ \\
\hline USGS 031 & $07 / 19 / 96$ & 1156 & 45.4 & 22.8 & 11.0 & & & & & & \\
\hline USGS 031 & $07 / 19 / 96$ & 1200 & 40.7 & 23.9 & 0.0 & & & & & & \\
\hline USGS 032 & $10 / 11 / 94$ & 1309 & 61.5 & 50.0 & 9.3 & 65.7 & 48.1 & 7.0 & 3.1 & 1.4 & 1.7 \\
\hline USGS 032 & $10 / 11 / 94$ & 1317 & 67.4 & 47.0 & 6.1 & & & & & & \\
\hline USGS 032 & $10 / 11 / 94$ & 1321 & 68.4 & 47.2 & 5.6 & & & & & & \\
\hline USGS 032 & $06 / 15 / 95$ & 1035 & 66.9 & 47.9 & 7.2 & 65.3 & 46.8 & 6.5 & 1.2 & 1.2 & $\overline{0.9}$ \\
\hline USGS 032 & $06 / 15 / 95$ & 1045 & 64.6 & 45.1 & 7.0 & & & & & & \\
\hline USGS 032 & $06 / 15 / 95$ & 1050 & 64.3 & 47.4 & 5.3 & & & & & & \\
\hline USGS 032 & $07 / 19 / 96$ & 1311 & 70.4 & 48.1 & 0.0 & 72.9 & 48.2 & 2.3 & 3.9 & 2.4 & $\overline{3.3}$ \\
\hline USGS 032 & 07/19/96 & 1319 & 69.8 & 45.4 & 0.0 & & & & & & \\
\hline USGS 032 & $07 / 19 / 96$ & 1322 & 78.5 & 51.2 & 6.9 & & & & & & \\
\hline USGS 036 & $07 / 16 / 96$ & 1518 & 594.9 & 38741.1 & 139.1 & 590.5 & 35415.8 & 120.6 & 10.9 & 2777.9 & 17.9 \\
\hline USGS 036 & 07/16/96 & 1526 & 601.1 & 35564.8 & 126.5 & & & & & & \\
\hline USGS 036 & $07 / 16 / 96$ & 1530 & 575.6 & 31941.6 & 96.3 & & & & & & \\
\hline USGS 037 & $10 / 07 / 94$ & 1122 & 477.4 & 57561.2 & 205.1 & 483.8 & 55372.7 & 218.4 & 8.2 & 3888.4 & $\overline{18.0}$ \\
\hline USGS 037 & $10 / 07 / 94$ & 1132 & 495.4 & 49909.6 & 243.8 & & & & & & \\
\hline USGS 037 & $10 / 07 / 94$ & 1140 & 478.7 & 58647.3 & 206.3 & & & & & & \\
\hline USGS 065 & $10 / 12 / 94$ & 0952 & 1004.7 & 45531.8 & 227.0 & 1043.3 & 43647.2 & 243.2 & 76.4 & 1590.8 & $\overline{17.0}$ \\
\hline USGS 065 & $10 / 12 / 94$ & 0956 & 1005.3 & 44790.4 & 268.3 & & & & & & \\
\hline USGS 065 & $10 / 12 / 94$ & 1016 & 988.0 & 42716.3 & 228.1 & & & & & & \\
\hline USGS 065 & $10 / 12 / 94$ & 1015 & 1175.1 & 41550.3 & 249.4 & & & & & & \\
\hline USGS 076 & $10 / 12 / 94$ & 1308 & 667.2 & 1985.7 & 46.6 & 652.1 & 1955.4 & 44.9 & 16.5 & 26.4 & $\overline{3.1}$ \\
\hline USGS 076 & $10 / 12 / 94$ & 1320 & 629.1 & 1921.2 & 47.6 & & & & & & \\
\hline USGS 076 & $10 / 12 / 94$ & 1324 & 659.9 & 1959.3 & 40.5 & & & & & & \\
\hline USGS 077 & $10 / 07 / 94$ & 0938 & 250.4 & 52389.8 & ERR & 250.0 & 49339.5 & ERR & 1.2 & 3255.5 & $\overline{\text { ERR }}$ \\
\hline USGS 077 & $10 / 07 / 94$ & 0954 & 251.3 & 44827.9 & 125.7 & & & & & & \\
\hline USGS 077 & $10 / 07 / 94$ & 0958 & 248.4 & 50800.9 & ERR & & & & & & \\
\hline USGS 082 & $07 / 16 / 96$ & 1418 & 53.6 & 2925.1 & 6.0 & 54.8 & 2830.0 & 4.5 & 1.0 & 341.0 & $\overline{1.1}$ \\
\hline USGS 082 & $07 / 16 / 96$ & 1422 & 55.0 & 2373.1 & 3.3 & & & & & & \\
\hline USGS 082 & $07 / 16 / 96$ & 1430 & 56.0 & 3192.0 & 4.3 & & & & & & \\
\hline$\overline{\text { USGS } 083}$ & $04 / 17 / 95$ & 1509 & 8.1 & 4.6 & 0.0 & 9.3 & 6.3 & 1.3 & 0.9 & 1.6 & $\overline{1.9}$ \\
\hline USGS 083 & $04 / 17 / 95$ & 1515 & 9.6 & 8.4 & 0.0 & & & & & & \\
\hline USGS 083 & $04 / 17 / 95$ & 1520 & 10.3 & 6.0 & 3.9 & & & & & & \\
\hline USGS 086 & $10 / 04 / 94$ & 1155 & 38.8 & 18.1 & 5.7 & 46.1 & 23.1 & 7.6 & 6.3 & 3.8 & 2.5 \\
\hline USGS 086 & $10 / 04 / 94$ & 1208 & 45.6 & 24.0 & 11.2 & & & & & & \\
\hline USGS 086 & $10 / 04 / 94$ & 1213 & 54.1 & 27.1 & 6.0 & & & & & & \\
\hline USGS 086 & $10 / 11 / 96$ & 1452 & 578.9 & 302.7 & 85.4 & 251.8 & 129.4 & 51.2 & 232.9 & 123.0 & 34.7 \\
\hline USGS 086 & $10 / 11 / 96$ & 1504 & 121.7 & 56.0 & 64.5 & & & & & & \\
\hline USGS 086 & 10/11/96 & 1512 & 54.6 & 29.5 & 3.6 & & & & & & \\
\hline
\end{tabular}


Table 2. Concentration of chlorofluorocarbons in ground water in and near the Idaho National Engineering and Environmental Laboratory--continued

\begin{tabular}{|c|c|c|c|c|c|c|c|c|c|c|c|}
\hline \multirow[b]{2}{*}{$\begin{array}{l}\text { Well } \\
\text { name }\end{array}$} & \multirow[b]{2}{*}{$\begin{array}{c}\text { Sampling } \\
\text { date }\end{array}$} & \multirow[b]{2}{*}{$\begin{array}{c}\text { Sampling } \\
\text { time }\end{array}$} & \multicolumn{3}{|c|}{ Concentration in water } & \multicolumn{3}{|c|}{ Average concentration } & \multicolumn{3}{|c|}{ Population STD } \\
\hline & & & $\begin{array}{l}\text { CFC-11 } \\
(\mathrm{pg} / \mathrm{kg})\end{array}$ & $\begin{array}{c}\text { CFC-12 } \\
(\mathrm{pg} / \mathrm{kg})\end{array}$ & $\begin{array}{c}\text { CFC-113 } \\
\text { (pg/kg) }\end{array}$ & \begin{tabular}{|l|} 
CFC-11 \\
$(\mathrm{pg} / \mathrm{kg})$
\end{tabular} & $\begin{array}{l}\text { CFC-12 } \\
(\mathrm{pg} / \mathrm{kg})\end{array}$ & $\begin{array}{c}\text { CFC-113 } \\
(\mathrm{pg} / \mathrm{kg})\end{array}$ & $\begin{array}{l}\text { CFC-11 } \\
(\mathrm{pg} / \mathrm{kg})\end{array}$ & $\begin{array}{l}\text { CFC-12 } \\
(\mathrm{pg} / \mathrm{kg})\end{array}$ & $\begin{array}{c}\text { CFC-113 } \\
(\mathrm{pg} / \mathrm{kg})\end{array}$ \\
\hline USGS 089 & $10 / 07 / 94$ & 1402 & 86.9 & 9716.4 & 160.1 & 83.1 & 9617.3 & 155.7 & 5.7 & 191.8 & 10.7 \\
\hline USGS 089 & $10 / 07 / 94$ & 1418 & 87.4 & 9786.4 & 165.9 & & & & & & \\
\hline USGS 089 & $10 / 07 / 94$ & 1422 & 75.1 & 9349.1 & 141.0 & & & & & & \\
\hline USGS 089 & $07 / 17 / 96$ & 0922 & 145.0 & 876.9 & 156.7 & 132.6 & 920.4 & 132.2 & 8.9 & 43.6 & $\overline{17.4}$ \\
\hline USGS 089 & $07 / 17 / 96$ & 0929 & 127.9 & 964.0 & 120.3 & & & & & & \\
\hline USGS 089 & $07 / 17 / 96$ & 0933 & 124.8 & ERR & 119.4 & & & & & & \\
\hline USGS 097 & $06 / 13 / 95$ & 1120 & 4523.9 & 124.9 & 83.0 & 4255.9 & 122.1 & 71.1 & 203.3 & 2.1 & 8.4 \\
\hline USGS 097 & $06 / 13 / 95$ & 1130 & 4212.3 & 121.5 & 64.7 & & & & & & \\
\hline USGS 097 & $06 / 13 / 95$ & 1135 & 4031.6 & 120.0 & 65.8 & & & & & & \\
\hline USGS 098 & $06 / 12 / 95$ & 1240 & 540.5 & 80.1 & 76.6 & 578.0 & 81.8 & 36.7 & 26.7 & 2.4 & $\overline{29.0}$ \\
\hline USGS 098 & $06 / 12 / 95$ & 1250 & 593.4 & 80.1 & 8.9 & & & & & & \\
\hline USGS 098 & $06 / 12 / 95$ & 1255 & 600.2 & 85.2 & 24.5 & & & & & & \\
\hline USGS 099 & $06 / 12 / 95$ & 1432 & 4160.6 & 148.6 & 68.1 & 4249.6 & 151.9 & 70.8 & 112.6 & 4.2 & 4.8 \\
\hline USGS 099 & $06 / 12 / 95$ & 1440 & 4433.6 & 148.7 & 78.6 & & & & & & \\
\hline USGS 099 & $06 / 12 / 95$ & 1445 & 4155.0 & 159.0 & 65.9 & & & & & & \\
\hline USGS 099 & $06 / 12 / 95$ & 1450 & 4249.1 & 151.3 & 70.5 & & & & & & \\
\hline USGS 100 & $04 / 21 / 95$ & 1245 & 166.4 & 74.7 & 12.4 & 164.3 & 72.8 & 14.3 & 4.1 & 1.7 & 2.1 \\
\hline USGS 100 & $04 / 21 / 95$ & 1250 & 158.6 & 73.1 & 17.3 & & & & & & \\
\hline USGS 100 & $04 / 21 / 95$ & 1255 & 167.9 & 70.5 & 13.3 & & & & & & \\
\hline USGS 100 & $10 / 10 / 96$ & 1158 & 181.3 & 75.3 & 13.9 & 175.4 & 74.7 & 16.2 & 4.9 & 1.9 & $\overline{3.4}$ \\
\hline USGS 100 & $10 / 10 / 96$ & 1204 & 175.3 & 76.6 & 13.8 & & & & & & \\
\hline USGS 100 & $10 / 10 / 96$ & 1208 & 169.4 & 72.1 & 21.0 & & & & & & \\
\hline USGS 101 & $04 / 21 / 95$ & 1405 & 44.3 & 27.6 & 3.4 & 45.5 & 18.5 & 1.1 & 0.8 & 11.4 & 1.6 \\
\hline USGS 101 & $04 / 21 / 95$ & 1415 & 46.0 & 25.5 & 0.0 & & & & & & \\
\hline USGS 101 & $04 / 21 / 95$ & 1420 & 46.0 & 2.4 & 0.0 & & & & & & \\
\hline$\overline{\text { USGS } 101}$ & $10 / 10 / 96$ & 1319 & 48.2 & 26.4 & 3.1 & 47.6 & 26.8 & 3.4 & 2.1 & 0.4 & $\overline{0.5}$ \\
\hline USGS 101 & $10 / 10 / 96$ & 1323 & 44.7 & 26.8 & 4.1 & & & & & & \\
\hline USGS 101 & $10 / 10 / 96$ & 1331 & 49.8 & 27.3 & 3.0 & & & & & & \\
\hline USGS 102 & $06 / 13 / 95$ & 1240 & 6151.3 & 131.1 & 148.5 & 5795.6 & 140.8 & 279.7 & 276.1 & 9.7 & 187.4 \\
\hline USGS 102 & $06 / 13 / 95$ & 1245 & 5757.6 & 150.5 & 145.8 & & & & & & \\
\hline USGS 102 & $06 / 13 / 95$ & 1250 & 5478.1 & ERR & 544.8 & & & & & & \\
\hline USGS 103 & $07 / 20 / 94$ & 1231 & 137.2 & 119.5 & 8.4 & 95.5 & 121.0 & 10.1 & 59.8 & 1.2 & $\overline{2.0}$ \\
\hline USGS 103 & $07 / 20 / 94$ & 1235 & 11.0 & 120.9 & 12.8 & & & & & & \\
\hline USGS 103 & $07 / 20 / 94$ & 1239 & 138.3 & 122.5 & 9.0 & & & & & & \\
\hline USGS 103 & $04 / 18 / 95$ & 1113 & 134.8 & 125.4 & 7.8 & 136.4 & 125.3 & 10.7 & 1.7 & 0.7 & 3.5 \\
\hline USGS 103 & $04 / 18 / 95$ & 1117 & 135.5 & 124.4 & 15.6 & & & & & & \\
\hline USGS 103 & $04 / 18 / 95$ & 1121 & 138.8 & 126.1 & 8.5 & & & & & & \\
\hline USGS 103 & $07 / 15 / 96$ & 1133 & 258.5 & 182.5 & 34.3 & 246.6 & 170.7 & 31.0 & 9.9 & 8.3 & 2.9 \\
\hline USGS 103 & $07 / 15 / 96$ & 1141 & 247.3 & 165.2 & 31.6 & & & & & & \\
\hline USGS 103 & $07 / 15 / 96$ & 1145 & 234.1 & 164.5 & 27.2 & & & & & & \\
\hline USGS 104 & $07 / 20 / 94$ & 0952 & 131.4 & 21391.6 & 45.4 & 131.0 & 21546.0 & 43.6 & 0.3 & 162.6 & 1.4 \\
\hline USGS 104 & $07 / 20 / 94$ & 0958 & 130.5 & 21475.5 & 43.2 & & & & & & \\
\hline USGS 104 & $07 / 20 / 94$ & 1004 & 131.1 & 21770.8 & 42.1 & & & & & & \\
\hline
\end{tabular}


Table 2. Concentration of chlorofluorocarbons in ground water in and near the Idaho National Engineering and Environmental Laboratory-continued

\begin{tabular}{|c|c|c|c|c|c|c|c|c|c|c|c|}
\hline \multirow[b]{2}{*}{$\begin{array}{l}\text { Well } \\
\text { name }\end{array}$} & \multirow[b]{2}{*}{$\begin{array}{c}\text { Sampling } \\
\text { date }\end{array}$} & \multirow[b]{2}{*}{$\begin{array}{c}\text { Sampling } \\
\text { time }\end{array}$} & \multicolumn{3}{|c|}{ Concentration in water } & \multicolumn{3}{|c|}{ Average concentration } & \multicolumn{3}{|c|}{ Population STD } \\
\hline & & & $\begin{array}{c}\text { CFC-11 } \\
(\mathrm{pg} / \mathrm{kg})\end{array}$ & $\begin{array}{c}\text { CFC-12 } \\
(\mathrm{pg} / \mathrm{kg})\end{array}$ & $\begin{array}{c}\text { CFC-113 } \\
(\mathrm{pg} / \mathrm{kg})\end{array}$ & $\begin{array}{l}\text { CFC-11 } \\
(\mathrm{pg} / \mathrm{kg})\end{array}$ & $\begin{array}{l}\text { CFC-12 } \\
(\mathrm{pg} / \mathrm{kg})\end{array}$ & $\begin{array}{c}\text { CFC-113 } \\
(\mathrm{pg} / \mathrm{kg})\end{array}$ & $\begin{array}{l}\text { CFC-11 } \\
(\mathrm{pg} / \mathrm{kg})\end{array}$ & $\begin{array}{l}\text { CFC-12 } \\
(\mathrm{pg} / \mathrm{kg})\end{array}$ & $\begin{array}{c}\text { CFC-113 } \\
(\mathrm{pg} / \mathrm{kg})\end{array}$ \\
\hline USGS 104 & $04 / 18 / 95$ & 0907 & 103.9 & 20540.3 & 38.9 & 172.6 & 9657.9 & 30.7 & 172.6 & 8402.9 & 22.1 \\
\hline USGS 104 & $04 / 18 / 95$ & 0911 & 409.7 & 8351.3 & 52.7 & & & & & & \\
\hline USGS 104 & $04 / 18 / 95$ & 0925 & 4.0 & 82.2 & 0.5 & & & & & & \\
\hline USGS 104 & $07 / 15 / 96$ & 0947 & 124.7 & $\overline{3294.4}$ & 42.8 & 122.2 & 7712.8 & 37.8 & 2.5 & 6249.2 & $\overline{7.2}$ \\
\hline USGS 104 & $07 / 15 / 96$ & 0955 & 123.0 & 3293.5 & 43.1 & & & & & & \\
\hline USGS 104 & $07 / 15 / 96$ & 0959 & 118.9 & 16550.4 & 27.6 & & & & & & \\
\hline USGS 105 & $10 / 03 / 94$ & 1445 & 503.3 & 2296.0 & 1041.0 & 514.1 & 2301.8 & 1031.8 & 21.5 & 105.1 & 19.7 \\
\hline USGS 105 & $10 / 03 / 94$ & 1500 & 544.1 & 2433.3 & 1049.9 & & & & & & \\
\hline USGS 105 & $10 / 03 / 94$ & 1505 & 494.8 & 2176.0 & 1004.4 & & & & & & \\
\hline USGS 105 & $04 / 18 / 95$ & 1535 & 512.4 & 2472.6 & 961.8 & 457.4 & 2626.1 & 1028.8 & 39.8 & 119.4 & $\overline{61.1}$ \\
\hline USGS 105 & $04 / 18 / 95$ & 1129 & 419.9 & 2763.8 & 1015.0 & & & & & & \\
\hline USGS 105 & $04 / 18 / 95$ & 1545 & 439.9 & 2641.9 & 1109.5 & & & & & & \\
\hline USGS 106 & $10 / 05 / 94$ & 1227 & 342.2 & 8578.1 & 30.0 & 340.1 & 8593.4 & 32.6 & 1.9 & 14.6 & 2.8 \\
\hline USGS 106 & $10 / 05 / 94$ & 1242 & 340.5 & 8613.0 & 31.3 & & & & & & \\
\hline USGS 106 & $10 / 05 / 94$ & 1246 & 337.5 & 8589.1 & 36.6 & & & & & & \\
\hline USGS 107 & $10 / 05 / 94$ & 0955 & 112.0 & 80.6 & 13.4 & 100.3 & 73.1 & 11.5 & 14.1 & 10.3 & $\overline{2.1}$ \\
\hline USGS 107 & $10 / 05 / 94$ & 1007 & 108.5 & 80.1 & 12.5 & & & & & & \\
\hline USGS 107 & $10 / 05 / 94$ & 1011 & 80.4 & 58.5 & 8.6 & & & & & & \\
\hline USGS 107 & $10 / 09 / 96$ & 1659 & 120.6 & 89.0 & 12.4 & 121.2 & 90.5 & 11.4 & 1.5 & 2.1 & $\overline{2.1}$ \\
\hline USGS 107 & 10/09/96 & 1707 & 123.3 & 93.6 & 13.3 & & & & & & \\
\hline USGS 107 & $10 / 09 / 96$ & 1711 & 119.6 & 89.0 & 8.6 & & & & & & \\
\hline USGS 108 & $10 / 03 / 94$ & 1700 & 126.2 & 650.4 & 0.0 & 126.9 & 657.4 & 3.7 & 3.1 & 9.6 & $\overline{5.2}$ \\
\hline USGS 108 & $10 / 03 / 94$ & 1728 & 131.1 & 671.0 & 11.1 & & & & & & \\
\hline USGS 108 & $10 / 03 / 94$ & 1735 & 123.5 & 650.8 & 0.0 & & & & & & \\
\hline USGS 108 & $04 / 18 / 95$ & 1340 & 126.3 & 642.0 & 8.4 & 128.8 & 654.8 & 8.5 & 3.3 & 10.3 & $\overline{0.9}$ \\
\hline USGS 108 & $18 / 95$ & 1345 & 133.5 & 667.4 & 7.4 & & & & & & \\
\hline USGS 108 & $04 / 18 / 95$ & 1350 & 126.8 & 655.1 & 9.7 & & & & & & \\
\hline USGS 109 & $10 / 04 / 94$ & 1555 & 304.3 & 791.0 & 455.8 & 321.4 & 802.7 & 443.6 & 12.3 & 8.2 & $\overline{13.5}$ \\
\hline USGS 109 & $10 / 04 / 94$ & 1607 & 333.0 & 808.5 & 424.8 & & & & & & \\
\hline USGS 109 & $10 / 04 / 94$ & 1612 & 326.9 & 808.4 & 450.2 & & & & & & \\
\hline USGS 109 & $04 / 20 / 95$ & 1327 & 342.8 & 904.0 & 546.6 & 346.3 & 898.7 & 514.3 & 13.7 & 16.7 & 31.0 \\
\hline USGS 109 & $0 / 95$ & 1338 & 331.6 & 916.0 & 523.9 & & & & & & \\
\hline USGS 109 & $04 / 20 / 95$ & 1342 & 364.6 & 876.2 & 472.5 & & & & & & \\
\hline USGS 109 & $10 / 11 / 96$ & 1142 & 382.9 & 1007.0 & 520.1 & 411.6 & 1005.1 & 553.4 & 64.7 & 16.0 & 23.8 \\
\hline USGS 109 & $10 / 11 / 96$ & 1150 & 501.1 & 1023.7 & 565.3 & & & & & & \\
\hline USGS 109 & $10 / 11 / 96$ & 1154 & 350.7 & 984.6 & 574.7 & & & & & & \\
\hline USGS $110 \mathrm{~A}$ & $10 / 09 / 96$ & 1414 & 143.1 & 79.8 & 10.6 & 144.1 & 78.3 & 18.5 & 0.8 & 1.1 & $\overline{8.0}$ \\
\hline USGS $110 \mathrm{~A}$ & $10 / 09 / 96$ & 1421 & 145.1 & 78.1 & 15.4 & & & & & & \\
\hline USGS $110 \mathrm{~A}$ & $10 / 09 / 96$ & 1425 & 144.2 & 77.1 & 29.5 & & & & & & \\
\hline USGS 112 & $07 / 15 / 96$ & 1304 & 467.1 & 45501.9 & 277.4 & 463.5 & 48253.3 & 244.8 & 11.6 & 2957.5 & 79.4 \\
\hline USGS 112 & $07 / 15 / 96$ & 1310 & 475.5 & 46900.9 & 321.4 & & & & & & \\
\hline USGS 112 & $07 / 15 / 96$ & 1315 & 447.8 & 52357.1 & 135.4 & & & & & & \\
\hline
\end{tabular}


Table 2. Concentration of chlorofluorocarbons in ground water in and near the Idaho National Engineering and Environmental Laboratory-continued

\begin{tabular}{|c|c|c|c|c|c|c|c|c|c|c|c|}
\hline \multirow[b]{2}{*}{$\begin{array}{l}\text { Well } \\
\text { name }\end{array}$} & \multirow[b]{2}{*}{$\begin{array}{c}\text { Sampling } \\
\text { date }\end{array}$} & \multirow[b]{2}{*}{$\begin{array}{c}\text { Sampling } \\
\text { time }\end{array}$} & \multicolumn{3}{|c|}{ Concentration in water } & \multicolumn{3}{|c|}{ Average concentration } & \multicolumn{3}{|c|}{ Population STD } \\
\hline & & & $\begin{array}{l}\text { CFC-11 } \\
(\mathrm{pg} / \mathrm{kg})\end{array}$ & $\begin{array}{l}\text { CFC-12 } \\
(\mathrm{pg} / \mathrm{kg})\end{array}$ & $\begin{array}{c}\text { CFC-113 } \\
(\mathrm{pg} / \mathrm{kg})\end{array}$ & $\begin{array}{l}\text { CFC-11 } \\
(\mathrm{pg} / \mathrm{kg})\end{array}$ & $\begin{array}{l}\text { CFC-12 } \\
(\mathrm{pg} / \mathrm{kg})\end{array}$ & $\begin{array}{c}\text { CFC-113 } \\
(\mathrm{pg} / \mathrm{kg})\end{array}$ & $\begin{array}{l}\text { CFC-11 } \\
(\mathrm{pg} / \mathrm{kg})\end{array}$ & $\begin{array}{l}\text { CFC-12 } \\
(\mathrm{pg} / \mathrm{kg})\end{array}$ & $\begin{array}{c}\text { CFC-113 } \\
(\mathrm{pg} / \mathrm{kg})\end{array}$ \\
\hline USGS 113 & $07 / 16 / 96$ & 1605 & 408.6 & 6811.3 & ERR & 398.9 & 19501.6 & ERR & 13.5 & 17749.9 & ERR \\
\hline USGS 113 & $07 / 16 / 96$ & 1612 & 408.3 & 7090.1 & ERR & & & & & & \\
\hline USGS 113 & $07 / 16 / 96$ & 1616 & 379.9 & 44603.3 & 130.3 & & & & & & \\
\hline USGS 115 & $07 / 15 / 96$ & 1503 & 172.2 & 28744.7 & 57.6 & 203.3 & 24043.8 & 40.8 & 22.1 & 3866.7 & 14.0 \\
\hline USGS 115 & $07 / 15 / 96$ & 1507 & 222.0 & 24112.8 & 41.4 & & & & & & \\
\hline USGS 115 & $07 / 15 / 96$ & 1511 & 215.8 & 19273.9 & 23.2 & & & & & & \\
\hline USGS 116 & $07 / 15 / 96$ & 1601 & 236.0 & 1951.9 & 36.3 & 218.0 & 2759.0 & 35.9 & 16.1 & 659.2 & 10. \\
\hline USGS 116 & $07 / 15 / 96$ & 1608 & 221.0 & 2758.6 & 48.6 & & & & & & \\
\hline USGS 116 & $07 / 15 / 96$ & 1612 & 196.9 & 3566.6 & 22.9 & & & & & & \\
\hline USGS 117 & $10 / 05 / 94$ & 1530 & 56.2 & 25.1 & 14.3 & 55.6 & 25.3 & 14.1 & 1.8 & 1.5 & 2. \\
\hline USGS 117 & $10 / 05 / 94$ & 1541 & 57.4 & 27.3 & 16.9 & & & & & & \\
\hline USGS 117 & $10 / 05 / 94$ & 1546 & 53.2 & 23.7 & 11.2 & & & & & & \\
\hline USGS 117 & $07 / 17 / 96$ & 0804 & 20.8 & 12.2 & 0.0 & 18.5 & 9.1 & 1.3 & 1.8 & 2.6 & 1 . \\
\hline USGS 117 & $07 / 17 / 96$ & 0810 & 18.1 & 9.1 & 0.0 & & & & & & \\
\hline USGS 117 & $07 / 17 / 96$ & 0814 & 16.4 & 5.9 & 3.8 & & & & & & \\
\hline USGS 119 & $10 / 06 / 94$ & 1336 & 381.8 & 749.3 & 2780.2 & 384.4 & 743.8 & 2649.3 & 2.6 & 5.6 & 131.0 \\
\hline USGS 119 & $10 / 06 / 94$ & 1340 & 387.0 & 738.2 & 2518.3 & & & & & & \\
\hline USGS 120 & $10 / 06 / 94$ & 1513 & 798.9 & 1401.6 & 1887.8 & 823.4 & 1411.3 & 1833.3 & 44.1 & 32.1 & 40.6 \\
\hline USGS 120 & $10 / 06 / 94$ & 1528 & 785.9 & 1377.8 & 1821.6 & & & & & & \\
\hline USGS 120 & $10 / 06 / 94$ & 1532 & 885.4 & 1454.5 & 1790.4 & & & & & & \\
\hline$\overline{\text { USGS } 120}$ & $07 / 17 / 96$ & 1033 & 1293.1 & 1484.2 & 3610.2 & 1163.1 & 1513.4 & 3404.3 & 147.6 & 21.1 & 253.6 \\
\hline USGS 120 & $07 / 17 / 96$ & 1040 & 1239.6 & 1522.7 & 3555.8 & & & & & & \\
\hline USGS 120 & $07 / 17 / 96$ & 1044 & 956.7 & 1533.5 & 3047.0 & & & & & & \\
\hline USGS 121 & $10 / 24 / 94$ & 1019 & 381.9 & 12783.1 & 18.1 & 424.3 & 7059.6 & 45.2 & 251.3 & 4207.1 & 19. \\
\hline USGS 121 & $10 / 24 / 94$ & 1027 & 139.9 & 2790.6 & 63.6 & & & & & & \\
\hline USGS 121 & $10 / 24 / 94$ & 1046 & 751.0 & 5605.1 & 54.0 & & & & & & \\
\hline USGS 124 & $07 / 20 / 94$ & 1421 & 116.4 & 1823.4 & 51.0 & 114.2 & 1807.8 & 52.8 & 1.6 & 11.1 & 2. \\
\hline USGS 124 & $07 / 20 / 94$ & 1429 & 112.6 & 1798.2 & 51.4 & & & & & & \\
\hline USGS 124 & $07 / 20 / 94$ & 1437 & 113.7 & 1801.8 & 56.0 & & & & & & \\
\hline USGS 124 & $04 / 20 / 95$ & 0915 & 117.7 & 1813.8 & ERR & 117.4 & 1787.9 & ERR & 0.3 & 25.9 & $\overline{\text { ERF }}$ \\
\hline USGS 124 & $04 / 20 / 95$ & 0925 & 117.0 & 1762.0 & ERR & & & & & & \\
\hline USGS 124 & $04 / 20 / 95$ & 0930 & 119.4 & 1822.6 & 54.0 & & & & & & \\
\hline USGS 124 & $10 / 09 / 96$ & 1135 & 115.2 & 1522.4 & 37.9 & 116.4 & 1587.2 & 40.5 & 1.8 & 47.4 & 1. \\
\hline USGS 124 & $10 / 09 / 96$ & 1143 & 119.0 & 1605.0 & 41.1 & & & & & & \\
\hline USGS 124 & $10 / 09 / 96$ & 1147 & 115.1 & 1634.4 & 42.5 & & & & & & \\
\hline$\overline{\text { USGS } 125}$ & $06 / 06 / 95$ & 1155 & 223.4 & 423.1 & 263.5 & 225.9 & 434.5 & 247.4 & 4.6 & 28.4 & 19.4 \\
\hline USGS 125 & $06 / 16 / 95$ & 1205 & 222.0 & 406.9 & 220.1 & & & & & & \\
\hline USGS 125 & $06 / 16 / 95$ & 1210 & 232.4 & 473.6 & 258.6 & & & & & & \\
\hline USGS 125 & $10 / 11 / 96$ & 1004 & 247.6 & 470.5 & 276.0 & 237.1 & 458.4 & 266.2 & 9.0 & 17.1 & \\
\hline USGS 125 & $10 / 11 / 96$ & 1016 & 225.5 & 470.5 & 263.4 & & & & & & \\
\hline USGS 125 & $10 / 11 / 96$ & 1024 & 238.2 & 434.2 & 259.2 & & & & & & \\
\hline
\end{tabular}


Table 3. Concentration of sulfur hexafluoride $\left(\mathrm{SF}_{6}\right)$ in ground water from the Snake River Plain aquifer in and near at the Idaho National Engineering and Environmental Laboratory.

[Location of wells is shown in figures 1,2 and 3. The volume of water processed is given in liters. STD, standard deviation; fmol/L, femtomole per liter; $\mathrm{HS}$, headspace extraction of $\mathrm{SF}_{6} ; \mathrm{P} \& \mathrm{~T}$, purge and trap extraction of $\mathrm{SF}_{6}$; Field, field processed sample; Lab., laboratory processed sample; ----, not determined]

\begin{tabular}{|c|c|c|c|c|c|c|c|}
\hline $\begin{array}{l}\text { Well } \\
\text { name }\end{array}$ & $\begin{array}{c}\text { Date } \\
\text { sampled }\end{array}$ & $\begin{array}{c}\mathrm{SF}_{6} \\
(\mathrm{fmol} / \mathrm{L})\end{array}$ & $\begin{array}{l}\text { Population } \\
\text { STD }\end{array}$ & $\begin{array}{c}\text { Number of } \\
\text { replicates }\end{array}$ & $\begin{array}{c}\text { Water } \\
\text { volume }\end{array}$ & $\begin{array}{l}\text { Extraction } \\
\text { procedure }\end{array}$ & $\begin{array}{l}\text { Location of } \\
\text { processing }\end{array}$ \\
\hline ANP 6 & $06 / 15 / 95$ & 0.18 & 0.00 & 2 & 4 & $\mathrm{HS}$ & Field \\
\hline ANP 9 & $10 / 14 / 96$ & .59 & --- & 1 & 1 & P\&T & Lab. \\
\hline Arbor Test & $04 / 21 / 95$ & .22 & --- & 1 & 4 & HS & Field \\
\hline Arbor Test & $10 / 10 / 96$ & .61 & --- & 1 & 1 & $P \& T$ & Lab. \\
\hline Atomic City & $10 / 09 / 96$ & .72 & --- & 1 & 1 & P\&T & Lab. \\
\hline EBR I & $10 / 16 / 96$ & .81 & ---- & 1 & 1 & P\&T & Lab. \\
\hline Fire Station 2 & $10 / 16 / 96$ & .06 & ---- & 1 & 1 & P\&T & Lab. \\
\hline INEL 1 WS & $06 / 12 / 95$ & .15 & .01 & 2 & 4 & HS & Field \\
\hline NPR Test & $04 / 17 / 95$ & 2.83 & --- & 1 & 4 & HS & Field \\
\hline NPR Test & $10 / 10 / 96$ & 1.52 & --.- & 1 & 1 & $\mathrm{P} \& \mathrm{~T}$ & Lab. \\
\hline$P \& W 2$ & $10 / 25 / 94$ & .61 & ---- & 1 & 1 & P\&T & Field \\
\hline P\&W 2 & $04 / 19 / 95$ & .61 & ---- & 1 & 4 & HS & Field \\
\hline P\&W 2 & $10 / 15 / 96$ & .46 & --- & 1 & 1 & $\mathrm{P} \& \mathrm{~T}$ & Lab. \\
\hline Site 04 & $10 / 16 / 96$ & .29 & --- & 1 & 1 & P\&T & Lab. \\
\hline Site 14 & $10 / 14 / 96$ & 3.40 & --- & 1 & 1 & P\&T & Lab. \\
\hline Site 17 & $06 / 17 / 95$ & .77 & .01 & 3 & 4 & HS & Field \\
\hline TAN Expl. & $10 / 14 / 96$ & .02 & --- & 1 & 1 & P\&T & Lab. \\
\hline USGS 001 & $10 / 09 / 96$ & .42 & --- & 1 & 1 & P\&T & Lab. \\
\hline USGS 004 & $10 / 24 / 94$ & .49 & ---- & 1 & 1 & P\&T & Field \\
\hline USGS 004 & 04/19/95 & .27 & --- & 1 & 4 & HS & Field \\
\hline USGS 004 & $10 / 15 / 96$ & .23 & --- & 1 & 1 & $P \& T$ & Lab. \\
\hline USGS 005 & $10 / 10 / 96$ & .80 & ---- & 1 & 1 & $\mathrm{P} \& \mathrm{~T}$ & Lab. \\
\hline USGS 007 & $10 / 14 / 96$ & 17.83 & --- & 1 & 1 & P\&T & Lab. \\
\hline USGS 008 & $10 / 08 / 96$ & .73 & .06 & 2 & 1 & P\&T & Lab. \\
\hline USGS 009 & $04 / 20 / 95$ & .30 & ---. & 1 & 4 & HS & Field \\
\hline USGS 009 & $10 / 11 / 96$ & .29 & --- & 1 & 1 & P\&T & Lab. \\
\hline USGS 011 & $04 / 20 / 95$ & .67 & --- & 1 & 4 & HS & Field \\
\hline USGS 011 & $10 / 09 / 96$ & .36 & -.-. & 1 & 1 & P\&T & Lab. \\
\hline USGS 012 & $10 / 27 / 94$ & .42 & --- & 1 & 1 & P\&T & Field \\
\hline USGS 012 & $06 / 14 / 95$ & .11 & .01 & 1 & 4 & HS & Field \\
\hline USGS 014 & $10 / 24 / 94$ & .97 & --- & 1 & 1 & P\&T & Field \\
\hline USGS 014 & $10 / 09 / 96$ & .80 & ---- & 1 & 1 & P\&T & Lab. \\
\hline USGS 015 & $06 / 14 / 95$ & 1.70 & --- & 1 & 4 & HS & Field \\
\hline USGS 017 & $10 / 27 / 94$ & .06 & --- & 1 & 1 & $\mathrm{P} \& \mathrm{~T}$ & Field \\
\hline USGS 017 & $06 / 13 / 95$ & .00 & ---- & 1 & 4 & HS & Field \\
\hline
\end{tabular}


Table 3. Concentration of sulfur hexafluoride $\left(\mathrm{SF}_{6}\right)$ in ground waters from the Snake River Plain aquifer in and near the Idaho National Engineering and Environmental Laboratory--continued

\begin{tabular}{|c|c|c|c|c|c|c|c|}
\hline $\begin{array}{l}\text { Well } \\
\text { name }\end{array}$ & $\begin{array}{c}\text { Date } \\
\text { sampled }\end{array}$ & $\begin{array}{c}\mathrm{SF}_{6} \\
(\mathrm{fmol} / \mathrm{L})\end{array}$ & $\begin{array}{l}\text { Population } \\
\text { STD }\end{array}$ & $\begin{array}{l}\text { Number of } \\
\text { replicates }\end{array}$ & $\begin{array}{c}\text { Water } \\
\text { volume }\end{array}$ & $\begin{array}{l}\text { Extraction } \\
\text { procedure }\end{array}$ & $\begin{array}{l}\text { Location of } \\
\text { processing }\end{array}$ \\
\hline USGS 018 & $07 / 19 / 96$ & 4.04 & 0.00 & 2 & 1 & $\mathrm{P} \& \mathrm{~T}$ & Lab. \\
\hline USGS 019 & $10 / 25 / 94$ & 3.12 & ---- & 1 & 1 & $\mathrm{P} \& \mathrm{~T}$ & Field \\
\hline USGS 019 & $04 / 19 / 95$ & 3.99 & -..- & 1 & 4 & $\mathrm{HS}$ & Field \\
\hline USGS 019 & $10 / 15 / 96$ & 2.28 & --- & 1 & 1 & P\&T & Lab. \\
\hline USGS 022 & $06 / 13 / 95$ & .05 & .00 & 2 & 4 & $\mathrm{HS}$ & Field \\
\hline USGS 023 & $10 / 25 / 94$ & 14.62 & ---- & 1 & 1 & P\&T & Field \\
\hline USGS 023 & $04 / 19 / 95$ & 8.60 & -.-- & 1 & 4 & HS & Field \\
\hline USGS 023 & $10 / 15 / 96$ & 5.21 & ---- & 1 & 1 & P\&T & Lab. \\
\hline USGS 026 & $10 / 15 / 96$ & 13.40 & ---- & 1 & 1 & P\&T & Lab. \\
\hline USGS 027 & $10 / 15 / 96$ & .72 & .07 & 2 & 1 & P\&T & Lab. \\
\hline USGS 029 & $06 / 15 / 95$ & .20 & .03 & 2 & 4 & HS & Field \\
\hline USGS 031 & $06 / 15 / 95$ & .38 & .03 & 2 & 4 & HS & Field \\
\hline USGS 031 & $10 / 15 / 96$ & .94 & .11 & 2 & 1 & $\mathrm{P} \& \mathrm{~T}$ & Lab. \\
\hline USGS 032 & $06 / 15 / 95$ & .12 & ---- & 1 & 4 & HS & Field \\
\hline USGS 083 & $04 / 17 / 95$ & .07 & ---- & 1 & 4 & HS & Field \\
\hline USGS 086 & $10 / 11 / 96$ & .64 & ---- & 1 & 1 & P\&T & Lab. \\
\hline USGS 097 & $06 / 13 / 95$ & .11 & .00 & 2 & 4 & HS & Field \\
\hline USGS 098 & $06 / 12 / 95$ & .13 & .01 & 2 & 4 & HS & Field \\
\hline USGS 099 & $06 / 12 / 95$ & .16 & ---- & 1 & 4 & HS & Field \\
\hline USGS 100 & $04 / 21 / 95$ & .48 & ---- & 1 & 4 & HS & Field \\
\hline USGS 100 & $10 / 10 / 96$ & .28 & ---- & 1 & 1 & $\mathrm{P} \& \mathrm{~T}$ & Lab. \\
\hline USGS 101 & $04 / 21 / 95$ & .21 & .02 & 2 & 4 & HS & Field \\
\hline USGS 101 & $10 / 10 / 96$ & .20 & ---- & 1 & 1 & P\&T & Lab. \\
\hline USGS 102 & $06 / 13 / 95$ & .10 & .00 & 2 & 4 & HS & Field \\
\hline USGS 103 & $04 / 18 / 95$ & .32 & ---- & 1 & 4 & HS & Field \\
\hline USGS 104 & $04 / 18 / 95$ & 1.95 & ---- & 1 & 4 & HS & Field \\
\hline USGS 105 & $04 / 18 / 95$ & .50 & ---- & 1 & 4 & HS & Field \\
\hline USGS 107 & $10 / 09 / 96$ & .57 & .14 & 2 & 1 & P\&T & Lab. \\
\hline USGS 108 & $04 / 18 / 95$ & .29 & .04 & 2 & 4 & HS & Field \\
\hline USGS 109 & $04 / 20 / 95$ & .47 & -.-- & 1 & 4 & HS & Field \\
\hline USGS 109 & $10 / 11 / 96$ & .43 & --- & 1 & 1 & P\&T & Lab. \\
\hline USGS $110 \mathrm{~A}$ & $10 / 09 / 96$ & .43 & --- & 1 & 1 & P\&T & Lab. \\
\hline USGS 121 & $10 / 24 / 94$ & .29 & --- & 1 & 1 & P\&T & Field \\
\hline USGS 124 & $04 / 20 / 95$ & .86 & ---- & 1 & 4 & HS & Field \\
\hline USGS 124 & $10 / 09 / 96$ & .74 & --- & 1 & 1 & $\mathrm{P} \& \mathrm{~T}$ & Lab. \\
\hline USGS 125 & $06 / 16 / 95$ & .13 & .02 & 4 & 4 & HS & Field \\
\hline USGS 125 & $10 / 11 / 96$ & .33 & --- & 1 & 1 & $P \& T$ & Lab. \\
\hline
\end{tabular}


Table 4. Concentration of dissolved gases in ground waters from the Snake River Plain aquifer in and near the Idaho National Engineering and Environmental Laboratory.

[Location of wells shown in figures 1,2 and 3. Oxygen and carbon dioxide concentrations change during storage; the estimated concentrations in the ground water are given in parentheses. See text for details. mg/L, milligrams per liter. Symbols: ---, not known]

\begin{tabular}{|c|c|c|c|c|c|c|c|}
\hline $\begin{array}{l}\text { Well } \\
\text { name }\end{array}$ & $\begin{array}{c}\text { Date } \\
\text { sampled }\end{array}$ & $\begin{array}{c}\text { Methane } \\
(\mathrm{mg} / \mathrm{L})\end{array}$ & $\begin{array}{l}\text { Carbon } \\
\text { dioxide } \\
(\mathrm{mg} / \mathrm{L})\end{array}$ & $\begin{array}{c}\text { Nitrogen } \\
(\mathrm{mg} / \mathrm{L})\end{array}$ & $\begin{array}{l}\text { Oxygen } \\
(\mathrm{mg} / \mathrm{L})\end{array}$ & $\begin{array}{l}\text { Argon } \\
(\mathrm{mg} / \mathrm{L})\end{array}$ & $\begin{array}{l}\text { Number of } \\
\text { replicates }\end{array}$ \\
\hline ANP 6 & $07 / 19 / 96$ & 0.000 & $8.5(7.0)$ & 15.52 & $1.6(4.5)$ & 0.554 & 1 \\
\hline ANP 9 & $10 / 14 / 96$ & .002 & $4.6(3.0)$ & 18.05 & $5.2(8.5)$ & 0.616 & 1 \\
\hline Arbor Test & $04 / 21 / 95$ & .000 & $3.3(2.5)$ & 16.63 & $7.8(9.0)$ & 0.596 & 1 \\
\hline Arbor Test & $10 / 10 / 96$ & .000 & $3.2(2.5)$ & 15.61 & $6.1(8.5)$ & 0.569 & 2 \\
\hline Arco City 4 & $5 / 13 / 97$ & .000 & $5.5(4.5)$ & 18.68 & $6.5(9.5)$ & 0.665 & 2 \\
\hline Area 2 & $07 / 18 / 96$ & .000 & $5.0(3.5)$ & 16.49 & $3.7(6.5)$ & 0.551 & 1 \\
\hline Atomic City & $10 / 09 / 96$ & .000 & $5.9(4.0)$ & 14.59 & $1.6(6.0)$ & 0.540 & 1 \\
\hline Badging Facility & $07 / 16 / 96$ & .000 & $6.6(5.0)$ & 15.15 & $2.3(5.5)$ & 0.568 & 2 \\
\hline Big Springs & $5 / 22 / 97$ & .000 & $18(17)$ & 16.26 & $7.6(9.5)$ & 0.598 & 2 \\
\hline CFA 1 & $07 / 16 / 96$ & .000 & $4.4(4.0)$ & 17.13 & $9.0(9.5)$ & 0.614 & 2 \\
\hline CFA 2 & $07 / 16 / 96$ & .000 & $8.7(7.0)$ & 17.58 & $3.0(6.0)$ & 0.602 & 2 \\
\hline Condie Hot Spr. & $5 / 22 / 97$ & .021 & $52(52)$ & 11.87 & $0.9(0.9)$ & 0.445 & 1 \\
\hline EBR 1 & $10 / 16 / 96$ & .000 & $2.3(1.0)$ & 17.44 & $4.7(8.0)$ & 0.578 & 2 \\
\hline Engberson & $5 / 14 / 97$ & .000 & $14(13)$ & 19.48 & $5.8(8.0)$ & 0.671 & 2 \\
\hline Fire Station 2 & $10 / 16 / 96$ & .000 & $6.9(5.0)$ & 16.09 & $5.1(8.5)$ & 0.590 & 1 \\
\hline IET Disposal & $01 / 06 / 00$ & .000 & $6.5(5.0)$ & 26.75 & $0.3(--)$ & 0.750 & 2 \\
\hline Leo Rogers 1 & 07/17/96 & .000 & $5.9(4.5)$ & 14.82 & $2.3(5.5)$ & 0.557 & 2 \\
\hline Lidy Hot Spring & $5 / 14 / 97$ & .015 & $24(24)$ & 9.39 & $0.5(--)$ & 0.392 & 1 \\
\hline Neville & $5 / 14 / 97$ & .000 & $3.5(3.0)$ & 16.27 & $6.6(9.0)$ & 0.598 & 2 \\
\hline NPR Test & $04 / 17 / 95$ & .003 & $5.7(5.0)$ & 18.40 & $8.3(8.5)$ & 0.645 & 1 \\
\hline NPR Test & $10 / 10 / 96$ & .001 & $4.6(4.0)$ & 17.58 & $6.2(8.5)$ & 0.619 & 2 \\
\hline Pencheri 6 & $5 / 13 / 97$ & .000 & $5.8(5.5)$ & 17.35 & $8.1(9.5)$ & 0.635 & 2 \\
\hline Park Bell & $5 / 21 / 97$ & .003 & $2.7(2.7)$ & 16.46 & $0.0(--)$ & 0.578 & 2 \\
\hline PSTF Test & $10 / 14 / 96$ & .000 & $4.1(3.0)$ & 17.27 & $6.9(9.0)$ & 0.597 & 2 \\
\hline P\&W 2 & $04 / 19 / 95$ & .000 & $4.1(4.0)$ & 16.73 & $9.4(10)$ & 0.636 & 1 \\
\hline P\&W 2 & $10 / 15 / 96$ & .000 & $5.9(4.0)$ & 16.29 & $6.0(10)$ & 0.611 & 1 \\
\hline RWMC M3S & $07 / 22 / 96$ & .000 & $6.7(5.0)$ & 16.91 & $2.4(5.0)$ & 0.583 & 1 \\
\hline RWMC M7S & $07 / 22 / 96$ & .000 & $5.3(5.0)$ & 16.08 & $2.4(5.0)$ & 0.562 & 1 \\
\hline Site 04 & $10 / 16 / 96$ & .000 & $5.1(4.0)$ & 16.49 & $7.0(8.0)$ & 0.589 & 2 \\
\hline Site 09 & $7 / 22 / 96$ & .000 & $6.1(5.0)$ & 15.97 & $0.7(3.5)$ & 0.585 & 1 \\
\hline Site 14 & $10 / 14 / 96$ & .000 & $4.0(4.0)$ & 16.50 & $4.9(6.5)$ & 0.592 & 2 \\
\hline Site 19 & $07 / 16 / 96$ & .000 & $8.3(7.0)$ & 14.90 & $2.1(5.5)$ & 0.537 & 1 \\
\hline Squirrel Cemetery & $5 / 21 / 97$ & .000 & $14(12)$ & 21.40 & $4.2(5.5)$ & 0.720 & 1 \\
\hline TAN Exploration & $10 / 14 / 96$ & .000 & $2.8(2.5)$ & 29.38 & $11(11)$ & 0.934 & 1 \\
\hline USGS 001 & $10 / 09 / 96$ & .002 & $6.4(--)$ & 15.47 & $0.8(--)$ & 0.559 & 1 \\
\hline USGS 002 & $07 / 17 / 96$ & .000 & $8.1(--)$ & 14.85 & $0.2(--)$ & 0.562 & 1 \\
\hline USGS 004 & $04 / 19 / 95$ & .000 & $16(14)$ & 16.81 & $7.0(9.0)$ & 0.615 & 1 \\
\hline USGS 004 & $10 / 15 / 96$ & .000 & $17(15)$ & 16.67 & $3.7(7.0)$ & 0.622 & 1 \\
\hline USGS 005 & $10 / 10 / 96$ & .000 & $5.8(4.0)$ & 16.50 & $2.1(6.0)$ & 0.593 & 1 \\
\hline USGS 006 & $07 / 18 / 96$ & .000 & $4.9(--)$ & 18.43 & $0.0(--)$ & 0.636 & 1 \\
\hline USGS 007 & $10 / 14 / 96$ & .000 & $3.2(3.0)$ & 16.02 & $1.2(4.0)$ & 0.593 & 2 \\
\hline USGS 008 & $10 / 08 / 96$ & .002 & $8.4(---)$ & 17.02 & $0.5(--)$ & 0.602 & 1 \\
\hline USGS 009 & $10 / 11 / 96$ & .000 & $3.8(2.0)$ & 17.22 & $4.7(8.5)$ & 0.619 & 1 \\
\hline
\end{tabular}


Table 4. Concentration of dissolved gases in ground waters from the Snake River Plain aquifer in and near the Idaho National Engineering and Environmental Laboratory-continued

\begin{tabular}{|c|c|c|c|c|c|c|c|}
\hline $\begin{array}{l}\text { Well } \\
\text { name }\end{array}$ & $\begin{array}{c}\text { Date } \\
\text { sampled }\end{array}$ & $\begin{array}{c}\text { Methane } \\
(\mathrm{mg} / \mathrm{L})\end{array}$ & $\begin{array}{l}\text { Carbon } \\
\text { dioxide } \\
(\mathrm{mg} / \mathrm{L})\end{array}$ & $\begin{array}{c}\text { Nitrogen } \\
(\mathrm{mg} / \mathrm{L})\end{array}$ & $\begin{array}{l}\text { Oxygen } \\
(\mathrm{mg} / \mathrm{L})\end{array}$ & $\begin{array}{l}\text { Argon } \\
\text { (mg/L) }\end{array}$ & $\begin{array}{l}\text { Number of } \\
\text { replicates }\end{array}$ \\
\hline USGS 011 & $04 / 20 / 95$ & 0.000 & $3.6(--)$ & 20.14 & $8.1(--)$ & 0.687 & 1 \\
\hline USGS 011 & $10 / 09 / 96$ & Trace & $7.3(--)$ & 15.93 & $0.5(--)$ & 0.583 & 1 \\
\hline USGS 014 & $10 / 09 / 96$ & .001 & $7.6(6.0)$ & 23.31 & $2.7(7.0)$ & 0.679 & 1 \\
\hline USGS 015 & $06 / 14 / 95$ & .000 & $3.6(3.0)$ & 16.88 & $5.5(7.0)$ & 0.636 & 1 \\
\hline USGS 015 & $05 / 13 / 97$ & .000 & $4.3(3.0)$ & 16.81 & $6.0(8.5)$ & 0.629 & 2 \\
\hline USGS 018 & $07 / 19 / 96$ & .000 & $6.2(5.0)$ & 15.12 & $1.5(4.0)$ & 0.561 & 1 \\
\hline USGS 019 & $10 / 15 / 96$ & Trace & $8.5(8.0)$ & 13.74 & $4.6(5.6)$ & 0.526 & 2 \\
\hline USGS 022 & $7 / 18 / 96$ & .000 & $2.8(--)$ & 15.32 & $0.0(--)$ & 0.524 & 1 \\
\hline USGS 023 & $04 / 19 / 95$ & .001 & $5.2(4.0)$ & 14.51 & $6.1(8.0)$ & 0.541 & 1 \\
\hline USGS 023 & $10 / 15 / 96$ & .001 & $6.7(4.0)$ & 14.07 & $3.0(8.0)$ & 0.526 & 1 \\
\hline USGS 026 & $10 / 15 / 96$ & .002 & $7.2(6.0)$ & 16.01 & $3.2(7.0)$ & 0.579 & 1 \\
\hline USGS 027 & $10 / 15 / 96$ & Trace & $5.5(4.0)$ & 17.46 & $1.9(5.0)$ & 0.615 & 1 \\
\hline USGS 029 & $07 / 18 / 96$ & .000 & $7.9(7.0)$ & 16.26 & $1.5(4.0)$ & 0.594 & 1 \\
\hline USGS 031 & $06 / 15 / 95$ & .000 & $4.0(3.5)$ & 16.63 & $7.0(8.0)$ & 0.604 & 1 \\
\hline USGS 031 & $07 / 19 / 96$ & .000 & $7.2(4.0)$ & 15.85 & $1.4(8.0)$ & 0.583 & 1 \\
\hline USGS 032 & $06 / 15 / 95$ & .000 & $4.8(4.0)$ & 15.21 & $7.5(8.0)$ & 0.573 & 1 \\
\hline USGS 032 & $07 / 19 / 96$ & .000 & $10(--)$ & 15.09 & $0.0(--)$ & 0.565 & 1 \\
\hline USGS 036 & $07 / 16 / 96$ & .000 & $8.9(7.0)$ & 15.72 & $2.1(5.0)$ & 0.566 & 1 \\
\hline USGS 082 & $07 / 16 / 96$ & .000 & $8.4(7.0)$ & 19.98 & $1.5(5.0)$ & 0.662 & 1 \\
\hline USGS 083 & $04 / 17 / 95$ & .003 & $3.1(--)$ & 19.42 & $8.3(--)$ & 0.670 & 1 \\
\hline USGS 086 & $10 / 11 / 96$ & .000 & $3.0(--)$ & 24.92 & $8.5(---)$ & 0.818 & 2 \\
\hline USGS 089 & $07 / 17 / 96$ & .000 & $3.0(--)$ & 19.91 & $0.8(--)$ & 0.714 & 2 \\
\hline USGS 097 & $06 / 13 / 95$ & .000 & $7.1(7.0)$ & 16.70 & $8.4(9.0)$ & 0.601 & 1 \\
\hline USGS 098 & $06 / 12 / 95$ & .000 & $4.9(4.5)$ & 18.42 & $9.1(9.5)$ & 0.643 & 1 \\
\hline USGS 099 & $06 / 12 / 95$ & .000 & $6.8(6.0)$ & 16.19 & $8.2(9.0)$ & 0.595 & 1 \\
\hline USGS 100 & $10 / 10 / 96$ & .000 & $5.0(3.0)$ & 15.72 & $3.9(8.0)$ & 0.580 & 1 \\
\hline USGS 101 & $10 / 10 / 96$ & .000 & $3.9(2.0)$ & 15.83 & $4.9(8.0)$ & 0.579 & 1 \\
\hline USGS 102 & $06 / 13 / 95$ & .000 & $6.9(6.0)$ & 17.22 & $8.7(9.0)$ & 0.613 & 1 \\
\hline USGS 103 & $04 / 18 / 95$ & .002 & $4.5(3.0)$ & 15.00 & $6.1(8.0)$ & 0.566 & 1 \\
\hline USGS 103 & $07 / 15 / 96$ & .000 & $5.5(4.5)$ & 15.26 & $1.8(4.0)$ & 0.501 & 1 \\
\hline USGS 104 & $07 / 15 / 96$ & .000 & $8.1(---)$ & 49.61 & $10(--)$ & 1.168 & 1 \\
\hline USGS 107 & $10 / 09 / 96$ & .000 & $7.2(5.0)$ & 14.57 & $1.4(5.0)$ & 0.539 & 1 \\
\hline USGS 108 & $04 / 18 / 95$ & .000 & $3.8(3.0)$ & 15.32 & $8.0(9.0)$ & 0.575 & 1 \\
\hline USGS 109 & $10 / 11 / 96$ & .000 & $4.5(3.0)$ & 16.48 & $5.2(8.5)$ & 0.603 & 1 \\
\hline USGS 110A & $10 / 09 / 96$ & .000 & $7.9(---)$ & 14.68 & $0.0(--)$ & 0.541 & 1 \\
\hline USGS 112 & $07 / 15 / 96$ & .000 & $8.2(6.0)$ & 15.18 & $2.1(5.0)$ & 0.561 & 2 \\
\hline USGS 113 & $07 / 16 / 96$ & .000 & $8.0(5.0)$ & 15.10 & $2.4(5.0)$ & 0.549 & 1 \\
\hline USGS 115 & $07 / 15 / 96$ & .000 & $7.8(6.0)$ & 20.19 & $2.6(6.0)$ & 0.675 & 2 \\
\hline USGS 116 & $07 / 15 / 96$ & .000 & $7.7(6.0)$ & 16.76 & $1.3(4.5)$ & 0.584 & 2 \\
\hline USGS 117 & $07 / 17 / 96$ & .000 & $5.4(---)$ & 18.24 & $0.7(---)$ & 0.622 & 1 \\
\hline USGS 120 & $07 / 17 / 96$ & .000 & $6.7(5.0)$ & 17.12 & $2.1(5.0)$ & 0.599 & 1 \\
\hline USGS 124 & $04 / 20 / 95$ & .001 & $5.0(4.0)$ & 15.84 & $6.9(8.0)$ & 0.590 & 1 \\
\hline USGS 124 & $10 / 09 / 96$ & .001 & $7.5(5.0)$ & 15.82 & $1.2(6.0)$ & 0.575 & 1 \\
\hline USGS 125 & $6 / 16 / 95$ & .000 & $3.3(2.5)$ & 16.60 & $7.8(9.0)$ & 0.599 & 1 \\
\hline USGS 125 & $10 / 11 / 96$ & .000 & $5.3(3.0)$ & 15.88 & 4.1 (8.) & 0.593 & 1 \\
\hline Wagoner Ranch & $5 / 22 / 97$ & .000 & $9.0(8.0)$ & 17.45 & $5.6(8.5)$ & 0.596 & 2 \\
\hline
\end{tabular}

